\author{
UNIVERSIDADE DE SÃO PAULO \\ FACULDADE DE FILOSOFIA, LETRAS E CIÊNCIAS HUMANAS \\ DEPARTAMENTO DE LETRAS MODERNAS \\ PROGRAMA DE PÓS-GRADUAÇÃO EM ESTUDOS LINGUÍSTICOS, LITERÁRIOS E \\ TRADUTOLÓGICOS EM FRANCÊS
}

CHRISTINE JANCZUR

\begin{abstract}
Apresentação de uma tradução comentada da Introdução e da Primeira Parte de Introduction à l'étude de la médecine expérimentale de Claude Bernard: do projeto à realização
\end{abstract}

Versão corrigida

São Paulo

2015 


\author{
UNIVERSIDADE DE SÃO PAULO \\ FACULDADE DE FILOSOFIA, LETRAS E CIÊNCIAS HUMANAS \\ DEPARTAMENTO DE LETRAS MODERNAS \\ PROGRAMA DE PÓS-GRADUAÇÃO EM ESTUDOS LINGUÍSTICOS, LITERÁRIOS E \\ TRADUTOLÓGICOS EM FRANCÊS
}

CHRISTINE JANCZUR

\title{
Apresentação de uma tradução comentada da Introdução e da Primeira Parte de Introduction à l'étude de la médecine expérimentale de Claude Bernard: do projeto à realização
}

\author{
Dissertação apresentada ao Programa de Pós- \\ Graduação em Estudos Linguísticos, Literários e \\ Tradutológicos em Francês do Departamento de Letras \\ Modernas da Faculdade de Filosofia, Letras e Ciências \\ Humanas da Universidade de São Paulo para obtenção \\ do título de Mestre em Letras. \\ Orientadora: Profa. Dra. Adriana Zavaglia
}

São Paulo 


\section{FOLHA DE APROVAÇÃO}

\section{Christine Janczur}

Apresentação de uma tradução comentada da Introdução e da Primeira Parte de Introduction à l'étude de la médecine expérimentale de Claude Bernard: do projeto à realização

Dissertação apresentada ao Programa de PósGraduação em Estudos Linguísticos, Literários e Tradutológicos em Francês do Departamento de Letras Modernas da Faculdade de Filosofia, Letras e Ciências Humanas da Universidade de São Paulo para obtenção

Aprovada em 30/09/2015 do título de Mestre em Letras.

\section{Banca Examinadora}

Profa. Dra. Adriana Zavaglia - orientadora

Instituição: Faculdade de Filosofia, Letras e Ciências Humanas, Universidade de São Paulo (USP)

Assinatura:

Prof. Dr. Hamilton Haddad Junior (Titular)

Instituição: Instituto de Biociências, Universidade de São Paulo (USP)

Assinatura:

Prof. Dr. João Azenha Junior (Titular)

Instituição: Faculdade de Filosofia, Letras e Ciências Humanas, Universidade de São Paulo (USP)

Assinatura:

Profa. Dra. Maria Elice Brzezinski Prestes (Suplente)

Instituição: Instituto de Biociências, Universidade de São Paulo (USP)

Assinatura:

Profa. Dra. Eliane Gouvêa Lousada (Suplente)

Instituição: Faculdade de Filosofia, Letras e Ciências Humanas, Universidade de São Paulo (USP)

Assinatura: 
A meus pais, que há muito tempo viraram estrelas, a quem muito devo pelo que sou. A meu marido e meus filhos, meu presente, meu porto seguro. 


\section{AGRADECIMENTOS}

Em primeiro lugar, aos meus pais. Onde estiverem, devem estar felizes vendo que a filha, que eles ensinaram desde cedo a valorizar os estudos, levou isso a sério e não parou de estudar até hoje. Apesar de sua simplicidade e do pouco estudo formal, foram pessoas cheias de sabedoria, que deram a mim e minhas irmãs, acima de tudo, muito amor e muita vontade de seguir em frente. Serei sempre grata pelo esforço deles para que nós pudéssemos ter uma vida digna, apesar de todas as dificuldades que enfrentaram, o que, sem dúvida permitiu que eu chegasse até aqui.

Ao meu marido Alcir, aos meus filhos Fernando e Julia e à minha nora Juliana que acompanharam tudo de perto, dando apoio, aguentando minhas crises e me incentivando o tempo todo. E que também entenderam e apoiaram uma esposa e mãe que resolveu ficar longe deles, em outro continente, por um tempo que parecia longo, mas que acabou passando muito rápido e valeu muito a pena. Serei eternamente grata pelo seu apoio e compreensão nesse momento tão importante da minha vida, permitindo que eu realizasse um sonho e pudesse buscar contribuições preciosas para o meu trabalho e para a minha vida pessoal.

Às minhas irmãs queridas, Roseli, Viviane, Stella, pelo simples fato de existirem, de serem a família que sempre me deu suporte e apoio, com muito amor, com quem compartilho os valores que aprendi no meu primeiro núcleo familiar.

À minha querida orientadora, Profa. Adriana Zavaglia, por ter acreditado em mim desde o início e por ter aceitado orientar um projeto que pudesse envolver minha outra formação. Sou grata por todos os conselhos e sugestões, pelo apoio que recebi nos momentos mais difíceis, pela compreensão quando precisei aliar este trabalho a outras atividades profissionais, pela amizade e pela minuciosa leitura do meu trabalho, este último, graças à sua enorme competência e à sua seriedade profissional, que me servem de exemplo. Sou grata também pelo seu entusiasmo relacionado ao projeto um tanto diferente que escolhi, pelo interesse que sempre demonstrou pela obra e pela vida de Claude Bernard e também pelas broncas, elogios e risadas que demos juntas em nossos encontros. 
Ao Prof. Hamilton Haddad Junior, por ter sido aquele que me apresentou ao Claude Bernard, por ter me despertado o interesse pelo estudo de sua obra, por ter me alertado para o seu valor histórico, pelas suas observações e valiosas sugestões por ocasião do exame de qualificação e pelo entusiasmo e disponibilidade que sempre demonstrou todas as vezes em que conversamos a respeito de Claude Bernard e de sua obra, incentivando-me na minha empreitada.

À Profa. Eliane Gouvêa Lousada, por ter me recebido em seu grupo de monitores do francês, pelo apoio constante e por valorizar meu trabalho como educadora. Participar desse grupo tem me dado, ao longo destes anos, a preciosa chance de continuar aprendendo e praticando o francês, em meio a pessoas que estimo e respeito. Sua energia e sua seriedade profissional, contribuindo constantemente para a formação de novos professores, sempre despertaram minha admiração. Sua postura também me serve de exemplo, não só profissional, como também pessoal.

À Profa. Heloisa Brito de Albuquerque Costa, por ter me orientado no primeiro semestre do meu percurso de mestrado e, principalmente, por ter compreendido minhas dúvidas quanto ao projeto que eu então desenvolvia e ter me deixado à vontade para que eu pudesse tomar minha decisão, sem qualquer tipo de pressão. Sempre tive a certeza de que ela teria sido uma ótima orientadora e que só não pudemos fazer um trabalho juntas por eu ter me decidido por um projeto diferente daquele que propunha seu grupo de pesquisa.

Sou grata também mais uma vez às professoras Eliane e Heloísa pelas orientações recebidas ao longo da disciplina de Metodologia na pós-graduação, que ajudaram muito na organização deste projeto ainda em seus primórdios e me forneceram os caminhos a seguir, ao dar a ele continuidade.

À Profa. Cristina Moerbeck Casadei Pietraróia, por ter me incentivado desde a graduação a continuar estudando, estimulando-me a encarar mais um projeto de pós-graduação, tantos anos daquele primeiro em Biologia.

Ao Prof. João Azenha Junior, pela criteriosa avaliação de meu trabalho no exame de qualificação e pelas valiosas sugestões que me permitiram dar continuidade ao projeto.

À Profa. Maria Elice Brzezinski Prestes, pela assessoria e pelas contribuições relacionadas à importância da obra de Claude Bernard para a História da Biologia. 
À Carla, por ser a amiga no mestrado em tradução, que me acompanhou ao longo de todo o período de desenvolvimento deste trabalho, por ter sido companheira de idas a congressos aqui e acolá e também por sempre trocar ideias comigo a respeito de todo tipo de atividade ligada à tradução e à nossa vida acadêmica.

À Carol Madruga e à Emily, que me acompanharam ao longo de toda a aventura do curso de Francês, desde as primeiras aulas da graduação até os cursos de pós-graduação, dividindo angústias e alegrias, período durante o qual sempre tive a certeza de que eu poderia contar com elas para o que precisasse.

À Patricia e à Melissa, que embora tenham seguido em outras habilitações, foram companheiras na habilitação de Português desde o primeiro dia de aula da graduação até o fim do longo percurso do bacharelado e que continuam sendo amigas, que não estejamos mais tão próximas no dia-a-dia.

A TODOS os meus colegas monitores do Francês, com quem tive a oportunidade de aprender a ensinar essa língua estrangeira, particularmente àqueles com quem mais tive a chance de trocar informações e que me ajudaram com tantas ideias e com seus materiais didáticos: Simone, Suélen, Priscila, Veresa, Lygia, Jaci, Tereza, Danilo. Eu fiz questão de citar essas pessoas em particular, por terem sido aquelas que mais diretamente me ajudaram nessa tarefa, mas todos, absolutamente todos, têm minha gratidão e minha simpatia, pois sempre tive enorme prazer em trabalhar nesse grupo e espero que ninguém se sinta excluído desta lista.

À Universidade de São Paulo e à Faculdade de Filosofia, Letras e Ciências Humanas, onde tive a oportunidade de desenvolver minha formação e onde pude resgatar minha vida de pesquisadora, atividade que tanto me dá prazer.

À área de Estudos Linguísticos, Literários e Tradutológicos em Francês e a todos os professores que dela fazem parte e que, de alguma maneira, contribuíram para minha formação no francês e para a aventura de continuar aprendendo.

Enfim, a todos que, de alguma forma contribuíram para que eu acreditasse que todo o esforço vale a pena. 
JANCZUR, C. Apresentação de uma tradução comentada da Introdução e da Primeira Parte de Introduction à l'étude de la médecine expérimentale de Claude Bernard: do projeto à realização. 2015. 225f. Dissertação (Mestrado) - Faculdade de Filosofia, Letras e Ciências Humanas da Universidade de São Paulo, São Paulo, 2015.

Neste trabalho, apresentamos uma tradução comentada, do francês para o português, de parte de uma obra clássica de importância científica. O autor escolhido foi o médico e cientista francês Claude Bernard, que, entre os anos de 1843 e 1879, publicou dezenas de livros sobre sua prática como professor de Fisiologia no Collège de France, em Paris. Dentre eles, o escolhido para este trabalho foi Introduction à l'étude de la médecine expérimentale (1865), após análise de um grande número de obras desse autor e contando com a consultoria de especialistas nas áreas de Filosofia e de História da Ciência. O livro que nos serve de corpus é composto por uma Introdução, seguida de três partes: Do raciocínio experimental, $A$ experimentação nos seres vivos e Aplicações do método experimental no estudo dos fenômenos da vida. A proposta de trabalho inclui a tradução da Introdução e da Primeira Parte do livro, trazendo uma série de notas de diferentes tipos, relacionadas tanto ao conteúdo científico quanto a questões de tradução propriamente ditas. A nossa opção de tradução na elaboração dessa proposta foi a de levar o leitor ao encontro do texto original, isto é, em direção ao autor, o que consiste em um procedimento de tradução denominado estrangeirizante (Venuti, 1995), que privilegia o estilo de escrita desse autor, a terminologia por ele utilizada e enfatiza as questões científicas do século XIX por ele abordadas, da maneira como as mesmas se inseriam no contexto da época, em relação ao século XXI.

Palavras-chave: tradução comentada, estrangeirização, tradução científica, história da ciência, francês-português. 


\section{JANCZUR, C. Proposal of an annotated translation of the Introduction and First Part of Introduction à l'étude de la médecine expérimentale by Claude Bernard: from project to realization. 2015. 225f. Thesis (Master) - Faculdade de Filosofia, Letras e Ciências Humanas da Universidade de São Paulo, São Paulo, 2015.}

In this study, we present a translation with commentary (or annotated translation), from French to Portuguese, covering a section of a classic work of scientific importance. The author chosen was the French physician and scientist Claude Bernard, who published dozens of books about his practice as a professor of physiology at the College de France in Paris between 1843 and 1879. Upon consideration of a large number of works by this author and with the experts advice in the fields of Philosophy and History of Science, the book chosen for this work was Introduction à l'étude de la médecine expérimentale (1865). The book that is our corpus consists of an Introduction, followed by three parts: The Experimental Reasoning; Experimentation in Living Beings; Applications of the Experimental Method in the Study of the Phenomena of Life. The proposed work includes the translation of the Introduction and First Part of the book, adding several notes of different types, related both to scientific content and to translation issues. Our choice of translation for the development of this proposal was to take the reader into the original text or to its author, consisting of a translation procedure denominated foreignizing (Venuti, 1995). Therefore, we focused on the author's writing style and terminology, emphasizing the scientific issues in the context of the nineteenth century, compared to the twenty-first century.

Keywords: annotated translation, foreignization, translation science, history of science, frenchportuguese. 


\section{RÉSUMÉ}

JANCZUR, C. Présentation d'une traduction annotée de l'Introduction et de la Première Partie du livre Introduction à l'étude de la médecine expérimentale, de Claude Bernard : du projet à son réalisation. 2015. 225f. Mémoire (Master) - Faculdade de Filosofia, Letras e Ciências Humanas da Universidade de São Paulo, São Paulo, 2015.

Ce mémoire vise à présenter une traduction annotée Français-Portugais d'une partie d'une œuvre classique d'importance scientifique. L'auteur choisi a été le médecin et scientifique français Claude Bernard, qui, entre 1843 et 1879, a publié des dizaines de livres sur sa pratique en tant que professeur de physiologie au Collège de France à Paris. Parmi ses œuvres, a été choisie pour ce travail Introduction à l'Étude de la médecine expérimentale (1865), après l'examen d'un grand nombre d'ouvrages de cet auteur et d'après l'avis d'experts dans les domaines de la Philosophie et de l'Histoire des Sciences. Le livre choisi est composé d'une Introduction, suivie de trois parties: Du Raisonnement Expérimental, De l'Expérimentation chez les Êtres Vivants, Applications de la Méthode Expérimentale à l'Étude des Phénomènes de la Vie. Ce travail propose donc la traduction de l'Introduction et des deux chapitres de la Première Partie du livre, présentant une série de notes diverses, liées soit au contenu scientifique, soit aux problèmes de traduction proprement dits. Notre choix de traduction dans le développement de cette proposition est de mener le lecteur au texte original, c'est-à-dire jusqu'à l'auteur, une procédure de traduction appelée sourcière (Venuti, 1995). Nous avons mis l'accent sur le style d'écriture de cet auteur et sur la terminologie utilisée et insisté sur les questions scientifiques du XIXe siècle, c'est-à-dire la façon dont ces questions s'inséraient dans le contexte de l'époque si on les compare à celles du XXI ${ }^{\mathrm{e}}$ siècle.

Mots-clés: traduction annotée, traduction sourcière, sciences de la traduction, histoire de la science, français-portugais. 
INTRODUÇÃO

\section{CAPÍTULO 1: VIDA E OBRA DE CLAUDE BERNARD}

1.1 Dados biográficos de Claude Bernard 23

1.2 A importância de Claude Bernard para a História da Ciência 33

1.3 Dados bibliográficos de Claude Bernard 56

\section{CAPÍTULO 2: O PROJETO DE TRADUÇÃO: BASES TEÓRICAS}

2.1 Opções de tradução: a dicotomia domesticação x estrangeirização_68

2.2 Tradução como difusão do conhecimento 83

2.3 Tradução científica e terminologia 92

\section{CAPÍTULO 3: TRADUÇÃO COMENTADA}

3.1 Por que tradução comentada 104

3.2 Materiais e Método 109

3.3 Tradução da Introdução do livro e da Parte I: Do raciocínio experimental 
O experimentador que não sabe o que procura não entende o que encontra.

Claude Bernard 


\section{INTRODUÇÃO}

É esse sentimento, essa aspiração em direção ao desconhecido que conduz o homem à pesquisa, mas é preciso que ele não se apresse a tirar conclusões. [...]. A ciência marcha serena a passos lentos e caminha convencida de que chegará. Ela não se atormenta; ela é calma em sua aspiração em direção ao desconhecido.

Claude Bernard

A ideia de realização do projeto de pesquisa que daria origem a esta dissertação surgiu do desejo de trabalhar com um tema ligado à Biologia, área na qual realizei a minha primeira formação profissional, e também às Letras. Existem, porém, muitas obras científicas relevantes e de importância reconhecida escritas em francês nessa área. Desse modo, o primeiro problema enfrentado foi o da escolha de uma obra que atendesse às expectativas, a saber: que tivesse grande importância no cenário científico tanto da Biologia quanto de domínios afins, que não contasse com traduções em português brasileiro e que merecesse ser traduzida por apresentar conteúdo de interesse didático e científico para os dias de hoje, não importando a época em que tivesse sido escrita. Em outras palavras, era necessário buscar uma obra clássica, em francês, que atendesse a interesses diversos e cujas informações fossem relevantes não só para um público de estudantes dessa área do conhecimento, mas também para profissionais de Biologia e de outras áreas afins.

A motivação primeira para o desenvolvimento do presente projeto foi despertada por sugestão de minha orientadora, que foi quem primeiro me mostrou como unir as minhas duas formações, a de Biologia e a de Letras Português/Francês, por meio da tradução de uma obra clássica. Ao começar a trabalhar com um projeto no qual esses conhecimentos poderiam ser reunidos e aproveitados, pude perceber que os conhecimentos de Francês e de Biologia assim combinados podiam colaborar de maneira bastante significativa na compreensão do texto original e da importância do mesmo para as descobertas daquele momento histórico do conhecimento científico. Os conhecimentos na área da Biologia, permitiam, em outras palavras, 
compreender os novos conceitos que esse estudioso lançava naquele momento e que viriam a mudar o olhar sobre aquela disciplina de forma bastante significativa.

Foi assim que, amadurecendo essa ideia e conversando com pessoas envolvidas na área da Biologia, surgiu o nome do médico e fisiologista francês chamado Claude Bernard (1813-1878). Os escritos desse autor têm valor para diferentes áreas do conhecimento, tais como a Biologia, a Medicina, a Filosofia e a História da Ciência, os quais permeiam seu trabalho e se intercomunicam na totalidade de sua obra. As informações encontradas em seus livros, sejam transcrições de aulas, anotações de seus procedimentos em práticas de laboratório ou ainda as propostas de novos conceitos, vêm sempre acompanhadas de reflexões sobre a busca do conhecimento científico e seus procedimentos. Além disso, e também por isso, seus escritos contribuíram para mudar a forma de encarar a ciência e o procedimento de pesquisa científica de sua geração e das subsequentes, desempenhando um importante papel história do conhecimento científico. Podese ainda acrescentar que as reflexões encontradas ao longo de toda a obra de Claude Bernard serviram e ainda servem de base para estudos filosóficos e epistemológicos. Apesar de ter sua importância reconhecida no cenário de estudos da História da Biologia na França, onde sua contribuição é considerada incontestável, nenhum dos livros desse autor foi traduzido para o português do Brasil, não sendo, portanto, acessível a brasileiros em sua própria língua.

O caminho para definir a escolha desse autor foi longo, tendo início no momento em que ficou decidido que o projeto que seria levado adiante seria relacionado à tradução. Como já mencionado, o interesse surgiu pelo fato de eu já ter uma experiência profissional prévia, bem anterior à minha formação na área de Letras. Sou bióloga e, depois de ter trabalhado por mais de duas décadas como professora do Ensino Médio e como revisora de conceitos de Biologia para editoras de livros didáticos, passei a trabalhar com a tradução, do inglês para o português, de documentários científicos para a televisão (Discovery Channel).

A tradução, área ligada às Ciências Humanas, me levou a ingressar em uma nova faculdade para obter uma formação em Letras, quando já era Bacharel e Mestre na área de Genética, em Biologia. Uma vez cursando essa faculdade na Universidade de São Paulo, escolhi como habilitação o francês. Nesse período, cursei disciplinas optativas de tradução, com o intuito de 
entrar em contato com essa área do conhecimento do ponto de vista teórico, para aprimorar o meu trabalho, já que a minha proximidade com a tradução tinha se dado anteriormente apenas pela prática. Além disso, cursei um ano letivo de FLE (Français Langue Étrangère) na Université Lumière Lyon 2, na França, como intercambista. Os cursos em questão eram voltados para a formação de professores de francês como língua estrangeira, o que acabou despertando meu interesse também na área do ensino de língua estrangeira, uma vez que a prática do ensino já fazia parte de meu histórico profissional como bióloga.

Embora ao partir para a França eu estivesse decidida a me dedicar a uma pesquisa na área da tradução do francês, ao retornar, comecei em 2011 a dar aulas de francês nos cursos extracurriculares da Universidade de São Paulo e tive a impressão de que a pesquisa no ensino de francês seria mais adequada para mim, o que me levou a ingressar no Mestrado em Estudos Linguísticos, Literários e Tradutológicos em Francês com um projeto ligado ao Ensino. Porém, quando me vi às voltas com a leitura de textos voltados para essa área, percebi que meu grande desejo de dar aulas não significava necessariamente que eu queria ou que eu precisava pesquisar a didática do ensino de línguas.

Já mestranda, fui novamente para a França com o objetivo de recolher material de diversas bibliotecas e também de adquirir livros para o meu projeto de pesquisa em ensino, que se encontrava então em andamento. Durante esse período e em todas as visitas que fiz a várias bibliotecas $^{1}$ e livrarias, acabei me dando conta de que tudo o que me chamava a atenção tinha a ver com o meu antigo projeto de tradução, anterior à pesquisa na área do ensino. Eu ainda pensava naquela pesquisa em tradução que eu havia deixado para trás e da qual, tudo indicava, eu não havia me desligado por completo.

\footnotetext{
${ }^{1} \mathrm{Na}$ França, os livros de Claude Bernard (coleções raras, em sua maior parte) e os livros de outros autores tratando de sua vida e obra foram consultados nas seguintes bibliotecas: Bibliothèque Municipal de Lyon (http://www.bmIyon.fr/pratique/bibliotheques/bib3Pd.htm), Bibliothèque Universitaire Lyon 1, Université Claude Bernard (http://portaildoc.univ-lyon1.fr/) em várias de suas unidades, a saber, Rockefeller (BU Santé- Faculté de Médecine), -Laennec (Faculté de Medécine), Bibliothèque des Sciences (Gerland) (http://portailsante.univlyon1.fr/bibliotheques-de-lyon1-490366.kjsp?RH=1182847371409), e Bibliothèque du Centre National de la Recherche Scientifique (CNRS) (http://colisciences.in2p3.fr/)
} 
Como acabei ingressando no mestrado na área de ensino de francês, já matriculada e não querendo abandonar por completo aquele projeto anterior, eu e a profa. Adriana decidimos que seria possível fazer a tradução de uma obra clássica paralelamente ao meu trabalho de mestrado. Aceitei aliviada a proposta de levar adiante esse projeto de tradução porque realmente eu não queria abandoná-lo, ainda que não pudesse empreendê-lo como um projeto de mestrado.

O fato de constatar que, após andar por bibliotecas e livrarias, todos os livros que eu tinha comprado e todas as anotações que eu tinha feito nas bibliotecas visitadas só tinham a ver com o meu projeto de tradução com a profa. Adriana me deixou bastante confusa. Ao voltar para o Brasil, tentei ainda levar adiante o projeto de pesquisa na área da didática do ensino de francês, mas, embora fosse interessante, senti que não seria esse o meu caminho. As evidências me mostravam que o trabalho que me daria prazer seria o da tradução de um clássico de Biologia, o mesmo com o qual já havíamos começado a trabalhar e que parecia ser aquele que eu teria condições de desenvolver com mais satisfação.

Por isso, quatro meses após meu ingresso no mestrado em didática do ensino de língua francesa e depois de conversar com as duas professoras envolvidas (a que era então a minha orientadora e a que seria a futura, em função da mudança), alterei meu projeto para um novo projeto de mestrado, desta vez voltado para a tradução de uma obra clássica de Biologia. Foi assim que comecei a desenvolver o projeto de pesquisa cujos resultados ora apresento.

Embora a escolha desse fisiologista francês parecesse bastante promissora, isso ainda não bastava para a elaboração de um projeto; era necessário também eleger, entre todas as suas obras, uma que merecesse prioritariamente uma tradução em português. Numa etapa posterior, tendo tomado conhecimento dos principais títulos por meio de pesquisas realizadas aqui e na França, discutimos essa questão com os especialistas da área de Fisiologia e da História da Ciência, Prof. Dr. Hamilton Haddad e Profa. Dra. Maria Elice Brzezinski Prestes, do Instituto de Biociências da Universidade de São Paulo e da Associação Brasileira de Filosofia e História da Biologia, respectivamente. Primeiramente, elegemos três obras que atendiam às nossas expectativas: Leçons sur les phénomènes de la vie, communs aux animaux et aux végétaux, 18781879, 2 vols., livro que traz as bases do conceito de meio interno em Fisiologia, Cahier de notes 
1850-1860, Paris, Gallimar,1965, obra póstuma, que consiste em um conjunto de anotações e comentários a respeito de sua prática e Introduction à l'étude de la médecine expérimentale, 1865, que traz as bases do método científico na experimentação.

Introduction à l'étude de la médecine expérimentale, de 1865, não era a obra que eu preferia traduzir, uma vez que já havia sido traduzida para o português europeu sob o título Introdução à Medicina Experimental ${ }^{2}$. Após as conversas com os especialistas citados, que mostravam preferir essa obra frente às outras duas, algumas justificativas foram se mostrando pertinentes para a sua escolha.

A primeira delas é a de que a tradução portuguesa apresenta terminologia diferente daquela utilizada no português brasileiro, sendo também desatualizada, já que foi publicada nos anos 1950. Embora essa tradução tenha sido republicada, ela não sofreu, nessas novas edições, qualquer modificação desde sua publicação original (datada de 1959; última edição de 2011 em livro de bolso, pela Edições Europa- América ${ }^{3}$ ). Por esse motivo, pesquisadores e estudantes, não fluentes na leitura em francês, preferem ler as traduções disponíveis em inglês ${ }^{4}$, mas essa não é a condição da maioria, ou seja, nem todos os brasileiros interessados na obra dominam a língua inglesa, o que acaba restringindo o seu acesso à obra.

Outra justificativa para a escolha dessa obra, apesar da existência de uma tradução em português europeu, é a de que ela não traz qualquer tipo de nota, mesmo quando as reflexões do autor, a nosso ver, mereçam ser comentadas ou quando nos pareça pertinente que aspectos diacrônicos em relação à terminologia e à visão científica devam ser apontados e, em certa medida, discutidos.

Por essas razões, chegamos à conclusão de que a escolha desse autor e dessa obra em particular atendiam às nossas expectativas iniciais com relação ao trabalho a ser realizado e às

\footnotetext{
2 BERNARD, Claude. Introdução à medicina experimental. Lisboa: Guimarães Editores, tradução de Maria José Marinho (1959).

${ }^{3}$ http://www.wook.pt/ficha/introducao-ao-estudo-de-medicina-experimental/a/id/10953082

${ }^{4}$ BERNARD, Claude. An Introduction to the Study of Experimental Medicine, 1865. First English translation by Henry Copley Greene published by Macmillan \& Co., Ltd., 1927; reprinted in 1949.
} 
dos especialistas consultados, que representam a comunidade à qual, em grande parte, será dirigida a tradução.

Afirmamos anteriormente que o autor escolhido, e consequentemente sua obra, têm grande importância no cenário científico, o que nos levaria a acreditar que seu nome soasse bastante familiar até mesmo fora dos círculos científicos, como acontece, por exemplo, com Charles Darwin, que propôs as bases do processo de evolução biológica pela seleção natural.

Os trabalhos deste último, publicados na Inglaterra em 1859 no livro chamado On the origin of species, trouxeram informações que logo ganharam o mundo e que foram e até hoje são discutidas (e nem sempre bem compreendidas) não só por cientistas, mas por toda a sociedade em geral, além de se tratar de conteúdo que faz parte das disciplinas ensinadas nas escolas não apenas no nível superior ou universitário, mas também em níveis anteriores.

No que diz respeito à tradução, obras consideradas desse porte interessam a estudiosos do mundo todo e, com o intuito de que sejam acessíveis ao maior número possível de pessoas, elas são traduzidas em várias línguas. Foi assim com o livro de Charles Darwin, que, dentre todas as línguas para as quais foi traduzido, foi alvo também de traduções em língua portuguesa, tanto europeia quanto brasileira. No Brasil, o livro que recebeu o título de A Origem das Espécies, continua a ser reeditado até os dias de hoje, o que confirma a sua importância inegável para o conhecimento atual dos processos biológicos e do estudo da Biologia como um todo.

Parece ser algo natural, portanto, que obras de reconhecida importância para o conhecimento humano (e científico, nesse caso particular) sejam difundidas o máximo possível e sejam traduzidas para várias línguas em todo o mundo, principalmente no mundo globalizado de hoje. No Brasil, esperamos encontrar traduzidas para o português obras que apresentem para o conhecimento científico esse mesmo grau de importância, principalmente para garantir aos estudiosos das ciências, em sua língua materna, o acesso às informações nelas contidas.

No entanto, verificamos que isso não ocorreu com as obras de Claude Bernard, um cientista que foi contemporâneo de Darwin e que contribuiu para mudar a visão da importante área da Fisiologia. Seus livros, recheados de reflexões, contribuíram para mudar a maneira de pensar a atividade científica como busca do conhecimento e influenciaram não apenas a 
Fisiologia, mas também outras áreas do conhecimento, como a Filosofia e a História da Biologia. Claude Bernard produziu, entre os anos de 1843 e 1880, uma obra admiravelmente extensa, que nunca foi traduzida para o português, com exceção apenas da obra por nós escolhida, ainda que a tradução tenha sido realizada para o português europeu. Na França, o mérito da obra deste cientista e pesquisador é reconhecido e ele é tão conhecido e reverenciado em meios que extrapolam os meios científicos quanto Louis Pasteur, de quem foi amigo e com quem compartilhou muitas das suas reflexões e descobertas.

A notoriedade de Claude Bernard mostra-se em pequenos, mas não menos importantes, detalhes: a Universidade de Ciências Médicas de Lyon, por exemplo, cidade em cuja vizinhança ele nasceu, leva seu nome. Estátuas em sua homenagem são encontradas em Paris, diante do local onde ele trabalhou durante a maior parte de sua vida, o Collège de France e também em Lyon, no local onde funcionava anteriormente a Faculdade de Medicina e que hoje pertence à Faculdade de Letras daquela universidade. Voltaremos a abordar este assunto com maior profundidade no capítulo 1 deste trabalho.

Apesar da reconhecida importância da obra desse cientista e do papel que ela representa para a história do conhecimento humano, o português brasileiro nunca foi privilegiado com a tradução de qualquer de seus livros. A tradução de Introduction à l'étude de la médecine expérimentale, única exceção, foi feita em Portugal, o que significa que estudiosos brasileiros só têm acesso à obra completa do cientista em seu original em francês, em português europeu ou, em alguns casos, nas traduções encontradas em inglês ou alemão.

Mais adiante, no capítulo 1, apresentaremos as possíveis razões, dadas por estudiosos da área, pelas quais o nome de Claude Bernard não é tão difundido fora dos meios científicos. Ao longo de toda a sua vida, este estudioso teve como tema central de seu trabalho o funcionamento do organismo humano, seus mecanismos e o fascinante mundo particular que ele encerra, capaz de ter suas próprias leis, independentemente do meio em que ele se encontra. Foi ele quem levantou pela primeira vez essa ideia, a ideia do "meio interno" nos organismos mais complexos, um ambiente capaz de funcionar de forma isolada de tudo o que o rodeia, tornando-os de certa forma independentes do meio que os rodeia, conceito este que contribuiu 
para mudar a visão da Fisiologia e da Medicina a partir dessa época, guardando até hoje seus reflexos.

Com o intuito de decidirmos qual seria a forma mais adequada de propor um projeto que utilizasse uma obra deste autor como corpus, restava fazer uma opção de tradução que julgássemos a mais adequada para o texto em questão, assim como para a finalidade à qual imaginávamos que serviria a tradução por nós proposta.

A importância da obra dentro do contexto científico da época e a relevância desse conhecimento para a compreensão do processo histórico no qual se enquadra esse livro nos dias atuais nos levou a optar por uma tradução que refletisse da melhor maneira possível o que representaram suas reflexões e o lançamento dos novos conceitos que ali aparecem no momento histórico em que foram formulados. Somente assim seria possível entender por que o que ali foi exposto teve tamanha importância para o desenvolvimento científico e por que continua a influenciar o pensamento científico até os dias de hoje, embora a ciência e a busca do conhecimento nessa área tenham mudado muito nesse intervalo, que vai do final do século XIX até os dias de hoje.

Por essa razão, escolhemos localizar a tradução o máximo possível na época em que a obra do autor foi elaborada, conservando a terminologia usada no século XIX e a forma peculiar de escrita científica então praticada, além de tentar imprimir marcas de estilo do autor na tradução e recuperar a imagem da maneira como se encarava a ciência médica na segunda metade do século XIX.

Vale ressaltar também que, em termos de opção de tradução, escolhemos inicialmente privilegiar um tipo específico de público-alvo. Embora o autor e sua obra interessem a várias áreas do conhecimento, como já tivemos a oportunidade de mencionar, resolvemos, em um primeiro momento, dirigir nossa tradução mais particularmente ao leitor estudante de Biologia/Fisiologia e de História da Biologia. Isso nos levou a propor, ao longo do processo tradutório, muitas notas com um certo caráter pedagógico, explicando e contextualizando o que é ali exposto pelo autor do século XIX. 
É claro que, por se inserir primordialmente em um projeto de tradução, nossas notas trazem também comentários ligados especificamente ao processo tradutório, esclarecendo opções de tradução de termos específicos ou de questões terminológicas da língua de especialidades ligada à Biologia. No final do processo, finalmente nos demos conta de que esta obra não pode ser limitada a um único tipo de leitor ou de público-alvo, pois é uma obra que ultrapassa esses limites. Sua forma de escrever, seu estilo e suas reflexões resultam em um texto que apresenta fundamentos metodológicos que se prestam não só às disciplinas científicas ligadas à Biologia, mas a qualquer tipo de procedimento científico de qualquer outro tipo de ciência, inclusive das ciências humanas. Desse modo, o público alvo se expandiu para o contexto de outros saberes. Mais adiante, no capítulo 3 (item 3.2), trataremos mais especificamente deste ponto.

A apresentação do presente trabalho foi estruturada em três capítulos, cujos conteúdos são apresentados resumidamente a seguir.

O capítulo 1 divide-se em três itens. No primeiro deles, uma biografia de Claude Bernard é apresentada, a fim de que tomemos conhecimento de contexto histórico, profissional e pessoal no qual ele se inseria. O segundo item apresenta a importância de seu trabalho, tanto para a época em que ele foi produzido como nos dias de hoje, em diferentes áreas do conhecimento como a Biologia e a Filosofia. O terceiro item traz a bibliografia de Claude Bernard, com uma relação de todas as obras publicadas por esse autor e suas respectivas datas.

O capítulo 2 apresenta a fundamentação teórica concernente à teoria da tradução, e também se divide em três itens. No primeiro, discutimos os conceitos de domesticação versus estrangeirização, a fim de justificar nossa escolha de tradução pela estrangeirização. O segundo item mostra o papel da tradução na difusão do conhecimento científico, centrando nossa atenção no conhecimento científico, do qual trata nosso trabalho. $O$ terceiro item apresenta a fundamentação teórica relacionada à terminologia, uma vez que o texto científico se encontra estreitamente relacionado a esta área da tradução, que apresenta termos específicos de uma área do conhecimento. 
No capítulo 3 abordamos inicialmente o conceito de tradução comentada, explicando em seguida quais foram os materiais utilizados para a confeç̧ão deste trabalho e qual foi a metodologia por nós utilizada. Finalizando este capítulo, apresentamos a nossa proposta de tradução para a Introdução e para a primeira parte do livro Introduction à l'étude de la médecine expérimentale, de Claude Bernard. As considerações finais e as referências bibliográficas encerram o presente trabalho. 


\section{CAPÍTULO 1 - VIDA E OBRA DE CLAUDE BERNARD}

É o que pensamos já saber que nos impede de aprender.

Claude Bernard

\section{1. Dados biográficos de Claude Bernard ${ }^{5}$}

Claude Bernard nasceu no dia 12 de julho de 1813 em um pequeno vilarejo próximo de Lyon chamado Saint-Julien (vizinho de Villefranche-sur-Saône), de uma modesta família de produtores de vinho. Nessa região vinícola, seus pais, Pierre François Bernard e Jeanne Saulnier, tinham uma pequena propriedade que ele conservou até sua morte e para onde ele voltava a cada outono, para acompanhar as colheitas, e onde frequentemente se refugiava para pensar e escrever. Foi também ali que ele permaneceu durante os anos em que esteve doente, a fim de restabelecer a saúde no ambiente acolhedor de sua infância.

Mirko Grmek, médico e pesquisador croata naturalizado francês e um dos maiores estudiosos da vida e da obra de Claude Bernard, acredita que foi graças à sua origem no ambiente do campo que Bernard teve e manteve, desde sua infância e ao longo de toda a sua vida, um estreito contato com a natureza, conservando assim o deslumbramento diante dela e de seus mistérios, os quais se esforçou por desvendar (GRMEK, 1997:17). Marie-Aymée Marduel (2006), na biografia por ela compilada, confirma o amor que ele cultivava pelo campo e pelo seu local de nascimento, por suas próprias palavras, numa carta ao amigo Ernest Renan:

Eu vivo no Beaujolais [região vinícola] diante do Dombes [região conhecida como a dos mil lagos, rica em fauna e flora]. Tenho os Alpes por horizonte, cujos cimos brancos eu vislumbro quando o céu está claro... Minha casa, ainda que situada no alto de uma colina, é como um ninho de verdura, graças a um

\footnotetext{
${ }^{5}$ Em comemoração ao bicentenário de seu nascimento, a Université Claude Bernard, Lyon 1 produziu, como parte de suas apresentações, um vídeo com uma animação contando a história desse cientista em três minutos. Esse vídeo pode ser acessado em http://claudebernard2013.univ-lyon1.fr/ Acesso em 22/02/2015

${ }^{6}$ Uma biografia bastante completa e detalhada pode ser encontrada em um site britânico (com versão também em francês), inteiramente dedicado a Claude Bernard: http://www.claude-bernard.co.uk/page24.htm Acesso em $\underline{22 / 02 / 2015}$
} 
pequeno bosque que a sombreia pelo lado esquerdo e a um pomar à esquerda, coisa muito rara em uma região onde se retira até os arbustos para plantar o vinho. (MARDUEL, 2006, p.12, tradução nossa).

Todos os anos, ele voltava para acompanhar a vindima (a colheita das uvas para a produção anual de vinho), cuidando ele mesmo não só desta, como também da venda do vinho produzido, tendo certa vez afirmado: "Durante o dia eu visito os vindimadores... são essas ocupações familiares no meio onde nasci que sempre me dão prazer. " (MARDUEL, 2006, p.12, tradução nossa).

Em outra biografia, escrita por Odile Nguyen-Schoendorff (2009), realizada de uma forma interessante, como se se tratasse de uma autobiografia póstuma, a autora retrata esse mesmo sentimento de Claude Bernard pela sua terra natal, por meio das seguintes palavras, ditas como se o próprio Claude Bernard as declarasse:

Passei meus dias entre as vinhas, numa casa modesta, no alto de uma colina, cuja vista - os vinhedos a perder de vista - ficou gravada no fundo do meu coração. Entre Paris e minha vila natal, nunca me desligarei de minhas raízes camponesas nem do meu amor pela natureza. (NGUYEN-SCHOENDORFF, 2009, p.10, tradução nossa).

Foi no pequeno vilarejo onde nasceu que o futuro pesquisador fez seus estudos primários, com o cura de sua paróquia, aprendendo principalmente o latim. Mais tarde, ele foi estudar no colégio de jesuítas do vilarejo vizinho, Villefranche-sur-Saône, e depois no colégio real de Thoissey (na mesma região), nos quais recebeu uma instrução mais humanista.

Ao completar 19 anos, o jovem Claude Bernard foi trabalhar como aprendiz do apoticário 7 Louis-Joseph-Marie Millet, numa farmácia de Vaise, subúrbio de Lyon. Ali, eram produzidos medicamentos chamados de miraculosos, para todos os tipos de males, a partir de restos de todo tipo de drogas encontradas na farmácia. Esse procedimento desonesto e um tanto charlatão de

\footnotetext{
7 O mesmo que o atual farmacêutico: o termo apoticário foi substituído por farmacêutico por Luís XIV https://books.google.com.br/books?id=aq9KBQAAQBAJ\&pg=PA15\&lpg=PA15\&dq=apotic\%C3\%A1rio\&source=bl\&o ts=WWG6A-7mxB\&sig=ymKBIBa0Az-JNpwTZAXo9th163o\&hl=pt-BR\&sa=X\&ei=SflVL2 BqmIsQTk IKQBg\&ved=0CEQQ6AEWCA\#v=onepage\& $q=$ apotic\%C3\%A1rio\&f=false
} 
seu mestre, ainda que fundamentado em crenças da época, fez o ainda jovem aprendiz começar a duvidar dos métodos e da farmacopeia (conjunto de informações a respeito dos medicamentos, seu uso e sua nomenclatura) da época. Isso o deixou bastante desanimado e também intrigado, pois não concordava com aquilo que, no entender de seu mestre, tratava-se de um tipo de ciência.

Decepcionado, o jovem aprendiz passava longas horas escondido nos fundos da farmácia escrevendo peças de teatro, uma de suas paixões e, até aquele momento, seu principal objetivo de vida. Seu sonho era tornar-se um grande dramaturgo, sendo o seu emprego na farmácia encarado apenas como um meio de sobrevivência. À noite, ele ia ao teatro de Lyon acompanhar as peças que estavam em cartaz. Depois de algum tempo, tendo descoberto essa prática, Millet o despediu, dizendo que ele demonstrava mais interesse pelo teatro que pelo trabalho. Assim, o jovem deixou o emprego na farmácia para se dedicar ao sonho de ser escritor.

Tendo obtido sucesso local com um primeiro escrito apresentado no teatro intitulado Rose du Rhône, ele resolveu escrever um drama heroico em cinco atos, ao qual deu o título de Artur de Bretanha. Com esta última obra na bagagem, ele partiu para Paris com o intuito de realizar o sonho de lá desenvolver uma carreira literária. Mas seus sonhos desmoronaram logo após sua chegada. Ao submetê-la à apreciação do grande crítico da época, Saint-Marc Girardin, dele ouviu que a melhor coisa a fazer seria encontrar uma outra profissão para ganhar a vida. Sabendo que ele já tinha trabalhado como assistente de um apoticário, ele teria lhe dito: "Você já trabalhou com a farmácia, então faça medicina e guarde a literatura para suas horas de lazer" (MARDUEL, 2006, p.6, tradução nossa).

Esse episódio o fez abandonar definitivamente o sonho das letras, o que o levou a se voltar novamente para o caminho das ciências. Hoje entendemos que suas qualidades de escritor acabaram por se mostrar extremamente importantes para a produção de todo o material científico que ele viria a escrever, o que ele fez com grande qualidade literária e também pedagógica. A sua facilidade para produzir textos resultou em obras científicas com linguagem extremamente clara e de fácil compreensão, mesmo quando tratavam de conceitos bastante inéditos ou de procedimentos experimentais complexos. 
Nas obras que reúnem as lições de cursos que ele ministrava, os conteúdos são apresentados em linguagem acessível não só ao pesquisador da época, como também aos alunos que cursavam suas disciplinas. As dúvidas e reflexões que ele coloca, contestando as práticas realizadas na época, são feitas com uma linguagem clara e, de certa forma, sedutora.

Tendo renunciado à carreira literária, Claude Bernard passou com grande dificuldade pelo exame nacional francês que precede o ingresso ao ensino superior (baccalauréat) e resolveu se inscrever no curso de medicina, em Paris, o que aconteceu em 1834, aos 21 anos. Seus anos de estudo na faculdade de medicina também não foram muito brilhantes e nada poderia ainda indicar ou prever o grande gênio que iria eclodir em alguns anos.

Tudo começou a mudar quando ele encontrou, em 1839, o grande professor François Magendie $^{8}$, de quem se tornou auxiliar para as aulas práticas de Anatomia e de Fisiologia. Muito mais do que ao clínico, o jovem Claude Bernard ligou-se às atividades de fisiologista e de experimentador de seu grande mestre, um verdadeiro pioneiro nessa área, fato esse que despertou sua atenção para a prática que faria a diferença na sua vida profissional e, consequentemente, em toda a obra que ele viria a produzir. Foi no ano de 1841 que Claude Bernard se tornou preparador das aulas de medicina de seu mestre, no Collège de France, descobrindo assim sua verdadeira vocação: a experimentação em Fisiologia.

O aprendiz logo se sentiu fascinado pelos métodos de experimentação desenvolvidos por seu mestre, sentimento assim traduzido na (auto) biografia um tanto romanceada proposta por (Nguyen-Schoendorff, 2009): “esse mestre [Magendie] é alguém que faz despertar a inteligência, cheio de audácia na experimentação fisiológica. Sua paixão é contagiosa. Eu seguirei seu caminho" (NGUYEN-SCHOENDORFF, 2009, p.16, tradução nossa).

Com esse mestre, o então aprendiz descobriu os métodos das dissecções e vivissecções, esta última prática sendo então considerada "o principal meio de ter acesso a descobertas originais e pessoais, ao mesmo tempo que objeto de escândalo" (NGUYEN-SCHOENDORFF, 2009, p.16, tradução nossa). A vivissecção era prática original, pois, ao contrário dos experimentos com

\footnotetext{
${ }^{8}$ François Magendie, médico e fisiologista francês, nasceu em Bordeaux, em 6 de outubro de 1783 e morreu em Paris, em 7 de outubro de 1855. http://www2.biusante.parisdescartes.fr/bio/?cle=572 Acesso em 22/02/2015
} 
cadáveres, esta prática baseava-se na realização de experimentos com animais vivos. Isto, se por um lado permitia observar os organismos em pleno funcionamento (algo extremamente importante para o entendimento dos mecanismos internos do organismo), por outro lado escandalizava a sociedade em geral, que a considerava uma prática cruel, razão pela qual foi combatida ferrenhamente por sociedades protetoras de animais da época (uma delas, fundada pela própria esposa de Claude Bernard). Embora os animais não fossem mortos nos procedimentos, mas sim operados, recuperando-se posteriormente das intervenções a que eram submetidos e por mais que Claude Bernard tentasse convencer as pessoas de que os benefícios obtidos a partir disso para o entendimento de doenças e sua cura eras inestimáveis, a polêmica persistiu porão longo de toda a sua vida.

Foi também com Magendie que ele aprendeu a duvidar das doutrinas aceitas na época. Na verdade, essa era uma das questões que mais o intrigava nas suas dúvidas e reflexões sobre a prática médica da época. Ele não entendia por que numerosos tratamentos (como a sangria, por exemplo) continuavam a ser utilizados sem qualquer outro fundamento a não ser a rotina. "Ah - dizia ele - essas boas e velhas teorias, solidamente assentadas sobre séculos de ineficácia" (NGUYEN-SCHOENDORFF, 2009, p.15, tradução nossa).

Grmek (1997, p.19) endossa a ideia de que Bernard foi além daquilo que aprendeu com Magendie, afirmando que ele "conseguiu ultrapassar o empirismo e o ceticismo de seu mestre e criar, primeiro por sua maneira de trabalhar e depois pela reflexão, um método particularmente fecundo de investigação dos seres vivos".

Embora tenha obtido o título de doutor em medicina, o que lhe permitiria atuar como clínico, Claude Bernard jamais chegou a clinicar, dedicando-se, durante toda a sua vida, às aulas e à pesquisa científica. Foi a partir de sua tese de doutorado que ele inaugurou uma longa série de trabalhos sobre a digestão, a fisiologia dos açúcares no organismo e as funções do sistema nervoso.

Grmek (1997, p.19) acredita que sua tese de doutorado sobre o papel do suco gástrico representou e representa um trabalho útil tanto para a medicina quanto para a ciência pura. No 
entanto, após tentar o exame da agregação ${ }^{9}$ e de ser preterido em favor de outro candidato, Bernard, resignado, decidiu abandonar a pesquisa científica, contentando-se em clinicar como médico de família no vilarejo onde nasceu.

Mas um novo fato o fez mudar de ideia, levando-o de volta ao seu desejo de fazer pesquisa científica. Para conseguir dinheiro para essa atividade, já que sua condição financeira era precária, ele contou com o dote de Françoise-Marie Martin (conhecida como Fanny), filha de um abastado médico parisiense, num casamento arranjado por seu amigo, o químico Pelouze ${ }^{10}$, no ano de 1845.

Dessa união nasceram dois filhos, que morreram ainda bebês, e duas filhas. Estas, anos mais tarde uniram-se à mãe contra o pai por não entenderem a razão de seus experimentos científicos e julgarem que o único objetivo do seu trabalho era submeter animais, como cães e coelhos, aos maus tratos durante suas pesquisas. De qualquer forma, ao contrário de sua mãe, elas tiveram após a morte dela um bom relacionamento com o pai, com o qual mantiveram contato até a sua morte. Não tendo se casado, as filhas de Claude Bernard, Jeanne-Henriette e Marie-Louise, não deixaram descendentes. Não tendo netos, os únicos descendentes do pesquisador são os sobrinhos-netos, netos de sua irmã mais nova.

Claude Bernard e sua esposa Fanny nunca foram felizes no casamento e, por isso, ele muitas vezes se isolava em sua antiga morada de infância, em busca de paz e de sossego para suas reflexões. Em agosto de 1870, o casal se separou oficialmente e, naquele momento, as filhas tomaram o partido da mãe, deixando o pai sozinho no auge de sua glória profissional. Nessa época, ele conheceu Madame Raffalovitch, filha de um banqueiro russo que havia imigrado para a França. Era uma mulher culta, que falava oito línguas; e sua personalidade interessante, aliada à beleza e qualidades morais de boa mãe e esposa, acabaram fazendo dela uma boa amiga, a

\footnotetext{
${ }^{9}$ No sistema educacional francês, o exame de agregação é uma prova bastante competitiva para professores de ensino superior, com número de vagas limitado. O número de candidatos aprovados nesse concurso é bastante pequeno, razão pela qual o status conferido àquele que possui esse título é bastante elevado. Para entender melhor o funcionamento do sistema francês e como esse título se relaciona a outros que podem ser obtidos na titulação acadêmica daquele país, ver http://emaberto.inep.gov.br/index.php/emaberto/article/viewFile/966/869

10 Jules Théophile Pelouze (1807-1867), químico na Universidade de Lille e depois no Collège de France. Biografia disponível em http://www2.biusante.parisdescartes.fr/bio/?cle=17807 Acesso em 22/02/2015.
} 
quem Claude Bernard escreveu perto de quinhentas cartas, sobre os mais variados assuntos. Todas elas foram legadas por ela à Biblioteca de Ciências e estão hoje publicadas em duas obras: “Cartas parisienses" e “Cartas à Madame R" (MARDUEL, 2006, p. 9-10). As cartas por ela escrita, no entanto, foram todas destruídas pela própria autora.

Tendo continuado a pesquisa científica, já nesse início de carreira ele chegou a algumas descobertas importantes em suas pesquisas sobre os aspectos químicos e o controle nervoso da digestão gástrica, passando então a ser considerado, segundo Grmek (1977, p.20), um dos melhores fisiologistas do seu tempo.

Foi também nessa época que ele fez seus primeiros experimentos sobre o curare ${ }^{11}$ (graças a uma seta indígena trazida da América do Sul por um amigo) e também que descobriu o papel da bile na digestão ${ }^{12}$ e estudou a função dos nervos cranianos $^{13}$ e a inervação das cordas vocais. Além disso, ele ainda estudou nesse período o mecanismo da intoxicação pelo monóxido de

\footnotetext{
${ }^{11}$ Curare: sustância extraída de plantas do gênero Strychnos, utilizada por índios sul americanos para envenenar as pontas de suas flechas. Devido ao seu efeito sobre o sistema nervoso, causando paralisia muscular, pode ser atualmente utilizado em combinação com agentes anestésicos (REY, 1999, p.194).

O curare é uma mistura de alcaloides de ocorrência natural encontrados em várias plantas da América do Sul e utilizados como veneno de flechas por índios sul-americanos. Em um experimento que ficou famoso, Claude Bernard mostrou em 1856 que o "curare" causa paralisia muscular, pois impede que os impulsos nervosos que caminham pela fibra muscular atinjam o músculo, o qual se torna incapaz de responder ao estímulo recebido (Rang \& Dale, 2012, p. 164)

O grupo de fármacos conhecidos como fármacos curariformes pode impedir a passagem dos impulsos da terminação nervosa para o músculo. $O$ efeito do curare sobre os músculos causa paralisia muscular devido à incapacidade das junções entre nervos e músculos transmitirem sinais suficientes das fibras nervosas para as fibras musculares. (Hall \& Guyton, 2011, p. 90-91).

${ }^{12}$ A bile é uma secreção digestiva produzida no fígado e armazenada na vesícula biliar. Ela tem duas importantes funções. A primeira está ligada à digestão e à absorção de gorduras. Os ácidos biliares nela contidos: (1) agem como um detergente, reduzindo as grandes partículas de gordura dos alimentos a muitas partículas diminutas, cujas superfícies são atacadas pelas enzimas digestivas secretadas pelo pâncreas e (2) ajudam a absorção dos produtos finais da digestão das gorduras, isto é, favorecem a passagem das moléculas resultantes da digestão das gorduras através da parede do tubo digestivo, a qual deve ser transposta para que tais substâncias cheguem a seus locais de atuação dentro do organismo. Em segundo lugar, a bile serve como meio de excreção de diversos produtos do sangue, incluindo a bilirrubina, produto final da destruição da hemoglobina, e do colesterol em excesso, que são assim eliminados do organismo (HALL \& GUYTON, 2011, p. 825).

${ }^{13}$ Os nervos cranianos correspondem a 12 pares de nervos que partem do tronco do encéfalo, na região da cabeça e que têm a função de receber estímulos que são levados à essa região (nervos sensitivos) e também comandar respostas musculares (nervos motores). Eles desempenham funções ligadas ao olfato, visão, paladar, mastigação, secreção de saliva, audição, movimentação da língua, entre outras (DRAKE, VOGL \& MITCHELL, 2012, p.807; 848-9).
} 
carbono $^{14}$ e as funções do pâncreas ${ }^{15}$, embora ainda procedesse utilizando técnicas já conhecidas e consagradas pelos seus antecessores, sem ter ainda começado a questionar os procedimentos experimentais que eram utilizados até então.

Em 1847, ele foi nomeado suplente do professor Magendie no Collège de France e, a partir de 1852, como seu velho mestre se afastou, foram confiados ao discípulo sua cadeira e seu laboratório. Em 1853, o então professor auxiliar e pesquisador finalmente obteve o título de doutor em zoologia na Sorbonne, após brilhante exposição sobre a função do fígado, até então desconhecida (GRMEK, 1997, p.21). Nesse estudo ele descreveu o importante papel do fígado em liberar glicose no sangue, fazendo uso da reserva da mesma na forma de glicogênio nos intervalos entre refeições, quando a taxa de glicose necessária para a produção de energia pelo organismo começa a cair. Antes desse estudo, se imaginava que apenas os vegetais seriam capazes de produzir glicose e que toda a glicose que era utilizada no organismo humano era aquela que viria diretamente da alimentação. Isso obrigaria o indivíduo a ficar consumindo a glicose constantemente para suprir as necessidades energéticas do organismo. O que Claude Bernard explicou, em última análise e simplificando bastante suas descobertas, foi como e por que era possível a um indivíduo sobreviver em períodos de jejum ou mesmo nos intervalos entre refeições quando a glicose não está sendo fornecida continuamente ao organismo, graças ao papel do fígado de armazená-la e de lança-la na corrente sanguínea quando necessário.

Em 1854, Claude Bernard se tornou o titular da cadeira de medicina no Collège de France e em 1855 substituiu seu antigo mestre Magendie, que finalmente se aposentou do trabalho de pesquisa na instituição parisiense. Sua rotina de trabalho continuava intensa e ele gozou de ótima saúde até 1865, quando contraiu uma forma branda de cólera, durante uma epidemia em Paris. A fim de tentar se recuperar, ele partiu para seu refúgio em Saint-Julien e, como foi obrigado a

\footnotetext{
${ }^{14}$ O monóxido de carbono é tóxico pois se combina de forma estável com a hemoglobina, o que impede que a mesma desempenhe sua função de transportar o oxigênio para os tecidos, levando à morte por asfixia (REY, 1999, 518).

${ }^{15}$ O pâncreas é uma glândula mista que atua na digestão, produzindo as enzimas responsáveis pela digestão de açúcares, proteínas e gorduras. Além disso, produz os hormônios insulina e glucagon, que regulam a quantidade de açúcar presente no sangue. O primeiro, faz com que a glicose absorvida após uma refeição seja armazenada no fígado na forma de glicogênio. O segundo, faz o processo inverso, desdobrando o glicogênio em glicose, nos intervalos entre as refeições, quando a quantidade de glicose no sangue começa a cair (HALL \& GUYTON, 2011, p.987).
} 
permanecer lá por um longo período até apresentar alguma melhora, ele aproveitou sua estada para escrever. Foi nesse período de retiro do trabalho no laboratório que ele escreveu o livro que se tornaria sua principal obra: Introdução ao Estudo da Medicina Experimental ${ }^{16}$.

A partir desse episódio, sua saúde nunca mais se restabeleceu completamente. A doença deixou como sequela a enterite crônica, que o deixava bastante debilitado. Ele passou a sofrer também de um resfriado que não conseguia curar (segundo alguns, devido ao ambiente insalubre do laboratório onde trabalhava), além de reumatismo e dores de cabeça terríveis das quais sofreu pelo resto de sua vida. Embora tenha retornado a Paris, ele voltou a Saint-Julien no outro seguinte e lá permaneceu por mais três meses (MARDUEL, 2006, p.13).

Devido aos problemas de saúde, Claude Bernard começou a passar longas temporadas afastado de Paris, refugiando-se em Saint-Julien. Em 1871, quando passava ali uma longa temporada de seis meses, recebeu uma carta de encorajamento de Pasteur, desejando sua melhora e incentivando-o a voltar ao seu importante trabalho, tanto no laboratório quanto nas aulas. Esses dois cientistas eram amigos e cultivavam uma admiração recíproca. Certa vez, disse Pasteur a respeito de Bernard:

A distinção de sua pessoa, a beleza nobre de sua fisionomia revela uma grande doçura, de beleza amável, sedutora ao primeiro encontro: nenhum pedantismo, nenhum tique de sábio, uma simplicidade arcaica, a mais natural conversação, o mais distante de qualquer afetação, mas o mais rico em ideias justas e profundas, eis alguns dos méritos exteriores do Senhor Claude Bernard (MARDUEL, 2006, p.16, tradução nossa).

Grande parte da obra de Claude Bernard foi produzida a partir das lições que ele escreveu durante todo o período em que atuou como professor no Collège de France. Em 1868 ele se demitiu da Sorbonne, deixando sua cadeira para Paul Bert ${ }^{17}$, seu aluno e seguidor, indo se instalar

\footnotetext{
${ }^{16}$ BERNARD, Claude. Introduction à l'étude de la médecine expérimentale- Paris : Édition Flammarion (2008) 1ạ éd., J. B. Baillière et fils, 1865.

${ }^{17}$ Paul Bert, fisiologista francês, nasceu em Auxerre em 1833 e morreu em Hanói, em 1886. Licenciado em direito, doutor em ciências naturais e medicina, foi professor de Fisiologia e sucedeu a Claude Bernard, tendo tido também carreira política, como ministro da instrução pública. Disponível em http://www2.biusante.parisdescartes.fr/bio/?cle=1853 Acesso em 22/02/2015
} 
no Museu de História Natural de Paris, na cadeira de Fisiologia Geral, onde continuou a escrever a respeito de suas aulas e também de suas reflexões sobre a prática experimental.

No fim de sua vida, segundo Grmek (1977, p.28-9), Claude Bernard recebeu um grande número de homenagens. Tornou-se comandante da Legião de Honra e foi nomeado presidente da Sociedade de Biologia em 1867. Em 1869, foi eleito membro da Academia Francesa, na cadeira de Flourens, também fisiologista. Nesse mesmo ano, foi nomeado senador do Império por Napoleão III e presidente da Academia de Ciências. Em 1872, tornou-se presidente da Associação Francesa para o Avanço da Ciência e, em 1876, comissário da Exposição Mundial de Paris.

Ainda segundo Grmek (1977, p.29), Claude Bernard amenizou seus últimos anos difíceis devido à doença passando longas temporadas em Saint-Julien e desfrutando, após o fim de seu casamento, da amizade com Marie Sarah-Raffalovitch, com quem trocou muitas cartas, nas quais deixa aflorar sua sensibilidade de poeta. Morreu em sua casa em Paris, em frente ao Collège de France, em 11 de fevereiro de 1878, vítima de uma afecção renal, aos 65 anos de idade. Ele recebeu honras nacionais em seu funeral, homenagem reservada até então apenas a chefes políticos e a militares.

Entre as homenagens póstumas que recebeu, uma delas foi um busto em mármore numa praça de Saint-Julien, sua cidade natal. Em Paris, uma estátua em bronze produzida pelo escultor parisiense Eugène Guillaume foi colocada diante do Collège de France, local onde ele trabalhou e atuou como professor durante a maior parte de sua vida e que se localiza também diante da casa onde ele morou. Essa estátua foi levada pelos alemães durante a ocupação e foi derretida. Mais tarde, após o término da guerra, ela foi substituída por uma reprodução em pedra, que se encontra até hoje no local. Uma terceira estátua foi feita pelo escultor lionês Pierre Aubert, e colocada no pátio de honra da antiga Faculdade de Medicina de Lyon (hoje Faculdade de Letras), no Quai Claude Bernard. Esta teve melhor sorte durante a ocupação alemã: foi escondida no subsolo da faculdade e recolocada em seu lugar após o fim da guerra (MARDUEL, 2006, p.25-26).

Graças a Charles Mérieux, que comprou a pequena casa onde Claude Bernard nasceu e também a casa ao lado, onde ele vinha descansar após ter se mudado para Paris, o local foi transformado no Museu Claude Bernard, Saint-Julien-en-Beaujolais. Além de ser um museu 
histórico, onde se encontram objetos que lembram sua vida e sua obra, o museu guarda também uma biblioteca com livros publicados e manuscritos e anotações do pesquisador, que marcaram a história do conhecimento científico e que introduziram a Fisiologia Experimental, como uma disciplina independente, no rol das disciplinas biológicas.

\subsection{A importância de Claude Bernard para a História da Ciência}

A obra de Claude Bernard é bastante extensa e foi produzida ao longo de toda uma vida. Ela inclui não somente as lições que ele ministrou durante toda sua vida como professor de Fisiologia, todas publicadas em livros, como também outros livros que trazem reflexões sobre seus procedimentos de experimentação. Não podemos esquecer que é preciso, além disso, levarse em conta tudo o que ele escreveu na forma de anotações soltas, a maior parte delas organizadas mais tarde pelo médico croata naturalizado francês Mirko Grmek (1924-2000), após terem ficado esquecidas durante muito tempo após a sua morte, no laboratório onde ele trabalhava e onde ministrava suas aulas. O que foi de fato publicado inicialmente nos livros que constam de sua bibliografia não é senão uma pequena parcela de tudo o que ele realmente produziu ao longo de toda a sua vida.

Foi Grmek quem criou um catálogo de todos os manuscritos de Claude Bernard conservados no Collège de France e quem, tendo se interessado a partir de então por esse autor, a ele dedicou sua tese de doutorado ${ }^{18}$. Posteriormente, Grmek publicou outros trabalhos a respeito desse pesquisador do século XIX, tornando-se um dos maiores especialistas sobre sua vida e sobre a sua obra. Grande parte das informações aqui compiladas a respeito da importância de tudo o que foi produzido por Claude Bernard se baseou em informações contidas no livro chamado Le Legs de Claude Bernard (O Legado de Claude Bernard) ${ }^{19}$, que trata desse assunto com bastante profundidade.

\footnotetext{
${ }^{18} \mathrm{Cf}$ dados biográficos disponíveis em http://www.persee.fr/web/revues/home/prescript/article/rhs 015141052000 num 5332101 Acesso em 23/02/2015.

${ }^{19}$ GRMEK, Mirko- Le Legs de Claude Bernard- Paris : Librairie Arthème Fayard, 1997.
} 
Dando conta da extensão da obra de Claude Bernard na França, é preciso ressaltar que seus livros foram publicados entre os anos de 1843 e 1878, sendo o primeiro título, Recherches anatomiques et physiologiques sur la corde du tympan, pour servir à l'histoire de l'hémiplégie faciale $^{20}$ ( Pesquisas Anatômicas e Fisiológicas Sobre a Corda do Tímpano para servir à História da Hemiplegia Facial) e o último, em dois volumes, cuja primeira parte foi publicada pouco após sua morte, intitulado Leçons sur les phénomènes de la vie, communs aux animaux et aux végétaux ${ }^{21}$ (Lições sobre os Fenômenos da Vida, Comuns aos Animais e aos Vegetais). Cerca de nove títulos foram ainda publicados postumamente, sendo o último deles o Cahier de Notes $^{22}$ (Caderno de Notas), em 1965.

Parte desses livros, como já mencionado no início deste capítulo, tratam da apresentação de novos conceitos, como é o caso de Introduction à l'étude de la médecine expérimentale ${ }^{23}$. Eles também podem tratar do registro de suas aulas de Fisiologia no Collège de France, caso em que estão incluídos todos aqueles cujo título se inicia por Leçons (Lições), como Leçons sur les propriétés physiologiques et les altérations pathologiques des liquides de l'organisme ${ }^{24}$ (Lições Sobre as Propriedades Fisiológicas e as Alterações Patológicas dos Líquidos do Organismo). Complementando a bibliografia desse autor, encontramos também discursos proferidos em diversas sociedades da época, entre os quais, o discurso de posse na Académie Française e também cartas e notas e reflexões sobre seu trabalho, uma parte delas encontradas no Cahier de Notes, publicação póstuma acima citada, e outras mantidas em arquivos do Collège de France, catalogadas muito anos após sua morte.

Ao estudar uma obra produzida ao longo de tantos anos, também é preciso levar-se em conta a cronologia, pois é possível verificar, a partir de suas anotações, que os pensamentos e/ou descobertas apresentados por Claude Bernard foram se modificando por meio de um longo

\footnotetext{
${ }^{20}$ BERNARD, C. Recherches anatomiques et physiologiques sur la carde du tympan, pour servir à l'histoire de I'hémiplégie faciale, Paris, Bourgogne et Martinet, 1843, 32 p.

${ }^{21}$ BERNARD, $C$-Leçons sur les phénomènes de la vie, communs aux animaux et aux végétaux, Paris : Baillière, 1878-1879, 2 vol.

22 BERNARD, C. Cahier de notes 1850-1860, présenté et commenté par Mirko Grmek, Paris : Gallimard, 1965.

${ }^{23}$ BERNARD, C. -Introduction à l'étude de la médecine expérimentale, Paris, Baillière, 1865, 400 p.

${ }^{24}$ BERNARD, C. -Leçons sur les propriétés physiologiques et les altérations pathologiques des liquides de l'organisme, Paris : Baillière, 1859, 2 vol.
} 
processo que culminou com as importantes conceituações e conclusões, às quais ele somente chegou após um processo de evolução do seu pensamento e graças ao seu amadurecimento como pesquisador nesse período.

Desta forma, podemos observar que um mesmo conceito, como por exemplo o de "meio interno", aparece em diferentes anotações, em diferentes épocas, sendo inúmeras vezes repensado e reformulado, até que se afirme de forma definitiva. Não que o termo em si tivesse sido estabelecido no princípio e tivesse mudado várias vezes ao longo do tempo, mas sim, que é possível identificar ao longo de toda a obra desse autor os momentos em que ele vai sugerindo as ideias que resultariam no referido conceito, mesmo quando ele ainda não tinha conseguido dar a ele um nome ou ainda não tivesse claro para si mesmo do que se tratava exatamente. É como se acompanhássemos, ao longo da obra de uma vida, a evolução de seu pensamento, até chegar ao conceito definitivo. Grmek (1997) enfatiza assim a importância desse aspecto cronológico na análise dos trabalhos de Claude Bernard:

A prodigiosa fluidez de seu pensamento, pronto a se adaptar ao conhecimento de cada fato novo, seu hábito de revisar sem cessar as teorias, mesmo as mais aceitas, nos obrigam a levar cuidadosamente em conta a cronologia exata de cada ideia, de cada evento (GRMEK, 1997, p.11, tradução nossa).

Uma passagem interessante a esse respeito, apontada por Grmek (1997, p.11), apresenta o próprio Claude Bernard comentando o fato de os críticos tentarem colocá-lo em contradição com ele mesmo, opondo conclusões de teorias novas com as teorias provisórias de trabalhos precedentes, o que indica que eles poderiam não compreender muito bem as condições do desenvolvimento científico. Ele tinha plena consciência de que poderia mudar suas conclusões diante de novos fatos, algo que o tornava bastante diferente dos pesquisadores da época e da maneira de se pensar, de maneira geral, naquela época.

Muito se diz a respeito de sua mente sempre aberta a novidades e de sua capacidade de duvidar sempre, mesmo de teorias muito bem estabelecidas e bastante aceitas. As palavras de Grmek, ao apresentar a proposta de seu texto a respeito do fisiologista, traduzem esse traço da personalidade do pesquisador que era Bernard: 
Lucidez extraordinária! Como se Claude Bernard já soubesse como tantos médicos, biógrafos e historiadores iriam apresentar suas teorias em blocos, sem se preocupar com sua evolução. Foi indo na contramão desse procedimento habitual que decidi mostrar a lenta elaboração teórica, as hesitações, os encadeamentos conceituais, as vicissitudes do trabalho experimental que marcaram o caminho de Bernard por períodos sucessivos de exploração e de falsas rotas, de grandes descobertas, de discussões e de querelas científicas e, finalmente, de generalização conceitual (GRMEK, 1997, p. 12, tradução nossa).

Tratando-se, como vimos, de um autor com obra tão complexa, podemos voltar a fazer uma pergunta a respeito deste assunto já levantado na Introdução deste trabalho: "Por que o nome de Claude Bernard não soa tão familiar a todos quanto o de Pasteur, seu amigo e contemporâneo? ". Segundo Jean Rostand (1955, p.55), embora seu nome domine a Fisiologia francesa, isso se deve ao fato de não existir em sua obra nenhuma descoberta que tenha causado um impacto imediato, que tenha chocado a imaginação do grande público por suas aplicações imediatas e benéficas. Mas ele enfatiza que isso não diminui de forma alguma sua importância.

Grmek (1997) julga que a obra de Claude Bernard, "tanto por suas descobertas como pela criação de novos conceitos, constitui o fundamento da Fisiologia Experimental de nossa época" (GRMEK, 1997, p.15, tradução nossa). De fato, em relação à declaração de Grmek, é importante levar em conta o fato de que provavelmente tudo o que resultou dos estudos de Claude Bernard ao longo de toda a sua vida foi, na verdade, resultado e consequência de seus esforços para dar à Fisiologia o status de uma disciplina independente. Ao criar a "Fisiologia Experimental", ele pretendia criar uma disciplina com suas próprias leis, fato este que evidencia claramente a influência do positivismo de Comte ${ }^{25}$, movimento que estava em evidência nessa época. Embora

\footnotetext{
${ }^{25}$ Augusto Comte (1798-1857) é o fundador do positivismo, um movimento filosófico e político bastante difundido na segunda metade do século XIX. Trata-se de um movimento bastante complexo, mas que podemos entender de forma bastante simplificada, a fim de compreender a importância que teve para a obra de Claude Bernard, como uma corrente de pensamento que se opõe ao espírito teológico e metafísico, segundo a qual o conhecimento científico poderia ser obtido pela descoberta de leis gerais que regem os fenômenos da natureza. Comte acreditava que este procedimento poderia ser aplicado à Matemática, à Física, à Química, à Biologia e à Sociologia. Para informações mais aprofundadas a esse respeito, sugerimos consulta à Stanford Encyclopedia of Phylosoph, disponivel em: http://plato.stanford.edu/entries/comte/\#Con

Outros dados a respeito da corrente do positivismo e sua relação com o método experimental podem ser encontradas em LAVILLE, C, e DIONNE, J. A construção do saber. Porto Alegre: Artmed; Belo Horizonte: Editora UFMG, 1999, p. 27-28.
} 
Claude Bernard compartilhasse das ideias desse filósofo da ciência, ele tinha também críticas, segundo Dutra (2001, p. 63-64) "nada simpáticas", pois ele não aprovava a sua tentativa de estabelecer os limites da ciência (em relação às questões teológicas e/ou filosóficas) pelo fato de ele não ser um cientista.

O que se constata é que existem aspectos da obra de Comte com os quais Bernard concorda e outros dos quais ele discorda. Dutra (2001, p.118) aponta qual é o principal ponto de discordância entre os dois estudiosos, ao dizer:

Assim, a grande diferença entre Bernard e Comte a respeito da evolução natural do espírito humano é que, para este, o estágio positivo supera definitivamente os outros anteriores, o teológico e o metafísico, enquanto que, para Bernard, o homem será sempre metafísico e teólogo, isto é, ele sempre dará lugar ao sentimento e à razão, e a ciência só pode, pelo emprego do método experimental, procurar fazer o melhor uso possível disso.

Vemos aqui que Bernard, embora aceite a ideia do positivismo de que a natureza é governada por leis que devem ser desvendadas pelos cientistas, ele não exclui totalmente, assim como Comte, a questão metafísica. Para Bernard, no estudo das leis que regem os organismos vivos, existem aquelas que podem ser determinadas e outras que fogem ao alcance de nossa compreensão. Por esta razão, Bernard procurou, a partir de sua obra, determinar os limites da Fisiologia Experimental.

A questão dos limites que devem ser impostos a essa nova disciplina, cuja criação estava sendo proposta por Bernard, é discutida de forma bastante clara por Caponi (2001). Basicamente e de forma muito simplificada, o que se observa nos trabalhos de Claude Bernard é a tentativa de estabelecer uma metodologia de experimentação para as ciências biológicas, isto é, que possa ser aplicada a seres vivos, da mesma forma que existem procedimentos para desvendar leis na física ou na química.

No entanto, seres vivos nem sempre mostram comportamentos que se encaixam em leis precisas, e a isso, nosso fisiologista dá o nome de "espontaneidade dos seres vivos", que os diferencia da matéria bruta. A saída encontrada por ele foi sugerir que existem as causas primeiras e as causas próximas dos fenômenos, sendo que apenas as causas próximas são 
passíveis de serem estudadas na forma de leis, enquanto as causas primeiras fogem à nossa compreensão. Assim, a metodologia experimental por ele proposta seria um procedimento capaz de revelar apenas as causas próximas dos fenômenos naturais e assim, para eles, a ideia do determinismo seria então aplicável.

É interessante notar que nessa busca em aceitar, por um lado, que as ciências dos seres vivos podem ser regidas por leis naturais (como as ciências dos corpos brutos) e, por outro, que seres vivos apresentam certa espontaneidade não regida por leis acaba levando Claude Bernard a elaborar explicações que levaram a propor um dos mais importantes conceitos em ciências biológicas: o do meio interno, que permite ao mesmo tempo certa autonomia aos seres vivos, em relação ao que se passa no meio exterior, e cujas leis e propriedades podem ser desvendadas e estudadas. Discutiremos este conceito com mais detalhes mais adiante neste capítulo. Além disso, com essas reflexões, o estudioso da Fisiologia também aproximava, de certa forma, as ciências naturais das ciências do espírito, como afirma Dutra (2001, p.6).

Podemos constatar, retomando o positivismo, que sua influência está bastante clara em Claude Bernard ao longo de toda a sua obra, evidenciando-se por vezes em alguns trechos, como o final da Primeira Parte de Introduction à l'Étude de la Médecine Expérimental, no qual ele afirma:

Toda a filosofia natural se resume nisto: conhecer a lei dos fenômenos. Todo problema experimental se reduz a isto: prever e guiar os fenômenos. Mas este duplo objetivo não pode estar reunido nos corpos vivos senão por certos princípios especiais de experimentação que nos restam a indicar nos capítulos a seguir. (BERNARD, 2008 (1865), p. 117, grifos do autor, tradução nossa).

Dutra (2001, p.1), compartilha da ideia de que Claude Bernard buscava criar uma nova disciplina, dizendo que ele apresenta um "perfil de fundador, papel que ele assumiu de maneira consciente e decidida, pretendendo lançar os fundamentos da fisiologia experimental". Ainda segundo este autor, o que o pesquisador do século XIX pretendia era colocar a disciplina que ele se esforçava por criar ao lado da Física e da Química, ciências essas que já tinham se consolidado com o caráter do que se pode denominar de ciências empíricas da natureza. 
Segundo Janczur et al (2013, p.382)

Claude Bernard foi provavelmente o principal articulador da fisiologia experimental contemporânea, na qual a investigação fisiológica preocupava-se não com a natureza própria da vida, mas com a determinação experimental dos fenômenos vitais. [...] de acordo com Bernard, ao adotar a postura experimental, o fisiologista deve, como qualquer outro cientista, assumir a regularidade das leis da natureza como condição para o discurso científico.

Visto isto, podemos voltar às explicações que Grmek (1997) tenta encontrar para o fato de que, embora muitas pessoas já tenham ouvido falar de Claude Bernard, a maioria não é capaz de dizer qual foi sua importância ou qual foi sua contribuição para a ciência. Ele acredita que isso se deva a dois fatores: primeiro, porque alguns conceitos que ele criou já são tão familiares hoje que não se pensa mais no seu inventor; segundo, porque outros conceitos são tão complexos que demandam um conhecimento científico mais aprofundado para que sejam compreendidos. Segundo suas palavras, "é preciso um certo esforço para seguir os meandros de seus raciocínios e captar as sutilezas de suas soluções originais, frequentemente inesperadas e sempre muito diversificadas" (GRMEK, 1997, p. 16, tradução nossa).

Ao longo de toda a sua vida, Claude Bernard teve como tema central de seu trabalho principalmente o funcionamento do organismo humano, além de ter também se dedicado ao estudo de outros animais e de plantas. No que diz respeito ao corpo humano, ele pesquisou e tentou encontrar respostas para seus mecanismos e encantou-se com o fascinante mundo particular que ele encerra.

Com relação aos organismos mais complexos, teve grande parte de sua obra dedicada à capacidade dos mesmos de terem suas próprias leis, independentemente do meio em que se encontram, o que o levou a propor um dos mais importantes conceitos da Fisiologia, o do "meio interno", o qual discutiremos um pouco mais adiante, ainda neste item. Dentre suas descobertas e inúmeras contribuições para o entendimento da Fisiologia Humana, podemos citar as descobertas sobre o funcionamento do fígado no processo de glicogenólise (síntese da glicose), o que esclareceu os mecanismos da diabetes, e também os resultados do estudo de substâncias 
que atuam no sistema nervoso, como o curare, ainda hoje usado em combinação com outros fármacos em anestesiologia, apresentado anteriormente no item 1.1 e comentado na NT 11.

O período mais fecundo de pesquisas de Bernard ocorreu logo após seu casamento arranjado, quando, tendo quase desistido do trabalho de pesquisa em laboratório para clinicar em sua cidade natal, ele pôde voltar, graças ao dote recebido, a fazer o que ele mais amava: a experimentação. Nessa época, fez várias pesquisas sobre os aspectos químicos e o controle nervoso da digestão gástrica, o que imediatamente o colocou como um dos melhores fisiologistas do seu tempo (GRMEK, 1997, p. 20).

Foi também nessa época que ele fez experimentos com o curare, já mencionado, veneno extraído da ponta de flechas de nativos da Amazônia trazidas por um amigo, além de ter descoberto o papel da bile; fez ainda pesquisas sobre a inervação das cordas vocais e sobre as funções dos nervos cranianos, pesquisou os mecanismos de intoxicação por monóxido de carbono, estudou a absorção de gorduras no organismo e as funções do pâncreas e constatou a ação inibitória do nervo vago sobre o coração.

Em agosto de 1848, Claude Bernard faria uma das suas principais descobertas, a da glicemia não alimentar e presença do açúcar no fígado, que o levou rapidamente à teoria revolucionária da função de síntese de glicose pelo fígado. Mas por que isso era tão importante? Antes dele, ainda se acreditava no que havia dito Lavoisier, isto é, que todo açúcar encontrado no organismo só poderia vir do alimento ingerido e que este era queimado nos pulmões. ${ }^{26} \mathrm{Em}$ decorrência disso, uma ideia corrente na época era a de que os diabéticos sofriam de uma "afecção nervosa dos pulmões" que thes impedia de queimar o açúcar ingerido, o qual permanecia consequentemente em seus organismos.

\footnotetext{
${ }^{26}$ Lavoisier estudava a produção de calor pelos seres vivos e acreditava que este resultava de uma lenta combustão que ocorria nos pulmões, de onde então o calor produzido seria distribuído para todo o corpo. Nesse processo de combustão, também haveria o consumo de glicose. Por isso havia a ideia corrente de que a glicose obtida no alimento era queimada nos pulmões. De fato, assim se encaminhava a descoberta do processo de respiração celular; no entanto o erro de Lavoisier (que ele mesmo chegou a admitir) foi o de imaginar que tudo aconteceria nos pulmões e não, como hoje sabemos, de maneira difusa, em todas as células do corpo. Os trabalhos originais de Lavoisier podem ser consultados e/ou obtidos em versões digitais em: http://moro.imss.fi.it/lavoisier/main.asp e http://www.lavoisier.cnrs.fr/
} 
Mas Claude Bernard encontrou açúcar no sangue de animais que não tinham ingerido essa substância e que tinham até mesmo permanecido vários dias em jejum. Isso derrubou a ideia de Lavoisier de que o açúcar só poderia vir da alimentação e de que ele seria um tipo de "lixo" do qual o organismo teria que se livrar a qualquer custo. Foi então que Claude Bernard começou a aplicar os ensinamentos de Magendie, que o ensinou a duvidar de teorias já estabelecidas ao deparar-se com um novo fato observado, propondo experimentos para testar suas possíveis explicações. Assim começava a tomar corpo uma metodologia experimental totalmente nova na época, a qual ele iria desenvolver ao longo de anos em seus procedimentos de laboratório, culminando nas reflexões finalmente compiladas no seu livro mais conhecido, Introdução ao Estudo da Medicina Experimental, no qual ele estabelece os fundamentos dessa teoria.

A partir do que ele observou, isto é, que a glicose poderia ser encontrada no organismo de animais em jejum, Claude Bernard perguntou a si mesmo: "será possível que o próprio corpo humano produza a glicose? " Foi então que, a partir de seus experimentos, ele constatou que isso de fato era possível e que o local de produção do açúcar no organismo era o fígado. Com essa atitude, ele ousou enfrentar um dogma da Biologia; e é este o traço de personalidade mais admirado nesse pesquisador: a capacidade que ele tinha de duvidar de tudo, de ter a mente aberta para todo e qualquer fato, mesmo quando este contrariava algo que ninguém mais colocaria em dúvida. A esse respeito, o próprio Bernard declarou certa vez:

Eu cheguei ao campo científico por vias tortas [ele pretendia ser escritor] e com isso me livrei das regras estabelecidas, lançando-me através de campos em que outros talvez não tivessem ousado. Porém, acredito que, em fisiologia, isso não tenha sido ruim, porque me conduziu a novos caminhos (BERNARD, 1965, p. 128-9, tradução nossa).

Experimentos posteriores levaram ao que hoje sabemos a respeito desse fenômeno, isto é, que o fígado recebe do sangue a glicose excedente que é ingerida (graças à ação da insulina) e a transforma em glicogênio para então reverter esse processo quando necessário (graças à ação de outro hormônio, o glucagon), lançando a glicose no sangue nos períodos de jejum, mesmo que curtos. Na verdade, aí estava a prova de que a glicose não era algo de que o corpo precisasse 
se livrar, mas sim algo que deveria ser importante para ele, a ponto de ser armazenada para ser utilizada quando necessário. A grande importância de ter sido desvendado o metabolismo dos açúcares nessa época foi que isso permitiu elucidar o mecanismo da diabetes, mostrando que a mesma não se tratava de uma afecção nos pulmões.

Segundo Grmek (1997, p.22-3), pode-se observar um período de transição na produção acadêmica de Claude Bernard. Ao longo dos anos 1850-60, ele anotou suas reflexões num caderno, documento este que marca uma mudança de sua atividade científica para sua empreitada filosófica. Ainda segundo esse autor, a reflexão filosófica encontrada a partir de então na obra desse pesquisador não precedeu a prática, mas foi construída gradativamente a partir de então, isto é, essas reflexões "não fundamentam sua prática, mas servem para justificala" (GRMEK, 1997, p. 93).

Assim, o período das grandes descobertas termina nos anos 1850, dando lugar a um período de sínteses magistrais de tudo o que ele observou nos anos precedentes. O Cahier de Notes, publicado postumamente, mostra bem essa transição: "de um lado o trabalho analítico, o frenesi em busca do fato concreto; de outro as generalizações, a meditação sobre os métodos de pesquisa e sobre os princípios das ciências da vida" (GRMEK, 1997, p.23, tradução nossa). A partir dessa época, ele passou a criar novos conceitos que lhe permitiram generalizar os resultados de seus experimentos e assim surgiram os conceitos de "determinismo experimental", "secreção interna”, "meio interno", "circulação local”, "inervação recíproca”, "ações reflexas paralisantes", etc.

Schiller (1967), outro estudioso da obra de Claude Bernard, também reconhece as duas fases distintas na obra científica desse autor. Ele diz:

A obra científica de Claude Bernard se dividiu esquematicamente em dois períodos: o primeiro vai de 1843 a 1851-52, o segundo, dessa data até a sua morte. O primeiro período é aquele da originalidade de suas descobertas. [...] 0 segundo período é o da originalidade do seu pensamento. Ele aprofunda e amplia as descobertas já feitas, mas também formula conceitos fisiológicos inéditos (meio interno, secreção interna), codifica o método experimental e estabelece a fisiologia geral (SCHILLER, 1967, p. 1, tradução nossa). 
Entre todos os conceitos criados por Claude Bernard, talvez o mais importante deles seja o de "meio interno", pelo qual ele mostrou que o que ocorre no interior dos organismos de animais de sangue quente (aves e mamíferos) é algo que mostra uma grande independência daquilo que ocorre ao seu redor, isto é, no ambiente externo ou cósmico, como Bernard denominava inicialmente. À primeira vista simples e banal, esse conceito modificou a visão a respeito dos organismos vivos e de seu funcionamento, sendo de extrema importância até os dias de hoje.

A construção desse conceito foi algo lento e progressivo e muitas citações podem ser encontradas a esse respeito em suas obras ao longo de muitos anos, mostrando como seu entendimento foi amadurecendo à medida em que ele ia fazendo novas observações, experimentações e descobertas. Ele começou a perceber que, quanto mais complexo era um organismo, maior independência ele apresentava com relação ao meio externo, sendo capaz de manter, por exemplo, a temperatura do corpo e a constituição química dos líquidos internos diferentes daquelas do meio em que se encontrava.

Segundo Grmek (1997, p.45) a expressão “meio interno" foi forjada em 1857 e, pouco a pouco se enriqueceu de novos significados, mas ela já aparecia em seus escritos em 1851, tendo se formado a partir de um enorme conjunto de ideias sobre a existência de um meio animal intermediário, nutritivo e protetor.

Embora a ideia de meio interno tenha sido abordada ao longo de toda a obra Introduction à l'Étude de la Médecine Expérimental, que aqui nos serve de corpus, ela é encontrada de forma estabelecida no trecho do livro Leçons sur le phénomène de la vie communs aux animaux et aux végétaux (Lições Sobre os Fenômenos da Vida Comum aos Animais e aos Vegetais, 1878-9) que se encontra traduzido em Janczur et al (2013). Esse livro foi publicado postumamente por Albert Dastre, em dois volumes, tendo sido apenas o primeiro volume revisado por Bernard, segundo consta, em seu leito de morte. O trecho traduzido é a terceira seção da segunda lição e corresponde aos escritos deste autor em que este importante conceito acima citado aparece de forma mais evidente e completa. É nesta seção que Claude Bernard "enfatiza a importância da 
manutenção da estabilidade do meio interno como condição de vida livre e independente das varições do meio exterior" (Janczur et al, 2013, p. 383).

Esse lento processo de elaboração tem origem no fato de que Claude Bernard se viu diante de um dilema entre o determinismo da natureza e o da liberdade do experimentador. Segundo o determinismo, todos os fatos observáveis são conectados uns aos outros de forma necessária, regidos por leis da natureza que podem ser desvendadas pela experimentação. No entanto, o experimentador é livre para criar condições particulares de um dispositivo experimental, atuando como "o contramestre da natureza", segundo as próprias palavras de Claude Bernard (GRMEK, 1997, p. 94).

Grande parte das reflexões em seu livro Introduction à l'Étude de la Médecine Expérimental (Introdução ao Estudo da Medicina Experimental, 1865) são dedicadas à solução desse dilema, nas quais Bernard discute o papel do experimentador e diferencia os tipos de observação que ele pode fazer, interferindo ou não no processo estudado. Além disso, ele procura diferenciar o determinismo em ciência, do qual ele trata, daquele já conhecido e originalmente proposto pela filosofia. Aí está uma razão pela qual ele é também um autor de interesse para a área da Filosofia, pois suas reflexões vão muito além da simples discussão dos resultados que ele obtinha em seus experimentos; elas tratavam, no fundo, de aspectos ligados à epistemologia.

Enfim, para que Bernard pudesse aplicar nos seres vivos o que a experimentação já aplicava nas pesquisas físico-químicas, onde as rígidas leis que determinam os fenômenos eram descobertas através da experimentação científica, ele precisava admitir tanto o determinismo quanto a liberdade do sujeito que agia na experimentação. É assim que o pesquisador resolve buscar uma solução intermediária, que não era nem materialista, pois não admitia a existência de leis rígidas para regular todos os fenômenos da natureza, nem vitalista, pois não era adepta da corrente que acreditava que a vida provém de uma força vital que não pode ser explicada por nenhuma lei conhecida do homem.

Eram essas as duas correntes que imperavam na época e era a uma delas que as ideias de Claude Bernard tinham que se ajustar para que ele pudesse defender uma metodologia de 
experimentação científica aplicável aos seres vivos. Mas, embora ele não admitisse a teoria do vitalismo, no caso dos seres vivos, era difícil admitir o determinismo sem restrições porque nem tudo o que acontecia nesses organismos parecia ser regido por leis imutáveis. Dessa forma, o dilema que se apresentava ao pesquisador era o de tentar explicar como encarar o mundo vivo de forma que se justificasse a realização de experimentação científica, admitindo que nem sempre seria possível encontrar leis que regessem fenômenos imutáveis, sempre passíveis de repetição. Isso mudou de forma incontestável o cenário da época em relação à pesquisa científica com seres vivos.

Para justificar a aplicação de sua metodologia experimental, Claude Bernard admite, então, o determinismo (não sem antes discutir esse dilema inúmeras vezes ao longo de seus trabalhos) e acaba tentando uma explicação para sua aceitação no livro Introdução ao Estudo da Medicina Experimental (objeto de nosso estudo), com as seguintes palavras:

Existe um determinismo absoluto nas condições de existência dos fenômenos naturais, tanto nos corpos vivos como nos corpos brutos. É preciso admitir como um axioma experimental que nos seres vivos, como nos seres brutos, as condições de existência de todo fenômeno são determinadas de uma maneira absoluta. Isto quer dizer, em outros termos, que a condição de um fenômeno, uma vez conhecida e satisfeita, o fenômeno deve se reproduzir, sempre e necessariamente, ao desejo do experimentador. A negação dessa proposição não seria outra coisa senão a negação da própria ciência (BERNARD, 1865, p. 115-116, tradução nossa).

Mas, ainda assim, em outras passagens e em outras obras, ele mesmo acaba se contradizendo, ora aceitando o determinismo tal e qual aceito para os corpos brutos, outras vezes tentando justificar a existência de certa liberdade entre os seres vivos, que os faziam escapar das leis gerais.

Embora a ideia do vitalismo fosse descartada para Claude Bernard para justificar a validade da sua experimentação, era preciso aceitar a corrente oposta, o determinismo entre os seres vivos, com as ressalvas geradas por suas dúvidas acima expostas. Era preciso compreender que as leis que regem o mundo vivo não poderiam ser tão rígidas quanto aquelas que regem o 
mundo não vivo. A solução para isso, encontrada pelo pesquisador, foi admitir aquilo que ele chamou de "espontaneidade" dos seres vivos, que seria algo real, porém limitado.

Em outras palavras, essa espontaneidade seria diferente de uma total autonomia, embora ele mesmo acabasse muitas vezes caindo em contradição, em diferentes textos, por não conseguir entender, durante muito tempo, até que ponto essa espontaneidade escaparia do determinismo e das leis que regeriam a natureza. Ele precisava encontrar uma explicação para a liberdade que certos organismos apresentavam em relação ao seu meio e por que razão essa liberdade parecia ser tanto maior quanto mais complexo fosse o organismo.

Foi então que, para solucionar esse dilema, surgiu para Claude Bernard uma explicação brilhante: a mediação do meio interno. Segundo Grmek (1997), ele encontrou assim "uma solução original e particularmente elegante [...] a espontaneidade só existe nas relações entre a totalidade do organismo e seu meio externo (GRMEK, 1997, p. 107, tradução nossa).

Nas próprias palavras de Claude Bernard, em sua Introdução ao Estudo da Medicina Experimental, ele afirma:

Consideradas nas condições do meio cósmico geral, as funções do corpo do homem e dos animais superiores nos parecem livres e independentes das condições físico-químicas desse meio, porque é dentro de um meio líquido orgânico interno que se encontram as verdadeiras alterações. O que vemos externamente é apenas o resultado das alterações físico-químicas do meio interno; é lá que os fisiologistas devem estabelecer o real determinismo das funções vitais. As máquinas vivas são criadas e construídas de tal forma que, aperfeiçoando-se, elas se tornam cada vez mais livres do meio cósmico geral (BERNARD, 1865, p. 136-137, tradução nossa).

Claude Bernard criava assim o conceito de meio interno, que ao longo de suas reflexões e ao longo de tantos anos de pesquisa recebeu vários nomes diferentes e foi aludido das mais variadas formas, enquanto ele mesmo procurava dar corpo a essa ideia. Para o experimentador, esse "mundo particular", que era capaz de manter os organismos mais complexos isolados do meio externo, era representado pelo sangue e pelos líquidos do corpo em geral. Grmek (1997) vê assim a importância desse conceito: 
A noção de meio interno é o meio intelectual que permite a Bernard manter o determinismo absoluto da máquina vital e de todos os eventos que se passam no interior do organismo, ao mesmo tempo permitindo ao ser vivo, em toda a sua totalidade, uma certa liberdade, uma espécie de espontaneidade " (GRMEK, 1997, p.108, tradução nossa).

É muito difícil estabelecer com precisão uma data que marque o surgimento do conceito de meio interno, uma vez que o conhecimento cientifico, de maneira geral, passava por grandes mudanças exatamente no período que compreendeu toda a produção cientifica de Claude Bernard. Em grande parte, por conta dessas mudanças, ele teve que ir gradativamente adequando seu pensamentos, suas considerações e suas conclusões. Mas, se ele foi submetido a esse processo de evolução do pensamento científico, ele não deixou também de ser um dos grandes responsáveis por ele. Várias foram as pesquisas e reflexões, ao longo de anos. Já em 1854, ele lançava a ideia de meio interno como objeto da medicina. Segundo Grmek (1997), Bernard considerava que o verdadeiro campo de ação da medicina só poderia ser o meio interno e acrescenta que

toda a ciência dos seres vivos se resume no conhecimento dos modificadores normais, patológicos e terapêuticos dos elementos histológicos. Assim, como regra geral, os modificadores, [segundo Bernard] só agem passando pelo meio interno. Isso abre novas perspectivas para as explicações dos fenômenos tóxicos e para a aplicação prática dos medicamentos (GRMEK, 1997, p. 148-9, tradução nossa).

Muitos anos depois dessas primeiras alusões à existência do meio interno, Bernard, tendo o conceito já quase completamente amadurecido, afirma em 1866:

À medida que os fenômenos da vida se elevam, a organização é mais delicada e se complica, os elementos orgânicos tornam-se mais delicados e não podem mais viver diretamente no meio externo [...] Nos organismos mais elevados e à medida que a massa aumenta, como os elementos orgânicos não poderiam mais ficar em contato com as influências físico-químicas externas, o meio interno assume importância e se constitui sob a forma de um líquido circulante colocando-se incessantemente em contato com os órgãos e os elementos. Este líquido tem o nome de sangue ou liquido nutritivo (BERNARD, 1866 in GRMEK, 1997, p. 146, tradução nossa). 
Suas ideias expostas aqui e ali, em aulas, palestras, discursos e em todos os meios de que ele dispunha, finalmente acabaram, todas elas, convergindo para a noção de meio interno que ele admitiu ter sido por ele criada, o que se pode constatar pela declaração a seguir:

Eu não tenho conhecimento de que alguém tenha distinguido antes de mim um meio externo e um meio interno. Eu acredito ter sido um dos primeiros a propor e a desenvolver essa ideia do sangue considerado como meio interno dos elementos orgânicos (BERNARD, 1867, p.182, tradução nossa).

Bernard usa até mesmo seu discurso de posse na Académie Française (Academia Francesa de Letras), em 1868, para divulgar seus novos conceitos. Grmek (1997, p.57-91) apresenta um longo relato do processo que levou ao discurso final, mostrando que, para chegar àquilo que foi efetivamente proferido, Claude Bernard fez uma grande quantidade de rascunhos, tentando diferentes caminhos e diferentes formas de expor o que ele queria trazer a público. Na verdade, o principal problema era que o que ele tinha a dizer iria se contrapor às ideias vigentes e, por isso, ele sabia que, ao expor suas ideias materialistas para apoiar a experimentação, estaria desagradando aos adeptos do vitalismo, que era então aceito pela maioria. A reação ao discurso foi de fato bastante fria e o que ele disse gerou muita polêmica e muitas críticas, em grande parte contrárias, embora ele tenha recebido algumas críticas favoráveis.

Os novos conceitos propostos por Claude Bernard continuaram a ser gradativamente apresentados por ele, que os discutia também em todas as suas aulas, entre os anos de 1868 a 1876 (GRMEK, 1997, p.170). A certa altura, ele já estava plenamente convencido da originalidade de suas propostas. Em notas manuscritas publicadas em $1937^{27}$, ele diz acreditar que a sua consideração sobre o meio interno é uma das mais fecundas. No último livro por ele publicado em vida, essa ideia já aparece bem estabelecida e ele parece estar bastante convencido de sua validade. Ali se lê:

${ }^{27}$ BERNARD, Claude- Pensées, 1937, in GRMEK, 1997, p.171-2. 
O meio interno que envolve os órgãos, os tecidos, os elementos dos tecidos, não muda; as variações atmosféricas se detêm diante dele, de sorte que que se pode dizer que as condições físicas do meio são constantes para o animal superior; ele está imerso num meio invariável que funciona como uma atmosfera própria num meio cósmico sempre em mudança. É o organismo que se coloca a si próprio numa estufa. Assim, as perpétuas mudanças do meio cósmico não lhe atingem; ele não está preso a elas, ele é livre e independente (BERNARD, 18789 , vol. 2, p.6, tradução nossa).

Ainda nessa mesma obra, a última publicada em vida, lê-se em outro trecho:

A fixidez do meio interno é a condição de vida livre, independente: o mecanismo que permite sua existência é aquele que assegura, no meio interno, a manutenção de todas as condições necessárias à vida dos elementos (BERNARD, 1878-9, vol. 1, p.113-114, tradução nossa).

Grmek (1997) acredita que, com isto, Claude Bernard tenha atingido o apogeu de seu pensamento, pois esse conceito tem a grande importância de apresentar, nada mais, nada menos, do que a condição de vida livre. Posteriormente, esse conceito viria a dar origem à noção atual de "homeostasia", proposta em 1929 por Bradford Cannon (GRMEK, 1997, p. 176; HADDAD, 2012, p. 22). A homeostasia é entendida como a manutenção das condições do meio interno, tais como a temperatura do corpo, o equilíbrio hidroeletrolítico e a composição do sangue. As atividades celulares e as influências externas tendem a modificar esse equilíbrio e, por esta razão inúmeros mecanismos fisiológicos são utilizados para compensar essas eventuais alterações (REY, 1999, p.413)

Para terminar este breve apanhado sobre como o conjunto da obra de Claude Bernard influenciou o pensamento cientifico atual, julgamos pertinente apontar a importância de sua obra mais conhecida e mais discutida nos dias de hoje e que é o objeto de estudo de nosso trabalho: Introduction à l'Étude de la Médecine Expérimental (Introdução ao Estudo da Medicina Experimental).

Segundo Farkas (2003), esse livro é a obra maior de Claude Bernard e trata-se "de um livro de filosofia escrito por um cientista" (FARKAS, 2003, p.16). Essa autora lembra que os cientistas da época em que imperava o positivismo de Comte queriam ignorar as ideias que 
traziam esse livro e que foi apenas Louis Pasteur que o acolheu entusiasticamente, num longo artigo publicado em 1866, um ano após a publicação do livro. Nesse artigo, segundo Farkas (2003), ele teria afirmado: "Nunca se viu nada mais luminoso, mais completo, mais profundo sobre os verdadeiros princípios de uma arte tão difícil quanto a experimentação" (FARKAS, 2003 p. 16).

Schiller (1967) acredita que existiram outras razões para que as ideias propostas tenham recebido imediata aceitação por parte dos cientistas da época. Ele lembra que o conceito de meio interno, por exemplo, foi algo de difícil compreensão por parte dos cientistas da época pelo fato de não haver precursores que já tivessem abordado esse assunto de alguma forma e que, com isso, tivessem dado alguns pontos de apoio ao novo conceito. Não havia uma história anterior a Bernard para apoiar essa ideia que parecia tão estranha, a princípio. Outra dificuldade apontada por esse mesmo autor foi a complexidade e a riqueza do conteúdo da noção de meio interno. Ele afirma que "não há fenômeno fisiológico que, em diversos níveis, escape à influência do meio interno e à sua utilidade como meio de acesso ao estudo do organismo" (SCHILLER, 1967, p.1723, tradução nossa).

O que Claude Bernard propunha no seu livro e que tanto deixava perplexas as mentes científicas da época, no fim das contas, era uma forma de pensar que não separava as ciências do espírito das ciências da natureza. Segundo ele, estas duas deveriam se unir e se confundir na busca das mesmas verdades e a forma de uni-las seria realizada pela Fisiologia. Em seu discurso de posse na Academia Francesa, ele diz:

Não, não pode haver no mundo senão uma única e mesma verdade e essa verdade inteira e absoluta que o homem persegue com tanto ardor só poderá ser o resultado de uma fusão recíproca e de um acordo definitivo de todas as ciências, tenham elas o ponto de partida em nós, no estudo de problemas do espírito humano, ou tenham elas como objetivo a interpretação dos fenômenos da natureza que nos rodeiam [...] (BERNARD, in GRMEK, 1997, p. 82, tradução nossa).

Embora Introduction à l'Étude de la Medécine Expérimental (Introdução ao Estudo da Medicina Experimental) tenha se tornado a obra principal de Claude Bernard, de acordo com 
suas pretensões, como o próprio nome indica, ela deveria fazer parte de uma obra maior, na qual ele pretendia expor sua "filosofia biológica". Essa grande obra seria precedida por uma introdução, na qual ele apresentaria suas reflexões sobre a aplicação do método experimental e em que a noção de meio interno seria o centro de toda a conceptualização de problemas fundamentais da Biologia (GRMEK, 1977, p. 149).

Dando início ao projeto de sua grande obra, Claude Bernard escreveu a Introdução, em seu retiro em Saint-Julien, quando foi obrigado a se afastar de suas funções em Paris por conta do agravamento de sua doença. No entanto, tendo sua doença se agravado e sua saúde se tornado bastante fragilizada, ele acabou não concluindo sua grande obra, que ficou restrita à parte introdutória. Ainda assim, essa introdução se tornou sua obra mais importante e, quando os conceitos ali contidos puderam ser compreendidos, ela deixou maravilhados os fisiologistas que ali encontraram regras da medicina experimental expostas de forma incrivelmente claras, além da resolução de questões que eles consideravam até então insolúveis (HOUSSAY, 1967, p.7).

O livro Introduction à l'Étude de la Medécine Expérimental é composto por uma introdução e três partes distintas. Na introdução, o autor faz uma apresentação da obra e apresenta uma discussão sobre os sistemas de investigação aceitos na época. Na primeira parte (Do Raciocínio Experimental), ele analisa características gerais de um método original, dedicando a maior parte desse raciocínio às discussões sobre a diferença entre observação passiva e observação ativa e sua relação com a experimentação. Nas outras duas partes (Da Experimentação nos Seres Vivos e Aplicações do Método Experimental ao Estudo dos Fenômenos da Vida), ele aplica as regras propostas ao estudo dos seres vivos, fazendo longas considerações sobre a experimentação nos seres vivos, acrescentando algumas discussões filosóficas acerca do papel do estudioso/pesquisador diante das questões da natureza.

Segundo Rostand (1966, p.84), um dos principais méritos dessa obra é a de que ela não é útil apenas para a Biologia, mas para toda a ciência e, ainda mais, para todo domínio onde se exerça o julgamento. Isso porque seu autor não se limita ali a combater o fantasma obstinado da força vital e a afirmar que os fenômenos da matéria viva seguem o mesmo rigor daqueles da matéria bruta, podendo ser previstos com tanta segurança. Ele diz ainda que Claude Bernard não 
se contenta, nesse livro, em lançar as bases de uma medicina racional, fundada na observação e na experiência, mas que ele apresenta as regras de uma verdadeira higiene espiritual (ROSTAND, 1966, p.84-5, tradução nossa).

O próprio Claude Bernard, ao apresentar sua proposta na Introdução do Livro, atribui à obra uma importância que seria efetivamente confirmada no decorrer dos anos posteriores à sua publicação. No início, ele diz:

Não é o caso aqui de entrar no exame de uma definição tão importante como a da medicina experimental. Eu me reservo a tratar dessa questão em outros pontos, com todo o desenvolvimento necessário. Eu me limito aqui a simplesmente dar minha opinião, dizendo o que penso da medicina, que é destinada a ser uma ciência experimental e progressiva; e é precisamente em decorrência de minhas convicções a esse respeito que componho esta obra, com o intuito de dar minha contribuição para o desenvolvimento dessa medicina científica ou experimental (BERNARD [1865], 2008, p.60, tradução nossa) (Grifo do autor).

No entanto, é importante ressaltar que, mesmo compreendendo o valor de sua contribuição, ele se mantinha modesto quanto ao que seria capaz de apresentar, o que pode ser constatado quase no final do livro, quando ele diz:

Eu pretendo ser útil à medicina científica publicando este simples ensaio sobre os princípios da medicina experimental. Na verdade, a medicina é tão vasta, que jamais se pode esperar encontrar um homem capaz de cultivar com proveito todas as suas partes ao mesmo tempo (BERNARD [1865], 2008, p.342, tradução nossa).

De Romo (2007) considera, com relação à obra de Claude Bernard e de sua obra principal da qual ora tratamos, que "seu maior mérito foi sistematizar, sintetizar e expor com clareza filosófica o sentido de sua própria experiência científica e dela fazer um modelo de conduta no laboratório" (DE ROMO, 2007, p.93).

Dutra (2003) considera que as ideias de Claude Bernard, que concebe a Fisiologia como base da Medicina, são inovadoras em relação ao saber médico aceito em seus dias, pois, até então, a Anatomia era a disciplina médica fundamental. Ele o compara, por exemplo, ao seu mais 
proeminente antecessor, Xavier Bichat, considerado até então o mais importante fisiologista na França, cuja visão e cujos procedimentos prevaleciam quando Bernard começou a propor modificações a esse respeito. Dutra (2003) afirma:

De fato, se tomarmos uma figura representativa como Bichat, é a anatomia que surge como o grande empreendimento no que diz respeito aos seres vivos. A fisiologia estava enormemente limitada sob a influência do vitalismo e de sua concepção de que a experimentação com os seres vivos não poderia trazer grande contribuição, já que, como pensavam os vitalistas, ao interferir com os fenômenos vitais, a experimentação destruiria suas características fundamentais. Ora, é a ideia oposta, de que é a experimentação que pode trazer progressos importantes à fisiologia, que caracterizou as obras de Magendie e de Bernard [...] (DUTRA, 2003, p.367).

O vitalismo defendido por Xavier Bichat, como já tivemos oportunidade de apontar, propunha a ideia de que os fenômenos que ocorrem nos seres vivos não poderiam seguir leis rígidas, como as da física ou da química, porque seriam regidos por certas atividades vitais. Como lembra Haddad (2012) ao levantar um breve histórico da História da Fisiologia, um dos primeiros defensores de uma nova abordagem para o estudo da Fisiologia foi Magendie. Ele foi aluno de Bichat, que até então era o fisiologista mais proeminente da época. Posteriormente, Magendie, já discordando de muitas ideias estabelecidas por seu mestre e vigentes na época, tornou-se mestre de Claude Bernard. Ele fazia severas críticas a essas concepções vitalistas, observando que "essas propriedades vitais seriam mais fruto da ignorância dos cientistas que lançavam mão delas quando não conseguiam reduzir um fenômeno biológico a termos físico-químicos, do que propriedades intrínsecas aos seres vivos" (HADDAD, 2012, p. 21).

O próprio Magendie teria anunciado, como observa Haddad (2012), "em tom quase profético": "A Fisiologia está, no momento, precisamente no ponto em que estavam as ciências físicas antes de Newton: ela espera apenas que um gênio de primeira ordem venha para descobrir as leis da força vital do mesmo modo que Newton desvendou as leis da atração" (MAGENDIE, 1816-7 in: HADDAD, 2012, p.21).

A verdade é que "antes de Magendie, muito da Fisiologia tinha sido apenas especulação e inferências a partir da anatomia e da clínica médica. Magendie estabeleceu a importância de 
experimentos diretos em mamíferos vivos, geralmente gatos, cães e coelhos" (GROSS, 1998, p.380, tradução nossa). A técnica por ele empregada utilizava animais vivos (vivissecção) e ela foi ensinada a Bernard, que também a utilizou amplamente em seus experimentos, o que causou enormes polêmicas na época, com reflexos até os dias de hoje.

Ambos acreditavam que a vivissecção era o melhor caminho para encontrar a verdade na medicina. Segundo De Romo (2007, p.92), eles acreditavam que "experimentar in vivo permitia reproduzir os fenômenos nas condições mais próximas do estado natural" e que "a conduta oferecia a possibilidade de manipular os processos a fim de encontrar respostas diante de situações diferentes". Referindo-se a Claude Bernard, essa mesma autora acredita que "sua grande destreza manual lhe permitia operar muito rapidamente numa época em que não existiam os anestésicos atuais" (DE ROMO, 2007, p.92, tradução nossa).

Rostand (1955) também expõe sua opinião sobre a importância dos conceitos trazidos por Bernard, para a Fisiologia, afirmando:

Assim, do ponto de vista metodológico - e esta é uma novidade cuja importância temos dificuldade em avaliar nos dias de hoje - Claude Bernard derrubou a barreira entre as ciências da vida e as ciências da matéria. Para ele, não há dois tipos de ciência, de um lado aquelas em que tudo é preciso, fixo e imutável e, de outro, aquelas que subsistiriam ao vago e ao incerto (ROSTAND, 1955, p. 93, tradução nossa).

Este autor complementa esta ideia dizendo que "Nenhuma ciência é menos ciência que outra" (ROSTAND, 1955, p. 93, tradução nossa). Não há como negar que as descobertas e novos conceitos criados por Claude Bernard estabeleceram grandes modificações no estudo da Biologia e, por isso, ele é considerado uma figura importante na área da Fisiologia, ramo das Ciências Biológicas sobre a qual sua obra teve enorme influência. Rostand (1955) diz a esse respeito:

Da fisiologia, ele fez uma ciência autônoma, separando-a da anatomia e da medicina; ele estabeleceu seu lugar na ordem dos conhecimentos humanos; ele formulou suas leis e precisou os métodos. Ultrapassando os limites da fisiologia propriamente dita, sua influência se estendeu a toda a Biologia. Por ter determinado definitivamente as regras de experimentação aplicadas aos seres vivos, Claude Bernard insuflou nessa disciplina um novo espírito, ele a animou 
de uma força tão ampla que grande parte dos progressos subsequentes que aconteceram deve retornar a ela (ROSTAND, 1955, p. 53, tradução nossa).

Gross (1998) acrescenta que uma prova de que Introduction à l'Étude de la Medécine Expérimental de Claude Bernard representa um marco na História da Biologia é a de que esse livro é reverenciado por cientistas médicos e filósofos. Enfatiza que ele continua a ser editado até os dias de hoje, mesmo na Inglaterra, país de origem de Gross, e ainda é utilizado por todos os tipos de pesquisadores em Biologia, pois é atemporal e porque ali ilustrou vários princípios e práticas da experimentação a partir quase que exclusivamente de sua própria prática em laboratório. (GROSS, 1998, p.381)

Além de sua importância para a Biologia, lembremos que frequentemente se atribui à obra de Claude Bernard uma importância na Filosofia. Clark (1961) diz a esse respeito: "Claude Bernard não se contentou em observar e descrever os fatos; ele procurou explicá-los, a ligá-los por meio de leis. Ele construiu, nesse encadeamento, uma lógica experimental: com isso, ele fez a filosofia" (CLARK, 1961, p.34, tradução nossa).

Por todas as razões acima mencionadas julgamos importante e necessário que parte da obra de Claude Bernard fosse traduzida para o português brasileiro. Dada a importância que tentamos ressaltar da obra Introduction à l'étude de la médecine expérimentale, texto clássico do século XIX que traz as bases da metodologia científica e que ainda não foi traduzido para o português brasileiro, ela foi escolhida para a pesquisa, que deverá ter como resultado uma tradução comentada da Introdução do livro e da Parte 1: Do Raciocínio Experimental. Pretendemos dar continuidade a este projeto, realizando em seguida a tradução comentada do restante da obra, isto é, Parte 2 (Da experimentação nos seres vivos) e Parte 3 (Aplicação do método experimental ao estudo dos fenômenos da vida). 


\section{3. Dados bibliográficos de Claude Bernard}

Claude Bernard escreveu muitos textos, compreendendo livros, artigos, palestras, anotações de pesquisa e também reflexões sobre o trabalho científico e a tarefa de ensinar. Sua obra interessa a estudiosos da ciência, a filósofos e a historiadores da ciência. A relação completa de suas obras é algo que apresenta variações, dependendo do autor que tenta reuni-las. Em sua maioria, os autores que se ocuparam de enumerar as obras de Claude Bernard reúnem nesta listagem apenas os livros principais, deixando de lado uma verdadeira riqueza de informações que se encontram em acervos de museus, compreendendo anotações de aulas, reflexões sobre sua prática, tanto de laboratório quanto de professor, cartas e rascunhos de ilustrações de materiais ligados às suas atividades de pesquisa.

De todas as fontes pesquisadas, a que nos pareceu ser a mais completa foi a publicação do Centre National de la Recherche Scientifique (CNRS - Centro Nacional da Pesquisa Científica na França, o mais importante centro de pesquisas daquele país nessa área). Esse centro dispõe de uma Biblioteca Virtual dedicada exclusivamente a Claude Bernard (La Bibliotèque Virtuelle Claude Bernard) ${ }^{28}$.

Na página dedicada às suas publicações ${ }^{29}$, são indicadas diversas fontes que levaram à lista publicada. Muitas anotações manuscritas, e que aqui foram levadas em conta, encontramse no Museu Claude Bernard, que ocupa hoje a casa onde ele nasceu e que, mesmo no período em que ele morou em Paris, era o local onde ele se refugiava de tempos em tempos. Também são levados em conta os documentos preservados no Collège de France, onde Claude Bernard, durante tantos anos ministrou seus cursos de Fisiologia.

Embora não seja provavelmente ainda completa, é a lista que provavelmente reúne o maior número de obras desse autor e sua transcrição pode ser vista a seguir (Copyright @ CNRS Maison des Sciences de I'Homme Paris Nord - CoLiSciences, 2005):

\footnotetext{
${ }^{28} \mathrm{O}$ endereço eletrônico da Biblioteca Virtual Claude Bernard é http://claudebernard.in2p3.fr/index.php?name=paratexte\&page=presentation

${ }^{29}$ Disponível em http://claudebernard.in2p3.fr/index.php?name=paratexte\&page=bibliographie
} 


\section{3}

-Recherches anatomiques et physiologiques sur la corde du tympan, pour servir à l'histoire de I'hémiplégie faciale, Paris, Bourgogne et Martinet, 1843, 32 p.

-Mémoire sur le suc gastrique et son rôle dans la nutrition, tese, Paris, F. Malteste, 24 p., extrait de la Gazette médicale de Paris.

\section{4}

-Expériences concernant l'influence des nerfs de la huitième paire sur les phénomènes physiques de la digestion, $\mathrm{ADS}^{30}, \mathrm{XVIII}$.

-Recherches physiologiques sur les substances alimentaires, avec Barreswill, ADS, XVIII.

-Sur les phénomènes physiques de la digestion, avec Barreswill, ADS, XIX.

Des matières colorantes chez l'homme, tese de agregação ${ }^{31}$, Paris, 1844, 57 p.

-Recherches expérimentales sur les fonctions du nerf spinal, ou accessoire de Willis, étudié spécialement dans ses rapports avec le pneumo-gastrique, Prix de physiologie expérimentale de l'Académie des Sciences pour 1845, Archives générales de médecine, IV, V.

\section{5}

-Sur les phénomènes chimiques de la digestion, deuxième mémoire. Analyse du suc gastrique. Avec Barreswill, Paris, Fain et Thunot, 1845, 7 p.

-Recherches expérimentales sur les phénomènes physiques de la digestion, troisième mémoire. Avec Barreswill, ADS, XXI.

\section{6}

-Des différences que présentent les phénomènes de la digestion et de la nutrition chez les animaux herbivores et carnivores, ADS, XXII.

-Sur la xyloïdine considérée comme substance alimentaire, avec Barreswill, ADS, XXIII.

\section{7}

-Expériences sur les nerfs pneumo-gastriques et spinaux ou accessoires de Willis, ADS, XXIV.

-Recherches sur les causes qui peuvent faire varier l'intensité de la sensibilité récurrente, ADS, XXV.

\section{8}

-De la présence du sucre dans le foie, avec Barreswill, ADS, XXVII.

\section{9}

-Recherches sur les usages du suc pancréatique dans la digestion, ADS, XXVIII.

\footnotetext{
${ }^{30}$ ADS: Comptes rendus de l'Académie des Sciences (Anais da Academia de Ciências)

${ }^{31} \mathrm{Cf}$. nota 9 desta dissertação.
} 


\section{0}

-C. Bernard obtém o Prêmio de Fisiologia Experimental (concurso de 1848) por sua tese Découverte de la fonction du pancréas dans l'acte de la digestion, ADS, XXX.

-Recherches sur le curare, avec Pelouze, ADS, XXX.

-Note sur une nouvelle espèce $d$ anastomoses vasculaires, ADS, XXXI.

-Sur une nouvelle fonction du foie chez l'homme et chez les animaux, Prêmio de Fisiologia Experimental de 1851, ADS, XXXI.

-Notice sur les travaux d'anatomie et de physiologie de M. Claude Bernard, Paris, Martinet, 1850, $37 \mathrm{p}$.

-Du rôle de l'appareil chylifère dans l'absorption des substances alimentaires, ADS, XXXI.

-De l'absorption élective de la veine porte et des vaisseaux chylifères, $\mathrm{SB}^{32}$.

-Note sur la présence du sucre dans l'urine du foetus et dans les liquides amniotiques et allantoïdiens, SB.

-Action du curare et de la nicotine sur le système nerveux et sur le système musculaire, SB.

-Rapport sur un mémoire de M. Hifflsheim : Quelques observations relatives à la circulation du sang, avec Brown-Séquard, SB.

-Faux hermaphrodisme (androgyne masculin, Gurlt) observé sur un chevreau, avec Rayer, SB.

-Sur les vaisseaux des épiploons lombaires de la Marmotte, avec Valenciennes, SB.

1851

-Sur les causes de l'apparition du sucre dans l'urine, avec Charcot, SB.

-Influence du grand sympathique sur la sensibilité et sur la calorification, SB.

1852

-Recherches d'anatomie et de physiologie comparées sur les glandes salivaires chez l'homme et les animaux vertébrés, ADS, XXXIV.

-De l'influence du système nerveux grand sympathique sur la chaleur animale, ADS, XXXIV.

-Notice sur les travaux de M. Claude Bernard, candidat à une place vacante à l'Académie des sciences dans la section de zoologie, Paris, Martinet, 1852, 39 p.

-Variations dans les phénomènes de la digestion chez les animaux, SB.

-Sur les phénomènes réflexes, SB.

-Expériences sur les fonctions de la portion encéphalique du grand sympathique, SB.

\footnotetext{
${ }^{32}$ SB: Comptes rendus de la Société de Biologie (Anais da Sociedade de Biologia)
} 
-Sur les effets de la section encéphalique du grand sympathique, SB.

-Sur les salives, SB.

\section{3}

-Note sur la multiplication des phénomènes qui résultent de la destruction de la partie cervicale du nerf grand sympathique, ADS, XXXVI.

-Expériences instituées pour déterminer dans quelles conditions certaines substances, qui sont habituellement gardées par le sang, passent dans l'urine, SB.

-Influence du sucre mélangé au sang par l'absorption de l'oxygène, SB.

-Recherches expérimentales sur le grand sympathique et principalement sur l'influence que la section de ce nerf exerce sur la chaleur animale, SB.

-Sur la destruction des glandes au moyen d'injections de matières grasses, SB.

-Sur les phénomènes d'absorption qui s'effectuent à la surface des conduits des glandes salivaires, SB.

-Recherches sur une nouvelle fonction du foie considéré comme organe producteur de matière sucrée chez l'homme et les animaux, thèse présentée à la Faculté des Sciences de Paris pour obtenir le grade de docteur ès sciences naturelles, soutenue le 17 mars 1853, Zoologie, Paris, Martinet, 1853, 97 p.

-Nouvelle fonction du foie considéré comme organe producteur de matière sucrée chez l'homme et les animaux, Paris, Baillière, 1853, 92 p.

\section{4}

-Influence que la portion cervicale du nerf grand sympathique exerce sur la température des parties auxquelles ses filets se distribuent en accompagnant les vaisseaux artériels, ADS, XXXVIII. O Prêmio de Fisiologia Experimental de 1853 foi atribuído a ele por esse estudo.

-Observation d'un cas de phtisie aiguë avec altération correspondante dans les reins, SB.

-Expériences relatives à la manière dont on fait l'endosmose à travers la peau des anguilles et des grenouilles, SB.

-Précis iconographique de médecine opératoire et d'anatomie chirurgicale, avec Ch. Huette, Paris, Méquignon-Marvis, 1854, 2 vol.

-Recherches expérimentales sur te grand sympathique, et spécialement sur l'influence que la section de ce nerf exerce sur la chaleur animale, lues à la Société de Biologie, dans les séances des 7 et 21 décembre 1853..., Paris, Thunot, 1854, 35 p. 


\section{5}

-Remarques sur la sécrétion du sucre dans le foie, faites à l'occasion des communications de M. Lehmann, ADS, XL.

-Note sur la présence du sucre dans le sang de la veine porte et dans le sang de la veine hépatique, ADS, $X L$.

-M. Cl. Bernard présente, au nom de l'auteur, M. Lehmann, une note sur une substance animale glycogène, $\mathrm{ADS}, \mathrm{XL}$.

-Sur le mécanisme de la formation du sucre dans le foie, ADS, XLI.

-M. Cl. Bernard présente, au nom de l'auteur, M. Lehmann, une note sur la recherche du sucre dans le sang de la veine porte, $\mathrm{ADS}, \mathrm{XLI}$

-M. Cl. Bernard présente au nom de M. Stilling deux mémoires sur la structure de la fibre nerveuse primitive, ADS, XLI.

-M. Cl. Bernard, à l'occasion du premier de ces deux mémoires, fait quelques remarques relatives à la structure de la moelle allongée et à la détermination du nœud vital, ADS, XLI.

-Réponse à une question faite par le prince Ch. Bonaparte relativement au sens de cette expression nœud vital, ADS, XLI.

-Sur l'action du charbon animal par rapport aux matières organiques et particulièrement aux matières albumineuses, SB.

-Sur les phénomènes glycogéniques du foie, SB.

\section{6}

-Recherches expérimentales sur la température animale, ADS, XLIII.

-Analyses physiologiques des propriétés des systèmes musculaires et nerveux au moyen du curare, ADS, XLIII.

-Innocuité de l'hydrogène sulfuré introduit dans les voies digestives, SB.

-Influence de l'alcool et de l'éther sur les sécrétions du tube digestif, du pancréas et du foie, SB.

-Fr. Magendie. Leçon d'ouverture du cours de médecine du Collège de France (29 février 1856), Paris, Baillière, 1856, $36 \mathrm{p}$.

-Leçons de physiologie expérimentale appliquée à la médecine, faites au Collège de France, publié par Henri Lefèvre, Paris, Baillière, 1855-1856, 2 vol.

-Mémoire sur le pancréas et sur le rôle du suc pancréatique dans les phénomènes digestifs, particulièrement dans la digestion des matières grasses neutres, Paris, Baillière, 1856. 


\section{7}

-Sur le mécanisme physiologique de la formation du sucre dans le foie, ADS, XLIV.

-À l'occasion d'une communication de Sanson sur la formation du sucre dans l'économie animale, M. Cl. Bernard fait connaître de nouveaux faits relatifs à la formation de la matière glycogène dans le foie, ADS, XLIV.

-Nouvelles expériences sur le nerf facial, $\mathrm{SA}^{33}$.

-De l'influence qu'exercent les différents nerfs sur la sécrétion de la salive, SB.

-Nouvelles recherches expérimentales sur les phénomènes glycogéniques du foie, SB.

-Note sur les quantités variables d'électricité nécessaire pour exciter les propriétés des différents tissus, SB.

-Leçons sur les effets des substances toxiques et médicamenteuses, publié par A. Tripier, Paris, Baillière, 1857.

\section{8}

-Sur les variations de couleur dans le sang veineux des organes glandulaires, suivant leur état de fonction ou de repos, ADS, XLVI.

-De l'influence de deux ordres de nerfs qui déterminent les variations de couleur du sang veineux dans les organes glandulaires, ADS, XLVII.

-Détermination, au moyen de l'oxyde de carbone, des quantités d'oxygène que contient le sang veineux des organes glandulaires à l'état de fonction et à l'état de repos, ADS, XLVII.

-Sur les variations de couleur du sang, SB.

-Sur une expérience relative à l'influence que les nerfs exercent sur les glandes et particulièrement aux phénomènes de circulation pendant la sécrétion glandulaire, SB.

-Leçon d'ouverture du cours de M. Claude Bernard au Collège de France. De la méthode expérimentale, de l'expérimentation et de ses perfectionnements, de la critique expérimentale, Paris, Malteste, 1858, $24 \mathrm{p}$.

-Leçons sur la physiologie et la pathologie du système nerveux, publié par A. Tripier, Paris, Baillière, 1858, 2 vol.

\section{9}

-Remarques concernant la question des générations spontanées, présentées à l'occasion d'une communication de M. Milne-Edwards, ADS, XLVIII.

\footnotetext{
${ }^{33}$ SA: Não há indicação de legenda para esta sigla na relação de obras desta página do CNRS que foi utilizada como fonte. Como ela aparece apenas uma vez, pode ter havido um erro de digitação da sigla SB.
} 
-Sur une nouvelle fonction du placenta, ADS, XLVIII.

-De la matière glycogène considérée comme condition de développement de certains tissus chez le foetus avant l'apparition de la fonction glycogénique du foie, ADS, XLVIII.

-Remarque à l'occasion d'une communication de M. Schiff, intitulée: De la nature de la granulation qui remplit les cellules hépatiques : amidon animal, ADS, XLVIII.

-De la présence du sucre dans le sang de la veine porte et dans celui des veines sus-hépatiques: expériences de M. Schmidt analysées par M. Bernard qui, à cette occasion, présente deux ouvrages, dans lesquels il a exposé les principaux résultats de ses recherches sur ce sujet, ADS, XLIX.

-Sur l'emploi du curare dans le traitement du tétanos : réponse à des remarques de M. Velpeau sur le fait rapporté par M. Vella, ADS, XLIX.

-Remarques à l'occasion d'une communication de M.H. Gintrac sur un cas de tétanos traumatique traité sans succès par le curare, ADS, XLIX.

-De la matière glycogène chez les animaux dépourvus de foie, SB.

-Sur l'action des nerfs, sur la circulation et la sécrétion des glandes, SB.

-Sur la cause de la mort chez les animaux soumis à une haute température, SB.

-Recherches sur l'origine de la glycogénie dans la vie embryonnaire; nouvelle fonction du placenta, SB.

-Leçons sur les propriétés physiologiques et les altérations pathologiques des liquides de I'organisme, publié par A. Tripier, Paris, Baillière, 1859, 2 vol.

\section{0}

-Sur le rôle des nerfs des glandes, SB.

\section{2}

-Recherches expérimentales sur les nerfs vasculaires et calorifiques du grand sympathique, ADS, LV.

-Des phénomènes oculo-pupillaires produits par la section du nerf sympathique cervical ; leur indépendance des phénomènes vasculaires calorifiques de la tête, ADS, LV.

\section{3-1864}

-Physiologie générale, RCS, 1re année, 15 cours.

\section{4}

-Recherches expérimentales sur l'opium et ses alcaloïdes, ADS, LIX.

-Recherches sur l'opium et ses alcaloïdes, SB. 


\section{4-1865}

-Cours de physiologie générale de 1864 sur les mouvements réflexes et leur rôle dans l'organisme, $\mathrm{RCS}^{34}, 2 \mathrm{e}$ année, 3 cours.

-Cours de physiologie générale de 1865 sur les liquides de l'organisme et en particulier sur le sang, RCS, 2e année, 4 cours.

-Cours de médecine expérimentale sur le cœur considéré comme moyen d'investigations biologiques, RCS, 2e année, 21 cours.

-Conférence sur le cœur et ses rapports avec le cerveau, RCS.

\section{5}

-Introduction à l'étude de la médecine expérimentale, Paris, Baillière, 1865, 400 p.

-Notes sur les effets physiologiques de la curarine, ADS, LX.

-Note accompagnant la présentation des Leçons faites au Collège de France et de I'Introduction à la médecine expérimentale, ADS, LXI.

-Du progrès dans les sciences physiologiques, Revue des Deux Mondes, t. 58, 1865.

-Repris dans La science expérimentale, 1878.

\section{6}

-Leçons sur les propriétés des tissus vivants, cours de physiologie générale à la Faculté des Sciences. Rédigé et publié par Émile Alglave, Paris.

\section{7}

-Rapport sur les progrès et la marche de la physiologie générale en France, Paris, Imprimerie impériale, 1867, $237 \mathrm{p}$.

\section{7-1868}

-Phénomènes d'organisation et de connexion organique, 1., RCS, 5e année.

-L'innervation du cœur, RCS, 5e année.

-Génération et dissémination des helminthes, RCS, 5e année.

-La déglutition, RCS, 5e année.

-L'observation et l'expérimentation en physiologie, RCS, 5e année.

-Rapport sur les progrès et la marche de la physiologie générale en France.

\section{8-1869}

-La médecine d'observation et la médecine expérimentale, RCS, $6^{\mathrm{e}}$ année.

\footnotetext{
${ }^{34}$ RCS: Revue des cours scientifiques (Resumo de cursos científicos ou de aulas de Ciências)
} 
-L'expérimentation dans les sciences de la vie, RCS, 6e année.

-L'empirisme et le rationalisme dans l'expérimentation physiologique, RCS, 6e année.

-La critique expérimentale, RCS, 6e année.

-Discours de M. Claude Bernard, prononcé à sa réception à l'Académie française, le 27 mai 1869, Paris, Didier, 1869, $53 \mathrm{p}$.

\section{0}

-L'évolution de la médecine scientifique et son état actuel, RCS, 7e année, 11 cours.

\section{1-1872}

-L'influence de la chaleur sur les animaux, $\mathrm{RS}^{35}, 1^{\text {re }}$ année, 2 mémoires.

-La méthode et les principes de la physiologie, RS, 1re année.

\section{2}

-La chaleur animale, RS, 1re année, 40 leçons.

-Calorification dans I'asphyxie, SB.

-Exophtalmie par irritation nerveuse, SB.

-Nerfs sécréteurs et nerfs vaso-moteurs des glandes salivaires, SB.

-Évolution du glycogène dans l'œuf des oiseaux, ADS, LXXV.

-Des phénomènes de la vie communs aux animaux et aux végétaux, 1. RS, 2e année.

-La sensibilité et le mouvement, RS, 2e année.

-La respiration, RS, 2e année.

-L'eau et l'air atmosphérique, RS, 2e année.

-Formation des principes immédiats, RS, 2e année.

-La glycogenèse animale, RS, 2e année.

-Leçons de pathologie expérimentale, publié par Benjamin Bail, Paris, Baillière, 1872, 604 p.

-De la physiologie générale, Paris, Hachette, 1872, 339 p.

1873

-Passage de l'air des canaux glandulaires dans les capillaires, SB.

-Considérations relatives à la glycogenèse animale, SB.

-Remarques sur les nerfs des reins, SB.

-Action de l'excitation des nerfs sensitifs sur la circulation et sur la glande sous-maxillaire, SB. -Histoire de la chaire de médecine au Collège de France, RS, 2e année.

\footnotetext{
${ }^{35}$ RS: Revue scientifique (Resumo científico)
} 
-L'évolution de la médecine scientifique, RS, 2e année.

-Le diabète, étude chimique et traitement RS, 2e année.

-La nutrition et les urines, RS, 2e année.

-Recherches du sucre dans les urines, RS, 2e année.

-La glycémie physiologique, RS, 2e année.

-Dosage du sang dans les divers vaisseaux, RS, 2e année.

-Origine du sucre dans le sang, digestion du sucre de canne, RS, 2e année.

-Le foie est une source physiologique de glucose, RS, 2e année.

-Double fonction glycogénésique et glycogénique du foie, RS, 2e année.

-Conditions diverses de la glycémie et de la glycosurie, RS, 2e année.

-La glycogénie interprétée par les vitalistes, RS, 2e année.

\section{3-1874}

-Cours du Collège de France : médecine expérimentale, RS, 3e année.

-Le diabète, RS, 3e année, 5 leçons.

\section{4}

-Physiologie du nerf trijumeau, SB.

\section{5}

-Action de la strychnine et du curare chez les grenouilles, SB.

-Médecine expérimentale ; la médecine et la physiologie, RS, 4e année.

-L'anatomie et l'expérimentation physiologique, RS, 4e année.

-L'appareil circulatoire dans l'ensemble de l'organisme, RS, 4e année.

-Le système capillaire, RS, 4e année.

-L'absorption, RS, 4e année.

-Les voies de l'absorption, RS, 4e année.

-Rapport des vaisseaux lymphatiques avec les capillaires sanguins, RS, $4^{\mathrm{e}}$ année.

-Absorption interne, absorption externe, RS, 4e année.

-Les trois phases de l'absorption, RS, $4^{\mathrm{e}}$ année.

-Origine des veines, cœurs périphériques veineux et lymphatiques, $\mathrm{RS}, 4^{\mathrm{e}}$ année.

-Exsudation de la lymphe, diapédèse des globules blancs, les divers sangs veineux, RS, 4 e année.

-Les vivisections, les poisons comme instruments d'analyses physiologiques, le curare, RS, $4 \mathrm{e}$ année.

-Suite du chapitre précédent, acide prussique, strychnine, RS, 4e année. 
-Respiration artificielle, RS, 4e année.

-Leçons sur les anesthésiques et sur l'asphyxie, publié par Mathias Duval, Paris, Baillière, 1875. (Trata-se do Curso de Medicina no Collège de France.)

\section{5-1876}

-Leçons sur la chaleur, sur les effets de la chaleur et sur la fièvre, RS.

\section{6}

-Critique expérimentale sur la formation de la matière sucrée chez les animaux, ADS, LXXXII, 3 mémoires.

-Critique expérimentale sur la glycémie (suite). Des conditions physico-chimiques et physiologiques à observer pour la recherche du sucre dans le sang ", ADS, LXXXII, 2 mémoires.

-Note sur un moyen rapide de dosage de la chaux au moyen de la magnésie, et sur l'application de la magnésie à la défécation des jus sucrés, avec Ehrmann. ADS, LXXXIII.

-Critique expérimentale sur la glycémie (suite); la glycémie est le résultat d'une fonction physiologique ; elle prend sa source dans l'organisme et non dans I'alimentation, ADS, LXXXIII, 2 mémoires.

-Éthérisation appliquée aux végétaux et aux animaux, SB, 2 mémoires.

-Anesthésie pouvant être produite chez tous les êtres vivants, SB.

-Leçons sur la chaleur animale, sur les effets de la chaleur et sur la fièvre, publié par Mathias Duval, Paris, Baillière, 1876, $471 \mathrm{p}$.

\section{7}

-Critique expérimentale sur la fonction glygogénésique du foie, ADS, LXXXIV.

-Leçons sur le diabète et la glycogenèse animale, ADS, LXXXIV.

-Leçons sur le diabète et la glycogenèse animale, publié par Mathias Duval, Paris, Baillière, 1877, 576 p. (Trata-se do Curso de Medicina no Collège de France.)

\section{8- Mort de Claude Bernard}

-La science expérimentale, Paris, Baillière, 1878, 440 p.

\section{8-1879}

-Leçons sur les phénomènes de la vie, communs aux animaux et aux végétaux, publié par A. Dastre, Paris, Baillière, 1878-1879, 2 vol. (Il s'agit du cours de physiologie générale au Muséum.)

\section{9}

-Leçons de physiologie opératoire, publié par Mathias Duval, Paris, Baillière, 1879, 614 p. 


\section{7}

-Pensées. Notes détachées, préface par le prof. d'Arsonval. Introduction et notes par le Dr Léon Delhoume, Paris, Baillière.

-Philosophie. Manuscrit inédit, édité et présenté par Jacques Chevalier. Préface de Justin Godart, Paris, Boivin.

\section{2}

-Le cahier rouge, introduction par le Dr Léon Delhoume, Paris, Gallimard.

\section{7}

-Principes de médecine expérimentale, avant-propos par Léon Binet. Introduction et notes par Léon Deihoume, Paris, PUF.

\section{1}

-Pages choisies, introduction et notes par Ernest Kahane, Paris, Éditions Sociales.

\section{5}

-Cahier de notes 1850-1860, présenté et commenté par Mirko Grmek, Paris, Gallimard.

Aqui se encontra, portanto, uma lista, que talvez não seja ainda exaustiva, da imensa obra que nos proporcionou este cientista do século XIX. Ter a chance de conhecer pelo menos uma parte desta obra é um verdadeiro privilégio e, torná-la acessível ao maior número possível de leitores não francófonos, é uma forma de contribuir para que toda a riqueza de seu legado possa alcançar o maior número possível de pessoas que possam compreender sua importância e levar adiante tão importantes contribuições para a ciência. 


\section{CAPÍTULO 2: O PROJETO DE TRADUÇÃO - BASES TEÓRICAS}

A tradução tem a ver com a descoberta; é uma viagem de exploração pelo reino fabuloso do conhecimento.

Jean-François Joly

\subsection{Opções de tradução: a dicotomia domesticação x estrangeirização}

Traduzir é ato necessário à difusão do conhecimento. Segundo Oustinoff (2011, p.7), “a tradução constitui, em seu próprio princípio, uma operação fundamental da linguagem". Essa afirmação não é nova, uma vez que já foi enunciada por diversos estudiosos, como Jakobson em seu texto clássico sobre tradução (cf. JAKOBSON, 1959, p. 64-65), no qual convoca outros pesquisadores, anteriores a ele, para tratar do assunto; ela é, porém, verdadeira. Desde os primórdios, a tradução se fez necessária não só na comunicação humana em trocas linguísticoculturais banais e cotidianas ou em confrontos entre povos de línguas diferentes, mas também na importação ou exportação de ideias, técnicas e produtos.

Mas o que é traduzir? Etimologicamente, essa palavra deriva do latim traducere, que significa conduzir além, transferir (cf. FERREIRA, Aurélio Buarque de Holanda, 1986, p. 1696). Com o passar do tempo, esse termo foi adquirindo a conotação de transferir sentido de uma língua para outra, revelar. Atualmente, considera-se o ato de traduzir uma operação de transferência linguística entre diferentes códigos, como nos lembra Berman (2012, p.320), baseado nas ideias propostas por Jakobson:

Para o linguista, assim como para o usuário comum da linguagem, o sentido de uma palavra não é nada mais do que sua tradução para um outro signo que pode substituí-lo [...]. Distinguimos três maneiras de interpretar um signo linguístico, conforme o traduzimos para outros signos da mesma língua, numa outra língua, ou num sistema de símbolos não linguísticos.

De fato, Jakobson (1959, 2007, p. 64-65), em sua obra Aspectos Linguísticos da Tradução, distingue três tipos de atividade tradutória: 
1) A tradução intralingual ou reformulação (rewording), que consiste na interpretação dos signos verbais por meio de outros signos da mesma língua.

2) A tradução interlingual ou tradução propriamente dita, que consiste na interpretação dos signos verbais por meio de alguma outra língua.

3) A tradução inter-semiótica ou transmutação, que consiste na interpretação dos signos verbais por meio de sistemas de signos não-verbais.

Schleiermacher $(1813,2007)$ também discorre sobre diferentes tipos de tradução, os quais, de certa forma, antecedem com outras palavras os mesmos tipos levantados anteriormente por Jakobson. Porém, este autor dá mais atenção aos diferentes processos de tradução, enfatizando o papel desempenhado por ela no que se refere à tradução interlingual, em que chama também a atenção para o aspecto diacrônico. Diz ele:

O fato, que um discurso numa língua seja traduzido numa outra, apresenta-se a nós sob as mais variadas formas por toda a parte. Por um lado, desse modo podem entrar em contato homens geograficamente muito afastados, e podem ser transpostas numa língua obras de uma outra extinta já há muitos séculos (SCHLEIERMACHER, 1813, 2007, p. 233).

Esse autor continua, ainda na página citada, a elencar diferentes tipos de tradução, dizendo que ela pode se fazer necessária dentro de uma mesma língua quando existem dialetos resultantes do desenvolvimento diferencial de uma mesma língua ao longo dos séculos. Ressalta que, além disso, pode haver variações de uma mesma língua numa mesma época, entre contemporâneos de diferentes classes sociais ou que possuam "sensibilidade e ânimo diferentes" (SCHLEIERMACHER, 1813, 2007, p. 234). Ele acrescenta ainda que existem até mesmo casos em que traduzimos aquilo que nós mesmos pensamos ou dizemos: “As nossas próprias palavras, às vezes, temos que traduzir após algum tempo, se quisermos assimilá-las apropriadamente outra vez" (SCHLEIERMACHER, 1813, 2007, p.234).

Nosso trabalho desenvolve um projeto de tradução interlingual, ou seja, entre duas línguas, que se encontram separadas por espaços geográficos diferentes: o francês da França e o português do Brasil. Além disso, trata-se de uma tradução que leva em conta as diferenças 
temporais, já que entre o texto fonte e o texto traduzido há um tempo decorrido de cerca de 150 anos, o que nos leva a considerar também as variações decorrentes do tempo que as separa.

Outro aspecto que também chama a atenção nos estudos tradutológicos desde seus primórdios diz respeito às dicotomias que ainda persistem nas discussões a respeito da prática tradutória como a da tradução da forma vs. tradução do sentido. Segundo Yang (2010, p. 77):

Muitas teorias da tradução, de Cícero (106-43 a.C.) ao século XX, foram centradas no debate recorrente e estéril de como a tradução poderia ser feita de forma literal (palavra por palavra) ou de forma livre (privilegiando o sentido). Isso foi discutido por São Jerônimo em sua tradução da Bíblia para o latim.

Além dessa dicotomia, que tem registros quase tão antigos quanto a própria prática tradutória, outra bastante recorrente é aquela inicialmente levantada pelo filósofo e teólogo alemão já citado, Friedrich Schleiermacher $(1913,2007)$ na célebre conferência Über die verschiedenen Methoden des Übersetzens (Sobre os Diferentes Métodos de Tradução), ministrada na Academia Real de Ciência de Berlim em 1813 e depois publicada em suas Obras Completas. Berman (2012, p.259, grifos do autor) referiu-se a esse ensaio dizendo que "trata-se sem dúvida do único estudo dessa época na Alemanha que constitui uma abordagem sistemática e metódica da tradução." Ele explica, como vemos a seguir, cada uma dessas abordagens, isto é, a sistemática e a metódica.

Berman (1984, 2012, p. 259, grifos do autor), justifica sua afirmação a respeito do ensaio realizado por Schleiermacher dizendo considerar seu estudo uma abordagem sistemática porque

Shleiermacher procura delimitar a extensão do ato de traduzir no campo total da compreensão, delimitação que se opera pela exclusão progressiva do que não é esse ato e por sua situação articulada nesse campo. Uma vez feita essa delimitação, torna-se então possível proceder a um exame (ele próprio sistemático) das traduções existentes e de criar uma metodologia da tradução aplicada aos diferentes gêneros de Rede. São esses os passos que seguem sua Hermenêutica.

Em seguida, para justificar o fato de considerar que o trabalho de Schleiermacher apresenta pela primeira vez uma abordagem metódica dos estudos da tradução, Berman (1984, 
2012, p. 259) afirma que isto ocorre "pois não se trata apenas, para Schleiermacher, de analisar, mas de deduzir, a partir de definições, os métodos possíveis de tradução".

A dicotomia levantada por Schleiermacher naquela ocasião diz respeito às duas possíveis opções feitas por um tradutor e por ele assim definidas: levar o leitor da tradução ao contexto do autor ou trazer o autor para o contexto do leitor. Esta contraposição entre dois procedimentos tradutórios foi retomada de forma bastante incisiva por dois autores: o próprio francês Antoine Berman, em 1984, em seu livro L'épreuve de l'étranger (A Prova do Estrangeiro) e, mais recentemente, pelo norte-americano Lawrence Venuti em seu livro The translator's invisibility, publicado em 1995. Este último cria, a partir dos trabalhos de Schleiermacher, os termos hoje bastante difundidos que estabelecem duas possibilidades de tradução: a domesticadora, que traz o autor para o mundo do leitor, e a estrangeirizadora, que leva o leitor para o mundo do autor.

A existência dessa dicotomia, que detalharemos mais adiante, acaba por colocar o tradutor diante de um dilema, conduzindo-o a uma situação em que ele é levado a escolher um caminho no decorrer do processo tradutório. Essa escolha se coloca diante de qualquer tradutor/tradução e depende, por exemplo, dos objetivos que ele deseja alcançar ou de qual será o público para o qual será dirigido o seu texto.

Não podemos esquecer também que a tarefa de tradução interlingual, ao tratar do contexto de línguas diferentes, envolve diferentes culturas, colocando-as frente a frente, permeando o texto traduzido de maior ou menor quantidade de referências a cada uma delas. Por esta razão, essas abordagens realizadas pelos dois autores mais recentes acima citados (Berman e Venuti) desenvolveram-se sob o viés ético, que leva em conta tornar o texto mais estranho ou mais familiar para o leitor, dependendo do que o tradutor escolhe na sua prática.

A respeito dessa escolha, Britto (2010, p.136) diz que "o trabalho do tradutor é uma forma de mediação cultural. Traduzir é um processo de mediação bem complexo que necessariamente envolve um grau elevado de manipulação. " Assim, a opção de tradução se apresenta como um aspecto a ser pensado com muito cuidado por aquele que realiza a tarefa de traduzir, exigindo que ele tenha claras para si as justificativas de sua escolha. Como enfatizam Batalha e Pontes 
(2007, p.97) “não existe 'tradução boa' e 'tradução ruim'; existem traduções pertinentes e traduções impertinentes para determinados fins".

Ainda com relação à importância de uma opção consciente relacionada à tarefa tradutória, Schleiermacher $(1813,2007$, p.240) diz que “é preciso conhecer muito bem, além da língua, cada obra, seu autor, a vida histórica para poder 'desejar abrir ao seu povo e contemporâneos a mesma compreensão das obras primas da arte e da ciência. ' E o mesmo autor ainda complementa: "as línguas não se inventam, e trabalhar nelas ou sobre elas de modo puramente arbitrário é sempre um disparate" (SCHLEIERMACHER, 1813, 2007, p. 246).

Venuti (1998, p.19-20) comenta com relação à opção do tradutor, tendo como base os trabalhos do filósofo alemão:

A questão mais urgente encarada pelo leitor [...] é, o que fazer? Por que e como devo traduzir? Embora eu tenha estruturado a tradução como o espaço de muitas determinações e efeitos - linguístico, cultural, econômico, ideológico quero também apontar que o tradutor literário autônomo sempre exerce, em qualquer tradução, uma escolha com relação ao grau e direção da violência do seu trabalho. Esta escolha tem sido formulada de várias formas, no passado e no presente, mas talvez nenhuma tenha sido tão decisiva quanto aquela oferecida pelo teólogo e filósofo alemão Friedrich Schleiermacher.

Ao falar da violência do trabalho do tradutor, Venuti refere-se ao fato de que, ao traduzir, o indivíduo que privilegia a língua alvo pode acabar modificando de tal modo o texto original para adequá-lo ao leitor que acaba cometendo uma violência contra essa língua.

A respeito da responsabilidade do tradutor ao fazer sua opção de tradução, Trevisani (2007, p.38) comenta que o tradutor não é uma ferramenta eletrônica e sim um ser humano, com suas próprias concepções sociais e ideológicas. Desta forma, suas escolhas não podem deixar de interferir na obra traduzida, mesmo que ele o faça de forma inconsciente.

Essa mesma autora ainda enfatiza que não há como dissociar o processo de tradução dos aspectos sociais e culturais relacionados à língua alvo, lembrando o quanto isso torna difícil a tarefa do tradutor e aumenta sua responsabilidade com relação às escolhas que ele fará. Ela afirma que 
teoria e prática do processo de tradução de uma língua para outra estão fundamentalmente relacionadas a uma concepção de língua como uma dimensão inseparável dos falantes de uma sociedade, sua cultura, seus valores, sua política e ideologias. Ao considerar tal grau de indissociabilidade entre uma língua e as práticas sociais vivenciadas pelos indivíduos por meio dessa língua, tem-se a impressão de que traduzir práticas linguísticas de determinada cultura em termos de uma outra língua, objetivando atingir outra comunidade de falantes, seja tarefa inexequível (TREVISANI, 2007, p.36-7).

A nosso ver, parece que, ao propor as formas de tradução em sua palestra em 1813, Schleiermacher estava na verdade tentando encontrar uma saída para esse impasse, refletindo a respeito desse problema e sugerindo ao tradutor as possibilidades de resolução para tal dilema, o que foi colocado pelo filósofo alemão desta forma:

Mas agora, por que caminhos deve enveredar o verdadeiro tradutor que queira efetivamente aproximar estas duas pessoas tão separadas, seu escritor e seu leitor, e propiciar a este último, sem obrigá-lo a sair do círculo de sua língua materna, uma compreensão correta e completa e o gozo do primeiro? Ou bem o tradutor deixa o escritor o mais tranquilo possível e faz com que o leitor vá a seu encontro, ou bem deixa o mais tranquilo possível o leitor e faz com que o escritor vá ao seu encontro. Ambos são tão completamente diferentes que um deles tem que ser seguido com o maior rigor, pois qualquer mistura produz necessariamente um resultado muito insatisfatório, e é de temer-se que o encontro do escritor e do leitor falhe inteiramente (SCHLEIERMACHER, 1813, 2007, p. 242).

Nesse sentido, Berman (2012, p. 259-60), ao retomar os trabalhos de Schleiermacher, comenta a dicotomia ali proposta dizendo que no primeiro caso, a opção do tradutor obriga o leitor a fazer um esforço de descentramento, pois ele é obrigado a sair de si mesmo para perceber o autor estrangeiro e, no segundo caso, o que o tradutor faz é obrigar o autor a se despojar de sua estranheza, para que ele possa se tornar familiar ao leitor.

Ao propor esses dois possíveis caminhos, Schleiermacher $(1813,2007$, p. 243) é enfático ao assegurar que o tradutor não pode se privar de optar por um deles. Nas suas palavras: 
Assim, pois, tudo o que se disse sobre traduções segundo a letra ou segundo o espírito, traduções fiéis ou traduções livres, e tantas outras expressões que pudessem alegar o direito de vigência ainda que se trate de métodos diversos, têm que poder reduzir-se aos dois mencionados.

O que vemos a seguir na palestra proferida por Schleiermacher em 1813 é que ele faz uma clara opção por aquele caminho que leva o leitor até o autor do texto. Ele defende esse método, o que fica claro no trecho abaixo:

O leitor deve ter sempre presente que o autor viveu em outro mundo e escreveu em outra língua. Ele apenas tem de atender à arte, sem dúvida difícil, de suprir o conhecimento deste mundo estranho de maneira mais rápida e conveniente, e deixar que em toda parte transpareça a grande leveza e naturalidade do original (SCHLEIERMACHER, 1813, 2007, p. 261).

Ele conclui acrescentando que uma língua "apenas pode florescer e desenvolver plenamente sua própria força por meio dos mais variados contatos com o estrangeiro" (SCHLEIERMACHER, 1813, 2007, p. 264).

Para Britto (2010, p.139), a opção de Schleiermacher por manter a estranheza do texto original é bastante clara, o que fica evidente quando ele afirma que esta atitude representa o respeito pela língua e pela cultura estrangeiras. Para ele, "um respeito tão profundo que leva o tradutor a por vezes ultrapassar os limites de seu próprio idioma, distorcendo-o de modo calculado a fim de conservar algo da qualidade alheia, estranha, do estrangeiro" (Britto, 2010, p.139). Ele acredita ainda que o fato de o Outro pertencer a uma cultura central ou periférica não deve importar, sendo sempre necessário respeitá-lo em sua especificidade e estranheza. Uma ressalva importante levantada por este autor é a de que este tipo de opção por parte do tradutor exige dele uma boa dose de autoconfiança. Segundo suas palavras:

Há culturas que se sentem seguras de si o bastante para permitirem que a elas se incorporem elementos estrangeiros sem medo de que se descaracterizem. Já outras encaram seu próprio patrimônio cultural, principalmente o idioma, como um tesouro valioso, porém extremamente frágil, que é preciso proteger constantemente das forças externas que poderiam fazê-lo desfigurar-se, ou mesmo desintegrar-se. 
É importante ressaltar que Schleiermacher proferiu sua palestra sobre os diferentes tipos de tradução no contexto de uma época em que a Alemanha buscava uma identidade cultural e linguística, durante o período do Romantismo, e que, mergulhado nessa realidade, ele acreditava que as traduções de obras estrangeiras poderiam levar ao enriquecimento da língua alemã. Esta concepção fica bastante evidente no trecho a seguir:

E com isto vem coincidir, sem dúvida, o fato de que nosso povo [alemão], por sua atenção ao estrangeiro e por sua natureza mediadora, parece estar destinado a reunir em sua língua, junto com os próprios, todos os tesouros da ciência e arte alheios, como num grande conjunto histórico que se guarda no centro e coração da Europa, para que, com a ajuda de nossa língua, qualquer um possa gozar, com a pureza e perfeição possível a um estranho, a beleza produzida pelos tempos mais diversos. Esta parece ser, com efeito, a verdadeira finalidade histórica da tradução, em grande escala, tal como se pratica entre nós (SCHLEIERMACHER, 1813, 2007, p.263-264).

Caetano (2013, p.177) confirma o ideal do enriquecimento da língua proposto pelo autor alemão em 1813 ao comentar que, "em sua assertividade, a proposta de Schleiermacher traz em si o desejo do ganho cultural por meio da tradução. Assim, seu texto se configura como um elogio a essa atividade linguística. "

Yang (2010) também comenta a respeito da opção do filósofo alemão pela tradução que leva o leitor ao autor, ao observar que, em sua palestra intitulada Sobre os diferentes tipos de tradução, ele ressaltou a importância de que traduções de línguas diferentes para o alemão deveriam soar de forma diferente, levando o leitor a perceber, por exemplo, que havia algo do espanhol por detrás da tradução do espanhol, grego, por detrás da tradução grega. Ela lembra que para esse autor, a partir de seus comentários, fica claro que se algo "soasse familiar ao leitor alemão, a identidade do texto fonte seria perdida, modificada para se parecer com a da cultura alvo" (Yang, 2010, p.78).

Berman (1984, 2012, p.17-18), ao retomar os trabalhos de Schleiermacher, confirma essa opção, afirmando que "a essência da tradução é ser aberta, diálogo, mestiçagem, descentralização. Ela é relação, ou não é nada". E complementa: "chamo de má tradução a 
tradução que, geralmente sob o pretexto de transmissibilidade, opera uma negação sistemática da estranheza da obra estrangeira. Berman considera que o ganho de uma tradução que não nega a estranheza do texto original é incontestável. Ele afirma que "a tradução faz girar a obra, revela dela uma outra vertente. [...] Re-produzindo o sistema-da-obra em sua língua, a tradução provoca nesta uma mudança, e aí existe, indubitavelmente, um ganho, uma "potencialização" (Berman,1984, 2012, p.17-18). Ele acredita que muitas vezes, nesse processo, uma obra traduzida é "regenerada", pois ela "desperta possibilidades ainda latentes e que só ela, de maneira diferente da literatura, tem o poder de despertar" (BERMAN, 1984, 2012, p.21).

Os trabalhos de Berman foram escritos sob o viés da ética e sua escolha envereda pelo mesmo caminho privilegiado pelo filósofo alemão, isto é, levar o leitor até o autor e, segundo Trevisani (2007, p.37), “dessa concepção decorre o ideal da tradução ética, aquela que não apaga a estranheza do estrangeiro, mas que conduz o leitor ao autor e proporciona àquele a oportunidade de conhecer e apreciar o que é diferente de si, ainda que haja riscos [...]".

Outros autores, como Vicentini, Ferreira e Peixoto (2008, p.189) também levantaram a questão da ética no ato de traduzir ligada à escolha que deve fazer o tradutor. Segundo esses autores, "é a partir da relação dialógica entre duas línguas, duas culturas, enfim entre diferenças, que podemos situar e discutir a questão da ética no traduzir. Pois traduzir é traduzir o diferente. $\mathrm{O}$ ato ético consiste em reconhecer e receber o outro enquanto outro. "

Berman (1984, 2010, p. 270, grifos do autor) deixa bem clara sua posição diante dessa questão, optando claramente pelo mesmo caminho apontado por Schleiermacher, isto é, o de levar o leitor até o texto original, deixando-o conhecer e tomando contato com tudo o que ele pode trazer de estranho:

\footnotetext{
"Apresentar o estrangeiro em sua língua materna", aceitar que esta seja ampliada, fecundada, transformada por esse "estrangeiro", aceitar a "natureza mediadora" deste, essa é uma escolha que antecede qualquer consideração estreitamente metodológica. Ora, uma escolha é sempre uma escolha de um método [...], de um caminho, é sempre o traçado de um campo a ser percorrido, esquadrinhado, cultivado.
} 
Mais adiante, Berman (1984, 2010, p. 280) reafirma essa posição, ao afirmar que "a tradução não é um paliativo, mas o modo de existência pelo qual uma obra estrangeira chega até nós como estrangeira. A boa tradução mantém essa estranheza tornando a obra acessível a nós".

Como já dissemos, algum tempo depois de Berman ter retomado os trabalhos de Schleiermacher e de ter apoiado sua opção pela manutenção do texto estrangeiro como uma forma de respeito ao Outro, Venuti (1995, p. 19-20) retomou as ideias de ambos, cunhando para este tipo de caminho o termo estrangeirização. Em contraposição, o caminho que visa adaptar o texto alvo à cultura de chegada foi por ele chamado de domesticação.

Batalha e Pontes (2007, p. 86-87) consideram que o estudo do pesquisador norteamericano sobre o processo tradutório é polêmico, pois ele considera que, por um lado, no processo de domesticação que sofrem os textos traduzidos com o intuito de deixar o leitor à vontade, uma obra estrangeira é adaptada para o universo da língua-alvo, apagando diferenças e retirando suas características exóticas, o que pode levar a distorções semânticas e perda de traços culturais que estavam presentes na obra original. Por outro lado, no conceito que se opõe a este, o da estrangeirização, Venuti defende que sejam mantidos os elementos estilísticos e lexicais do texto original, levando o leitor a experimentar a estranheza do universo do autor. Entre esses dois caminhos propostos por Venuti, concluem, restará ao tradutor fazer a sua escolha.

Yang (2010, p.78, grifo nosso), apresenta de forma bastante clara a dicotomia finalmente proposta pelo estudioso norte-americano, resumindo-a desta forma:

Simplificadamente falando, a domesticação designa o tipo de tradução na qual é adotado um estilo transparente e fluente para minimizar a estranheza do texto estrangeiro para os leitores da língua alvo, enquanto estrangeirização significa que o texto alvo é produzido incluindo deliberadamente quebras de convenções da língua alvo, mantendo algo da estranheza do original.

Antes mesmo de cunhar esses termos, Venuti (1991, p.126, tradução nossa) mostra que suas ideias são pautadas numa visão política do procedimento do tradutor e que ele estava bastante preocupado com essas questões. Essas discussões o levariam a propor pouco mais tarde 
os termos hoje consagrados. Ele afirma em seu artigo que editores, revisores ou leitores consideram que um texto é bem traduzido quando lido com fluência, quando dá até mesmo a impressão de que não foi traduzido, de que se trata de um texto original. Nele, deve estar refletida a personalidade do autor estrangeiro, a sua intenção, o significado essencial do que ele pretendia dizer. Ele complementa com este raciocínio:

A estratégia de tradução fluente produz o efeito de transparência, pondo em primeiro plano o significado conceitual e minimizando qualquer jogo perturbador de significantes, buscando sintaxe linear, sentido unívoco, uso atual, a coerência linguística. Ao mesmo tempo, no entanto, a fluência resulta num apagamento das várias determinações e efeitos de conversão (VENUTI, 1991, p.126, tradução nossa).

Esse apagamento resultaria, segundo ele, na "invisibilidade do tradutor", nome que levaria posteriormente o livro no qual essas ideias foram sedimentadas, dentre as quais, a da presença não notada do tradutor, na fluência do texto domesticado, o que é para Venuti um aspecto considerado bastante negativo. Segundo ele, quando estratégias que favoreçam a transparência são implementadas, elas realizam inevitavelmente um "trabalho de aculturação em que um outro cultural é domesticado, tornado inteligível, mas também familiar, até igual, pois é codificado com discursos culturais ideológicos que circulam na língua-alvo" (Venuti, 1991, p.127, tradução nossa).

Venuti considera que a ética da tradução defendida por Berman foi um passo importante para a visibilidade do tradutor. Para Martins (2010), Venuti mostra-se desse modo favorável à estrangeirização porque este procedimento implica na rejeição da fluência que predomina na tradução contemporânea, representando uma estratégia de resistência que, segundo esta autora, "impede o efeito ilusionista de transparência no texto traduzido e torna visível o trabalho do tradutor" (MARTINS, 2010, p. 66). Ainda segundo ela, desta forma o tradutor "tem função política e cultural e ajuda a preservar a diferença linguística e cultural do texto estrangeiro ao produzir traduções estranhas, pouco familiares [...] (MARTINS, 2010, p. 66).

Martins (2010, p.66) também explica as razões que levam Venuti a criticar o processo de domesticação aplicado pelos tradutores quando estes optam por trazer o texto fonte até o leitor, 
reescrevendo-o e alterando-o. Segundo ela, as críticas de Venuti ao que predomina no sistema cultural anglo-americano se devem ao fato dele acreditar que elas têm como objetivo o apagamento do tradutor no texto traduzido, além de anular as diferenças linguística e cultural que se encontram no texto original. Ela ressalta que ele considera que ao reescrever o discurso transparente, o resultado é que ele traz os valores, crenças e representações sociais da cultura alvo e que a busca de fluência "realiza um trabalho de aculturação que domestica o texto estrangeiro, tornando-o inteligível (no sentido de acessível, familiar) para o leitor do texto traduzido" (MARTINS, 2010, p.66)

Nas próprias palavras de Venuti (2002, p.129), sua posição favorável à estrangeirização e contrária à domesticação é explicitada no trecho a seguir, no qual ele aponta uma importante ressalva, a fim de se estabelecer um limite para que o texto que leva o leitor ao autor não acabe se tornando tão estranho ao leitor, a ponto de se tornar ininteligível.

Um projeto tradutório pode se distanciar das normas domésticas a fim de evidenciar a estrangeiridade do texto estrangeiro e criar um público-leitor mais aberto a diferenças linguísticas e culturais, mas sem ter que recorrer a experiências estilísticas que são tão alienadoras a ponto de causarem o próprio fracasso (VENUTI, 2002, p.166).

Berman (1984, 2012, p.276) também leva em conta o fato de que é preciso ter em mente que existe um limite para aquilo que é mantido como exótico ou estrangeiro em um texto, limite este que, uma vez ultrapassado, poderia alterar de forma inadequada o texto alvo. Ele observa que existe um limiar (que ele não sabe qual é e nem como ou quem o estabelece) entre uma estranheza insignificante, sem relação com a verdadeira estranheza do texto, e uma estranheza que rebaixa o texto ao que é exótico, incompreensível. Ele afirma:

Por mais que se tenha sentido o estrangeiro, mas não a estranheza, a tradução terá atingido seus objetivos supremos; mas no lugar em que aparece a estranheza como tal, obscurecendo talvez o estrangeiro, o tradutor denuncia que não está à altura de seu original. O sentimento do leitor não prevenido não deixará de notar aqui a linha divisória (BERMAN, 1984, 2012, p. 276). 
Muito embora a aludida linha divisória seja, segundo ele, algo difícil de identificar, Berman considera que "pode estar aí o terrível da diferença, mas também sua maravilha; o estrangeiro apareceu sempre assim: demônio ou deusa" (BERMAN, 1984, 2012, p.277).

E então ele conclui, dizendo que tudo isso

faz pensar que a tradução se situa justamente nessa região obscura e perigosa, na qual a estranheza desmedida da obra estrangeira e sua língua corre o risco de se abater com toda a sua força sobre o texto do tradutor e sua língua, arruinando assim a sua empresa [...] Mas se esse perigo não for enfrentado, corre-se o risco de cair imediatamente em outro perigo: o de matar a dimensão do estrangeiro. A tarefa do tradutor consiste em enfrentar esse duplo perigo e, de uma certa maneira, em traçar ele próprio, sem nenhuma consideração pelo leitor, a linha divisória (BERMAN, 1984, 2012, p.278)

Levando em consideração que, ao realizar uma tradução, nos colocamos diante de uma escolha que deve ser feita de acordo com nossos propósitos, fizemos também neste trabalho de dissertação a nossa opção. O fato de termos como corpus uma obra de relevância histórica nos levou a optar por uma tradução que pudesse levar o leitor de hoje até a época em que ela foi escrita, procurando representar a organização linguística original e mostrar como o conteúdo científico foi tratado naquele momento (o século XIX) e naquele lugar (a França).

O interesse de um texto traduzido desta forma, a nosso ver, está em mostrar ao leitor de hoje um momento da pesquisa científica bastante diferente daquele que temos na atualidade, revelando, através dessa contextualização, a importância das reflexões de Claude Bernard na época em que elas foram elaboradas, enfatizando o cenário científico do século XIX. Seguindo a nomenclatura proposta por Venuti (1995), optamos por uma tradução estrangeirizadora, que podemos, então, justificar pelo fato já mencionado de se tratar de um texto científico de interesse histórico.

Em relação ao fato de entendermos o resultado do trabalho aqui apresentado como uma tradução estrangeirizadora, algumas críticas ou dúvidas podem ser levantadas. A primeira delas diria respeito à possibilidade de, pela estrangeirização, divulgar uma ciência, uma vez que, em princípio, a domesticação seria o procedimento mais plausível para isso. A esta questão, 
podemos responder que, em primeiro lugar, o objetivo principal do texto aqui traduzido não é o da divulgação da ciência. É claro que este texto, como qualquer texto traduzido, tem um papel importante na divulgação do conhecimento, algo que discutiremos com mais detalhes no próximo item deste trabalho. Porém, a divulgação da ciência neste caso não faria sentido como objetivo fundamental pelo fato de os conceitos presentes na obra do século XIX já terem sido assimilados plenamente pela comunidade científica e não apresentarem atualmente senão um interesse histórico - e não propriamente o de apresentação de conteúdos científicos. Sob esse aspecto, há ainda que se levar em consideração que a própria forma encontrada por Claude Bernard para expor os conceitos naquela época era bastante diferente daquela hoje aceita para um texto científico, aproximando-se, em certos aspectos estilísticos, mais dos textos literários do que dos científicos propriamente ditos.

O que acabamos de relatar parece ficar ainda mais evidente quando apontamos as características atualmente consideradas como desejáveis num texto científico e as comparamos ao que encontramos no texto de nosso corpus. Dentre as características consideradas importantes para um texto científico que podemos ressaltar temos que os mesmos devem ser impessoais, apresentar rigidez semântica para evitar redundâncias, ter uma linguagem que, desprovida de variação de estilo, não provoque efeito emocional (SOARES, 2011, p. 57-82). Muitas outras características são desejáveis, mas estas são suficientes para exemplificar o que desejamos apontar.

O texto de Claude Bernard tem um estilo bastante pessoal, com frases cujo efeito é claramente o de despertar algum efeito emocional no leitor, quando, por exemplo, ele defende de forma inegavelmente apaixonada seus argumentos. Sua linguagem não esconde em nenhum momento a subjetividade: ele se coloca em primeira pessoa, eliminando qualquer resquício de impessoalidade. Além disso, o uso do "je" (eu) também reitera o estado da Fisiologia Experimental em sua época, ainda em construção, e, consequentemente, a necessidade de escritos autorais, e, portanto, mais marcados, sobre o assunto. As características do texto científico de Bernard diferenciam-se, portanto, das dos dias atuais, o que justifica apresentá-lo de forma estrangeirizante ao leitor do século XXI. 
Ainda respondendo à primeira questão que foi colocada acima, um segundo aspecto que podemos levantar é o de que a opção de estrangeirização não se presta apenas à tradução literária, mas a qualquer outro tipo de tradução cuja escritura seja importante ou relevante. No caso de um texto científico do século XIX, com características estilísticas bastante peculiares, como já discutido nos parágrafos anteriores, atentar para esses detalhes revela-se, a nosso ver, algo significativo para o projeto de tradução.

Podemos tomar como exemplo o seguinte trecho da página 132, "Je suppose qu'un physiologiste veuille étudier la digestion et savoir ce qui se passe dans l'estomac d'un animal vivant $[. .]$.$" . A subjetividade e consequente autoria do texto aparecem de forma mais evidente$ em "je suppose". Um cientista de nossos dias escreveria, em francês, "supposons" (suponhamos) em lugar de "je suppose" (eu suponho).

Outro aspecto que julgamos importante ressaltar em relação às possíveis críticas sobre a opção de tradução por nós caracterizada como estrangeirizante é que, ao trazer um clássico do século XIX para o século XXI, atendemos aos três aspectos encontrados nas obras dos autores que nos servem de suporte teórico.

Em primeiro lugar, atendemos ao agir sobre a língua proposto por Shleiermacher (1813, 2007), uma vez que o estilo e o vocabulário do autor são trabalhados no discurso de tradução. Em segundo lugar, percorremos os vetores centralizadores ou descentralizadores dos caminhos que levam o século XXI para o XIX e vice-versa, nos termos de Berman (1984, 2012), e, finalmente, atuamos ética e politicamente, como diria Venuti (1995), ao colaborar com as lacunas tradutórias do país pela tradução de um clássico para a nossa língua.

Gostaríamos ainda de observar que se pode pensar que estrangeirizar um texto científico seja uma opção que acaba comprometendo conceitualmente seu conteúdo especializado. No entanto, além das características particulares do texto com o qual trabalhamos e que já foram apontadas acima, a terminologia científica não é tão presente nessa obra e, quando aparece na tradução, está devidamente estrangeirizada nas notas.

O que se constata é que, no caso de Claude Bernard, designações e conceitos não estavam tão cristalizados, estavam em construção. Um exemplo que podemos mencionar aqui é o do 
conceito de "meio interno", cujo processo de construção bastante longo foi abordado no capítulo 1, item 1.2 deste trabalho. É isso, na nossa opinião, que faz a beleza da estrangeirização desse texto, pois trata-se de uma questão discursiva e não terminológica (discutido numa seção de orientação, a ser desenvolvido posteriormente).

Ainda em relação à opção de tradução dita estrangeirizante, temos claro que uma crítica que pode ser feita é a de que as notas de tradução presentes no texto final teriam um papel contrário ao da escolha que propusemos, isto é, elas eliminariam a estranheza do texto, agindo como um fator mais domesticador do que estrangeirizante. Quanto a esta observação, a nossa convicção é a de que as notas que inserimos no texto traduzido fazem parte ou se inserem no gênero "tradução comentada", que abordaremos mais detalhadamente no Capítulo 3 (item 3.1.) deste trabalho, no qual fornecemos o suporte teórico correspondente.

Sob esse ponto de vista, as notas tornam-se, de algum modo, quase obrigatórias. Acreditamos que, seja no contexto acadêmico (no qual se insere nosso trabalho), seja no mercado editorial (no caso de termos esta tradução transformado em livro), as notas terão sempre o papel de levar o leitor de nossos dias ao contexto da época de Claude Bernard. Se elas não estivessem presentes nesse trabalho, talvez o leitor de hoje não se desse conta nem da distância temporal que separa o texto original do texto traduzido nem do gesto tradutório empreendido, num esforço por levá-lo ao contexto do autor.

As notas representam, a nosso ver, em última análise, todo o esforço realizado ao longo do processo tradutório para estrangeirizar o texto final, dando visibilidade ao tradutor, que age como um intermediário nessa viagem ao passado para mostrar ao leitor de hoje o que o texto tem de estranho ou exótico. 


\subsection{Tradução como difusão do conhecimento}

Sempre que se faz uma tradução, difunde-se, de alguma maneira um conhecimento. 0 que se pode observar ao longo de toda a história é que, desde que se esboçaram as primeiras tentativas de tradução, em tempos remotos, a difusão do conhecimento figurava como um de seus principais objetivos. A atividade tradutória tendeu sempre a cumprir esse papel, não apenas no que diz respeito à tradução científica, de que trata o presente trabalho, mas em todas as esferas do conhecimento humano.

Esteves (2014, p.75) compartilha desta ideia ao afirmar que

parece haver consenso no sentido de que a tradução tem como função primordial trazer para determinada língua uma informação que está escrita em outra. Podemos dizer, portanto, que a difusão de conhecimento depende, em grande medida, da tradução. Todas as ciências, sejam elas biológicas, humanas ou exatas, bem como todo o conhecimento por elas produzido foram ao longo dos séculos transmitidos entre culturas e, consequentemente, traduzidos.

No prefácio do livro Tradutores na História, Jean-François Joly (1998, p. 9) afirma que “a tradução é uma atividade que permeia todas as facetas da vida humana, e é também uma fonte inexaurível de progresso. " Joly traz uma série de exemplos de trabalhos de tradutores realizados ao longo dos séculos, em diversas áreas, no intuito de comprovar o papel desempenhado por essa atividade na difusão do conhecimento. Ele cita, por exemplo, o escravo grego Livius Andronicus, que traduziu "tesouros" da literatura helênica, assim como outros tantos tradutores que enriqueceram a cultura árabe com fábulas. Aponta ainda outros antigos tradutores que levaram essas mesmas fábulas para a Índia e também para a Inglaterra, ao longo dos séculos XIV ao XVIII. Especificamente no campo da ciência, o autor desse prefácio cita Jagannatha, astrônomo indiano do século XVIII que traduziu o Almagesto de Ptolomeu e também a obra Elementos, de Euclides, do árabe para o sânscrito. Émile du Châtelet também é lembrado, por ter sido "o primeiro a traduzir para o francês a obra de Newton" (JOLY, 1989, p.10). 
Concluindo o levantamento de uma longa série de exemplos históricos, Joly complementa o relato do percurso da tradução como transmissora de conhecimento com uma frase que revela toda a importância que essa atividade sempre teve, desde seus primeiros esboços: "A tradução tem a ver com a descoberta; é uma viagem de exploração pelo reino fabuloso do conhecimento" (JOLY, 1989, p.10).

Salama-Carr et al (1998, p.113) também compartilham da ideia de que a tradução sempre teve um papel bastante significativo na expansão do conhecimento humano ao longo da história. Dizem eles:

Desde a invenção da escrita, os povos procuram adquirir o conhecimento técnico e científico dos seus vizinhos, e nessa antiga busca pelo que era visto como informação útil as traduções ocuparam um espaço muito amplo. Não há dúvida de que esse processo de apropriação de descobertas alheias provocou a disseminação e o desenvolvimento da ciência e da tecnologia (SALAMA-CARR et al, 1998, p. 113).

Ainda em seu prefácio, apresentando a proposta da obra e ressaltando a importância de tal projeto, Joly (1989) nos lembra que a tradução sempre esteve presente na vida do homem, muito antes de existir uma entidade internacional que reunisse os responsáveis pela realização dessa tarefa. Segundo ele, "muito antes da FIT [Federação Internacional de Tradutores], os tradutores serviam como elos vitais na vasta cadeia de transmissão do conhecimento entre sociedades separadas por barreiras linguísticas. " (JOLY, 1989, p. 10). Ele enfatiza que a atividade de tradução, desde os tempos mais remotos, teve o importante papel de aproximar culturas e raças, nações e continentes, além de fazer uma ponte entre o passado e o presente, permitindo assim que obras científicas, filosóficas e literárias pudessem adquirir estatura universal. Este autor complementa sua visão sobre essa tarefa e sua contribuição para a difusão do conhecimento ao longo da história do homem dizendo que "os tradutores derrubam obstáculos criados pelas diferenças linguísticas, abrindo assim novos horizontes e ampliando nossa visão da realidade, de modo a abarcar todo o mundo" (JOLY, 1989, p. 10).

Ao apresentar o livro que ele prefacia, Joly (1989) ainda nos faz ver que muitos avanços nas civilizações humanas só foram possíveis ao longo da história graças a tradutores que 
contribuíram para o enriquecimento de línguas e para a disseminação de conhecimento técnico científico, que prepararam dicionários e que estimularam o surgimento de línguas nacionais. Ele afirma que " a tradução não pode ser dissociada da ideia do progresso; há mesmo quem sustente que uma sociedade pode ser avaliada pela qualidade das traduções que aceita, o que indica a importância do trabalho dos tradutores" (JOLY, 1989, p. 11).

Para Delisle e Woodsworth (1989), a contribuição dos tradutores na transmissão do conhecimento também pode ser observada nas pequenas transformações por eles efetuadas ao transportar o conteúdo de uma língua para outra. Eles consideram que desta forma os tradutores se transformam em agentes de mudanças que vão enriquecendo o conteúdo de cada obra traduzida e acrescentando passos no progresso do conhecimento. Segundo eles, esse papel realizado pelo tradutor é tão importante que sua contribuição "para a promoção do conhecimento, combinada com suas realizações nos campos da religião e da literatura, pode habilitar uma cultura a se descobrir" (DELISLE e WOODSWORTH, 1989, p.136).

Batalha e Pontes (2007) lembram que importantes autores, como Octavio Paz e Jacques Derrida, que tanto se preocuparam com questões de tradução, conferem à atividade tradutória um papel que a coloca no centro da atividade humana, até mesmo como responsável pelo avanço das civilizações. Esses autores ressaltam que culturas de outros povos foram levadas ou trazidas para outros países por meio de traduções. Houve momentos na história da civilização em que as traduções recebiam suporte financeiro de fontes abastadas, com o intuito de proporcionar o enriquecimento da própria língua, trazendo conhecimentos que se julgava mais adiantados. Foi o que aconteceu, por exemplo, na Europa, quando as literaturas ocidentais estavam sendo construídas e, "muitas vezes as traduções foram patrocinadas por monarcas poderosos, que viam aí a possibilidade de fortalecer e emancipar as línguas nacionais" (BATALHA e PONTES, 2007, p. 72).

O pesquisador francês Antoine Berman (1984, 2012, p. 328-329) vai mais além, aprofundando, a seu ver, ainda mais o papel da tradução na transmissão do conhecimento, colocando-a não só no centro da expansão do conhecimento científico, mas de todo o conhecimento transmitido pelo homem. Segundo ele, 
[...] a tradução, quer se trate de literatura, de filosofia ou até de ciências humanas, desempenha um papel que não é o de simples transmissão: esse papel, ao contrário, é tendencialmente constitutivo de toda literatura, de toda filosofia e de toda ciência humana. Giordano Bruno exprimiu-o com todo o lirismo próprio de sua época: Da tradução vem toda ciência (BERMAN, 1984, 2012, p. 328-329).

Também Venuti $(1989$, p.131) credita às traduções e às escolhas que são feitas pelos tradutores um importante papel naquilo que é transmitido aos diferentes povos, às diferentes culturas. Isso se evidencia na sua fala, quando ele diz acreditar que "a escolha calculada de um texto estrangeiro e da estratégia tradutória pode mudar ou consolidar cânones literários, paradigmas conceituais, metodologias de pesquisa, técnicas clínicas e práticas comerciais na cultura doméstica."

Embora reconheçamos o papel das traduções nas mais variadas áreas de atuação humana, como tentamos mostrar nos relatos acima, vamos aqui nos concentrar no seu papel relacionado especificamente à difusão do conhecimento científico, que teve e tem tido até os dias de hoje uma importância fundamental para o progresso das ciências em geral. Além disso, é nessa área do conhecimento que se enquadra o tema deste trabalho e no qual, doravante, iremos centrar nossa atenção. Salama-Carr et al (1989, p. 113-114) confirmam a importância da tradução na difusão do conhecimento científico ao citar Fischbach (1992), como vemos no trecho a seguir:

Nas palavras de Henri Fischbach, 'A tradução foi a chave do progresso científico, expondo sucessivamente a cada inventor ou descobridor o que pensavam seus predecessores, que tinham expressado ideias inovadoras em outra língua (1992, p. 194). Talvez mais do que qualquer outra modalidade, a tradução técnica e científica é um instrumento de fertilização cruzada, de transformação e progresso. Sem a tradução não haveria o fenômeno moderno da 'transferência de tecnologia'. Como disse Giordano Bruno (1548-1600), o filósofo italiano da Renascença, 'A tradução assegura a descendência de toda ciência'. Ela é uma fonte de inspiração, e não um fim em si mesma; estimula a reflexão e atua como um ponto de partida para a pesquisa ulterior. [...] Sem os tradutores, 'os grandes polinizadores da ciência' (Fischbach, 1992), esta não teria alcançado o status universal que tem hoje. 
De fato, todo o enfoque dos comentários acima centra sua atenção no importante papel da tradução na expansão do conhecimento científico, reconhecendo-a como peça-chave para que toda informação obtida por qualquer pesquisador, em qualquer língua, possa chegar a outros pesquisadores, dando continuidade ao processo de busca do conhecimento, numa verdadeira cadeia que permitiu à ciência atingir o atual estágio do conhecimento dos fenômenos da natureza. ${ }^{36}$ Esse depoimento adquire especial importância para o presente trabalho, uma vez que ele trata exatamente da tradução de um texto científico para outra língua, com o intuito de expandir o conhecimento ali contido e de tornar acessível a falantes do português brasileiro os conteúdos, não somente ali apresentados em francês, mas também naquela época.

Um fato importante que não podemos deixar de ressaltar neste momento é o de que, quando falamos em tradução científica, não podemos esquecer que esse tipo de texto envolve sempre uma terminologia própria do conteúdo abordado, o que torna esse tipo de tradução uma atividade que requer um maior ou menor conhecimento específico do conteúdo ali tratado. Muitas vezes, o tradutor se vê obrigado a forjar termos novos na sua língua e que devem estar de acordo com o conteúdo específico daquela dada área do conhecimento.

Delisle e Woodsworth (1989) nos lembram que, vista sob esse ponto de vista, a tradução se constitui num verdadeiro processo criativo, no qual a "língua da cultura-meta se beneficia com o trabalho dos tradutores, que precisam forjar novos termos para denotar os novos conceitos e realidade que encontram" (DELISLE e WOODSWORTH, 1989, p.136). Segundo eles, um exemplo bastante evidente desse papel criativo refere-se aos tradutores que, em Bagdá, em Toledo e na Europa medieval ajudaram a desenvolver uma linguagem científica nova por meio de empréstimos que faziam de outras línguas no seu procedimento de tradução.

Essa atitude levou a uma ampliação de recursos da língua nascente para a qual eles traduziam, acrescentando um registro erudito para o vernáculo. Os textos assim traduzidos iam pouco a pouco se integrando ao sistema linguístico e à cultura da língua meta e quanto mais isso se dava, mais esses textos eram difundidos. De acordo com esses autores, como resultado desse

\footnotetext{
${ }^{36}$ Hoje, a língua inglesa como língua franca desempenha, ao lado da tradução, também um papel significativo na difusão do conhecimento científico.
} 
processo, um conhecimento tão específico que antes só podia circular em meio a poucos eruditos, passou a contar gradativamente, graças à tradução e à criação de termos que se integraram à cultura e à língua de uma cultura receptora, com a possibilidade de ser difundido para um maior número de pessoas. Segundo eles, "assim o conhecimento ultrapassou o círculo estreito dos eruditos e dos especialistas, que tinham acesso às línguas da elite: o hebraico, o grego, o latim, o sânscrito" (DELISLE e WOODSWORTH, 1989, p.136).

O que eles constatam, portanto, com esse comentário é que toda tradução científica envolve um trabalho que lida com termos específicos de uma área, com uma terminologia própria do tema abordado e que, ao trabalhar com essa terminologia, os tradutores também desempenham, paralelamente, um importante papel na divulgação de ideias que podem alcançar não só os especialistas, como também não especialistas, ajudando a difundir ainda mais as informações ali contidas.

Abordaremos mais adiante, com mais detalhes, a questão específica da terminologia relacionada à tradução científica. Por ora, continuaremos ressaltando o papel da tradução científica na difusão do conhecimento.

Cristina de Amorim Machado (2014, p.240) acredita que toda circulação de conhecimento científico, seja ela literatura científica traduzida, divulgação/educação científica ou produção de conceitos científicos, sempre implica algum tipo de tradução. Ela compara esses três tipos de tradução, respectivamente, àqueles propostos por Jakobson (1959) e já citados anteriormente (cf item 2.1 desta dissertação). No caso do nosso trabalho, lidamos com o tipo que ela considera aquele que toma o sentido mais comum de tradução e que estaria relacionado ao de tradução interlingual. Segundo ela, este é o caso em que "vemos nos diversos livros de ciência traduzidos ao longo do tempo de/para as mais diversas línguas, desde a Antiguidade" (MACHADO, 2014, p.241).

Esteves (2014, p.77) também aborda a questão específica da tradução científica afirmando que há poucos estudos sobre a área que relacionem diretamente a história da ciência à história da tradução. No entanto, ela cita a obra Science in Translation, de Scott L. Montgomery, um geólogo interessado em "filosofia da ciência, história da ciência e o papel desempenhado 
pelas línguas na transmissão de textos científicos", dizendo que, desta obra, podem ser tirados alguns conceitos gerais a esse respeito:

- A tradução está envolvida em todos os níveis da produção e difusão do conhecimento nas ciências;

- Não há evidência de pesquisas consistentes sobre o que a tradução significou e significa para a história da ciência;

- É importante reconhecer o papel crucial da tradução na história do conhecimento científico (MONTGOMERY, 2000, p. ix-x, In ESTEVES, 2014p. 77).

O que podemos depreender dessas informações é que, embora não tenham sido realizadas muitas pesquisas que tratem especificamente do papel da tradução na história do conhecimento científico, não há como negar seu papel incontestável na transmissão desse conhecimento. É importante reconhecer que traduzir conteúdo científico significou ao longo de toda a história da humanidade, e ainda significa, dar ao outro o acesso a um conhecimento desenvolvido e apresentado em outra língua.

Esteves (2014, p. 103) considera, após cuidadoso levantamento em que trata do papel dos tradutores como sistematizadores e compiladores do conhecimento ao longo da história, que a tradução científica não só é importante na difusão de conhecimento, como ela também desempenhou um importante papel ligado aos interesses pessoais de diferentes civilizações, em diferentes épocas. De acordo com suas palavras,

[...] o ato tradutório de 'difusão do conhecimento' - o primeiro que nos vem à mente quando pensamos em tradução, aquele ato de proporcionar o acesso a um determinado conteúdo, acesso que anteriormente era negado (seja por tratar-se de um idioma desconhecido ou de termos técnicos especializados) pode envolver questões que vão muito além da difusão em si. Como conhecimento é poder, desde sempre a divulgação do conhecimento foi usada não só para proporcionar esse acesso, para ensinar pessoas, mas também para obter benefícios pessoais (ESTEVES, 2014, p.103).

Essa autora nos alerta, assim, para um aspecto que nem sempre é abordado, mas que não pode ser negligenciado quando tratamos de tradução científica: o de que traduzir conteúdo científico é algo que vai além da difusão de um conhecimento, pois ele traz à luz, em uma nova 
língua, conceitos novos, que podem proporcionar certo poder ou certa vantagem a quem os detém. Essa faceta permitiria ao tradutor, de certa forma, decidir quais tipos de conhecimento dividir, detendo com isso algum poder ou tirando disso alguma vantagem. Em outras palavras, a difusão do conhecimento é inegável, mas nem sempre o conhecimento assim difundido, ao longo da história, esteve isento de interesses daqueles que o traduziam. Essa opinião fica clara no trecho a seguir, onde ela afirma que

Nesta análise da primeira família dos atos de tradução, pudemos notar que, embora a difusão de conhecimento seja a função principal que o senso comum atribui à tradução, muitas questões foram levantadas em cada época e em cada contexto sobre como essa difusão de conhecimento deveria ou poderia ser feita. Mesmo no caso de textos que geralmente consideramos aproblemáticos do ponto de vista da tradução, houve desvios, alterações, distorções, acréscimos e várias outras formas de 'edição' que atualmente podemos considerar absurdas e desrespeitosas com o texto-fonte, mas que em outras épocas eram consideradas adequadas e até desejáveis" (ESTEVES, 2014, p.142).

Para finalizar, é importante observar que tivemos sempre em mente durante a realização do nosso trabalho que a tradução de conteúdo científico é um tipo de atividade que deve levar em conta os aspectos ligados ao tipo de conteúdo específico do texto em questão, tendo sempre clara a ideia de que traduzir ciência é uma atividade que desempenha importante papel na divulgação do conhecimento.

É exatamente isso que esperamos obter como resultado ao traduzir um texto cujo conteúdo traz conceitos que irão se tornar acessíveis a um novo público leitor, de uma língua diferente daquela na qual ele foi escrito e, além disso, em uma época diferente. Existe uma grande responsabilidade ligada ao ato de traduzir um texto desse tipo, divulgando as informações ali contidas de forma clara, para que elas possam ser úteis a um novo público leitor. Foi na realização dessa tarefa da melhor forma possível que nos empenhamos durante toda a execução deste trabalho. 


\subsection{Tradução científica e Terminologia}

Quando falamos de tradução científica ou técnica, adentramos um terreno que acaba se deparando e, muitas vezes se misturando, com uma outra área do conhecimento: a Terminologia. Embora essas duas áreas, Tradução e Terminologia, tenham objetivos e procedimentos diferentes, elas apresentam semelhanças e caminhos que acabam se entrecruzando nos seus procedimentos.

Segundo Krieger e Finatto (2004), uma explicação para isso é a de que os termos técnicocientíficos são elementos-chave dos textos especializados, o que consiste em uma primeira motivação para que o encontro entre Tradução e Terminologia. Segundo elas, "é em relação a essa tipologia textual que se efetua a chamada tradução técnica ou especializada" (KRIEGER e FINATTO, 2004, p.66).

Essas autoras ressaltam também que, ao realizar a tradução de textos técnico/científicos, o tradutor se vê inevitavelmente diante de um conjunto de termos que pertencem àquele campo de atuação ao qual se refere o texto. Segundo elas, "tal tipo de tradução, incidindo sobre textos especializados, habitat natural das terminologias, leva efetivamente os profissionais da tradução a se defrontarem com os léxicos temáticos [...]" (KRIEGER E FINATTO, 2004, p.66).

Ainda segundo Krieger e Finatto (2004, p.73), estes dois universos, o da Tradução e o da Terminologia, se aproximam cada vez mais e o reconhecimento deste fato leva a ampliar o diálogo entre essas duas áreas do conhecimento, articulando uma complementariedade, uma parceria, que se faz necessária para que se obtenha como resultado uma tradução técnica de boa qualidade.

Ramos (2001, p. 165-166) endossa a ideia de que Tradução e Terminologia são áreas que inevitavelmente se cruzam na prática tradutória de textos científicos, embora nem por isso se confundam, alertando para o fato de que é desejável que o tradutor, nesses casos, também domine, em alguma medida, o campo de conhecimento com o qual ele está trabalhando. De acordo com suas palavras: 
Ainda que seus interesses e objetos sejam diferenciados, os caminhos da Tradução e da Terminologia encontram seu ponto de intercessão na tradução de textos especializados. Sendo as linguagens de especialidade os instrumentos básicos de comunicação entre os especialistas, e a terminologia, o elemento mais importante para precisar cognitivamente seu sistema de denominação, é através delas que esses profissionais ordenam e transferem seu conhecimento. Para expressar de modo adequado a mensagem emitida em outra língua, caberá ao tradutor munir-se de uma competência paralela à do especialista, transpondo-a precisa e adequadamente (RAMOS, 2001, p.165-166).

Esta última observação nos interessa de forma especial, pois ressalta a importância de que a tradução de nosso corpus, um texto de Fisiologia, tenha sido realizada por alguém que apresenta uma dupla formação, na área de Letras (Francês) e na de Biologia. No entanto, isto não é uma regra. Em geral, o tradutor de textos científicos se torna, pouco a pouco, em alguma medida, um especialista de uma determinada área do conhecimento. Ou seja, pela prática, o tradutor especializa-se. Porém, o contrário também se observa: o especialista de determinada área do conhecimento pode também tornar-se um especialista na tradução desse domínio.

Não é por acaso, pelo que foi acima exposto, que as origens da Terminologia, como disciplina ou como uma área do conhecimento, tenham ocorrido a partir da prática de tradução de textos especializados. Krieger (2001) lembra, a esse respeito, as palavras de Cabré:

A terminologia e a tradução surgiram ambas da prática, da necessidade de expressar um pensamento especializado ou de resolver um problema de compreensão. A terminologia como atividade consciente surgiu do interesse dos cientistas em se colocarem de acordo sobre a fixação dos conceitos e denominações de suas respectivas ciências, sobretudo, as ciências naturais. Logo após os cientistas apareceram os técnicos, ante a necessidade de se por de acordo sobre os termos das inovações industriais e tecnológicas. A tradução nasceu diante da necessidade de facilitar a compreensão entre línguas distintas, uma necessidade comunicativa evidente (Cabré, 1999, apud KRIEGER, 2001, p.158).

Mas, como nos lembra Krieger (2001, p.157), apesar de esses campos do conhecimento se entrecruzarem e de muitas vezes se confundirem em sua prática, o que o tradutor faz não é Terminologia. Ela diz que existe uma grande distinção entre terminologia e tradução, o que fica evidente quando observamos os objetos dos estudos terminológicos, uma vez que os seus 
campos de estudo diferem no que diz respeito ao conhecimento envolvido e aos propósitos. De acordo com suas palavras,

Muito embora para o tradutor técnico seja fundamental conhecer a terminologia da área, bem como o conhecimento da fraseologia, expressões e frases utilizadas numa determinada área do conhecimento lhe é de suma importância, o que ele faz não é terminologia. Interessa-lhe a tradução adequada e o tratamento correto do termo e das fraseologias. Desse modo, fazer tradução e fazer Terminologia são campos distintos do conhecimento e de atuação, apesar de suas zonas de confluência (KRIEGER, 2001, p.157).

Estas observações nos mostram mais uma vez o quanto é importante que o tradutor de textos científicos detenha um mínimo conhecimento da área sobre a qual trata o texto, uma vez que o mesmo se defrontará inevitavelmente com termos que não fazem parte da linguagem comum, de uma maneira geral, mas que pertencem àquela área de especialidade. Quanto mais conhecimento ele tiver a respeito da área na qual se insere seu texto, mais confiável será sua tradução, no que se refere à precisão conceitual.

Aubert (2001, p.42) também fala sobre a intersecção entre Tradução e Terminologia, dizendo que essa relação é bastante antiga, uma vez que desde tempos remotos, toda vez que um texto científico ou técnico era traduzido, uma lista de termos acabava sendo inevitavelmente levantada. Mas ele discute que a relação existente entre tradutores e terminológos pode ser considerada tanto positiva como negativa, dependendo do ponto de vista ou da direção que a tarefa assume, como podemos verificar por suas palavras no trecho abaixo:

A relação entre a terminologia e a tradução técnico-científica não é apenas antiga, no sentido de que a necessidade da tradução técnico-científica induziu e induz, até hoje, a uma elevada produção de materiais terminológicos. Esta relação também se caracteriza, na percepção de seus respectivos praticantes, como positiva na direção da terminologia à tradução e, no geral, como negativa na direção da tradução à terminologia. Na direção positiva, a terminologia e a terminografia são vistas como ferramentas essenciais, provedoras que são de informações para o exercício da atividade tradutória nos domínios científico e técnico [...]. De fato, os tradutores provavelmente constituem um dos principais grupos de usuários de fontes terminológicas de todo tipo - inclusive dos materiais terminográficos monolíngues (AUBERT, 2001, p.42). 
Como vimos acima, esse autor considera positivo o fato de tradutores poderem se valer de termos que constam da terminologia para efetuarem suas traduções. No entanto, um lado negativo ocorreria no sentido contrário, isto é, da tradução para a terminologia, quando o tradutor levanta termos encontrados em seu texto fonte e os traduz. Essas críticas são justificadas, segundo esse mesmo autor, pois muitas vezes, por não estarem plenamente preparados para a tarefa de traduzir um texto contendo termos específicos de uma determinada área, os tradutores podem acabar criando termos novos ou improvisando, como diz ele, "de maneira desastrada". Ele pondera que na relação tradução $\rightarrow$ terminologia, muitas vezes os tradutores são vistos como criadores de neologismos, improvisando termos que nem sempre são o resultado de grande inspiração. Como consequência, ele aponta que o que ocorre é a

expansão por vezes descontrolada de sinonímias e parassinonímias, no aprofundamento das discrepâncias entre os dialetos institucionais, para não dizer na cristalização de formas lexicais, morfossintáticas e mesmo textuais decalcadas na estrutura da língua-fonte e, portanto, idiomaticamente insatisfatórias" (AUBERT, 2001, p.44).

Mais uma vez fica evidente a responsabilidade do tradutor de textos científicos em compreender e dominar, pelo menos em certa medida, a terminologia da área na qual se insere o texto a ser traduzido, a fim de ser capaz de realizar uma tradução competente e confiável para os profissionais da área à qual se destina.

Ao falarmos de terminologia, com " $\mathrm{t}$ " maiúsculo, designando a ciência nos parágrafos precedentes, nos referíamos algumas vezes ao conjunto de termos de uma área, terminologia com " $\mathrm{t}$ " minúsculo, mas também falamos em uma disciplina que interage com outra disciplina, a Tradução, diferença esta que geralmente se evidencia pelo contexto. Isto advém do fato de que Terminologia pode ser conceituada de diferentes formas e julgamos importante ressaltar aqui quais são os conceitos, atualmente aceitos para esse termo. Trata-se, na verdade, de um termo que, segundo Krieger (2001, p.156), "evoca diferentes conceituações, a despeito do reconhecimento de que o ideal de expressão de um termo técnico-científico é o de que ele 
circunscreva um único conceito dentro de uma área de especialidade". Esta autora admite para Terminologia pelo menos três formas diferentes de conceituação. São elas:

- É o conjunto dos termos de um domínio, como por exemplo, física, química, linguística (cf. Rondeau, 1984, p.18).

- É a disciplina ou ciência que estuda os termos, sua formação, seus usos, suas significações, sua evolução, suas relações com o universo percebido ou concebido (Gouadec, 1990, p.3).

- Ao mesmo tempo, a Terminologia é um campo de conhecimento que oferece os fundamentos teóricos e metodológicos para a terminografia, ou seja, para a produção de instrumentos de referência especializada, como glossários, dicionários técnicos, bancos de dados terminológicos.

Para, Krieger (2001), dentre esses três conceitos, o que mais se aplica ao trabalho do tradutor de um texto científico é o primeiro deles, ou seja, terminologia com "t" minúsculo. Segundo ela, os tradutores se interessam pela terminologia, principalmente como o conjunto de termos da área específica a que pertence o texto sobre o qual eles trabalham. Assim, segundo ela, o que importa para esse profissional é a "sua própria competência no manejo terminológico, dada a necessidade de estabelecer adequadamente os equivalentes da terminologia presente no seu texto de partida" (KRIEGER, 2001, p.157).

No caso específico do nosso trabalho, a terminologia com a qual trabalhamos é o conjunto de termos da Fisiologia e/ou Medicina encontrados no texto-fonte, como aponta a autora acima citada. Mas não podemos esquecer também da Terminologia como o campo de conhecimento de cuja metodologia nos valemos para reunir ou organizar os termos específicos do nosso corpus. Conhecer e identificar esses termos é tarefa imprescindível para a realização do trabalho que aqui propomos. Além disso, reconhecer uma terminologia específica de um texto científico é um valioso auxílio na tarefa de tradução, visando tornar o mais claro possível o texto traduzido.

Como área de conhecimento, a Terminologia (doravante escrita com letra maiúscula, quando nos referirmos a esse conceito em particular) é, na verdade, uma disciplina muito antiga. Rondeau (1984, p.1) lembra quão antiga ela pode ser considerada ao afirmar: 
A terminologia não é um fenômeno recente. Com efeito, tão longe quanto se remonte na história do homem, desde que se manifesta a linguagem, nos encontramos em presença de línguas de especialidade, é assim que se encontra a terminologia dos filósofos gregos, a língua de negócios dos comerciantes cretas, os vocábulos especializados da arte militar, etc. (Rondeau, 1984, apud KRIEGER E FINATTO, 2004, p.24) $)^{37}$

Tomando a Terminologia como campo do conhecimento, é importante ainda reconhecer, pelas abordagens atuais, que ela não trabalha sozinha, mas, na verdade, trata-se de uma disciplina que se relaciona a outras, atuando com elas em conjunto. Como afirma Cabré (1999, p.70): “A terminologia é uma matéria de caráter interdisciplinar, integrada por fundamentos provenientes das ciências da linguagem, das ciências cognitivas e das ciências sociais."

Cabré $(1999$, p.72) também lembra que a Terminologia surge da prática no caso dos textos científicos, pois ela resulta da necessidade de técnicos e cientistas em denominar e normalizar conceitualmente suas disciplinas, a fim de garantir uma comunicação profissional e uma transferência de conhecimentos eficientes.

Esta observação se reveste de especial importância para o nosso trabalho (cf. Capítulo 1 desta dissertação), pois em nosso texto de partida, a Fisiologia ${ }^{38}$ ali exposta nasce da prática científica de Claude Bernard e, com ela, a terminologia por ele proposta, esta última, aqui entendida no sentido de um conjunto de termos específicos da área.

Para entendermos a importância do que acabamos de apontar acima, lembramos que Krieger e Finatto $(2004$, p.20) consideram a Terminologia como uma disciplina que possui seu objeto primordial definido - o termo técnico-científico - e que esse objeto marca a identidade da área. Elas apontam também que fraseologia especializada e definição terminológica também

\footnotetext{
37 Não nos foi possível ter acesso à obra original, razão pela qual mantivemos a citação, que julgamos bastante pertinente, a partir de outra obra consultada.

${ }^{38}$ A Fisiologia é uma área específica da Biologia, que trata do funcionamento dos organismos, isto é, da maneira como se comportam seus órgãos e sistemas no desempenho de seus processos vitais. Trata-se de uma disciplina cujo nascimento como disciplina experimental é em grande parte atribuído aos trabalhos desenvolvidos por Claude Bernard. Não por acaso, ele é considerado o pai da Fisiologia Moderna, pois, embora já se fizessem estudos em Fisiologia na sua época e a disciplina já fosse estudada por outros estudiosos, foi a partir de seus trabalhos, no século $X I X$, que foi introduzida a experimentação, criando o que ele defendia como uma Fisiologia Experimental.
} 
integram hoje o campo de pesquisa dessa disciplina, mas ainda mantendo o termo científico como seu foco principal.

Krieger e Finatto (2004, p.20) lembram que suas bases foram estabelecidas por Eugen Wüster (1898-1977), engenheiro austríaco que a introduziu na Universidade de Viena em 1972. Elas descrevem assim o que foi por ele proposto e que é considerado o nascimento documentado da Terminologia como área do conhecimento, com a criação de uma teoria que recebeu o nome de Teoria Geral da Terminologia:

Com a preocupação de padronizar o uso de termos técnico-científicos de modo a alcançar a univocidade comunicacional no plano internacional, [Wüster] desenvolveu uma série de estudos sobre os termos que deram origem à Teoria Geral da Terminologia (TGT). Por isto Wüster é considerado o fundador da Terminologia moderna, tendo-a concebido como uma disciplina autônoma e multidisciplinar, situada na convergência da linguística, da lógica, da ontologia, das ciências da informação e das diferentes áreas do conhecimento científico. [...]Para Wüster, a terminologia de uma área é, em sua natureza, a expressão de um conhecimento científico, logicamente estruturado. Nesse sentido, os termos refletem fundamentos conceituais, bem como representam a apreensão da essência dos fenômenos estudados pelas especializações (KRIEGER E FINATTO, 2004, p.20).

Reunindo vários campos do conhecimento, Wüster propôs uma disciplina fundamentada no aspecto prático de padronizar os termos usados em determinada área, facilitando a comunicação entre as pessoas envolvidas nesses meios e para quem era importante a troca de dados da forma mais clara possível.

Anos mais tarde, Cabré (1999) propôs sua abordagem para a Terminologia, por considerar que, como outros teóricos que propuseram outras abordagens a partir de outros olhares ${ }^{39}$, a

\footnotetext{
${ }^{39}$ Vários autores propuseram outras abordagens para a Terminologia, estudando-a através de outros enfoques. Entre eles, podemos citar Francois Gaudin que, com a Socioterminologia trouxe uma abordagem sociolinguística para esta área do conhecimento (GAUDIN, François. La socioterminologie. In: Langages, 39e année, $n^{\circ} 157,2005$. La terminologie: nature et enjeux. pp. 80-92. Disponivel em: /web/revues/home/prescript/article/lgge 0458726x 2005 num 39157 976). Citamos também Maria Aparecida Barbosa, que propôs a Etnoterminologia (BARBOSA, M.A. Para uma etno-terminologia:Recortes epistemológicos. Revista Ciência e Cultura, v.58, n.2, p.4851, 2006. Disponivel: em http://cienciaecultura.bvs.br/pdf/cic/v58n2/a18v58n2.pdf) e Rita Temmerman, com a
} 
chamada Teoria Geral da Terminologia proposta por Wüster apresentava limitações. A essa nova abordagem ela deu o nome de Teoria Comunicativa da Terminologia (TCT) e as razões que a levaram a essa reformulação podem ser compreendidas pelas suas próprias palavras, transcritas abaixo:

[...] hoje a proposta de Wüster é objeto de revisão por parte de muitos especialistas em terminologia, já que, por seu caráter reducionista e idealista, a consideram insuficiente para dar conta das unidades terminológicas dentro de um marco comunicativo plural. O reducionismo e idealismo desta teoria são confirmados tanto pela concepção global da unidade terminológica como por sua limitação a uma condição denominativa, com todas as consequências que ele supõe [...] A TGT se baseia numa suposta homogeneidade e universalidade do conhecimento especializado e no desejo de unificação das formas de expressão, que não confirmam os dados empíricos, com exceção de alguns poucos âmbitos. (CABRÉ, 1999, p.110-111, Tradução nossa)

Assim, Cabré introduz um conceito comunicativo para o termo, que, segundo ela, apresenta um caráter poliédrico por ser, "ao mesmo tempo, uma unidade linguística, uma unidade cognitiva e uma unidade sociocultural" (1999, p. 70, tradução nossa).

Assumindo a poliedricidade do termo, Cabré (1999) leva em conta a possibilidade de que uma mesma unidade lexical possa assumir diferentes funções em diferentes contextos, o que é coerente com nosso trabalho, uma vez que seu objeto de interesse é um texto científico histórico, permeado de reflexões realizadas pelo autor ao apresentar e/ou defender suas ideias muitas vezes pautadas em discurso que, talvez atualmente, não fosse considerado como tal. Em outras palavras, o texto de Claude Bernard é um texto bastante expressivo, uma vez que ele utiliza uma linguagem mais informal, muitas vezes contando histórias de fatos ocorridos com cientistas que o antecederam ou mesmo com seus contemporâneos.

Esse tipo de texto difere bastante dos textos científicos atuais, pois não traz a mesma linguagem científica objetiva destes últimos. Sua linguagem é bastante subjetiva, muitas vezes até dirigida diretamente às pessoas de quem ele fala; trata-se de um texto em conformidade com a época em que foi escrito, época em que viveu este estudioso da ciência, quando a forma de

teoria cognitiva (TEMMERMAN, Rita. Towards News Ways of Terminology Description: The Sociocognitive Approach. Amsterdam Philadelphia: John Benjamins, 2000). 
escrever cientificamente era bastante diferente da atual e permitia esse tipo de linguagem que hoje seria considerada uma linguagem sem o necessário rigor científico. ${ }^{40}$

Zavaglia et al (2010) ressaltam a importância de se levar em conta o viés comunicativo introduzido por Cabré na abordagem das terminologias e o fato de que muitas vezes os termos específicos de uma determinada área não se restringem apenas à ciência, mas podem ser encontrados também em situações de língua de uso geral. Como o texto que nos serve de corpus traz uma nuance de texto científico amalgamado a uma linguagem comum, a poliedricidade do termo é algo que devemos ter em mente ao lidar com ele e efetuar sua tradução. As autoras colocam assim essas duas questões:

[...] passadas algumas décadas da criação da Terminologia geral wüsteriana, o domínio vem sofrendo uma revisão por parte dos especialistas, uma vez que hoje a proposta de Wüster é vista como reducionista e idealista, com pressupostos insuficientes para dar conta das unidades terminológicas dentro do panorama comunicativo plural atual (ZAVAGLIA et al, 2010, p.20-21).

Ainda nesse texto, as autoras lembram que, como já havia sido observado por Cabré (1999), em situações profissionais reais, frequentemente podem ser observadas características que coincidem com as das situações de uso da língua geral, situações essas em que "as unidades terminológicas compartilham elementos com as unidades da linguagem natural e de outros sistemas simbólicos não linguísticos" (ZAVAGLIA et al, 2010, p.20-21). É desta forma que se abre a possibilidade de uma descrição dos termos a partir de uma teoria de bases menos restritiva ou, ainda segunda as autoras, em outras palavras, "não seria possível excluir da abordagem terminológica a comunicação e a cognição, uma vez que as terminologias organizam-se no

\footnotetext{
${ }^{40} \mathrm{O}$ que se considera hoje como um texto científico de linguagem adequada é aquele que traz uma rigidez semântica que vise evitar redundâncias e também aquele que recorra a uma simplificação da sintaxe. Sugere-se ainda que esse tipo de texto deva trazer poucos verbos, por se tratar de um tipo de linguagem que não deve provocar efeito emocional, apresentando-se assim sob a forma de estrutura desprovida de variação de estilo. Mais informações a respeito das características de um texto científico na atualidade podem ser encontradas em BRAGA, S.A.M. e MORTIMER, E.F. Os Gêneros do Discurso do Texto de Biologia dos Livros Didáticos de Ciências. Revista Brasileira de Pesquisa em Educação em Ciências, v.3, n.3, pp. 56-74, 2003, disponível em http://revistas.if.usp.br/rbpec/article/view/150/135 e também em GOUVÊA, G.S. A Divulgação Científica para Crianças: o caso da Ciência Hoje das Crianças. Rio de Janeiro: Tese de Doutorado, CCS/UFRJ, 2000).
} 
discurso e sofrem as mesmas alterações e mudanças verificadas no léxico da língua geral" (ZAVAGLIA et al, 2010, p.20-21).

Fica claro a partir do acima exposto o quanto a tarefa do tradutor de textos especializados é delicada. Krieger e Finatto (2004) comentam a esse respeito:

Ao enfrentarem uma série de requisitos textuais para uma prática competente, os tradutores compreendem que os termos técnicos e científicos consistem numa forma de expressão própria da comunicação profissional, possibilitando que sejam objetivamente veiculados conceitos próprios de uma área. É nessa medida que os termos configuram-se como elementos linguísticos de representação e de divulgação do conhecimento, além de funcionarem como recurso para conferir univocidade e, consequentemente, eficácia à comunicação entre especialistas (KRIEGER E FINATTO, 2004:66).

A correta comunicação dos conceitos veiculados, portanto, deve ser um ponto extremamente importante a ser considerado na tradução do texto científico. Uma tradução adequada de textos desse tipo será aquela capaz de transmitir informações com a maior correção conceitual possível, uma vez que textos desse tipo se destinam a circular entre especialistas de uma área do conhecimento na qual a comunicação clara é imprescindível.

Krieger (2006, p. 190) também aponta essa necessidade, afirmando que

O emprego correto de termos técnico-científicos contribui para o alcance da precisão semântico-conceitual que toda tradução de texto especializado obrigatoriamente requer, conferindo também ao texto de chegada grande parte das características expressivas comumente usadas pelos profissionais do mesmo campo de atuação (KRIEGER, 2006 p. 190).

É importante lembrar aqui que cada área da ciência tem uma forma diferente de se expressar, com suas características particulares, que a identificam do ponto de vista do discurso e do gênero. No caso do nosso trabalho, apesar de se exigir atualmente, para esse tipo de texto, uma linguagem isenta de qualquer subjetividade, temos que levar em conta que o que temos no século XIX, época na qual foi escrita a obra que nos serve de corpus, é uma forma de expressão 
bastante diferente daquela utilizada atualmente nessa área, o que resulta em mais um parâmetro a ser levado em conta no fazer tradutório que foi levado a cabo neste trabalho.

Vale ainda lembrar que uma outra forma de caracterizar um texto científico é a densidade de termos especializados que ele carrega: quanto maior a quantidade de termos específicos de uma área, mais o texto pode ser caraterizado como científico ou especializado. Um texto literário, por exemplo, irá sempre apresentar uma menor densidade de termos especializados e, mesmo que ele trate de um assunto específico, como alguma forma de ciência, a densidade de termos que ele trará será sempre menos do que aquela encontrada no texto científico propriamente dito.

No caso do texto de Claude Bernard, acaba sendo difícil dizer, desse ponto de vista, se o texto é ou não especializado, devido às reflexões sobre a prática científica e sobre o estado da ciência naquele momento. No entanto, podemos dizer que a densidade de seu texto se faz no próprio discurso, à medida em que ele desenvolve os conceitos, em meio a histórias ou reflexões.

Na verdade, ao longo de nossa tradução de um texto do século XIX, um fato ao que tivemos que atentar foi o de que muitas vezes a fronteira que se estabelece entre os chamados discurso comum e discurso especializado pode não se apresentar tão claramente estabelecida. A tarefa de traduzir um texto "especializado especial", como é o nosso caso, segundo o que foi levantado pelos autores acima destacados, configura-se como um trabalho que exige do tradutor uma preocupação também especial e que, de certa forma se beneficia quanto maior o conhecimento do mesmo com relação à área com a qual ele trabalha.

Patricia Chittoni Ramos (2001, p.168) trata este tradutor como, de certa forma, também um especialista e ressalta assim a sua importância:

As linguagens de especialidade são, portanto, os instrumentos de comunicação entre os especialistas, que precisam cognitivamente seu sistema de denominação através da terminologia. Sendo a terminologia a base de comunicação entre os especialistas, cabe ao tradutor especializado, que atua como mediador entre o especialista do texto de partida e o receptor do texto de chegada, converter-se igualmente em especialista. Em outros termos, um tradutor técnico deverá adquirir um efetivo conhecimento especializado para 
realizar com segurança sua atividade de seleção dos termos e da fraseologia termos da área que traduz.

Tendo em mente todos esses aspectos, procuramos levar a cabo uma tarefa de tradução que pudesse trazer aos dias de hoje a importância história do momento em que ela foi escrita, sendo também capaz de estabelecer uma adequada comunicação entre os especialistas da área interessados em compreender hoje como nasceram importantes conceitos cujo valor é reconhecido atualmente dentro deste campo da Biologia. 


\section{CAPÍTULO 3: TRADUÇÃO COMENTADA}

O espírito verdadeiramente científico deveria nos tornar modestos e benevolentes. Na verdade, todos nós só sabemos bem algumas poucas coisas e todos somos faliveis diante das dificuldades imensas que nos apresenta a investigação dos fenômenos naturais.

Claude Bernard

\subsection{Por que tradução comentada}

O projeto que deu origem a este trabalho visou à tradução de um texto clássico, de importância histórica reconhecida para a área da Biologia (particularmente a Fisiologia), por refletir parte de sua história. Uma vez que o texto original trazia informações que hoje podem não ser muito bem compreendidas, devido ao lapso de tempo transcorrido e aos avanços observados nessa área do conhecimento científico, constatamos que seria imprescindível apontar, ao longo do texto traduzido, todos os pontos que pudessem demandar explicações ou esclarecimentos que contribuíssem para o melhor entendimento do texto do século XIX para os leitores do século XXI.

Além de ressaltar os aspectos históricos ligados à Biologia, notamos também que seria algumas vezes necessário introduzir notas explicativas para temas relacionados à Filosofia, por conta das reflexões do autor ao longo de toda a obra, nas quais ele questiona as formas de buscar o conhecimento em Biologia e que, por isso, despertam o interesse dos estudiosos da Epistemologia. Além disso, por se tratar de um trabalho que se insere nos Estudos da Tradução, julgamos também evidente a inserção de reflexões sobre as questões de tradução e as opções e caminhos escolhidos.

Por essa razão, procuramos saber como realizar esse tipo de tarefa, pesquisando a existência de outros projetos semelhantes. Nos títulos de publicações acadêmicas, assim como nas dissertações e teses que pudemos levantar, duas denominações são frequentemente encontradas: "tradução comentada" e "tradução anotada". Pudemos verificar na literatura a 
esse respeito que ambas foram apontadas por Williams e Chesterman (2002) em sua obra The Map, em que são tratadas como formas alternativas de nomear esse processo. Segundo eles, "uma tradução com comentários (ou tradução anotada) é uma forma de pesquisa introspectiva e retrospectiva em que o tradutor traduz um texto e, ao mesmo tempo, escreve um comentário a respeito de seu processo de tradução" (Williams e Chesterman, 2002, p.7, tradução nossa, parênteses dos autores).

Percebe-se na citação anterior que os autores tratam "tradução com comentários" como sinônimo de "tradução anotada", este último tipo, que aparece entre parênteses, como explicação do primeiro. Desse modo, eles não diferenciam uma da outra. Ao explicar o que seria uma tradução desse tipo, os autores acrescentam que os comentários apresentados pelo tradutor podem aparecer de diferentes formas, entre as quais, discussões sobre a tarefa de traduzir, análise do texto-fonte e do contexto em que ele foi escrito ou ainda justificativas sobre o tipo de problemas enfrentados e soluções para eles propostas, no decorrer do processo tradutório.

Em um levantamento na literatura, pudemos observar que há uma preferência pela denominação "tradução comentada", pois ela parece ser mais abrangente, uma vez que podemos assim chamar toda tradução que traga comentários do tradutor, seja na forma de notas ou em capítulos a eles especialmente dedicados. Quando falamos em "tradução anotada", a impressão que se tem é a de que os comentários a respeito do processo tradutório não poderão ser apresentados senão na forma de notas, porém, não é o que acontece na realidade. Em outros casos, alguns autores usam até mesmo as duas denominações, dando a seus trabalhos o título de "tradução anotada e comentada".

Em 2007, a revista francesa Palimpsestes dedicou um volume especial ao tema da tradução comentada. Na apresentação desse volume, Maryvonne Boisseau comenta que existem várias formas de se comentar um trabalho de tradução e que comentários sempre estão presentes numa tradução, seja de forma implícita ou de forma explícita. Implicitamente, ela afirma que qualquer tradução guarda em seu resultado algum traço do que seria, afinal, o comentário do tradutor, já que ela é carregada de pressupostos mais ou menos conscientes da 
interpretação que ele exprime. De acordo com suas palavras, o enunciado traduzido "apresenta ao mesmo tempo vestígios do comentário que precede sua enunciação e os vestígios que o colocam em relação com circunstâncias particulares dessa enunciação: contexto histórico, cultural, linguístico" (BOISSEAU, 2007, p.2, tradução nossa).

Em outras palavras, a autora entende que as escolhas conscientes de um tradutor, suas interpretações, podem ser entendidos como comentários inseridos no produto final de seu trabalho, que é a tradução. Ainda segundo essa autora "seja explícito ou implícito, confesso ou inconfesso, o comentário é, sem dúvida um efeito que se constitui numa verdadeira estratégia [de tradução] " (BOISSEAU, 2007, p.3, tradução nossa).

Referindo-se aos comentários explícitos, Boisseau (2007, p.4) considera que estes podem ter uma função explicativa, quando, por meio deles, o tradutor esclarece quais foram as decisões que ele tomou ao longo do processo tradutório, ressaltando que eles podem aparecer sob a forma de diferentes peritextos, dependendo das estratégias escolhidas. Como exemplo, ela cita o caso de prefácios e posfácios escritos pelo tradutor, nos quais ele pode explicar suas estratégias de tradução e os caminhos que ele decidiu seguir ou nos quais ele pode ainda situar o contexto histórico da obra trabalhada e a importância do autor da obra original. Segundo ela, "prefácios e posfácios são também comentários autônomos sobre o texto original e/ou sua tradução, sobre o elo que os une apesar da diferença linguística" (BOISSEAU, 2007, p.5, tradução nossa).

Além de prefácios e posfácios, Boisseau (2007, p.4) cita uma outra forma de apresentar comentários em forma de peritexto: as notas de rodapé, que ela considera uma forma “abertamente didática" de apresentar comentários e que também podem ser necessárias para abrir um espaço para a teorização do traduzir. Segundo ela, ainda nesse mesmo trecho de sua apresentação, as notas de rodapé acabam lembrando o leitor que o que ele lê é uma tradução e interrompem sutilmente sua leitura, razão pela qual podem não ser bem vistas por alguns leitores. Na verdade, ao desempenhar sua função, elas acabam, segundo ela, tornando-se inevitavelmente um prolongamento do texto, tornando o tradutor essencialmente visível. 
Sardin (2007) afirma, a esse respeito, que "as notas nos lembram que a tradução é um jogo de escritura(s) de regras nunca estabelecidas, sempre negociáveis e que é polêmica em sua essência" (SARDIN, 2007, p.2).

Entre os tipos de tradução apresentados por Boisseau $(2007$, p.5) sob a denominação geral de tradução comentada, as traduções bilíngues são citadas como uma forma importante de permitir ao leitor a confrontação dos textos fonte e meta. Ela comenta que uma edição bilíngue tem também o papel de evidenciar, ao mesmo tempo, o lugar do comentador, do pesquisador e do tradutor, os mesmos que também realizam, de outra forma, prefácios e posfácios.

Segundo Karas (2007, p.2), a tradução bilíngue é uma forma de apresentação que interessa aos estudiosos da tradução e que revela a consciência do tradutor de que é possível haver discrepâncias entre os dois textos, acrescentando que, ao apresentar os dois textos lado a lado, o tradutor revela suas estratégias e suas escolhas ao leitor que os compara. No caso do trabalho citado, são examinadas três traduções intralinguais (do francês antigo para o moderno) - chamadas por ela de traduções bilíngues - de um mesmo original delas distante no tempo e no espaço, com objetivos pedagógicos. Mesmo que nosso trabalho apresente uma tradução interlingual (do francês para o português) com outros objetivos, como veremos adiante, um dos aspectos levados em consideração ao tomarmos a decisão de como apresentar nossa tradução, ou seja, ao lado do original, foi o de explicitar a diferença espaço-temporal que separa um texto do outro.

Pouco tempo depois da publicação francesa de um volume dedicado especialmente às traduções comentadas ao qual eles deram o título De la traduction comme commentaire au commentaire de la traduction (Da tradução como comentário ao comentário da tradução), tivemos também aqui no Brasil uma publicação especialmente dedicada a esse tema. No volume da revista Scientia Traductionis, que lança um espaço específico para essas publicações, seus editores Furlan e Althoff (2010, p.35) ressaltam, ao apresentar esse espaço editorial, que a importância desse tipo de tradução reside no fato de a mesma evidenciar as reflexões do tradutor sobre a tarefa que ele empreende. Nesse volume e em volumes posteriores são apresentados 
muitos trabalhos que nos ajudaram a definir os parâmetros que iríamos estabelecer para o nosso próprio trabalho.

Uma coisa que nos pareceu evidente em todas as leituras levantadas foi que não há para esse tipo de trabalho uma única maneira padronizada de se trabalhar. Muitos tipos de trabalho, com várias formas diferentes de apresentar comentários, podem fazer parte do universo das chamadas traduções comentadas. Resolvemos, então, escolher um caminho para o nosso trabalho, uma forma de apresentação que, com base em tudo o que vimos como possibilidade de comentar uma tradução, nos pareceu a forma mais coerente para tirar do nosso corpus o maior proveito possível.

A solução que nos pareceu a mais adequada foi a de apresentar uma tradução bilíngue com notas relacionadas aos possíveis questionamentos e reflexões que fomos encontrando ao longo de todo o processo de tradução. Ao levantar as notas, nos demos conta de que elas poderiam e deveriam ser de vários tipos, os quais serão detalhados no item seguinte, que aborda os materiais e o método empregados. Observamos em vários trabalhos similares que as notas tanto podem vir reunidas no final da tradução como podem ser colocadas ao longo do texto, sob a forma de notas de rodapé, e optamos pela segunda forma de apresentação.

Se nos restringíssemos ao âmbito específico dos estudos da tradução, o esperado seria que essas notas trouxessem comentários que apresentassem as reflexões do tradutor acerca de suas escolhas ou que abordassem os problemas encontrados, bem como as soluções dadas. No caso do nosso trabalho, no entanto, como nos propusemos a realizar um tipo de tradução que pretende atender não só a um público interessado nas questões de tradução, mas também a um público de profissionais e estudantes de Biologia, julgamos pertinente inserir também outros tipos de notas, tratando do contexto histórico e abordando as questões científicas.

Com relação ao título dado ao trabalho, resolvemos adotar "tradução comentada", por julgá-la mais abrangente, podendo ser entendido como qualquer trabalho de tradução que envolva os comentários, sejam eles apresentados ou não na forma de notas.

Ao longo do desenvolvimento do projeto, gradativamente nos demos conta de que, à medida que cresce a importância de um texto fonte (em termos científicos, filosóficos ou 
literários), mais comentários podem ser acrescidos à tradução. Por isso, o texto-fonte por nós escolhido nos pareceu bastante adequado a esse tipo de trabalho, por se tratar de uma obra de grande importância no cenário científico não só na época de sua publicação, mas também ao longo de toda a história da ciência e com reflexos ainda nos dias de hoje. Julgamos que este seria um material bastante adequado para uma pesquisa no escopo de uma tradução comentada, pois com isso poderíamos torná-lo acessível aos leitores brasileiros de diferentes áreas e de diferentes níveis de conhecimento científico.

Um de nossos objetivos foi, portanto, o de poder divulgar o saber científico que a obra original encerra para outras esferas que não apenas da área da Biologia ou da Tradução, podendo ser aproveitado por estudiosos da Filosofia, da Epistemologia, da História da Ciência e também pelo público em geral, interessado na história do conhecimento humano.

Nos itens a seguir, exporemos a maneira como foi realizado este trabalho, apresentando, em seguida, o resultado final da tradução bilíngue, com os diferentes tipos de notas de rodapé.

\subsection{Materiais e Método}

\subsubsection{Materiais}

Os materiais utilizados na pesquisa foram, do ponto de vista da pesquisa histórica e terminológica, os textos, livros e artigos publicados por Claude Bernard no período de 1843 a 1880, disponíveis em bibliotecas e consultados tanto na França quanto no Brasil: Université Lyon 1- Claude Bernard, Université Lyon 2- Lumière, Faculdade de Filosofia, Letras e Ciências Humanas da Universidade de São Paulo, Instituto de Biociências da Universidade de São Paulo, Instituto de Ciências Biomédicas da Universidade de São Paulo USP, na maioria em suas coleções de obras raras. Uma parte desse material conta com edições publicadas recentemente em francês, como Introduction à l'étude de la médecine expérimentale, que nos serve de corpus (BERNARD, 1865,2008 ) ou o Cahier de notes (BERNARD, 1965). Consultamos também obras de autores que se dedicaram ao estudo da obra de Claude Bernard e/ou da sua importância para a História da Biologia (GRMEK, 1997; DUTRA, 2003; HADDAD, 2012; ROSTAND, 1955, entre outros). 
A maior parte, senão a totalidade de publicações desse autor, corresponde a obras de domínio público, uma vez que já foram publicados há mais de setenta anos. Sendo assim, pudemos ter acesso a elas diretamente em versões digitalizadas (e-books) que podem ser baixadas em páginas como:

http://www.claude-bernard.co.uk/page15.htm https://searchise.com/author/MWVieHI4YQ /Claude-Bernard http://www.ebooksgratuits.com/pdf/bernard introduction etude medecine experimentale.pdf https://archive.org/details/leonssurlesp02bern

Ainda desse mesmo ponto de vista, citamos os textos diretamente ligados às bases teóricas da tradução (BAKER, 2011; BASNETT, 2003; BERMAN, 2011; ESTEVES, 2014; KRIEGER, 2006; VENUTI, 2002, entre outros), além de dicionários (FERREIRA, 1986 e dicionários on line http://www.cnrtl.fr/lexicographie/ ; http://www.sinonimos.com.br/), glossários e publicações de Biologia (REY, 1999; CURTIS e BARNES, 1989, entre outros), ramo da ciência ao qual pertence a obra que é objeto deste trabalho.

Do ponto de vista técnico, scanner (para digitalizar os livros de coleções raras, que não puderam ser emprestados), os softwares de produção de texto e o conhecimento humano de especialistas que foram consultados (citados na Introdução deste trabalho (p. 17), inclusive o da autora deste trabalho, que possui graduação e mestrado em Biologia e graduação em Letras/Francês.

\subsubsection{Método}

O projeto de tradução que foi colocado em prática para a elaboração deste trabalho pautouse na opção de realizar uma tradução que mantivesse as estruturas da época em que o texto foi escrito. Desse modo, o aspecto histórico foi privilegiado e, nesse sentido, as informações biológicas foram atualizadas conforme seu interesse dentro do projeto, sob a forma de notas, todas as vezes em que se julgou necessário esclarecer alguma informação científica que pudesse, de alguma forma, comprometer o entendimento do texto por se tratar de linguagem científica do século XIX. 
A realização do trabalho foi dividida em várias etapas. A primeira etapa se estendeu ao longo de boa parte do projeto, desde o início até praticamente o seu final e consistiu no levantamento bibliográfico, não apenas do total da obra de Claude Bernard, mas também de obras que tratam de sua importância principalmente nas áreas da Biologia e especificamente da Fisiologia, sem deixar de lado, no entanto, as obras que também analisam sua importância nos campos da Filosofia, da História da Ciência ou de tudo aquilo que pudesse trazer uma fundamentação teórica para os procedimentos de nossa proposta de tradução comentada.

A segunda etapa consistiu na elaboração dos procedimentos de tradução que seriam utilizados, discutidos com a orientadora com base no que vinha sendo levantado nas pesquisas bibliográficas, bem como a escolha do material que seria escolhido para a realização do trabalho. As discussões, nessa fase, levaram também em conta a opinião de especialistas das áreas de Fisiologia, de Filosofia e de História da Ciência.

Em um primeiro encontro do grupo (Christine Janczur, profa. Dra. Adriana Zavaglia, Prof. Dr. Hamilton Haddad Jr. e Profa. Dra. Maria Elice Brzezinski Prestes), foram levantados alguns títulos considerados mais adequados ao projeto, até que foi definido, pelas considerações dos especialistas, como já relatado na Introdução deste trabalho, qual livro seria traduzido, em parte ou integralmente: Introduction à l'étude de la médecine expérimental (1865).

As discussões ocorreram ainda em outras ocasiões, em especial com o professor Haddad, a fim de que pudéssemos trabalhar em conjunto a linguagem a ser utilizada (já que se tratava de obra escrita no século XIX), além de definir qual seria o público alvo do trabalho final, como e onde seriam encontrados os equivalentes dos termos científicos específicos e como o resultado final poderia trazer interesse nas áreas de Fisiologia e História da Ciência, além daquele central voltado aos estudos da tradução.

Quanto à linguagem, decidimos mantê-la o mais próximo possível da linguagem utilizada pelo autor no século XIX, privilegiando o aspecto histórico. Quanto ao público-alvo, decidimos destinar nosso texto a pessoas ligadas à área de Biologia e Fisiologia, principalmente estudantes de Biologia e de História da Biologia, abrangendo também profissionais da área, como professores e pesquisadores, além de filósofos interessados nos aspectos epistemológicos da obra e de 
estudiosos da tradução. Em relação aos equivalentes dos termos científicos, optamos por consultar obras contemporâneas ao nosso texto-fonte nas duas línguas envolvidas, bem como obras específicas de Fisiologia atuais, tanto em francês quanto em português.

A terceira etapa consistiu na tradução da obra escolhida, o que ocupou a maior parte do desenvolvimento desta pesquisa. Como ainda não há, nos Estudos da Tradução, uma metodologia para realizar uma tradução comentada, criamos a nossa. Inicialmente, um livro disponível em arquivo PDF, de domínio público, foi integralmente copiado para um arquivo Word. Nesse arquivo, foram criadas três colunas: na primeira, foi colocado o texto original em francês; na segunda, foi deixado o espaço onde viria a ser construído o texto em português; e na terceira, o espaço para que fossem acrescentados comentários e observações levantadas durante o processo de tradução e também as nossas notas.

Os parágrafos foram separados por linhas, em uma tabela, ficando em células isoladas, um em cada célula, como será mostrado abaixo. Lado a lado, na mesma linha dessa tabela, foram colocados os parágrafos correspondentes do texto traduzido, para garantir que os mesmos não se desencontrassem por conta de eventuais quantidades de linhas diferentes, já que nem sempre os dois textos (o original e o traduzido) apresentam o mesmo número de linhas e/ou de palavras. Essa medida foi tomada para facilitar a comparação dos parágrafos em francês e em português, caracterizando uma tradução bilíngue.

Nos quadros a seguir, mostramos exemplos de como se desenvolveu o processo de tradução, apresentando trechos: em sua configuração inicial (em três colunas), no decorrer do processo (confecção das notas) e na sua versão final (duas colunas, com notas de rodapé). Mostramos também a maneira como lidamos com as notas originais do autor, em relação às notas produzidas no decorrer do processo tradutório, para que não fossem confundidas na apresentação final da tradução. 


\begin{tabular}{|c|c|c|}
\hline $\begin{array}{l}\text { Claude Bernard } \\
\text { Introduction à l'étude de la } \\
\text { médecine expérimentale } \\
\text { (Première Partie) }\end{array}$ & $\begin{array}{l}\text { Claude Bernard } \\
\text { Introdução ao estudo da } \\
\text { medicina experimental } \\
\text { (Primeira Parte) }\end{array}$ & \\
\hline $\begin{array}{l}\text { Introduction } \\
\text { Par Claude Bernard }\end{array}$ & $\begin{array}{l}\text { Introdução } \\
\text { Claude Bernard }\end{array}$ & \\
\hline $\begin{array}{l}\text { Conserver la santé et guérir } \\
\text { les maladies : tel est le } \\
\text { problème que la médecine a } \\
\text { posé dès son origine et dont } \\
\text { elle poursuit encore la } \\
\text { solution scientifique. L'état } \\
\text { actuel de la pratique } \\
\text { médicale donne à présumer } \\
\text { que cette solution se fera } \\
\text { encore longtemps chercher. }\end{array}$ & $\begin{array}{l}\text { Conservar a saúde e curar as } \\
\text { doenças: tal é o problema } \\
\text { que a medicina propôs } \\
\text { desde sua origem e para o } \\
\text { qual ainda busca uma } \\
\text { solução científica. O estado } \\
\text { atual da prática médica leva } \\
\text { a presumir que essa solução } \\
\text { ainda será procurada por } \\
\text { muito tempo. }\end{array}$ & $\begin{array}{l}\text { Inserir aqui uma nota de } \\
\text { tradução explicando como } \\
\text { era o estado da prática } \\
\text { médica na época em que } \\
\text { foi escrito o texto. }\end{array}$ \\
\hline
\end{tabular}

Quadro 1- Exemplo de organização do trabalho no início da tradução: texto fonte (primeira coluna), texto traduzido (segunda coluna) e comentários (terceira coluna).

Nesta primeira etapa do trabalho, mostrada no quadro 1, à medida em que a tradução era realizada, os trechos que, a nosso ver, apresentavam potencial para o desenvolvimento de notas eram evidenciados para serem desenvolvidos em etapa posterior. Na última coluna da direita, eram feitos comentários para indicar, de forma ainda bastante rudimentar, as notas que poderiam ser desenvolvidas posteriormente. Além disso, eram colocadas observações a respeito de padronizações que deveriam ser feitas ao longo de todo o processo da tradução, como a manutenção dos grifos do autor ou ainda, dependendo do caso, lembretes sobre as maneiras como trataríamos as citações em outras línguas (como o latim) e/ou todo e qualquer tipo de informação que pudesse despertar a nossa atenção em relação à apresentação final da tradução. A etapa seguinte deste processo está apresentada na tabela seguinte. 


\begin{tabular}{|l|l|}
\hline $\begin{array}{l}\text { Claude Bernard } \\
\text { Introduction à l'étude de la } \\
\text { Paris : Garnier-Flammarion, [1865]1966, 318 } \\
\text { pp. (Première Partie) }\end{array}$ & $\begin{array}{l}\text { Claude Bernard } \\
\text { Introdução ao estudo da medicina } \\
\text { experimental Tradução para o português do } \\
\text { Brasil por Christine Janczur } \\
\text { (Primeira Parte) }\end{array}$ \\
\hline $\begin{array}{l}\text { Introduction } \\
\text { Par Claude Bernard }\end{array}$ & $\begin{array}{l}\text { Introdução } \\
\text { Claude Bernard }\end{array}$ \\
\hline $\begin{array}{l}\text { Conserver la santé et guérir les maladies : tel } \\
\text { est le problème que la médecine a posé dès } \\
\text { son origine et dont elle poursuit encore la } \\
\text { solution scientifique. L'état actuel de la } \\
\text { pratique médicale donne à présumer que } \\
\text { cette solution se fera encore longtemps } \\
\text { chercher. }\end{array}$ & $\begin{array}{l}\text { Conservar a saúde e curar as doenças: tal é o } \\
\text { problema que a medicina propôs desde sua } \\
\text { persegue. O estado atual da prática médica } \\
\text { [Nota] leva a presumir que essa solução } \\
\text { ainda será buscada por muito tempo. }\end{array}$ \\
\hline
\end{tabular}

N.T. Estado atual da prática médica: conjunto das práticas executadas até o ano de 1865 por rotina, sem fundamento científico. O estado da prática médica em 1865, ao qual Claude Bernard se refere, certamente era muito diferente do de hoje. No que diz respeito ao conhecimento do que causava as doenças, seu diagnóstico e tratamento, existiam ainda enormes desafios. Muitas dessas explicações se baseariam, posteriormente, nos trabalhos de Claude Bernard, que, a partir de suas descobertas, estabeleceu um verdadeiro ponto de virada na compreensão dos fenômenos fisiológicos que regulam o corpo humano e na maneira de tratar as doenças. Essa era uma época em que, como mencionado no capítulo 1, práticas como a sangria eram executadas apenas por rotina, sem qualquer fundamento científico. O papel dos micro-organismos como causadores de doenças ainda não era bem determinado. Louis Pasteur, contemporâneo de Claude Bernard, fez suas descobertas a esse respeito em 1864 (CURTIS e BARNES,1989, p.86-87); no momento em que Claude Bernard escreveu sua obra, essas ideias ainda não tinham sido aplicadas à prática médica. Vacinas como a Salk ou a Sabin, contra a poliomielite, só apareceram nos anos 1950 (CURTIS e BARNES,1989, p.448-449). O interior do organismo e os processos cirúrgicos ainda não tinham sido explorados e constituíam uma área da Medicina ainda bastante inexplorada, assim como a Fisiologia e a Patologia. O estado da medicina nesse período como um todo pode ser visto com mais detalhes em VIEIRA, 2012, pp.582-621.

Quadro 2- Exemplo de organização do trabalho durante o desenvolvimento do processo de tradução, com o texto em duas colunas, sendo: texto fonte (primeira coluna), texto traduzido (segunda coluna) e notas de rodapé.

No quadro acima, em que mostramos um exemplo do procedimento ao longo do desenvolvimento do trabalho, podemos verificar que a ideia originalmente levantada em forma de comentário foi transformada numa nota cujo objetivo, neste caso, era o de colocar o leitor no contexto do estado da ciência do século XIX, apresentando alguns fatos, de forma bastante breve, que contextualizariam as palavras de Claude Bernard, distantes da realidade da ciência médica do século XXI. 
Ao final do processo de tradução, todas as notas foram revisadas e analisadas em relação à sua pertinência, já diante do resultado final do texto traduzido. O que ocorreu em vários casos foi que algumas notas que tinham sido levantadas inicialmente acabaram se mostrando desnecessárias ou redundantes, razão pela qual foram removidas em uma etapa final. A nota acima exemplificada se encaixa nesse exemplo e a tabela a seguir mostra o resultado final desse trecho.

\begin{tabular}{|l|l|}
\hline $\begin{array}{l}\text { Claude Bernard } \\
\text { Introduction à l'étude de la } \\
\text { médecine expérimentale } \\
\text { Paris: Garnier-Flammarion, [1865]1966, 318 } \\
\text { pp. (Première Partie) }\end{array}$ & $\begin{array}{l}\text { Claude Bernard } \\
\text { Introdução ao estudo da medicina } \\
\text { experimental Tradução para o português do } \\
\text { Brasil por Christine Janczur } \\
\text { (Primeira Parte) }\end{array}$ \\
\hline $\begin{array}{l}\text { Introduction } \\
\text { Par Claude Bernard }\end{array}$ & $\begin{array}{l}\text { Introdução } \\
\text { Claude Bernard }\end{array}$ \\
\hline $\begin{array}{l}\text { Conserver la santé et guérir les maladies : tel } \\
\text { est le problème que la médecine a posé dès } \\
\text { son origine et dont elle poursuit encore la } \\
\text { solution scientifique. L'état actuel de la } \\
\text { pratique médicale donne à présumer que } \\
\text { cette solution se fera encore longtemps } \\
\text { chercher. }\end{array}$ & $\begin{array}{l}\text { Consaúde e curar as doenças: tal é o } \\
\text { problema que a medicina propôs desde sua } \\
\text { persegue. O estado atual da prática médica } \\
\text { leva a presumir que essa solução ainda será } \\
\text { buscada por muito tempo. }\end{array}$ \\
\hline
\end{tabular}

Quadro 3- Exemplo de organização do trabalho na sua forma final do processo de tradução, com o texto em duas colunas, sendo: texto fonte (primeira coluna), texto traduzido (segunda coluna) e notas de rodapé, quando consideradas pertinentes.

A exclusão dessa nota na versão final foi decidida por nos termos dado conta de que qualquer explicação resumida e simplista a respeito do estado da ciência do século XIX pareceria demasiadamente óbvia ao leitor alvo desse tipo de texto. Se pretendêssemos oferecer dados que pudessem ir além do que julgávamos redundante, a nota teria que ser demasiadamente longa, o que fugiria aos objetivos do presente trabalho. $O$ assunto em questão seria tão vasto, que mereceria um estudo à parte. Algumas outras notas foram removidas pelo mesmo motivo, isto é, por nos parecerem redundantes quando pudemos ter uma visão geral do trabalho já concluído. 
Em outros casos, no entanto, as notas se mostraram produtivas e pertinentes, tendo sido conservadas. Os quadros 4 e 5, a seguir mostram o exemplo de uma nota, respectivamente, quando ela foi apontada como promissora através de comentário e quando a nota foi desenvolvida (forma que foi mantida na apresentação final).

\begin{tabular}{|c|c|c|}
\hline $\begin{array}{l}\text { Il est ainsi évident pour tout } \\
\text { esprit non prévenu que la } \\
\text { médecine se dirige vers sa } \\
\text { voie scientifique définitive. } \\
\text { Par la seule marche naturelle } \\
\text { de son évolution, elle } \\
\text { abandonne peu à peu la } \\
\text { région des systèmes pour } \\
\text { revêtir de plus en plus la } \\
\text { forme analytique, et rentrer } \\
\text { ainsi graduellement dans la } \\
\text { méthode d'investigation } \\
\text { commune aux sciences } \\
\text { expérimentales. }\end{array}$ & $\begin{array}{l}\text { É, assim, evidente para todo } \\
\text { espírito não prevenido que a } \\
\text { medicina se dirige rumo a sua } \\
\text { via científica definitiva. } \\
\text { Somente pela marcha natural } \\
\text { de sua evolução, ela } \\
\text { abandona pouco a pouco a } \\
\text { região dos sistemas para } \\
\text { assumir cada vez mais a } \\
\text { forma analítica e assim } \\
\text { entrar, gradualmente, no } \\
\text { método de investigação } \\
\text { comum às ciências } \\
\text { experimentais. }\end{array}$ & $\begin{array}{l}\text { Esprit/Espírito: ele usa a palavra } \\
\text { para falar do pensamento, da } \\
\text { mente. Em francês, hoje, } \\
\text { encontramos como sinônimos: } \\
\text { inteligência, gênio, razão, alma. } \\
\text { Nas entradas do dicionário, } \\
\text { aparecem primeiro e prevalecem as } \\
\text { conotações ligadas à alma ou a um } \\
\text { corpo etéreo. }\end{array}$ \\
\hline
\end{tabular}

Quadro 4- Exemplo de organização do trabalho no início da tradução, para uma nota que foi conservada até o final, contendo: texto fonte (primeira coluna), texto traduzido (segunda coluna) e comentários (terceira coluna). 


\begin{tabular}{|l|l|}
\hline II est ainsi évident pour tout esprit non & Assim, é evidente para todo espírito [Nota] \\
prévenu que la médecine se dirige vers sa & $\begin{array}{l}\text { sem preconceitos que a medicina ruma em } \\
\text { voie scientifique définitive. Par la seule } \\
\text { direção à sua via científica definitiva. }\end{array}$ \\
marche naturelle de son évolution, elle & Simplesmente pelo curso natural de sua \\
abandonne peuà peu la région des systèmes & evolução, ela abandona pouco a pouco a \\
pour revêtir de plus en plus la forme & região dos sistemas para assumir cada vez \\
analytique, et rentrer ainsi graduellement & mais a forma analítica e assim entrar, \\
dans la méthode d'investigation commune & gradualmente, no método de investigação \\
aux sciences expérimentales. & comum às ciências experimentais. \\
\hline
\end{tabular}

N.T esprit s.m. espírito, pensamento, mente.

O autor utiliza a palavra no sentido de pensamento; a acepção que seria hoje a mais adequada ao contexto seria mente. No entanto, a fim de retratar o vocabulário da época e de acordo com a nossa proposta de tradução, mantivemos a palavra que, em português, corresponde mais diretamente ao termo utilizado no século XIX.

Quadro 5- Exemplo de organização do trabalho durante o desenvolvimento do processo de tradução (e, neste caso, também na sua forma final), com o texto em duas colunas, sendo: texto fonte (primeira coluna), texto traduzido (segunda coluna) e notas de rodapé.

Uma outra questão com a qual tivemos que lidar, no que diz respeito à apresentação final da tradução foi a das notas do próprio autor, que ao aparecerem no rodapé do texto, não poderiam ser confundidas com as notas que foram propostas pela tradutora.

\begin{tabular}{|c|c|c|}
\hline $\begin{array}{l}\text { Il en sera de même d'une infinité } \\
\text { de lésions pathologiques qui sont } \\
\text { de véritables expériences dont le } \\
\text { médecin et le physiologiste tirent } \\
\text { profit, sans que cependant il y ait } \\
\text { de leur part aucune } \\
\text { préméditation pour provoquer } \\
\text { ces lésions qui sont le fait de la } \\
\text { maladie. Je signale dès à présent } \\
\text { cette idée parce qu'elle nous sera } \\
\text { utile plus tard pour prouver que la } \\
\text { médecine possède de véritables } \\
\text { expériences, bien que ces } \\
\text { dernières soient spontanées et } \\
\text { non provoquées par le médecin }{ }^{1} \text {. }\end{array}$ & $\begin{array}{l}\text { Será esse o caso de uma infinidade } \\
\text { de lesões patológicas que são } \\
\text { verdadeiras experiências das } \\
\text { quais o médico e o fisiologista } \\
\text { tiram proveito, sem que, no } \\
\text { entanto, haja de sua parte } \\
\text { qualquer premeditação para } \\
\text { produzir essas lesões que são a } \\
\text { causa da doença. Assinalo desde } \\
\text { já essa ideia, porque ela nos será } \\
\text { útil mais tarde para provar que a } \\
\text { medicina possui verdadeiras } \\
\text { experiências, ainda que sejam } \\
\text { espontâneas e não provocadas } \\
\text { pelo médico. [Nota 4] }\end{array}$ & $\begin{array}{l}\text { Provoquer: provocar, produzir, } \\
\text { causar.... inserir na forma de } \\
\text { glossário e padronizar a forma } \\
\text { escolhida. }\end{array}$ \\
\hline 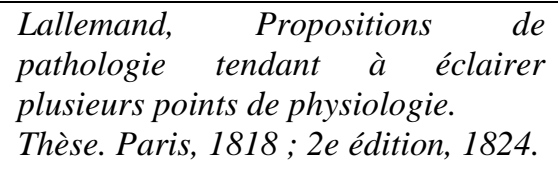 & $\begin{array}{l}\text { [Nota 4] Lallemand, Propositions de } \\
\text { pathologie tendant à éclairer } \\
\text { plusieurs points de physiologie. } \\
\text { Tese. Paris, } 1818 ; 2 \text { a edição, } 1824 \text {. }\end{array}$ & \\
\hline
\end{tabular}

Quadro 6- Exemplo de organização do trabalho no início da tradução, para uma nota do autor, contendo: texto fonte (primeira coluna), texto traduzido (segunda coluna) e comentários (terceira coluna). 
No exemplo mostrado no quadro acima, a ideia original era a de manter as notas originais do autor no corpo do texto, de forma a diferenciá-las das notas de tradução, que viriam no pé da página. Posteriormente, ao fazer a passagem do texto para a forma de duas colunas e ao organizar a forma final de apresentação, decidimos que seria mais interessante colocar todas as notas (do autor e da tradutora) sob a forma de notas de rodapé. Todas as notas produzidas durante o processo de tradução foram então identificadas pela sigla N.T., enquanto as notas originais do autor do texto em francês foram transferidas para o rodapé, da forma como aparecem no texto original. O resultado final é mostrado na tabela a seguir.

\begin{tabular}{|c|c|}
\hline $\begin{array}{l}\text { Il en sera de même d'une infinité de lésions } \\
\text { pathologiques qui sont de véritables } \\
\text { expériences dont le médecin et le physiologiste } \\
\text { tirent profit, sans que cependant il y ait de leur } \\
\text { part aucune préméditation pour provoquer ces } \\
\text { lésions qui sont le fait de la maladie. Je signale } \\
\text { dès à présent cette idée parce qu'elle nous sera } \\
\text { utile plus tard pour prouver que la médecine } \\
\text { possède de véritables expériences, bien que ces } \\
\text { dernières soient spontanées et non provoquées } \\
\text { par le médecin. }\end{array}$ & 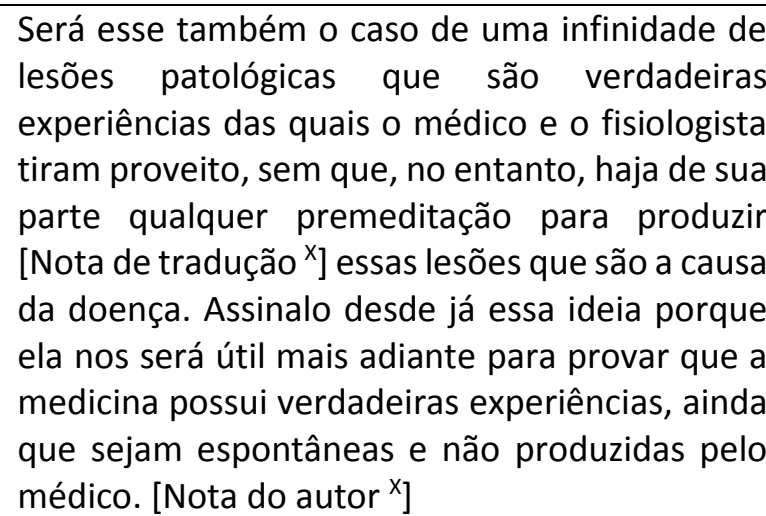 \\
\hline
\end{tabular}

${ }^{\mathrm{X}}$ N.T. provoquer v. $t$. provocar, produzir, suscitar, ocasionar, determinar, causar.

O verbo provoquer foi traduzido por produzir, termo em português que se mostrou o mais adequado a todos os contextos em que ele ocorreu. Provoquer l'expérience, portanto, foi traduzido para o português por produzir a experiência. Os outros contextos em que aparece esse verbo são: produzir fatos, produzir observações, produzir lesões.

${ }^{x}$ LALLEMAND, Propositions de pathologie tendant à éclairer plusieurs points de physiologie. Thèse. Paris, 1818; 2e édition, 1824.

Quadro 7- Exemplo de organização do trabalho durante o desenvolvimento do processo de tradução (e, neste caso, também na sua forma final), com o texto em duas colunas, sendo: texto fonte (primeira coluna), texto traduzido (segunda coluna) e notas de rodapé originais do autor, identificadas apenas pelo seu número e as da tradutora, identificadas pelo seu número e precedidas da sigla N.T. 
É importante observar que nos exemplos acima apresentamos o processo que realizamos, desde um esboço do que viria a ser a tradução final, bem diferente da forma que ela assumiu após o término do trabalho prático, até a versão final. As notas iam sendo inicialmente inseridas como observações, para serem depois desenvolvidas, trabalhadas ou eventualmente excluídas, até que todo o texto traduzido, com cerca de cem páginas, pudesse adquirir sua forma final.

Quando as notas começaram a ser trabalhadas, nos demos conta de que elas tinham diferentes características e que elas poderiam ser consideradas como notas de diferentes tipos, a saber: as históricas, compreendendo fatos que refletem um dado momento da História da Biologia (como os dados sobre a proposição do determinismo científico, sobre o papel histórico de cientistas citados ou sobre eventos que foram importantes para o desenvolvimento da ciência); as explicativas, que são um elemento facilitador para o leitor não familiarizado com termos de Biologia (como "rochedo": estrutura do osso temporal, "hipocôndrio": parte lateral do abdome etc.); as atualizadoras, que atualizam termos (como "seres elevados"/"seres complexos"; "experiência"/"experimento" etc.) e as de tradução propriamente dita, mostrando as escolhas e opções adotadas (colocações, como "un fait que s'offre" traduzido para "um fato que se apresenta" ou "garder la précaution" por "ter a precaução").

Tais notas foram pensadas para satisfazer o possível público leitor do trabalho, evidentemente diferente daquele da obra original, do século XIX. Julgamos pertinente manter diferentes tipos de notas para atender a públicos diferentes, uma vez que se trata de um trabalho que aborda aspectos de diferentes áreas do conhecimento. Assim, embora uma explicação do que é uma escara possa parecer desnecessária para o leitor de Biologia, ela pode ser útil ao leitor leigo nessa área. Da mesma forma, as notas relativas a aspectos da tradução podem ser necessárias para o entendimento do texto por parte de leitores voltados à área científica e não familiarizados com esses aspectos.

Essa versão inicial da tradução foi lida pela orientadora, que priorizou em sua correção os aspectos linguísticos e da tradução propriamente dita, tendo levantado outras possíveis notas, além daquelas inicialmente levantadas por mim. Feito isto, o texto em português foi lido para 
que outras possíveis notas correspondentes especificamente ao contexto biológico pudessem ser levantadas.

Todo o procedimento citado acima foi realizado, como já mostrado nos quadros, com o texto inicialmente organizado nas três colunas, com a finalidade de facilitar o trabalho de tradução e de facilitar a colocação das notas ao lado do texto correspondente. Por uma questão prática, o texto foi trabalhado com a página na orientação "paisagem".

Terminada a tradução, o texto geral foi reorganizado, desta vez em duas colunas com os textos original e traduzido, na orientação "retrato", tendo sido as notas (que se encontravam originalmente em uma terceira coluna que foi eliminada), juntamente com as notas originais do autor, já em sua versão final, transferidas para o pé da página, na forma de notas de rodapé. Como algumas dessas notas poderiam servir a mais de um dos tipos, optamos por não fazer a distinção entre elas, mantendo apenas a sigla N.T. em todos os casos. Essa é a configuração que pode ser vista no próximo item deste capítulo, no qual apresentamos o resultado final da tradução.

Pelo andamento do projeto, que se mostrou bem mais trabalhoso do que se supunha inicialmente, tivemos que decidir pela utilização da introdução do livro e da sua primeira parte para a tradução, correspondendo a 94 páginas de um total de 318. A O livro é composto, em sua totalidade, pela Introdução e mais três partes: Do raciocínio experimental, A experimentação nos seres vivos, Aplicações do método experimental no estudo dos fenômenos da vida. Ficamos assim com a Introdução e com a parte 1, intitulada Do raciocínio experimental. A opção de tradução que escolhemos foi estrangeirizante, privilegiando os aspectos históricos, tentando levar o leitor à época em que foi escrito o texto. Com relação à terminologia, procuramos retratar a linguagem do século XIX, evidenciando o contexto científico em que a obra se insere. No próximo item, mostramos o resultado da nossa proposta de tradução. 


\subsection{Tradução da Introdução do livro e da Primeira Parte: Do raciocínio experimental.}

\begin{tabular}{|c|c|}
\hline $\begin{array}{l}\text { Claude Bernard } \\
\text { Introduction à l'étude de la } \\
\text { médecine expérimentale } \\
\text { Paris : Garnier-Flammarion, [1865]1966, } 318 \\
\text { pp (Introduction et Première Partie) }\end{array}$ & $\begin{array}{l}\text { Christine Janczur } \\
\text { Introdução ao estudo da medicina } \\
\text { experimental }\end{array}$ \\
\hline $\begin{array}{l}\text { on } \\
\text { Bernard }\end{array}$ & $\begin{array}{l}\text { Introdução } \\
\text { Claude Bernard }\end{array}$ \\
\hline $\begin{array}{l}\text { Conserver la santé et guérir les maladies : tel } \\
\text { est le problème que la médecine a posé dès } \\
\text { son origine et dont elle poursuit encore la } \\
\text { solution scientifique. L'état actuel de la } \\
\text { pratique médicale donne à présumer que } \\
\text { cette solution se fera encore longtemps } \\
\text { chercher. Cependant, dans sa marche à } \\
\text { travers les siècles, la médecine, } \\
\text { constamment forcée d'agir, a tenté } \\
\text { d'innombrables essais dans le domaine de } \\
\text { l'empirisme et en a tiré d'utiles } \\
\text { enseignements. Si elle a été sillonnée et } \\
\text { bouleversée par des systèmes de toute } \\
\text { espèce que leur fragilité a fait } \\
\text { successivement disparaître, elle n'en a pas } \\
\text { moins exécuté des recherches, acquis des } \\
\text { notions et entassé des matériaux précieux, } \\
\text { qui auront plus tard leur place et leur } \\
\text { signification dans la médecine scientifique. } \\
\text { De notre temps, grâce aux développements } \\
\text { considérables et aux secours puissants des } \\
\text { sciences physico-chimiques, l'étude des } \\
\text { phénomènes de la vie, soit à l'état normal, }\end{array}$ & $\begin{array}{l}\text { Conservar a saúde e curar as doenças: tal é o } \\
\text { problema que a medicina propôs desde sua } \\
\text { origem e cuja solução científica ela ainda } \\
\text { persegue }{ }^{41} \text {. O estado atual da prática médica } \\
\text { leva a presumir que essa solução ainda será } \\
\text { buscada por muito tempo. No entanto, em } \\
\text { sua marcha através dos séculos, a medicina, } \\
\text { constantemente forçada a agir, fez } \\
\text { incontáveis tentativas no domínio do } \\
\text { empirismo e dele tirou ensinamentos úteis. } \\
\text { Se ela foi revolvida e abalada por toda sorte } \\
\text { de sistemas que, por sua fragilidade, foram } \\
\text { sucessivamente desaparecendo, ela, mesmo } \\
\text { assim, não deixou de realizar pesquisas, } \\
\text { adquirir noções e acumular materiais } \\
\text { preciosos, que terão mais tarde seu lugar e } \\
\text { sua significação na medicina científica. Nos } \\
\text { dias de hoje, graças aos desenvolvimentos } \\
\text { consideráveis e aos poderosos suportes das } \\
\text { ciências físico-químicas, o estudo dos } \\
\text { fenômenos da vida, seja no estado normal, } \\
\text { seja no estado patológico, obteve }\end{array}$ \\
\hline
\end{tabular}

\footnotetext{
${ }^{41}$ Ver. Cours de pathologie expérimentale. - Medical Times, 1859-1860. - Leçon d'ouverture du cours de médecine du Collège de France : sur la médecine expérimentale. - Gazette médicale. Paris, Gazette médicale. Paris, 15 avril 1864. - Revue des cours scientifiques. Paris, 31 décembre 1864.
} 


\begin{tabular}{|c|c|}
\hline $\begin{array}{l}\text { soit à l'état pathologique, a accompli des } \\
\text { progrès surprenants qui chaque jour se } \\
\text { multiplient davantage. }\end{array}$ & $\begin{array}{l}\text { progressos surpreendentes que se } \\
\text { multiplicam mais e mais a cada dia. }\end{array}$ \\
\hline $\begin{array}{l}\text { Il est ainsi évident pour tout esprit non } \\
\text { prévenu que la médecine se dirige vers sa } \\
\text { voie scientifique définitive. Par la seule } \\
\text { marche naturelle de son évolution, elle } \\
\text { abandonne peuà peula région des systèmes } \\
\text { pour revêtir de plus en plus la forme } \\
\text { analytique, et rentrer ainsi graduellement } \\
\text { dans la méthode d'investigation commune } \\
\text { aux sciences expérimentales. }\end{array}$ & $\begin{array}{l}\text { Assim, é evidente para todo espírito }{ }^{42} \text { sem } \\
\text { preconceitos que a medicina ruma em } \\
\text { direção à sua via científica definitiva. } \\
\text { Simplesmente pelo curso natural de sua } \\
\text { evolução, ela abandona pouco a pouco a } \\
\text { região dos sistemas para assumir cada vez } \\
\text { mais a forma analítica e assim entrar, } \\
\text { gradualmente, no método de investigação } \\
\text { comum às ciências experimentais. }\end{array}$ \\
\hline $\begin{array}{l}\text { Pour embrasser le problème médical dans } \\
\text { son entier, la médecine expérimentale doit } \\
\text { comprendre trois parties fondamentales : la } \\
\text { physiologie, la pathologie et la } \\
\text { thérapeutique. La connaissance des causes } \\
\text { des phénomènes de la vie à l'état normal, } \\
\text { c'est-à-dire la physiologie, nous apprendra à } \\
\text { maintenir les conditions normales de la vie } \\
\text { et à conserver la santé. La connaissance des } \\
\text { maladies et des causes qui les déterminent, } \\
\text { c'est-à-dire la pathologie, nous conduira, } \\
\text { d'un côté, à prévenir le développement de } \\
\text { ces conditions morbides, et de l'autre à en } \\
\text { combattre les effets par des agents } \\
\text { médicamenteux, c'est-à-dire à guérir les } \\
\text { maladies. }\end{array}$ & $\begin{array}{l}\text { Para abranger o problema médico em sua } \\
\text { integralidade, a medicina experimental deve } \\
\text { compreender três partes fundamentais: a } \\
\text { fisiologia, a patologia e a terapêutica. o } \\
\text { conhecimento das causas dos fenômenos da } \\
\text { vida no seu estado normal, isto é, a } \\
\text { fisiologia, nos ensinará a manter as } \\
\text { condições normais da vida e a conservar a } \\
\text { saúde. O conhecimento das doenças e das } \\
\text { causas que as determinam, isto é, a } \\
\text { patologia, nos conduzirá, por um lado, a } \\
\text { prevenir o desenvolvimento das condições } \\
\text { mórbidas e, por outro, a combater seus } \\
\text { efeitos pelos agentes medicamentosos, isto } \\
\text { é, a curar as doenças. }\end{array}$ \\
\hline $\begin{array}{l}\text { Pendant la période empirique de la } \\
\text { médecine, qui sans doute devra se } \\
\text { prolonger encore longtemps, la physiologie, } \\
\text { la pathologie et la thérapeutique ont pu } \\
\text { marcher séparément, parce que, n'étant } \\
\text { constituées ni les unes ni les autres, elles } \\
\text { n'avaient pas à se donner un mutuel appui } \\
\text { dans la pratique médicale. Mais dans la }\end{array}$ & $\begin{array}{l}\text { Durante o período empírico da medicina, } \\
\text { que, sem dúvida, ainda deverá se prolongar } \\
\text { por muito tempo, a fisiologia, a patologia e a } \\
\text { terapêutica puderam caminhar } \\
\text { separadamente porque, não estando ainda } \\
\text { constituídas, elas não tinham como } \\
\text { oferecer, umas às outras, apoio mútuo na } \\
\text { prática médica. Mas, na concepção da }\end{array}$ \\
\hline
\end{tabular}

\footnotetext{
${ }^{42}$ N.T esprit s.m. espírito, pensamento, mente.

O autor utiliza a palavra no sentido de pensamento; a acepção que seria hoje a mais adequada ao contexto seria mente. No entanto, a fim de retratar o vocabulário da época e de acordo com a nossa proposta de tradução, mantivemos a palavra que, em português, corresponde mais diretamente ao termo utilizado no século XIX.
} 
conception de la médecine scientifique, il ne saurait en être ainsi ; sa base doit être la physiologie. La science ne s'établissant que par voie de comparaison, la connaissance de l'état pathologique ou anormal ne saurait être obtenue, sans la connaissance de l'état normal, de même que l'action thérapeutique sur l'organisme des agents anormaux ou médicaments, ne saurait être comprise scientifiquement sans l'étude préalable de l'action physiologique des agents normaux qui entretiennent les phénomènes de la vie.

Mais la médecine scientifique ne peut se constituer, ainsi que les autres sciences, que par voie expérimentale, c'est-à-dire par l'application immédiate et rigoureuse du raisonnement aux faits que l'observation et l'expérimentation nous fournissent. La méthode expérimentale, considérée en ellemême, n'est rien autre chose qu'un raisonnement à l'aide duquel nous soumettons méthodiquement nos idées à l'expérience des faits.

Le raisonnement est toujours le même, aussi bien dans les sciences qui étudient les êtres vivants que dans celles qui s'occupent des corps bruts. Mais, dans chaque genre de science, les phénomènes varient et présentent une complexité et des difficultés d'investigation qui leur sont propres. C'est ce qui fait que les principes de l'expérimentation, ainsi que nous le verrons plus tard, sont incomparablement plus difficiles à appliquer à la médecine et aux phénomènes des corps vivants qu'à la physique et aux phénomènes des corps bruts.

Le raisonnement sera toujours juste quand il s'exercera sur des notions exactes et sur des faits précis ; mais il ne pourra conduire qu'à medicina científica, isso não poderia ser assim; sua base deve ser a fisiologia. Pelo fato de a ciência não se estabelecer senão por via de comparação, o conhecimento do estado patológico ou anormal não poderia ser obtido sem o conhecimento do estado normal, da mesma forma que a ação terapêutica dos agentes anormais ou dos medicamentos sobre o organismo não poderia ser compreendida cientificamente sem o estudo prévio da ação fisiológica dos agentes normais que sustentam os fenômenos da vida.

Mas a medicina científica, assim como as outras ciências, só pode se constituir por via experimental, ou seja, pela aplicação imediata e rigorosa do raciocínio aos fatos que a observação e a experimentação nos fornecem. O método experimental, considerado em si mesmo, nada mais é que um raciocínio por meio do qual nós submetemos metodicamente nossas ideias à experiência dos fatos.

O raciocínio é sempre o mesmo, tanto nas ciências que estudam os seres vivos quanto naquelas que se ocupam dos corpos brutos. Mas, em cada tipo de ciência, os fenômenos variam e apresentam uma complexidade e dificuldades de investigação que thes são próprias. Isso é o que faz os princípios da experimentação, como veremos mais tarde, serem incomparavelmente mais difíceis de aplicar à medicina e aos fenômenos dos corpos vivos do que à física e aos fenômenos dos corpos brutos.

O raciocínio será correto sempre que se fundamentar em noções exatas e fatos precisos; mas ele estará fadado ao erro 


\begin{tabular}{|c|c|}
\hline $\begin{array}{l}\text { l'erreur toutes les fois que les notions ou les } \\
\text { faits sur lesquels il s'appuie seront } \\
\text { primitivement entachés d'erreur ou } \\
\text { d'inexactitude. C'est pourquoi } \\
\text { l'expérimentation, ou l'art d'obtenir des } \\
\text { expériences rigoureuses et bien } \\
\text { déterminées, est la base pratique et en } \\
\text { quelque sorte la partie exécutive de la } \\
\text { méthode expérimentale appliquée à la } \\
\text { médecine. Si l'on veut constituer les } \\
\text { sciences biologiques et étudier avec fruit les } \\
\text { phénomènes si complexes qui se passent } \\
\text { chez les êtres vivants, soit à l'état } \\
\text { physiologique, soit à l'état pathologique, il } \\
\text { faut avant tout poser les principes de } \\
\text { l'expérimentation et ensuite les appliquer à } \\
\text { la physiologie, à la pathologie et à la } \\
\text { thérapeutique. L'expérimentation est } \\
\text { incontestablement plus difficile en } \\
\text { médecine que dans aucune autre science ; } \\
\text { mais par cela même, elle ne fut jamais dans } \\
\text { aucune plus nécessaire et plus } \\
\text { indispensable. Plus une science est } \\
\text { complexe, plus il importe, en effet, d'en } \\
\text { établir une bonne critique expérimentale, } \\
\text { afin d'obtenir des faits comparables et } \\
\text { exempts de causes d'erreur. C'est } \\
\text { aujourd'hui, suivant nous, ce qui importe le }\end{array}$ & $\begin{array}{l}\text { todas as vezes em que as noções ou os fatos } \\
\text { sobre os quais se apoia estiverem } \\
\text { primariamente maculados pelo erro ou pela } \\
\text { inexatidão. É por isso que a experimentação } \\
\text { ou a arte de obter experiências } 43 \text { rigorosas e } \\
\text { bem determinadas é a base prática e, de } \\
\text { certa forma, a parte que executa o método } \\
\text { experimental aplicado à medicina. Se se } \\
\text { quiser construir as ciências biológicas e } \\
\text { estudar com proveito os fenômenos tão } \\
\text { complexos que acontecem nos seres vivos, } \\
\text { seja no estado fisiológico, seja no estado } \\
\text { patológico, é preciso, primeiramente, } \\
\text { introduzir os princípios da experimentação } \\
\text { e, em seguida, aplicá-los à fisiologia, à } \\
\text { patologia e à terapêutica. A experimentação } \\
\text { é incontestavelmente mais difícil em } \\
\text { medicina do que em qualquer outra ciência; } \\
\text { e por isso mesmo ela nunca foi em nenhuma } \\
\text { delas tão necessária e indispensável. Quanto } \\
\text { mais complexa é uma ciência, mais importa, } \\
\text { sem dúvida, estabelecer para ela uma boa } \\
\text { crítica experimental, a fim de obter fatos } \\
\text { comparáveis e isentos de fontes de erros. } \\
\text { Em nossa opinião, é isso hoje o que mais } \\
\text { importa para o progresso da medicina. }\end{array}$ \\
\hline $\begin{array}{l}\text { Pour être digne de ce nom, } \\
\text { l'expérimentateur doit être à la fois } \\
\text { théoricien et praticien. S'il doit posséder } \\
\text { d'une manière complète l'art d'instituer les } \\
\text { faits d'expérience, qui sont les matériaux de }\end{array}$ & $\begin{array}{l}\text { Para ser digno desse nome, o } \\
\text { experimentador }{ }^{44} \text { deve ser ao mesmo } \\
\text { tempo teórico e prático. Se ele deve possuir } \\
\text { de maneira plena a arte de instituir os fatos } \\
\text { da experiência, que são o material da }\end{array}$ \\
\hline
\end{tabular}

\footnotetext{
${ }^{43}$ N.T. expérience s.f. experiência, experimento. Hoje distingue-se "experiência" (vivência) e "experimento" (atividade no laboratório). O próprio Claude Bernard alerta mais adiante no seu texto que essa distinção pode ser feita também em língua francesa. No entanto, ele afirma que irá utilizar, em qualquer dos casos, a palavra "experiência", uma vez que essa distinção ainda não estava muito bem estabelecida na época. Para obedecer ao mesmo critério que foi outrora adotado por ele, optamos por traduzir a palavra expérience por experiência, em qualquer das conotações, mesmo sabendo que em certos casos o mais coerente atualmente seria dizer experimento (nos casos em que ele se refere ao procedimento de laboratório).

${ }^{44}$ N.T. O termo mais usual para se referir atualmente à pessoa que realiza experimentos em laboratório é pesquisador.
} 


\begin{tabular}{|c|c|}
\hline $\begin{array}{l}\text { la science, il doit aussi se rendre compte } \\
\text { clairement des principes scientifiques qui } \\
\text { dirigent notre raisonnement au milieu de } \\
\text { l'étude expérimentale si variée des } \\
\text { phénomènes de la nature. Il serait } \\
\text { impossible de séparer ces deux choses : la } \\
\text { tête et la main. Une main habile sans la tête } \\
\text { qui la dirige est un instrument aveugle; la } \\
\text { tête sans la main qui réalise reste } \\
\text { impuissante. }\end{array}$ & $\begin{array}{l}\text { ciência, ele também deve perceber } \\
\text { claramente princípios científicos que } \\
\text { dirigem nosso raciocínio ao ambiente do } \\
\text { estudo experimental tão variado dos } \\
\text { fenômenos da natureza. Seria impossível } \\
\text { separar essas duas coisas: a cabeça e a mão. } \\
\text { Uma mão hábil sem a cabeça que a orienta é } \\
\text { um instrumento cego; a cabeça, sem a mão } \\
\text { que executa, permanece impotente. }\end{array}$ \\
\hline $\begin{array}{l}\text { Les principes de la médecine expérimentale } \\
\text { seront développés dans notre ouvrage au } \\
\text { triple point de vue de la physiologie, de la } \\
\text { pathologie et de la thérapeutique. Mais, } \\
\text { avant d'entrer dans les considérations } \\
\text { générales et dans les descriptions spéciales } \\
\text { des procédés opératoires, propres à } \\
\text { chacune de ces divisions, je crois utile de } \\
\text { donner, dans cette introduction, quelques } \\
\text { développements relatifs à la partie } \\
\text { théorique ou philosophique de la méthode } \\
\text { dont le livre, au fond, ne sera que la partie } \\
\text { pratique. }\end{array}$ & $\begin{array}{l}\text { Os princípios da medicina experimental } \\
\text { serão desenvolvidos em nossa obra sob o } \\
\text { triplo ponto de vista da fisiologia, da } \\
\text { patologia e da terapêutica. Mas, antes de } \\
\text { entrar nas considerações gerais e nas } \\
\text { descrições particulares dos procedimentos } \\
\text { operatórios, próprios de cada uma dessas } \\
\text { divisões, creio ser útil fornecer, nesta } \\
\text { introdução, alguns avanços relativos à parte } \\
\text { teórica ou filosófica do método cujo livro, no } \\
\text { fundo, não será senão a parte prática. }\end{array}$ \\
\hline $\begin{array}{l}\text { Les idées que nous allons exposer ici n'ont } \\
\text { certainement rien de nouveau; la méthode } \\
\text { expérimentale et l'expérimentation sont } \\
\text { depuis longtemps introduites dans les } \\
\text { sciences physico-chimiques qui leur doivent } \\
\text { tout leur éclat. À diverses époques, des } \\
\text { hommes éminents ont traité les questions } \\
\text { de méthode dans les sciences; et de nos } \\
\text { jours, M. Chevreul développe dans tous ses }\end{array}$ & $\begin{array}{l}\text { As ideias que vamos expor aqui certamente } \\
\text { não têm nada de novo; o método } \\
\text { experimental e a experimentação estão } \\
\text { presentes há muito tempo nas ciências } \\
\text { físico-químicas que lhes devem todo o seu } \\
\text { brilho. Em diversas épocas, homens } \\
\text { eminentes trataram as questões do método } \\
\text { nas ciências; e, atualmente, o Sr. }{ }^{45} \\
\text { Chevreul }^{46} \text { desenvolve em todas as suas }\end{array}$ \\
\hline
\end{tabular}

${ }^{45}$ N.T. M., MM.: o Sr., a Sra.

Claude Bernard utiliza essas formas de tratamento ao se referir a cientistas que são contemporâneos a ele e muitas vezes colegas. Faz o mesmo quando cita mulheres, utilizando o tratamento MM. (Madame). Nesta obra: M. Chevreul, M. J. Bertrand, M. de Rémusat, MM. Bidder, MM. Regnault et Reset, M. Collomb, M. Pelouze, MM. Boussingault et Roulin, M. Longet, M. Magendie, M. Henri Sainte-Claire Deville. Para citar cientistas ou filósofos que não são contemporâneos, ele procede de outro modo, sem qualquer forma introdutória, como: Descartes, Pascal, Galeno, Spallanzani, Jenner, entre outros.

${ }^{46}$ N.T. Michel-Eugène Chevreul: químico francês nascido em Angers em 1786, notável por seus estudos sobre as propriedades das gordurase um dos maiores especialistas emcor, de fundamental importância para o desenvolvimento de novas técnicas de pinturas. Também foi responsável pela evolução da indústria do sabão quando, em 1823, formulou as bases teóricas das reações químicas envolvidas na produção de sabão, o que 


\begin{tabular}{|c|c|}
\hline $\begin{array}{l}\text { ouvrages des considérations très } \\
\text { importantes sur la philosophie des sciences } \\
\text { expérimentales. Après cela, nous ne } \\
\text { saurions donc avoir aucune prétention } \\
\text { philosophique. Notre unique but est et a } \\
\text { toujours été de contribuer à faire pénétrer } \\
\text { les principes bien connus de la méthode } \\
\text { expérimentale dans les sciences médicales. } \\
\text { C'est pourquoi nous allons ici résumer ces } \\
\text { principes, en indiquant particulièrement les } \\
\text { précautions qu'il convient de garder dans } \\
\text { leur application, à raison de la complexité } \\
\text { toute spéciale des phénomènes de la vie. } \\
\text { Nous envisagerons ces difficultés d'abord } \\
\text { dans l'emploi du raisonnement } \\
\text { expérimental et ensuite dans la pratique de } \\
\text { l'expérimentation. }\end{array}$ & $\begin{array}{l}\text { obras considerações muito importantes } \\
\text { sobre a filosofia das ciências experimentais. } \\
\text { Isto posto, não poderíamos ter, portanto, } \\
\text { nenhuma pretensão filosófica. Nosso único } \\
\text { objetivo é e sempre foi o de contribuir para } \\
\text { introduzir os princípios bem conhecidos do } \\
\text { método experimental nas ciências médicas. } \\
\text { Por isso, vamos resumir aqui esses } \\
\text { princípios, indicando particularmente as } \\
\text { precauções que convém tomar na sua } \\
\text { aplicação, em razão da complexidade toda } \\
\text { especial dos fenômenos da vida. } \\
\text { Consideraremos }{ }^{47} \text { essas dificuldades } \\
\text { primeiramente no emprego do raciocínio } \\
\text { experimental e em seguida na prática da } \\
\text { experimentação. }\end{array}$ \\
\hline
\end{tabular}

possibilitou a sua produção em escala industrial. O pesquisador também descobriu na carne, em 1832, uma substância que denominou creatina. Diretor da famosa fábrica de tapetes Gobelin, que junto com GayLussac e Vauquelin fizeram de Paris o centro da Química do século XVIII, foi um dos pioneiros a se debruçar sobre a matéria corante natural do lenho do pau-brasil. Diretor do museu de história natural Jardin des Plantes (1864-1979), foi o criador do nome colesterol ao denominar esta substância de colesterine (1815). Publicou vários livros, dentre os quais De la loi du contraste simultané des couleurs (1839). Morreu em Paris em 1889 http://www.dec.ufcg.edu.br/biografias/EugenMic.htm

\footnotetext{
47 N.T. envisager v.t. examinar, considerar, pensar. Colocação: o verbo envisager foi traduzido por considerar, que atende a todos os contextos em que ele ocorre (considerar os fatos, os experimentos, as observações).
} 


\begin{tabular}{|c|c|}
\hline $\begin{array}{l}\text { PREMIERE PARTIE } \\
\text { DU RAISONNEMENT } \\
\text { EXPÉRIMENTAL }\end{array}$ & $\begin{array}{l}\text { PRIMEIRA PARTE } \\
\text { DO RACIOCÍNIO EXPERIMENTAL }\end{array}$ \\
\hline $\begin{array}{l}\text { Chapitre Premier } \\
\text { De l'observation et de } \\
\text { l'expérience }\end{array}$ & $\begin{array}{l}\text { Primeiro capítulo } \\
\text { Da observação e da experiência }\end{array}$ \\
\hline $\begin{array}{l}\text { L'homme ne peut observer les phénomènes } \\
\text { qui l'entourent que dans des limites très } \\
\text { restreintes; le plus grand nombre échappe } \\
\text { naturellement à ses sens, et l'observation } \\
\text { simple ne lui suffit pas. Pour étendre ses } \\
\text { connaissances, il a dû amplifier, à l'aide } \\
\text { d'appareils spéciaux, la puissance de ces } \\
\text { organes, en même temps qu'il s'est armé } \\
\text { d'instruments divers qui lui ont servi à } \\
\text { pénétrer dans l'intérieur des corps pour les } \\
\text { décomposer et en étudier les parties } \\
\text { cachées. Il y a ainsi une gradation nécessaire } \\
\text { à établir entre les divers procédés } \\
\text { d'investigation ou de recherches qui } \\
\text { peuvent être simples ou complexes : les } \\
\text { premiers s'adressent aux objets les plus } \\
\text { faciles à examiner et pour lesquels nos sens } \\
\text { suffisent ; les seconds, à l'aide de moyens }\end{array}$ & $\begin{array}{l}\text { O homem não consegue observar os } \\
\text { fenômenos que o rodeiam senão dentro de } \\
\text { limites bem restritos; a maior parte escapa } \\
\text { naturalmente aos seus sentidos e a simples } \\
\text { observação não lhe basta. Para expandir } \\
\text { seus conhecimentos, o homem precisou } \\
\text { amplificar, com a ajuda de aparelhos } \\
\text { especiais, a potência de seus órgãos }{ }^{48} \text {, ao } \\
\text { mesmo tempo que se muniu de } \\
\text { instrumentos diversos }{ }^{49} \text { que lhe permitiram } \\
\text { penetrar no interior dos corpos a fim de } \\
\text { decompô-los e estudar suas partes } \\
\text { escondidas. Assim, existe uma gradação } \\
\text { necessária a estabelecer entre os diversos } \\
\text { procedimentos de investigação ou de } \\
\text { pesquisa, que podem ser simples ou } \\
\text { complexos: os primeiros se destinam aos } \\
\text { objetos mais fáceis de examinar e para os }\end{array}$ \\
\hline
\end{tabular}

\footnotetext{
${ }^{48}$ N.T. Quando Claude Bernard fala de instrumentos que aumentam a potência de órgãos dos sentidos ele se refere, neste caso particular, ao sentido da visão, cujo poder de observação pôde ser aumentado pelo uso de lentes, que foram usadas com essa finalidade pela primeira vez no século XVII, graças ao holandês van Leeuwenhoek, que em 1677 produziu lentes de excelente qualidade, com as quais foi capaz de observar e descrever enorme quantidade de estruturas vivas. Embora ele seja por isso considerado o inventor do microscópio, muito tempo se passou até que os primeiros microscópios combinando duas lentes para aumentar a capacidade de ampliação fossem produzidos e utilizados na pesquisa científica. À época de Claude Bernard, esses aparelhos ópticos não ofereciam a possibilidade de uma ampliação de qualidade que pudesse ir além de cerca de 100 a 150 vezes. Microscópios ópticos mais potentes, com lentes de qualidade que permitissem imagens claras, métodos mais eficientes de preparação de cortes finos e de boa qualidade, assim como microscópios com outros tipos de lentes (como, por exemplo, os eletrônicos) que permitiriam aumentos muito maiores só entraram em uso maciçamente a partir do século XX. (Curtis e Barnes, 1989, p.237; Campbel, 1966, p.7).

${ }^{49}$ N.T. Neste caso, provavelmente Claude Bernard se refere a instrumentos utilizados em cirurgia que ele descreveu e esquematizou em textos específicos, como, por exemplo, o registro iconográfico realizado juntamente com Charles Huette e publicado em 1854 (BERNARD, C et HUETTE, C. Précis iconographique de médecine opératoire et d'anatomie chirurgicale. Paris: Méquignon-Marvis, 1854, 2 vol.).
} 


\begin{tabular}{|c|c|}
\hline $\begin{array}{l}\text { variés, rendent accessibles à notre } \\
\text { observation des objets ou des phénomènes } \\
\text { qui sans cela nous seraient toujours } \\
\text { demeurés inconnus, parce que dans l'état } \\
\text { naturel ils sont hors de notre portée. } \\
\text { L'investigation, tantôt simple, tantôt armée } \\
\text { et perfectionnée, est donc destinée à nous } \\
\text { faire découvrir et constater les phénomènes } \\
\text { plus ou moins cachés qui nous entourent. }\end{array}$ & $\begin{array}{l}\text { quais nossos sentidos bastam; os outros, } \\
\text { com o auxílio de meios variados, tornam } \\
\text { acessíveis à nossa observação objetos ou } \\
\text { fenômenos que, sem eles, ainda nos seriam } \\
\text { desconhecidos, pois, no seu estado natural, } \\
\text { estão fora do nosso alcance. A investigação, } \\
\text { ora simples, ora aparelhada e aperfeiçoada, } \\
\text { é, portanto, destinada a nos fazer descobrir } \\
\text { e constatar os fenômenos mais ou menos } \\
\text { escondidos que nos rodeiam. }\end{array}$ \\
\hline $\begin{array}{l}\text { Mais l'homme ne se borne pas à voir ; il } \\
\text { pense et veut connaître la signification des } \\
\text { phénomènes dont l'observation lui a révélé } \\
\text { l'existence. Pour cela II raisonne, compare } \\
\text { les faits, les interroge, et, par les réponses } \\
\text { qu'il en tire, les contrôle les uns par les } \\
\text { autres. C'est ce genre de contrôle, au moyen } \\
\text { du raisonnement et des faits, qui constitue, } \\
\text { à proprement parler, l'expérience, et c'est le } \\
\text { seul procédé que nous ayons pour nous } \\
\text { instruire sur la nature des choses qui sont en } \\
\text { dehors de nous. }\end{array}$ & $\begin{array}{l}\text { Mas o homem não se limita a ver; ele pensa } \\
\text { e quer conhecer o significado dos } \\
\text { fenômenos cuja observação revelou-lhe a } \\
\text { existência. Para isso ele raciocina, compara } \\
\text { os fatos, os interroga e, pelas respostas que } \\
\text { obtém a partir disso, os controla uns pelos } \\
\text { outros. É esse tipo de controle, por meio do } \\
\text { raciocínio e dos fatos, que constitui, } \\
\text { propriamente falando, a experiência e é esse } \\
\text { o único procedimento que temos para } \\
\text { aprender sobre a natureza das coisas que } \\
\text { estão fora de nós. }\end{array}$ \\
\hline $\begin{array}{l}\text { Dans le sens philosophique, l'observation } \\
\text { montre et l'expérience instruit. Cette } \\
\text { première distinction va nous servir de point } \\
\text { de départ pour examiner les } \\
\text { définitions diverses qui ont été données de } \\
\text { l'observation et de l'expérience par les } \\
\text { philosophes et les médecins. }\end{array}$ & $\begin{array}{l}\text { No sentido filosófico, a observação mostra e } \\
\text { a experiência ensina. Esta primeira distinção } \\
\text { vai nos servir de ponto de partida para } \\
\text { examinar as diversas definições que foram } \\
\text { dadas à observação e à experiência pelos } \\
\text { filósofos e médicos. }\end{array}$ \\
\hline
\end{tabular}




\begin{tabular}{|l|l|}
\hline I & \\
$\begin{array}{l}\text { Définitions diverses de l'observation } \\
\text { et de l'expérience }\end{array}$ & $\begin{array}{l}\text { I } \\
\text { Definições diversas da observação e } \\
\text { da experiência }\end{array}$ \\
\hline $\begin{array}{l}\text { On a quelquefois semblé confondre } \\
\text { l'expérience avec l'observation. Bacon } \\
\text { paraît réunir ces deux choses quand il dit : « } \\
\text { L'observation et l'expérience pour amasser } \\
\text { les matériaux, l'induction et la déduction } \\
\text { pour les élaborer voilà les seules bonnes } \\
\text { machines intellectuelles.» }\end{array}$ & $\begin{array}{l}\text { Parece que algumas vezes se confundiu a } \\
\text { experiência com a observação. Bacon }\end{array}$ \\
“Observação e experiência para recolher os \\
materiais, indução e dedução para elaborá- \\
los: eis os únicos bons motores intelectuais".
\end{tabular}

${ }^{50}$ N.T. Francis Bacon (1561-1626), político e filósofo inglês, inovou ao associar o progresso humano aos avanços do conhecimento, propondo uma classificação das ciências, fundador do Empirismo, uma das mais importantes linhas do pensamento filosófico do período moderno, segundo o qual, para que um conhecimento seja aceito, ele precisa ser sustentado por uma demonstração baseada na experiência. Sua forma de pensar, segundo a qual a busca do conhecimento e o entendimento da natureza devem partir de uma ideia teórica que deve ser verificada e estudada de maneira prática teve grande influência sobre os pensamentos de Claude Bernard e sua proposta de método experimental. Mais detalhes sobre a vida e obra de Bacon podem ser vistos em http://cours-dephilosophie.fr/ressources/les-philosophes/bacon/

${ }^{51}$ N.T. savant s.m. estudioso, especialista, erudito, expert, douto, instruído, competente, pesquisador, cientista, erudito.

Entre todas as acepções, a primeira foi escolhida por se adequar melhor ao que ele procura dizer a respeito do indivíduo que tira da experiência e do trabalho científico seus conhecimentos. Podemos entender também que ele utiliza este termo todas as vezes em que ele quer se referir ao cientista que realiza experimentos em laboratório e dele tira ensinamentos, isto é, o pesquisador científico.

52 N.T. Johann Georg Zimmermann (1728-1795), médico suíço conhecido pela obra Traité sur l'expérience en médecine, citada por Claude Bernard, na qual ele se propõe a construir um novo método diagnóstico, a partir de experiências médicas do passado e de seu tempo e de observações precisas dos sintomas (EMCH-DÉRIAZ, A. A propos de l'expérience en médecine de Zimmermann. Bulletin Canadien d'Histoire de la Médecine, vol. 9, p. 3-15, 1992.

Disponível em: http://www.cbmh.ca/index.php/cbmh/article/view/259/258) 


\begin{tabular}{|c|c|}
\hline $\begin{array}{l}\text { que l'on fait dans le dessein de savoir si une } \\
\text { chose est ou n'est point. " }\end{array}$ & $\begin{array}{l}\text { tentativa que se faz com o propósito de } \\
\text { saber se uma coisa faz ou não sentido" } 53\end{array}$ \\
\hline $\begin{array}{l}\text { Cette définition représente une opinion } \\
\text { assez généralement adoptée. D'après elle, } \\
\text { l'observation serait la constatation des } \\
\text { choses ou des phénomènes tels que la } \\
\text { nature nous les offre ordinairement, tandis } \\
\text { que l'expérience serait la constatation de } \\
\text { phénomènes créés ou déterminés par } \\
\text { l'expérimentateur. Il y aurait à établir de } \\
\text { cette manière une sorte d'opposition entre } \\
\text { l'observateur et l'expérimentateur ; le } \\
\text { premier étant passif dans la production des } \\
\text { phénomènes, le second y prenant, au } \\
\text { contraire, une part directe et active. Cuvier } \\
\text { a exprimé cette même pensée en disant : } \\
\text { "L'observateur écoute la nature ; } \\
\text { l'expérimentateur l'interroge et la force à se } \\
\text { dévoiler. " }\end{array}$ & $\begin{array}{l}\text { Esta definição representa uma opinião } \\
\text { geralmente bastante adotada. Segundo ela, } \\
\text { a observação seria a constatação das coisas } \\
\text { ou dos fenômenos da forma como nos são } \\
\text { mostrados habitualmente pela natureza, ao } \\
\text { passo que a experiência seria a constatação } \\
\text { de fenômenos criados ou determinados pelo } \\
\text { experimentador. Seria preciso estabelecer, } \\
\text { dessa maneira, uma espécie de oposição } \\
\text { entre o observador e o experimentador; o } \\
\text { primeiro sendo passivo na produção dos } \\
\text { fenômenos, o segundo, ao contrário, dela } \\
\text { participando de forma direta e ativa. } \\
\text { Cuvier }{ }^{54} \text { exprimiu esse mesmo pensamento } \\
\text { dizendo: "O observador escuta a natureza; o } \\
\text { experimentador a interroga e a força a se } \\
\text { desvendar". }\end{array}$ \\
\hline $\begin{array}{l}\text { Au premier abord, et quand on considère les } \\
\text { choses d'une manière générale, cette } \\
\text { distinction entre l'activité de } \\
\text { l'expérimentateur et la passivité de } \\
\text { l'observateur paraît claire et semble devoir } \\
\text { être facile à établir. Mais, dès qu'on descend } \\
\text { dans la pratique expérimentale, on trouve } \\
\text { que, dans beaucoup de cas, cette séparation } \\
\text { est très difficile à faire et que parfois même } \\
\text { elle entraîne de l'obscurité. Cela résulte, ce } \\
\text { me semble, de ce que l'on a confondu l'art } \\
\text { de l'investigation, qui recherche et constate } \\
\text { les faits, avec l'art du raisonnement, qui les } \\
\text { met en œuvre logiquement pour la } \\
\text { recherche de la vérité. Or, dans } \\
\text { l'investigation il peut y avoir à la fois activité }\end{array}$ & $\begin{array}{l}\text { Numa primeira abordagem, e quando se } \\
\text { consideram as coisas de uma maneira geral, } \\
\text { a distinção entre a atividade do } \\
\text { experimentador e a passividade do } \\
\text { observador parece clara e aparentemente } \\
\text { fácil de se estabelecer. No entanto, a partir } \\
\text { do momento que se entra na prática } \\
\text { experimental, descobre-se que, em muitos } \\
\text { casos, essa distinção é muito difícil de ser } \\
\text { feita e que por vezes ela até acarreta } \\
\text { obscuridade. Isto resulta, me parece, do fato } \\
\text { de que se confundiu a arte da investigação, } \\
\text { que busca e constata os fatos, com a arte do } \\
\text { raciocínio, que os opera logicamente em } \\
\text { busca da verdade. Logo, na investigação } \\
\text { pode haver ao mesmo tempo atividade do }\end{array}$ \\
\hline
\end{tabular}

53 ZIMMERMANN, Traité sur l'expérience en médecine. Paris, 1774, t. I, p. 45.

${ }^{54}$ N.T. Georges Cuvier (1769-1832), naturalista francês cuja visão sobre os organismos vivos era a de que estes resultavam, em seu conjunto, do funcionamento integrado de cada uma de suas partes. Nenhuma delas poderia ser modificada, sem interferir no funcionamento das demais. Anatomista, considerado o fundador da Anatomia Funcional, isto é, interessado no funcionamento dos órgãos e sistemas, lançado os primórdios das ideias a respeito do funcionamento do organismo, ajudando assim a abrir o campo da Fisiologia. Mais informações a respeito de sua vida e obra em: http://www.ucmp.berkeley.edu/history/cuvier.html 


\begin{tabular}{|c|c|}
\hline $\begin{array}{l}\text { de l'esprit et des sens, soit pour faire des } \\
\text { observations, soit pour faire des } \\
\text { expériences. }\end{array}$ & $\begin{array}{l}\text { espírito e dos sentidos, seja para fazer } \\
\text { observações, seja para fazer experiências. }\end{array}$ \\
\hline $\begin{array}{l}\text { En effet, si l'on voulait admettre que } \\
\text { l'observation est caractérisée par cela seul } \\
\text { que le savant constate des phénomènes que } \\
\text { la nature a produits spontanément et sans } \\
\text { son intervention, on ne pourrait cependant } \\
\text { pas trouver que l'esprit comme la main reste } \\
\text { toujours inactif dans l'observation, et l'on } \\
\text { serait amené à distinguer sous ce rapport } \\
\text { deux sortes d'observations : les unes } \\
\text { passives, les autres actives. Je suppose, par } \\
\text { exemple, ce qui est souvent arrivé, qu'une } \\
\text { maladie endémique quelconque survienne } \\
\text { dans un pays et s'offre à l'observation d'un } \\
\text { médecin. C'est là une observation } \\
\text { spontanée ou passive que le médecin fait } \\
\text { par hasard et sans y être conduit par aucune } \\
\text { idée préconçue. Mais si, après avoir observé } \\
\text { les premiers cas, il vient à l'idée de ce } \\
\text { médecin que la production de cette maladie } \\
\text { pourrait bien être en rapport avec certaines } \\
\text { circonstances météorologiques ou } \\
\text { hygiéniques spéciales; alors le médecin va } \\
\text { en voyage et se transporte dans d'autres } \\
\text { pays où règne la même maladie, pour voir si } \\
\text { elle s'y développe dans les mêmes } \\
\text { conditions. Cette seconde observation, } \\
\text { faite en vue d'une idée préconçue sur la } \\
\text { nature et la cause de la maladie, est ce qu'il } \\
\text { faudrait évidemment appeler une } \\
\text { observation provoquée ou active. J'en dirai } \\
\text { autant d'un astronome qui, regardant le ciel, } \\
\text { découvre une planète qui passe par hasard } \\
\text { devant sa lunette; il a fait là une observation } \\
\text { fortuite et passive, c'est-à-dire sans idée } \\
\text { préconçue. Mais si, après avoir constaté les }\end{array}$ & $\begin{array}{l}\text { Na verdade, se se quisesse admitir que a } \\
\text { observação é caracterizada apenas por } \\
\text { aquilo que o estudioso }{ }^{55} \text { constata dos } \\
\text { fenômenos que a natureza produziu } \\
\text { espontaneamente e sem sua intervenção, } \\
\text { não se poderia, no entanto, pensar que o } \\
\text { espírito, como a mão, permanece sempre } \\
\text { inativo na observação, o que levaria a } \\
\text { distinguir, sob essa relação, dois tipos de } \\
\text { observações: as passivas e as ativas. Eu } \\
\text { suponho, por exemplo, algo que acontece } \\
\text { com frequência, que uma doença endêmica } \\
\text { qualquer apareça num país e se mostre }{ }^{56} \text { à } \\
\text { observação de um médico. Essa é uma } \\
\text { observação espontânea ou passiva que o } \\
\text { médico faz por acaso e sem ter sido a ela } \\
\text { conduzido por nenhuma ideia preconcebida. } \\
\text { Mas se, após ter observado os primeiros } \\
\text { casos, vem à mente desse médico a ideia de } \\
\text { que a produção dessa doença bem poderia } \\
\text { ter uma relação com certas circunstâncias } \\
\text { meteorológicas ou higiênicas especiais, } \\
\text { então o médico parte em viagem e vai para } \\
\text { outros países onde reina a mesma doença } \\
\text { para ver se ela se desenvolve ali sob as } \\
\text { mesmas condições. } \\
\text { obsta segunda } \\
\text { preconção, feita a partir de uma ideia } \\
\text { doença, é o que seria preciso evidentemente } \\
\text { denominar uma observação produzida ou } \\
\text { ativa. Eu diria o mesmo de um astrônomo } \\
\text { que, olhando o céu, descobre um planeta } \\
\text { que passa por acaso diante de sua luneta; ele } \\
\text { fez uma observação fortuita e passiva, isto é, } \\
\text { sem uma ideia preconcebida. Mas se, após }\end{array}$ \\
\hline
\end{tabular}

\footnotetext{
55 N.T. Estudioso: neste caso específico, esse é o termo que correlacionaríamos hoje ao nosso pesquisador. É uma outra forma de referir-se a savant, como já comentado na nota 12.

${ }^{56}$ N.T. s'offrir v.pron. apresentar-se, mostrar-se, expor-se.

S'offrir foi traduzido por mostrar-se. Em todas as ocorrências, esse foi o termo escolhido em português por se mostrar o mais adequado em todos os contextos em que aparece.
} 
perturbations d'une planète, l'astronome en est venu à faire des observations pour en rechercher la raison, je dirai qu'alors l'astronome fait des observations actives, c'est-à-dire des observations provoquées par une idée préconçue sur la cause de la perturbation. On pourrait multiplier à l'infini les citations de ce genre pour prouver que, dans la constatation des phénomènes naturels qui s'offrent à nous, l'esprit est tantôt passif et tantôt actif, ce qui signifie, en d'autres termes, que l'observation se fait tantôt sans idée préconçue et par hasard, et tantôt avec idée préconçue, c'est-à-dire avec intention de vérifier l'exactitude d'une vue de l'esprit.

D'un autre côté, si l'on admettait, comme il a été dit plus haut, que l'expérience est caractérisée par cela seul que le savant constate des phénomènes qu'il a provoqués artificiellement et qui naturellement ne se présentaient pas à lui, on ne saurait trouver non plus que la main de l'expérimentateur doive toujours intervenir activement pour opérer l'apparition de ces phénomènes. On a vu, en effet, dans certains cas, des accidents où la nature agissait pour lui, et là encore nous serions obligés de distinguer, au point de vue de l'intervention manuelle, des expériences actives et des expériences passives. Je suppose qu'un physiologiste veuille étudier la digestion et savoir ce qui se passe dans l'estomac d'un animal vivant; il divisera les parois du ventre et de l'estomac d'après des règles opératoires connues, et il établira ce qu'on appelle une fistule gastrique. Le physiologiste croira certainement avoir fait une expérience ter constatado as perturbações ${ }^{57}$ de um planeta, o astrônomo começa a fazer observações para pesquisar o motivo, eu direi, então, que o astrônomo faz observações ativas, isto é, observações produzidas por uma ideia preconcebida sobre a causa da perturbação. Seria possível multiplicar ao infinito as citações desse tipo para provar que, na constatação dos fenômenos naturais que se mostram para nós, o espírito é ora passivo e ora ativo, o que significa, em outros termos, que a observação se faz tanto sem ideias preconcebidas e por acaso quanto por ideias preconcebidas, isto é, com a intenção de verificar a exatidão de uma visão do espírito.

Por outro lado, se se admitisse, como já foi dito, que a experiência é caracterizada apenas por aquilo que o estudioso constata dos fenômenos que ele produziu artificialmente e que não se apresentavam a ele naturalmente, não se poderia achar também que a mão do experimentador sempre deve intervir ativamente para gerar o aparecimento desses fenômenos. Viramse, com efeito, em alguns casos, acidentes em que a natureza agia em seu lugar; e mesmo assim seríamos obrigados a distinguir, sob o ponto de vista da intervenção manual, experiências ativas e experiências passivas. Suponho que um fisiologista queira estudar a digestão e saber o que se passa dentro do estômago de um animal vivo; ele dividirá as paredes do ventre e do estômago de acordo com regras operatórias conhecidas e estabelecerá o que é chamado de fístula gástrica. O fisiologista acreditará certamente ter realizado uma

\footnotetext{
${ }^{57}$ N.T. perturbation s.f. perturbação, desordem, confusão, desorganização. O termo escolhido, perturbação, é bastante utilizado em ciência. Foi encontrado em relatos científicos, associado a perturbação: planetária, quântica, gravitacional, geobiológica, funcional, física, sonora, disfórica, pré-menstrual, dismórfica corporal, circulatória, dos ciclos biológicos, do equilíbrio químico, entre outros. Por esta razão, foi mantida assim a sua tradução para o português.
} 
parce qu'il est intervenu activement pour faire apparaître des phénomènes qui ne s'offraient pas naturellement à ses yeux. Mais maintenant je demanderai : le docteur $W$. Beaumont fit-il une expérience quand il rencontra ce jeune chasseur canadien qui, après avoir reçu à bout portant un coup de fusil dans l'hypocondre gauche, conserva, à la chute de l'eschare, une large fistule de l'estomac par laquelle on pouvait voir dans l'intérieur de cet organe ? Pendant plusieurs années, le docteur Beaumont, qui avait pris cet homme à son service, put étudier de visu les phénomènes de la digestion gastrique, ainsi qu'il nous l'a fait connaître dans l'intéressant journal qu'il nous a donné à ce sujet. Dans le premier cas, le physiologiste a agi en vertu de l'idée préconçue d'étudier les phénomènes digestifs et il a fait une expérience active. Dans le second cas, un accident a opéré la fistule à l'estomac, et elle s'est présentée fortuitement au docteur Beaumont qui dans notre définition aurait fait une expérience passive, s'il est permis d'ainsi parler. Ces exemples prouvent donc que, dans la constatation des phénomènes qualifiés d'expérience, l'activité manuelle de l'expérimentateurn'intervient pas toujours ; experiência porque ele interveio ativamente para fazer aparecer fenômenos que não se mostravam naturalmente a seus olhos. Mas agora eu pergunto: teria o doutor W. Beaumont ${ }^{58}$ feito uma experiência quando encontrou aquele jovem caçador canadense que, após ter recebido um tiro de fuzil à queima roupa no hipocôndrio ${ }^{59}$ esquerdo, conservou, com a queda da escara ${ }^{60}$, uma grande fístula do estômago pela qual se podia ver o interior desse órgão? Durante vários anos, o doutor Beaumont, que se serviu desse homem para seus trabalhos, pôde estudar de visu os fenômenos da digestão gástrica, como ele próprio nos ensina no interessante diário que nos deixou a esse respeito ${ }^{61}$. No primeiro caso, o fisiologista agiu em virtude da ideia preconcebida de estudar os fenômenos digestivos e fez uma experiência ativa. No segundo caso, um acidente gerou a fístula no estômago e ela se apresentou fortuitamente ao doutor Beaumont, que, segundo a nossa definição, teria feito uma experiência passiva, se assim se pode dizer. Portanto, esses exemplos provam que, na constatação dos fenômenos qualificados como experiência, a atividade manual do

\footnotetext{
${ }^{58}$ N.T. William Beaumont (1785-1853), cirurgião das forças armadas norte-americanas que ficou conhecido por suas experiências sobre a função gástrica. Claude Bernard utilizou os procedimentos descritos em uma de suas publicações, para utilizá-lo como exemplo de um experimento em que houve a interferência de fatores externos e que, portanto, não se limitou à simples observação. Mais detalhes sobre a obra deste médico podem ser encontrados em:

http://www.james.com/beaumont/dr life.htm

${ }^{59}$ N.T. hypocondre. s.m hipocôndrio (direito ou esquerdo).

Em Anatomia, corresponde a cada uma das partes latero-superiores da parede abdominal situadas à direita e à esquerda do epigástrio e abaixo do rebordo costal (REY, 1999, p.405); em Anatomia, corresponde a uma das divisões da parede abdominal, situando-se abaixo das costelas, no quadrante superior do abdome.

${ }^{60}$ N.T. eschare s.f escara.

Em Patologia, corresponde à crosta escura e mais ou menos espessa que se forma na pele pela necrose dos tecidos em consequência de uma queimadura, ação de cáustico ou compressão prolongada (REY, 1999, p.281); um tipo especial de lesão da pele, uma forma de ferida que surge em regiões do corpo que permanecem apoiadas por muito tempo, geralmente em pessoas acamadas ou que vivem em cadeiras de rodas.

${ }^{61}$ W. BEAUMONT, Experimentation and Observation on the Gastric Juice and the Physiological Digestion. Boston, 1834.
} 


\begin{tabular}{|c|c|}
\hline $\begin{array}{l}\text { puisqu'il arrive que ces phénomènes } \\
\text { peuvent, ainsi que nous le voyons, se } \\
\text { présenter comme des observations passives } \\
\text { ou fortuites. }\end{array}$ & $\begin{array}{l}\text { experimentador nem sempre intervém, pois, } \\
\text { como vemos, esses fenômenos podem se } \\
\text { apresentar como observações passivas ou } \\
\text { fortuitas. }\end{array}$ \\
\hline $\begin{array}{l}\text { Mais il est des physiologistes et des } \\
\text { médecins qui ont caractérisé un peu } \\
\text { différemment l'observation et l'expérience. } \\
\text { Pour eux l'observation consiste dans la } \\
\text { constatation de tout ce qui est normal et } \\
\text { régulier. Peu importe que l'investigateur ait } \\
\text { provoqué lui-même, ou par les mains d'un } \\
\text { autre, ou par un accident, l'apparition des } \\
\text { phénomènes, dès qu'il les considère sans les } \\
\text { troubler et dans leur état normal, c'est une } \\
\text { observation qu'il fait. Ainsi dans les deux } \\
\text { exemples de fistule gastrique que nous } \\
\text { avons cités précédemment, il y aurait eu, } \\
\text { d'après ces auteurs, observation, parce que } \\
\text { dans les deux cas on a eu sous les yeux les } \\
\text { phénomènes digestifs conformes à l'état } \\
\text { naturel. La fistule n'a servi qu'à mieux voir, } \\
\text { et à faire l'observation dans de meilleures } \\
\text { conditions. }\end{array}$ & $\begin{array}{l}\text { Mas existem fisiologistas e médicos que } \\
\text { caracterizaram um pouco diferentemente a } \\
\text { observação e a experiência. Para eles, a } \\
\text { observação consiste na constatação de tudo } \\
\text { o que é normal e regular. Pouco importa se } \\
\text { o aparecimento de fenômenos tenha sido } \\
\text { produzido pelo próprio investigador, pelas } \\
\text { mãos de outro ou por um acidente; desde } \\
\text { que ele os considere sem perturbá-los e em } \\
\text { seu estado normal, o que ele faz é uma } \\
\text { observação. Assim, nos dois exemplos de } \\
\text { fístulas gástricas que citamos } \\
\text { anteriormente, teria ocorrido, segundo } \\
\text { esses autores, observação, porque nos dois } \\
\text { casos apresentaram-se diante dos olhos } \\
\text { fenômenos digestivos em conformidade } \\
\text { como estado natural. A fístula apenas serviu } \\
\text { para que se pudesse ver melhor e para } \\
\text { garantir a observação em melhores } \\
\text { condições. }\end{array}$ \\
\hline $\begin{array}{l}\text { L'expérience, au contraire, implique, d'après } \\
\text { les mêmes physiologistes, l'idée d'une } \\
\text { variation ou d'un trouble intentionnellement } \\
\text { apportés par l'investigateur dans les } \\
\text { conditions des phénomènes naturels. Cette } \\
\text { définition répond en effet à un groupe } \\
\text { nombreux d'expériences que l'on pratique } \\
\text { en physiologie et qui pourraient s'appeler } \\
\text { expériences par destruction. Cette manière } \\
\text { d'expérimenter, qui remonte à Galien, est la } \\
\text { plus simple, et elle devait se présenter à } \\
\text { l'esprit des anatomistes désireux de }\end{array}$ & $\begin{array}{l}\text { A experiência, ao contrário, implica, segundo } \\
\text { os mesmos fisiologistas, a ideia de uma } \\
\text { variação ou de uma desordem trazidos } \\
\text { intencionalmente pelo investigador nas } \\
\text { condições dos fenômenos naturais. Esta } \\
\text { definição responde, na verdade, a um } \\
\text { grande número de experiências que se } \\
\text { praticam em fisiologia e que poderiam ser } \\
\text { chamadas de experiências por destruição. } \\
\text { Esta maneira de experimentar, que remonta } \\
\text { a Galeno }{ }^{62} \text {, é a mais simples, e devia se } \\
\text { apresentar ao espírito dos anatomistas }\end{array}$ \\
\hline
\end{tabular}

${ }^{62}$ N.T. Claudio Galeno (130dC- 200dC), médico e filósofo romano, de origem grega, realizava experimentos, praticando as primeiras dissecções em animais. Tornou-se médico oficial dos gladiadores. Seus ensinamentos foram utilizados por médicos ao longo de toda a Idade Média. Suas descrições anatômicas de ossos, músculos e nervos estabeleceram um marco na História da Anatomia. Escreveu mais de 400 livros. Mais detalhes podem ser encontrados em: http://www.dec.ufcg.edu.br/biografias/ClaudiGa.html 
connaître sur le vivant l'usage des parties qu'ils avaient isolées par la dissection sur le cadavre. Pour cela, on supprime un organe sur le vivant par la section ou par l'ablation, et l'on juge, d'après le trouble produit dans l'organisme entier ou dans une fonction spéciale, de l'usage de l'organe enlevé. Ce procédé expérimental essentiellement analytique est mis tous les jours en pratique en physiologie. Par exemple, l'anatomie avait appris que deux nerfs principaux se distribuent à la face : Le facial et la cinquième paire ; pour connaître leurs usages, on les a coupés successivement. Le résultat a montré que la section du facial amène la perte du mouvement, et la section de la cinquième paire, la perte de la sensibilité. D'où l'on a conclu que le facial est le nerf moteur de la face et la cinquième paire le nerf sensitif.

Nous avons dit qu'en étudiant la digestion par l'intermédiaire d'une fistule, on ne fait qu'une observation, suivant la définition que nous examinons. Mais si, après avoir établi la fistule, on vient à couper les nerfs de l'estomac avec l'intention de voir les modifications qui en résultent dans la fonction digestive, alors, suivant la même manière de voir, on fait une expérience, parce qu'on cherche à connaître la fonction d'une partie d'après le trouble que sa suppression entraîne. Ce qui peut se résumer en disant que dans l'expérience il faut porter un jugement par comparaison de deux faits, l'un normal, l'autre anormal.

Cette définition de l'expérience suppose nécessairement que l'expérimentateur doit desejosos de conhecer, nos vivos, o funcionamento das partes que eles tinham isolado do cadáver pela dissecção. Para tanto, suprime-se um órgão do indivíduo vivo pela secção ou ablação e avalia-se ${ }^{63}$, de acordo com a desordem produzida no organismo inteiro ou numa função específica, o funcionamento do órgão removido. Este procedimento experimental essencialmente analítico é posto em prática todos os dias em fisiologia. Por exemplo, a anatomia tinha descoberto que dois nervos principais se distribuem na face: o facial e o quinto par; para conhecer suas funções, eles foram cortados sucessivamente. $O$ resultado mostrou que a secção do facial leva à perda do movimento e a secção do quinto par, à perda da sensibilidade. Daí se concluiu que o facial é o nervo motor da face e o quinto par, o nervo sensitivo.

Nós dissemos que, ao estudar a digestão por meio de uma fístula, o que se faz é apenas uma observação, seguindo a definição que examinamos. Mas se, após ter estabelecido a fístula, cortam-se os nervos do estômago com a intenção de observar as modificações que disso resultam na função digestiva, então, seguindo a mesma visão, realiza-se uma experiência, porque se procura conhecer a função de uma parte de acordo com a desordem que sua supressão acarreta. O que pode ser resumido dizendo que na experiência é preciso produzir uma avaliação por comparação de dois fatos, um normal, outro anormal.

Essa definição da experiência supõe necessariamente que o experimentador

\footnotetext{
${ }^{63}$ N.T. juger v.t. julgar, estimar, avaliar, apreciar, examinar. O verbo juger foi traduzido por avaliar e jugement por avaliação, que julgamos serem os termos em português que melhor se aplicam a todos os contextos em que eles ocorrem (avaliar o organismo, avaliar o experimento, avaliar uma comparação de dois fatos, avaliar os fatos, avaliar a ideia, entre outros)
} 
pouvoir toucher le corps sur lequel il veut agir, soit en le détruisant, soit en le modifiant, afin de connaître ainsi le rôle qu'il remplit dans les phénomènes de la nature. C'est même, comme nous le verrons plus loin, sur cette possibilité d'agir ou non sur les corps que reposera exclusivement la distinction des sciences dites d'observation et des sciences dites expérimentales.

Mais si la définition de l'expérience que nous venons de donner diffère de celle que nous avons examinée en premier lieu, en ce qu'elle admet qu'il n'y a expérience que lorsqu'on peut faire varier ou qu'on décompose par une sorte d'analyse le phénomène qu'on veut connaître, elle lui ressemble cependant en ce qu'elle suppose toujours comme elle une activité intentionnelle de l'expérimentateur dans la production de ce trouble des phénomènes. Or, il sera facile de montrer que souvent l'activité intentionnelle de l'opérateur peut être remplacée par un accident. On pourrait donc encore distinguer ici, comme dans la première définition, des troubles survenus intentionnellement et des troubles survenus spontanément et non intentionnellement. En effet, reprenant notre exemple dans lequel le physiologiste coupe le nerf facial pour en connaître les fonctions, je suppose, ce qui est arrivé souvent, qu'une balle, un coup de sabre, une carie du rocher viennent à couper ou à détruire le facial ; il en résultera fortuitement une paralysie du mouvement, c'est-à-dire un trouble qui est exactement le même que celui que le deve poder tocar o corpo sobre o qual ele quer agir, seja destruindo-o, seja modificando-o, a fim de conhecer, assim, o papel que ele desempenha nos fenômenos da natureza. É justamente, como veremos mais adiante, sobre essa possibilidade de agir ou não sobre os corpos que residirá exclusivamente a distinção das ciências ditas de observação e das ciências ditas experimentais.

Mas, se a definição da experiência que acabamos de dar difere daquela que examinamos em primeiro lugar pelo fato de que ela admite que só há experiência quando se pode produzir uma variação ou quando se decompõe, por um tipo de análise, o fenômeno que se quer conhecer, no entanto a ela se assemelha pelo fato de, como ela, sempre supor uma atividade intencional do experimentador na produção dessa desordem dos fenômenos. Logo, será fácil mostrar que frequentemente a atividade intencional do operador pode ser substituída por um acidente. Assim, seria possível ainda distinguir aqui, como na primeira definição, desordens surgidas intencionalmente e desordens surgidas espontaneamente e não intencionalmente. De fato, retomando nosso exemplo no qual o fisiologista corta o nervo facial para conhecer suas funções, eu posso supor, o que aconteceu muitas vezes, que uma bala, um golpe de sabre, uma fratura no rochedo ${ }^{64}$ do temporal venham a cortar ou destruir o facial; disso resultará fortuitamente uma paralisia do movimento, isto é, uma desordem, que é exatamente a

\footnotetext{
${ }^{64}$ N.T. rocher s.m.rochedo.

Em Anatomia, corresponde à peça óssea de forma piramidal que constitui a parte interna do osso temporal. Sin. parte petrosa do osso temporal (REY, 1999, p. 680) A imagem que mostra a localização desse osso no crânio pode ser vista em:

http://www.auladeanatomia.com/osteologia/craniocomoumtodo.htm
} 


\begin{tabular}{|c|c|}
\hline $\begin{array}{l}\text { physiologiste aurait déterminé } \\
\text { intentionnellement. }\end{array}$ & $\begin{array}{l}\text { mesma que o fisiologista teria determinado } \\
\text { intencionalmente. }\end{array}$ \\
\hline $\begin{array}{l}\text { Il en sera de même d'une infinité de lésions } \\
\text { pathologiques qui sont de véritables } \\
\text { expériences dont le médecin et le } \\
\text { physiologiste tirent profit, sans que } \\
\text { cependant il y ait de leur part aucune } \\
\text { préméditation pour provoquer ces lésions } \\
\text { qui sont le fait de la maladie. Je signale dès } \\
\text { à présent cette idée parce qu'elle nous sera } \\
\text { utile plus tard pour prouver que la médecine } \\
\text { possède de véritables expériences, bien que } \\
\text { ces dernières soient spontanées et non } \\
\text { provoquées par le médecin. }\end{array}$ & $\begin{array}{l}\text { Será esse também o caso de uma infinidade } \\
\text { de lesões patológicas que são verdadeiras } \\
\text { experiências das quais o médico e o } \\
\text { fisiologista tiram proveito, sem que, no } \\
\text { entanto, haja de sua parte qualquer } \\
\text { premeditação para produzir }{ }^{65} \text { essas lesões } \\
\text { que são a causa da doença. Assinalo desde já } \\
\text { essa ideia porque ela nos será útil mais } \\
\text { adiante para provar que a medicina possui } \\
\text { verdadeiras experiências, ainda que sejam } \\
\text { espontâneas e não produzidas pelo } \\
\text { médico. }{ }^{66}\end{array}$ \\
\hline $\begin{array}{l}\text { Je ferai encore une remarque qui servira de } \\
\text { conclusion. Si en effet on caractérise } \\
\text { l'expérience par une variation ou par un } \\
\text { trouble apportés dans un phénomène, ce } \\
\text { n'est qu'autant qu'on sous-entend qu'il faut } \\
\text { faire la comparaison de ce trouble avec } \\
\text { l'état normal. L'expérience n'étant en effet } \\
\text { qu'un jugement, elle exige nécessairement } \\
\text { comparaison entre deux choses, et ce qui } \\
\text { est intentionnel ou actif dans l'expérience, } \\
\text { c'est réellement la comparaison que l'esprit } \\
\text { veut faire. Or, que la perturbation soit } \\
\text { produite par accident ou autrement, l'esprit } \\
\text { de l'expérimentateur n'en compare pas } \\
\text { moins bien. Il n'est donc pas nécessaire que } \\
\text { l'un des faits à comparer soit considéré } \\
\text { comme un trouble; d'autant plus qu'il n'y a } \\
\text { dans la nature rien de troublé ni d'anormal ; } \\
\text { tout se passe suivant des lois qui sont } \\
\text { absolues, c'est-à-dire toujours normales et } \\
\text { déterminées. Les effets varient en raison des }\end{array}$ & $\begin{array}{l}\text { Farei ainda uma observação que servirá de } \\
\text { conclusão. Se se caracteriza efetivamente a } \\
\text { experiência por uma variação ou por uma } \\
\text { perturbação produzida num fenômeno, } \\
\text { subentende-se que isso só é possível se se } \\
\text { comparar essa desordem com o estado } \\
\text { normal. Sendo a experiência apenas uma } \\
\text { avaliação, ela exige necessariamente a } \\
\text { comparação entre duas coisas; e o que é } \\
\text { intencional ou ativo na experiência é } \\
\text { realmente a comparação que o espírito quer } \\
\text { fazer. Logo, seja a perturbação produzida } \\
\text { por acidente ou por outra coisa, a } \\
\text { comparação do espírito do experimentador } \\
\text { não será menos precisa. Portanto, não é } \\
\text { necessário que um dos fatos a comparar seja } \\
\text { considerado como uma desordem; ainda } \\
\text { mais porque não há na natureza nada de } \\
\text { desordenado ou de anormal; tudo se passa } \\
\text { de acordo com as leis que são absolutas, isto }\end{array}$ \\
\hline
\end{tabular}

${ }^{65}$ N.T. provoquer v. $t$. provocar, produzir, suscitar, ocasionar, determinar, causar.

O verbo provoquer foi traduzido por produzir, termo em português que se mostrou o mais adequado a todos os contextos em que ele ocorreu. Provoquer l'expérience, portanto, foi traduzido para o português por produzir a experiência. Os outros contextos em que aparece esse verbo são: produzir fatos, produzir observações, produzir lesões.

${ }^{66}$ LALLEMAND, Propositions de pathologie tendant à éclairer plusieurs points de physiologie. Thèse. Paris, 1818 ; 2e édition, 1824. 


\begin{tabular}{|c|c|}
\hline $\begin{array}{l}\text { conditions qui les manifestent, mais les lois } \\
\text { ne varient pas. L'état physiologique et l'état } \\
\text { pathologique sont régis par les mêmes } \\
\text { forces, et ils ne diffèrent que par les } \\
\text { conditions particulières dans lesquelles la loi } \\
\text { vitale se manifeste. }\end{array}$ & $\begin{array}{l}\text { é, sempre normais e determinadas }{ }^{67} \text {. Os } \\
\text { efeitos variam em razão das condições que } \\
\text { os manifestam, mas as leis não variam. O } \\
\text { estado fisiológico e o estado patológico são } \\
\text { regidos pelas mesmas forças e eles diferem } \\
\text { apenas pelas condições particulares nas } \\
\text { quais a lei vital se manifesta. }\end{array}$ \\
\hline $\begin{array}{l}\text { II } \\
\text { Acquérir de l'expérience et s'appuyer } \\
\text { sur l'observation est autre chose que } \\
\text { faire des expériences et faire des } \\
\text { observations }\end{array}$ & $\begin{array}{l}\text { II } \\
\text { Adquirir experiência e apoiar-se na } \\
\text { observação é algo diferente de fazer } \\
\text { experiências e fazer observações }\end{array}$ \\
\hline $\begin{array}{l}\text { Le reproche général que j'adresserai aux } \\
\text { définitions qui précèdent, c'est d'avoir } \\
\text { donné aux mots un sens trop circonscrit en } \\
\text { ne tenant compte que de l'art de } \\
\text { l'investigation, au lieu d'envisager en même } \\
\text { temps l'observation et l'expérience comme } \\
\text { les deux termes extrêmes du raisonnement } \\
\text { expérimental. Aussi voyons-nous ces } \\
\text { définitions manquer de clarté et de } \\
\text { généralité. Je pense donc que, pour donner } \\
\text { à la définition toute son utilité et toute sa } \\
\text { valeur, il faut distinguer ce qui appartient au } \\
\text { procédé d'investigation employé pour } \\
\text { obtenir les faits, de ce qui appartient au } \\
\text { procédé intellectuel qui les met en œuvre et } \\
\text { en fait à la fois le point d'appui et le criterium } \\
\text { de la méthode expérimentale. }\end{array}$ & $\begin{array}{l}\text { A crítica geral que remeterei às definições } \\
\text { precedentes é a de ter dado às palavras um } \\
\text { sentido circunscrito demais, levando em } \\
\text { conta apenas a arte da investigação, em } \\
\text { lugar de considerar, ao mesmo tempo, a } \\
\text { observação e a experiência como os dois } \\
\text { termos extremos do raciocínio } \\
\text { experimental. Assim, vemos essas definições } \\
\text { carecerem de clareza e de generalidade. Eu } \\
\text { penso, portanto, que, para dar à definição } \\
\text { toda a sua utilidade e todo o seu valor, é } \\
\text { preciso distinguir aquilo que pertence ao } \\
\text { procedimento de investigação empregado } \\
\text { para obter os fatos daquilo que pertence ao } \\
\text { procedimento intelectual que os executa e } \\
\text { faz deles, ao mesmo tempo, o ponto de } \\
\text { apoio e o criterium do método experimental. }\end{array}$ \\
\hline $\begin{array}{l}\text { Dans la langue française, le mot expérience } \\
\text { au singulier signifie d'une manière générale } \\
\text { et abstraite l'instruction acquise par l'usage } \\
\text { de la vie. Quand on applique à un médecin }\end{array}$ & $\begin{array}{l}\text { Na língua francesa, a palavra expérience } \\
\text { (doravante experiência), no singular, } \\
\text { significa, de uma maneira geral e abstrata, a } \\
\text { instrução }{ }^{68} \text { adquirida pela prática da vida. }\end{array}$ \\
\hline
\end{tabular}

${ }^{67}$ N.T. Embora Claude Bernard não use ainda aqui a palavra determinismo, ele já começa a introduzir a ideia do determinismo em ciências biológicas, algo que ele irá discutir e que voltará a abordar ao longo de toda a obra.

${ }^{68}$ N.T. Instruction s.f. instrução, saber, experiência, conhecimento, aprendizado, ensinamento. 


\begin{tabular}{|c|c|}
\hline $\begin{array}{l}\text { le mot expérience pris au singulier, il } \\
\text { exprime l'instruction qu'il a acquise par } \\
\text { l'exercice de la médecine. Il en est de même } \\
\text { pour les autres professions, et c'est dans ce } \\
\text { sens que l'on dit qu'un homme a acquis de } \\
\text { l'expérience, qu'il a de l'expérience. Ensuite } \\
\text { on a donné par extension et dans un sens } \\
\text { concret le nom d'expériences aux faits qui } \\
\text { nous fournissent cette instruction } \\
\text { expérimentale des choses. }\end{array}$ & $\begin{array}{l}\text { Quando a palavra experiência no singular se } \\
\text { relaciona a um médico, ela exprime a } \\
\text { instrução que ele adquiriu pelo exercício da } \\
\text { medicina. Isso é assim também para as } \\
\text { outras profissões, e é nesse sentido que se } \\
\text { dizque um homem adquiriu experiência, que } \\
\text { ele tem experiência. Em seguida, foi dado, } \\
\text { por extensão e num sentido concreto, o } \\
\text { nome de experiências aos fatos que nos } \\
\text { fornecem essa instrução experimental das } \\
\text { coisas. }\end{array}$ \\
\hline $\begin{array}{l}\text { Le mot observation, au singulier, dans son } \\
\text { acception générale et abstraite, signifie la } \\
\text { constatation exacte d'un fait à l'aide de } \\
\text { moyens d'investigation et d'études } \\
\text { appropriées à cette constatation. Par } \\
\text { extension et dans un sens concret, on a } \\
\text { donné aussi le nom d'observations aux faits } \\
\text { constatés, et c'est dans ce sens que l'on dit } \\
\text { observations médicales, observations } \\
\text { astronomiques, etc. }\end{array}$ & $\begin{array}{l}\text { A palavra observation (doravante } \\
\text { observação), no singular, em sua acepção } \\
\text { geral e abstrata, significa a constatação } \\
\text { exata de um fato com a ajuda de meios de } \\
\text { investigação e de estudos apropriados a essa } \\
\text { constatação. Por extensão e num sentido } \\
\text { concreto, foi dado também o nome de } \\
\text { observações aos fatos constatados, e é nesse } \\
\text { sentido que se diz observações médicas, } \\
\text { observações astronômicas, etc. }\end{array}$ \\
\hline $\begin{array}{l}\text { Quand on parle d'une manière concrète, et } \\
\text { quand on dit faire des expériences ou faire } \\
\text { des observations, cela signifie qu'on se livre } \\
\text { à l'investigation et à la recherche, que l'on } \\
\text { tente des essais, des épreuves, dans le but } \\
\text { d'acquérir des faits dont l'esprit, à l'aide du } \\
\text { raisonnement, pourra tirer une } \\
\text { connaissance ou une instruction. }\end{array}$ & $\begin{array}{l}\text { Quando se fala de maneira concreta e } \\
\text { quando se diz fazer experiências ou fazer } \\
\text { observações, isso significa entregar-se à } \\
\text { investigação e à pesquisa, produzir testes, } \\
\text { comprovações, com o objetivo de obter } \\
\text { fatos dos quais o espírito, com a ajuda do } \\
\text { raciocínio, poderá extrair um conhecimento } \\
\text { ou uma instrução. }\end{array}$ \\
\hline $\begin{array}{l}\text { Quand on parle d'une manière abstraite et } \\
\text { quand on dit s'appuyer sur l'observation et } \\
\text { acquérir de l'expérience, cela signifie que } \\
\text { l'observation est le point d'appui de l'esprit } \\
\text { qui raisonne, et l'expérience le point d'appui }\end{array}$ & $\begin{array}{l}\text { Quando se fala de maneira abstrata e } \\
\text { quando se diz apoiar-se na observação e } \\
\text { adquirir experiência, isso significa que a } \\
\text { observação é o ponto de apoio do espírito } \\
\text { que raciocina e a experiência, o ponto de }\end{array}$ \\
\hline
\end{tabular}

Claude Bernard usa várias vezes este termo, tanto na forma nominalizada, como aparece aqui, como na sua forma verbal (verbo Instruire). Embora este termo em português pudesse ser mais familiar ao leitor se fosse traduzido por saber ou conhecimento, resolvemos mantê-lo na forma mais próxima possível daquela utilizada pelo autor, tendo claro que ele o utiliza na acepção de "dotar de instrumentos", "fornecer o instrumental". Além disso, esta opção pretendeu manter a uniformidade dos termos nas suas duas formas (nominalizada e verbal), o que não seria possível se usássemos os termos saber ou experiência, cuja forma verbal, que aparece mais adiante no texto, soaria estranha na língua de chegada. 


\begin{abstract}
de l'esprit qui conclut ou mieux encore le fruit d'un raisonnement juste appliqué à l'interprétation des faits. D'où il suit que l'on peut acquérir de l'expérience sans faire des expériences, par cela seul qu'on raisonne convenablement sur les faits bien établis, de même que l'on peut faire des expériences et des observations sans acquérir de l'expérience, si l'on se borne à la constatation des faits.
\end{abstract}

L'observation est donc ce qui montre les faits ; l'expérience est ce qui instruit sur les faits et ce qui donne de l'expérience relativement à une chose. Mais comme cette instruction ne peut arriver que par une comparaison et un jugement, c'est-à-dire par suite d'un raisonnement, il en résulte que l'homme seul est capable d'acquérir de l'expérience et de se perfectionner par elle.

"L'expérience, dit Goethe, corrige l'homme chaque jour. " Mais c'est parce qu'il raisonne juste et expérimentalement sur ce qu'il observe; sans cela il ne se corrigerait pas. L'homme qui a perdu la raison, l'aliéné, ne s'instruit plus par l'expérience, il ne raisonne plus expérimentalement. L'expérience est donc le privilège de la raison. "A l'homme seul appartient de vérifier ses pensées, de les ordonner; à I'homme seul appartient de corriger, de rectifier, d'améliorer, de perfectionner et de pouvoir ainsi tous les jours se rendre plus habile, plus sage et plus heureux. Pour I'homme seul, enfin, existe un art, un art suprême, dont tous les arts les plus vantés ne sont que les instruments et l'ouvrage : l'art de la raison, le raisonnement 1. ॥ apoio do espírito que conclui ou, melhor ainda, o fruto de um raciocínio preciso, aplicado à interpretação dos fatos. Disso resulta que é possível adquirir experiência sem fazer experiências simplesmente porque se estabelece um raciocínio apropriado sobre os fatos bem estabelecidos; do mesmo modo, é possível fazer experiências e observações sem adquirir experiência se se limita à constatação dos fatos.

A observação é, portanto, o que mostra os fatos; a experiência é o que instrui ${ }^{69}$ os fatos e o que confere experiência em relação a uma coisa. Mas como essa instrução não pode vir senão por uma comparação e uma avaliação, ou seja, após um raciocínio, disso resulta que só o homem é capaz de adquirir experiência e de se aperfeiçoar por meio dela.

"A experiência, diz Goethe, corrige o homem todo dia ". Mas é porque ele raciocina precisa e experimentalmente sobre o que ele observa; sem isso, ele não se corrigiria. O homem que perdeu a razão, o alienado, não se instrui mais pela experiência, ele não raciocina mais experimentalmente. A experiência é, portanto, o privilégio da razão. "Cabe somente ao homem verificar seus pensamentos, ordená-los; cabe somente ao homem corrigir, retificar, melhorar, aperfeiçoar e poder, assim, tornar-se mais hábil, mais sábio e mais feliz todos os dias. Apenas para o homem, finalmente, existe uma arte, uma arte suprema, da qual todas as artes mais aclamadas não são senão os

${ }^{69}$ N.T. Instruire v.t. instruir, ensinar, formar, informar, educar. Cf nota 32, a fim de manter a uniformidade dos termos, da mesma forma que fez o autor, mantivemos, tanto na nominal instruction, como na forma verbal instruire, os termos correspondentes instrução e instruir. 


\begin{tabular}{|c|c|}
\hline & $\begin{array}{l}\text { instrumentos e a obra: a arte da razão, o } \\
\text { raciocínio". } 70\end{array}$ \\
\hline $\begin{array}{l}\text { Nous donnerons au mot expérience, en } \\
\text { médecine expérimentale, le même sens } \\
\text { général qu'il conserve partout. Le savant } \\
\text { s'instruit chaque jour par l'expérience; par } \\
\text { elle il corrige incessamment ses idées } \\
\text { scientifiques, ses théories, les rectifie pour } \\
\text { les mettre en harmonie avec un nombre de } \\
\text { faits de plus en plus grands, et pour } \\
\text { approcher ainsi de plus en plus de la vérité. }\end{array}$ & $\begin{array}{l}\text { Daremos à palavra experiência, em medicina } \\
\text { experimental, o mesmo sentido geral que } \\
\text { ela tem em qualquer lugar. O estudioso } \\
\text { instrui-se todo dia pela experiência; por ela } \\
\text { ele corrige incessantemente suas ideias } \\
\text { científicas, suas teorias, as retifica para } \\
\text { colocá-las em harmonia com um número de } \\
\text { fatos cada vez maior e para, assim, } \\
\text { aproximar-se cada vez mais da verdade. }\end{array}$ \\
\hline $\begin{array}{l}\text { On peut s'instruire, c'est-à-dire acquérir de } \\
\text { l'expérience sur ce qui nous entoure, de } \\
\text { deux manières, empiriquement et } \\
\text { expérimentalement. Il y a d'abord une sorte } \\
\text { d'instruction ou d'expérience inconsciente } \\
\text { et empirique, que l'on obtient par la } \\
\text { pratique de chaque chose. Mais cette } \\
\text { connaissance que l'on acquiert ainsi n'en est } \\
\text { pas moins nécessairement accompagnée } \\
\text { d'un raisonnement expérimental vague que } \\
\text { l'on se fait sans s'en rendre compte, et par } \\
\text { suite duquel on rapproche les faits afin de } \\
\text { porter sur eux un jugement. L'expérience } \\
\text { peut donc s'acquérir par un raisonnement } \\
\text { empirique et inconscient ; mais cette } \\
\text { marche obscure et spontanée de l'esprit a } \\
\text { été érigée par le savant en une méthode } \\
\text { claire et raisonnée, qui procède alors plus } \\
\text { rapidement et d'une manière consciente } \\
\text { vers un but déterminé. Telle est la méthode } \\
\text { expérimentale dans les sciences, d'après } \\
\text { laquelle l'expérience est toujours acquise en } \\
\text { vertu d'un raisonnement précis établi sur } \\
\text { une idée qu'a fait naître l'observation et que } \\
\text { contrôle l'expérience. En effet, il y a dans } \\
\text { toute connaissance expérimentale trois } \\
\text { phases : observation faite, comparaison } \\
\text { établie et jugement motivé. La méthode }\end{array}$ & $\begin{array}{l}\text { É possível instruir-se, isto é, adquirir } \\
\text { experiência sobre o que nos rodeia de duas } \\
\text { maneiras, empírica e experimentalmente. } \\
\text { Há, em primeiro lugar, um tipo de instrução } \\
\text { ou de experiência inconsciente e empírica } \\
\text { que se obtém pela prática de cada coisa. Mas } \\
\text { este conhecimento assim adquirido não é } \\
\text { necessariamente menos vinculado a um } \\
\text { raciocínio experimental vago feito sem } \\
\text { querer e em razão do qual reúnem-se os } \\
\text { fatos a fim de avaliá-los. A experiência pode, } \\
\text { portanto, ser adquirida por um raciocínio } \\
\text { empírico e inconsciente; mas este percurso } \\
\text { obscuro e espontâneo do espírito foi erigido } \\
\text { pelo estudioso num método claro e } \\
\text { refletido, que então opera mais } \\
\text { rapidamente e de forma consciente em } \\
\text { direção a um objetivo determinado. Tal é o } \\
\text { método experimental nas ciências, segundo } \\
\text { o qual a experiência é sempre adquirida em } \\
\text { virtude de um raciocínio preciso, } \\
\text { estabelecido a partir de uma ideia que } \\
\text { nasceu da observação e que a experiência } \\
\text { controla. De fato, há em todo conhecimento } \\
\text { experimental três fases: observação feita, } \\
\text { comparação estabelecida e avaliação } \\
\text { motivada. O método experimental não faz } \\
\text { outra coisa senão propor uma avaliação dos }\end{array}$ \\
\hline
\end{tabular}

${ }^{70}$ LAROMIGUIÈRE, Discours sur I'identité. CEuvres, t. I, p. 329. 
expérimentale ne fait pas autre chose que porter un jugement sur les faits qui nous entourent, à l'aide d'un criterium qui n'est lui-même qu'un autre fait disposé de façon à contrôler le jugement et à donner l'expérience. Prise dans ce sens général, l'expérience est l'unique source des connaissances humaines. L'esprit n'a en luimême que le sentiment d'une relation nécessaire dans les choses, mais il ne peut connaître la forme de cette relation que par l'expérience.

Il y aura donc deux choses à considérer dans la méthode expérimentale : 1ㅇ l'art d'obtenir des faits exacts au moyen d'une investigation rigoureuse; 2 o l'art de les mettre en œuvre au moyen d'un raisonnement expérimental afin d'en faire ressortir la connaissance de la loi des phénomènes. Nous avons dit que le raisonnement expérimental s'exerce toujours et nécessairement sur deux faits à la fois, l'un qui lui sert de point de départ : l'observation; l'autre qui lui sert de conclusion ou de contrôle : l'expérience. Toutefois ce n'est, en quelque sorte, que comme abstraction logique et en raison de la place qu'ils occupent qu'on peut distinguer, dans le raisonnement, le fait observation du fait expérience.

Mais, en dehors du raisonnement expérimental, l'observation et l'expérience n'existent plus dans le sens abstrait qui précède ; il n'y a dans l'une comme dans l'autre que des faits concrets qu'il s'agit d'obtenir par des procédés d'investigation exacts et rigoureux. Nous verrons plus loin que l'investigateur doit être lui-même distingué en observateur et en fatos que nos rodeiam, com o auxílio de um criterium que nada mais é do que outro fato disposto de modo a controlar a avaliação e a proporcionar a experiência. Tomada nesse sentido geral, a experiência é a única fonte dos conhecimentos humanos. O espírito não traz em si mesmo senão o sentimento de uma relação necessária nas coisas, no entanto, ele só pode conhecer a forma dessa relação pela experiência.

Haverá, portanto, duas coisas a considerar no método experimental: 1으 a arte de obter fatos exatos por meio de uma investigação rigorosa; 2ㅇ a arte de executá-los por meio de um raciocínio experimental, a fim de retirar dos mesmos o conhecimento da lei dos fenômenos ${ }^{71}$. Dissemos que o raciocínio experimental se exerce sempre e necessariamente sobre dois fatos ao mesmo tempo, um que lhe serve de ponto de partida: a observação; e outro que the serve de conclusão ou de controle: a experiência. Todavia isso não acontece, de algum modo, senão como abstração lógica, e é em razão do lugar que ocupam que se pode distinguir, no raciocínio, o fato observação do fato experiência.

Mas, fora do raciocínio experimental, a observação e a experiência não existem mais no sentido abstrato precedente; há tanto numa como na outra apenas fatos concretos a serem obtidos por procedimentos de investigação exatos e rigorosos. Veremos mais adiante que o próprio investigador deve ser distinguido em observador e experimentador; não dependendo para isso

\footnotetext{
${ }^{71}$ N.T. Claude Bernard continua preparando o terreno para introduzir a ideia do Determinismo, segundo a qual é possível identificar leis em ciências biológicas ou ciências da vida da mesma forma que na física ou na química.
} 
expérimentateur ; non suivant qu'il est actif ou passif dans la production des phénomènes, mais suivant qu'il agit ou nonsur eux pour s'en rendre maître. que ele seja ativo ou passivo na produção dos fenômenos, mas sim que ele atue ou não sobre eles para dominá-los.

\begin{tabular}{|l|}
\hline III \\
De l'investigateur ; \\
de la recherche scientifique
\end{tabular}

L'art de l'investigation scientifique est la pierre angulaire de toutes les sciences expérimentales. Si les faits qui servent de base au raisonnement sont mal établis ou erronés, tout s'écroulera ou tout deviendra faux ; et c'est ainsi que, le plus souvent, les erreurs dans les théories scientifiques ont pour origine des erreurs de faits.

Dans l'investigation considérée comme art de recherches expérimentales, il n'y a que des faits mis en lumière par l'investigateur et constatés le plus rigoureusement possible, à l'aide des moyens les mieux appropriés. II n'y a plus lieu de distinguer ici l'observateur de l'expérimentateur par la nature des procédés de recherches mis en usage. J'ai montré dans le paragraphe précédent que les définitions et les distinctions qu'on a essayé d'établir d'après l'activité ou la passivité de l'investigation, ne sont pas soutenables. En effet, l'observateur et l'expérimentateur sont des investigateurs qui cherchent à constater les faits de leur mieux et qui emploient à cet effet des moyens d'étude plus ou moins compliqués, selon la complexité des phénomènes qu'ils étudient. Ils peuvent, l'un et l'autre, avoir besoin de la même activité manuelle et intellectuelle, de la même habileté, du même esprit d'invention, pour créer et perfectionner les divers appareils ou instruments d'investigation qui leur sont

\section{III}

\section{Do investigador;} da pesquisa científica

A arte da investigação científica é a pedra angular de todas as ciências experimentais. Se os fatos que servem de base ao raciocínio são mal estabelecidos ou errôneos, tudo desmoronará ou tudo se tornará falso; e é assim que, frequentemente, os erros nas teorias científicas têm como origem erros de fatos.

$\mathrm{Na}$ investigação considerada como arte de pesquisas experimentais, não há senão fatos trazidos à luz pelo investigador e constatados, o mais rigorosamente possível, com o auxílio dos meios mais apropriados. Não há mais como distinguir aqui o observador do experimentador pela natureza dos procedimentos de pesquisa utilizados. Eu mostrei no parágrafo precedente que as definições e as distinções que se tentou estabelecer segundo a atividade ou a passividade da investigação não são sustentáveis. $\mathrm{Na}$ verdade, o observador e o experimentador são investigadores que procuram constatar os fatos da melhor maneira possível e que empregam, para tanto, meios de estudo mais ou menos complicados, de acordo com a complexidade dos fenômenos que eles estudam. Eles podem, tanto um como o outro, precisar da mesma atividade manual e intelectual, da mesma habilidade, do mesmo espírito de invenção para criar e aperfeiçoar os diversos aparelhos ou 
communs pour la plupart. Chaque science a en quelque sorte un genre d'investigation qui lui est propre et un attirail d'instruments et de procédés spéciaux. Cela se conçoit d'ailleurs puisque chaque science se distingue par la nature de ses problèmes et par la diversité des phénomènes qu'elle étudie. L'investigation médicale est la plus compliquée de toutes; elle comprend tous les procédés qui sont propres aux recherches anatomiques, physiologiques, pathologiques et thérapeutiques, et, de plus, en se développant, elle emprunte à la chimie et à la physique une foule de moyens de recherches qui deviennent pour elle de puissants auxiliaires. Tous les progrès des sciences expérimentales se mesurent par le perfectionnement de leurs moyens d'investigation. Tout l'avenir de la médecine expérimentale est subordonné à la création d'une méthode de recherche applicable avec fruit à l'étude des phénomènes de la vie, soit à l'état normal, soit à l'état pathologique. Je n'insisterai pas ici sur la nécessité d'une telle méthode d'investigation expérimentale en médecine, et je n'essayerai pas même d'en énumérer les difficultés. Je me bornerai à dire que toute ma vie scientifique est vouée à concourir pour ma part à cette œuvre immense que la science moderne aura la gloire d'avoir comprise et le mérite d'avoir inaugurée, en laissant aux siècles futurs le soin de la continuer et de la fonder définitivement. Les deux volumes qui constitueront mon ouvrage sur les Principes de la médecine expérimentale seront uniquement consacrés au développement de procédés d'investigation expérimentale appliqués à la physiologie, à la pathologie et instrumentos de investigação que Ihes são comuns em sua maioria. Cada ciência tem, de alguma forma, um gênero de investigação que lhe é próprio e um arsenal de instrumentos e de procedimentos especiais. Isso se dá, aliás, pelo fato de que cada ciência se distingue pela natureza de seus problemas e pela diversidade dos fenômenos que ela estuda. A investigação médica é a mais complicada de todas; ela compreende todos os procedimentos que são próprios às pesquisas anatômicas, fisiológicas, patológicas e terapêuticas e, além disso, ao desenvolver-se, empresta da química e da física um grande número de meios de pesquisa que se tornam para ela poderosos auxiliares. Todos os progressos das ciências experimentais se medem pelo aperfeiçoamento de seus meios de investigação. Todo o porvir da medicina experimental está subordinado à criação de um método de pesquisa aplicável com proveito para o estudo dos fenômenos da vida, seja no estado normal, seja no estado patológico. Não insistirei aqui na necessidade de um tal método de investigação experimental em medicina e também não tentarei enumerar suas dificuldades. Eu me limitarei a dizer que toda a minha vida científica é devotada a contribuir, de minha parte, com a imensa obra que a ciência moderna terá a glória de ter compreendido e o mérito de ter inaugurado, deixando aos séculos vindouros o cuidado de continuá-la e de fundá-la definitivamente. Os dois volumes que constituirão minha obra sobre os Principes de la médecine expérimentale (Princípios da medicina experimental) ${ }^{72}$ serão unicamente consagrados ao desenvolvimento de

\footnotetext{
72 N.T. Como vimos no capítulo 1 deste trabalho, Claude Bernard nunca conseguiu levar a cabo esse projeto. Essa coleção, da qual este texto seria apenas a introdução, nunca chegou a ser escrita, tendo sido interrompida pelo agravamento de uma doença que levou à morte do autor.
} 


\begin{abstract}
à la thérapeutique. Mais comme il est impossible à un seul d'envisager toutes les faces de l'investigation médicale, et pour me limiter encore dans un sujet aussi vaste, je m'occuperai plus particulièrement de la régularisation des procédés de vivisections zoologiques. Cette branche de l'investigation biologique est sans contredit la plus délicate et la plus difficile; mais je la considère comme la plus féconde et comme étant celle qui peut être d'une plus grande utilité immédiate à l'avancement de la médecine expérimentale.
\end{abstract}

Dans l'investigation scientifique, les moindres procédés sont de la plus haute importance. Le choix heureux d'un animal, un instrument construit d'une

certaine façon, l'emploi d'un réactif au lieu d'un autre, suffisent souvent pour résoudre les questions générales les plus élevées. Chaque fois qu'un moyen nouveau et sûr d'analyse expérimentale surgit, on voit toujours la science faire des progrès dans les questions auxquelles ce moyen peut être appliqué. Par contre, une mauvaise méthode et des procédés de recherche défectueux peuvent entraîner dans les erreurs les plus graves et retarder la science en la fourvoyant. En un mot, les plus grandes vérités scientifiques ont leurs racines dans les détails de l'investigation expérimentale qui constituent en quelque sorte le sol dans lequel ces vérités se développent.

Il faut avoir été élevé et avoir vécu dans les laboratoires pour bien sentir toute l'importance de tous ces détails de procédés d'investigation, qui sont si souvent ignorés et méprisés par les faux savants qui s'intitulent généralisateurs. Pourtant on n'arrivera jamais à des généralisations vraiment fécondes et lumineuses sur les procedimentos de investigação experimental aplicados à fisiologia, à patologia e à terapêutica. Mas, como é impossível que uma só pessoa possa considerar todas as faces da investigação médica, e para me limitar ainda a um assunto tão vasto, eu me ocuparei mais particularmente da regularização dos procedimentos de vivissecções zoológicas. Este ramo da investigação biológica é sem dúvida o mais delicado e o mais difícil; mas eu o considero o mais fecundo e aquele que pode ser de uma maior utilidade imediata para o avanço da medicina experimental.

$\mathrm{Na}$ investigação científica, os menores procedimentos são da maior importância. A escolha feliz de um animal, um instrumento construído de uma certa maneira, o emprego de um reagente em lugar de outro frequentemente basta para resolver as questões gerais mais elevadas. Cada vez que um meio novo e preciso de análise experimental surge, sempre se testemunha a ciência fazendo progressos nas questões às quais esse meio pode ser aplicado. Em contrapartida, um método ruim e procedimentos de pesquisa defeituosos podem acarretar erros dos mais graves e retardar a ciência, desviando-a do bom caminho. Em uma palavra, as maiores verdades científicas têm suas raízes nos detalhes da investigação experimental que constituem, de certa forma, o terreno no qual essas verdades se desenvolvem.

É preciso ter sido criado e ter vivido nos laboratórios para sentir bem toda a importância de todos esses detalhes de procedimentos de investigação, que são tão frequentemente ignorados e desprezados pelos falsos estudiosos que se intitulam generalizadores. No entanto, não se chegará jamais a generalizações realmente fecundas 
phénomènes vitaux, qu'autant qu'on aura expérimenté soi-même et remué dans I'hôpital, l'amphithéâtre ou le laboratoire, le terrain fétide ou palpitant de la vie. On a dit quelque part que la vraie science devait être comparée à un plateau fleuri et délicieux sur lequel on ne pouvait arriver qu'après avoir gravi des pentes escarpées et s'être écorché les jambes à travers les ronces et les broussailles. S'il fallait donner une comparaison qui exprimât mon sentiment sur la science de la vie, je dirais que c'est un salon superbe tout resplendissant de lumière, dans lequel on ne peut parvenir qu'en passant par une longue et affreuse cuisine. e esclarecedoras sobre os fenômenos vitais enquanto não se tiver experimentado por si mesmo e revolvido no hospital, no anfiteatro ou no laboratório o solo fétido ou palpitante da vida. Foi dito em algum lugar que a verdadeira ciência devia ser comparada a um planalto florido e agradável ao qual só se pode chegar após terem sido escaladas as encostas escarpadas e ter esfolado as pernas entre os arbustos e os espinhos. Se fosse necessário fazer uma comparação que exprimisse meu sentimento sobre a ciência da vida, eu diria que é um salão soberbo, todo resplandecente de luz, no qual só se pode chegar passando por uma longa e pavorosa cozinha.

\section{IV \\ De l'observateur et de l'expérimentateur ; des sciences d'observation et d'expérimentation}

Nous venons de voir, qu'au point de vue de l'art de l'investigation, l'observation et l'expérience ne doivent être considérées que comme des faits mis en lumière par l'investigateur, et nous avons ajouté que la méthode d'investigation ne distingue pas celui qui observe de celui qui expérimente. Où donc se trouve dès lors, demandera-ton, la distinction entre l'observateur et l'expérimentateur? La voici : on donne le nom d'observateur à celui qui applique les procédés d'investigation simples ou complexes à l'étude de phénomènes qu'il ne fait pas varier et qu'il recueille, par conséquent, tels que la nature les lui offre. On donne le nom d'expérimentateur à celui qui emploie les procédés d'investigation simples ou complexes pour faire varier ou modifier, dans un but quelconque, les

\section{IV}

Do observador e do experimentador; das ciências de observação e de experimentação

Acabamos de ver que, do ponto de vista da arte da investigação, a observação e a experiência devem ser consideradas apenas como fatos trazidos à luz pelo investigador, e nós acrescentamos que o método de investigação não distingue aquele que observa daquele que experimenta. Onde se encontra, então, poder-se-ia perguntar, a distinção entre o observador e o experimentador? Aqui está ela: dá-se o nome de observador àquele que aplica os procedimentos de investigação simples ou complexos ao estudo de fenômenos que ele não faz variar e que ele recolhe, consequentemente, tal como lhe são oferecidos pela natureza. Dá-se o nome de experimentador àquele que emprega os procedimentos de investigação simples ou complexos para fazer variar ou modificar, 
phénomènes naturels et les faire apparaître dans des circonstances ou dans des conditions dans lesquelles la nature ne les lui présentait pas. Dans ce sens, l'observation est l'investigation d'un phénomène naturel, et l'expérience est l'investigation d'un phénomène modifié par l'investigateur. Cette distinction qui semble être tout extrinsèque et résider simplement dans une définition de mots, donne cependant, comme nous allons le voir, le seul sens suivant lequel il faut comprendre la différence importante qui sépare les sciences d'observation des sciences d'expérimentation ou expérimentales. com um objetivo qualquer, os fenômenos naturais e fazê-los aparecer em circunstâncias ou em condições nas quais a natureza não os apresentava. Neste sentido, a observação é a investigação de um fenômeno natural e a experiência é a investigação de um fenômeno modificado pelo investigador. Essa distinção, que parece ser completamente extrínseca e residir simplesmente numa definição de palavras, dá, no entanto, como veremos, o único sentido segundo o qual é necessário compreender a importante diferença que separa as ciências de observação das ciências de experimentação ou experimentais.

Dissemos, num parágrafo precedente, que sob o ponto de vista do raciocínio experimental as palavras observação e experiência, tomadas num sentido abstrato, significam, respectivamente, a constatação pura e simples de um fato e o controle de uma ideia por um fato. Mas, se considerássemos a observação apenas no sentido abstrato, não nos seria possível tirar dela uma ciência da observação. A simples constatação dos fatos jamais poderá chegar a constituir uma ciência. Por mais que se multiplicassem os fatos ou as observações, isto não nos ensinaria mais a seu respeito. Para se instruir, é preciso necessariamente raciocinar sobre o que se observou, comparar os fatos e avaliá-los por outros fatos que servem de controle. Mas uma observação pode servir de controle a uma outra observação. De modo que uma ciência da observação será simplesmente uma ciência feita com observações, ou seja, uma ciência na qual se raciocinará sobre os fatos de observação natural, tal como os definimos mais acima. Uma ciência experimental ou de experimentação será 
expérimentale ou d'expérimentation sera une science faite avec des expériences, c'est-à-dire dans laquelle on raisonnera sur des faits d'expérimentation obtenus dans des conditions que l'expérimentateur a créées et déterminées lui-même.

Il y a des sciences qui, comme l'astronomie, resteront toujours pour nous des sciences d'observation, parce que les phénomènes qu'elles étudient sont hors de notre sphère d'action; mais les sciences terrestres peuvent être à la fois des sciences d'observation et des sciences expérimentales. II faut ajouter que toutes ces sciences commencent par être des sciences d'observation pure ; ce n'est qu'en avançant dans l'analyse des phénomènes qu'elles deviennent expérimentales, parce que l'observateur, se transformant en expérimentateur, imagine des procédés d'investigation pour pénétrer dans les corps et faire varier les conditions des phénomènes. L'expérimentation n'est que la mise en œuvre des procédés d'investigation qui sont spéciaux à l'expérimentateur.

Maintenant, quant au raisonnement expérimental, il sera absolument le même dans les sciences d'observation et dans les sciences expérimentales. II y aura toujours jugement par une comparaison s'appuyant sur deux faits, l'un qui sert de point de départ, l'autre qui sert de conclusion au raisonnement. Seulement dans les sciences d'observation les deux faits seront toujours des observations; tandis que dans les sciences expérimentales les deux faits pourront être empruntés à l'expérimentation exclusivement, ou à l'expérimentation et à l'observation à la fois, selon les cas et suivant que l'on pénètre plus ou moins profondément dans l'analyse expérimentale. Un médecin qui observe une uma ciência feita com experiências, ou seja, na qual se raciocinará sobre fatos de experimentação obtidos em condições que o próprio experimentador criou e determinou.

Existem ciências, como a astronomia, que sempre serão para nós ciências de observação, porque os fenômenos que elas estudam estão fora de nossa esfera de ação; mas as ciências terrestres podem ser tanto ciências de observação quanto ciências experimentais. É preciso acrescentar que todas essas ciências começam sendo ciências de observação pura; é apenas avançando na análise dos fenômenos que elas se tornam experimentais porque o observador, ao se transformar em experimentador, imagina procedimentos de investigação para penetrar nos corpos e fazer variar as condições dos fenômenos. A experimentação é apenas colocar em prática procedimentos de investigação que são especiais para o experimentador.

Agora, quanto ao raciocínio experimental, ele será absolutamente o mesmo nas ciências de observação e nas ciências experimentais. Sempre haverá avaliação por uma comparação apoiada em dois fatos, um que serve de ponto de partida e outro que serve de conclusão para o raciocínio. Somente nas ciências de observação os dois fatos serão sempre observações; ao passo que, nas ciências experimentais, os dois fatos poderão ser emprestados exclusivamente à experimentação ou tanto à experimentação quanto à observação, conforme o caso e dependendo do nível de adentramento mais ou menos profundo na análise experimental. Um médico que observa uma doença em diversas 


\begin{tabular}{|c|c|}
\hline $\begin{array}{l}\text { maladie dans diverses circonstances, qui } \\
\text { raisonne sur l'influence de ces } \\
\text { circonstances, et qui en tire des } \\
\text { conséquences qui se trouvent contrôlées } \\
\text { par d'autres observations; ce médecin fera } \\
\text { un raisonnement expérimental quoiqu'il ne } \\
\text { fasse pas d'expériences. Mais s'il veut aller } \\
\text { plus loin et connaître le mécanisme intérieur } \\
\text { de la maladie, il aura affaire à des } \\
\text { phénomènes cachés, alors il devra } \\
\text { expérimenter; mais il raisonnera toujours } \\
\text { de même. }\end{array}$ & $\begin{array}{l}\text { circunstâncias, que raciocina sobre a } \\
\text { influência dessas circunstâncias e que tira } \\
\text { delas consequências que se encontram } \\
\text { controladas por outras observações, esse } \\
\text { médico fará um raciocínio experimental, } \\
\text { ainda que não faça experiências. Mas, se ele } \\
\text { quiser ir além e conhecer o mecanismo } \\
\text { interior da doença, ele terá que lidar com } \\
\text { fenômenos escondidos, então ele deverá } \\
\text { experimentar; mas, ainda assim, ele terá, } \\
\text { como sempre, de raciocinar. }\end{array}$ \\
\hline $\begin{array}{l}\text { Un naturaliste qui observe des animaux } \\
\text { dans toutes les conditions de leur existence } \\
\text { et qui tire de ces observations des } \\
\text { conséquences qui se trouvent } \\
\text { vérifiées et contrôlées par d'autres } \\
\text { observations, ce naturaliste emploiera la } \\
\text { méthode expérimentale, quoiqu'il ne fasse } \\
\text { pas de l'expérimentation proprement dite. } \\
\text { Mais s'il lui faut aller observer des } \\
\text { phénomènes dans l'estomac, Il doit } \\
\text { imaginer des procédés d'expérimentation } \\
\text { plus ou moins complexes pour voir dans une } \\
\text { cavité cachée à ses regards. Néanmoins le } \\
\text { raisonnement expérimental est toujours le } \\
\text { même; Réaumur et Spallanzani appliquent } \\
\text { également la méthode expérimentale } \\
\text { quand ils font leurs observations d'histoire } \\
\text { naturelle ou leurs expériences sur la } \\
\text { digestion. Quand Pascal fit une observation } \\
\text { barométrique au bas de la tour Saint- } \\
\text { Jacques et qu'il en institua ensuite une autre }\end{array}$ & $\begin{array}{l}\text { Um naturalista que observa animais em } \\
\text { todas as condições de sua existência e que } \\
\text { tira dessas observações consequências que } \\
\text { são verificadas e controladas por outras } \\
\text { observações, esse naturalista empregará o } \\
\text { método experimental, ainda que ele não } \\
\text { faça experimentação propriamente dita. } \\
\text { Mas, se lhe for preciso observar fenômenos } \\
\text { no estômago, ele precisa imaginar } \\
\text { procedimentos de experimentação mais ou } \\
\text { menos complexos para ver numa cavidade } \\
\text { escondida a seu olhar. No entanto, o } \\
\text { raciocínio experimental é sempre o mesmo; } \\
\text { Réaumur }{ }^{73} \text { e Spallanzani }{ }^{74} \text { também aplicam } \\
\text { o método experimental quando eles fazem } \\
\text { suas observações de história natural ou suas } \\
\text { experiências sobre a digestão. Quando } \\
\text { Pascal }{ }^{75} \text { fez uma observação barométrica na } \\
\text { base da torre Saint-Jacques e instituiu em } \\
\text { seguida uma outra no alto da torre, admite- } \\
\text { se que ele fez uma experiência; entretanto, }\end{array}$ \\
\hline
\end{tabular}

\footnotetext{
${ }^{73}$ N.T. REAUMUR, Sieur de René Anthony Farchault, naturalista francês nascido em 1863 . Publicou seis volumes a respeito dos insetos, desenvolveu o termômetro a álcool, com a escala de Réaumur, estudou a digestão química no estômago, entre outros importantes trabalhos científicos em diferentes áreas.

Disponível em: http://todayinsci.com/R/Reaumur Rene/ReaumurRene-Bio.htm

${ }^{74}$ N.T. SPALLANZANI, Lazzaro, cientista italiano nascido em 1729. Fez experimentos que ajudaram a derrubar a teoria da "geração espontânea" ou abiogênese, preparando o terreno para o fim da polêmica que viria a ser resolvida com os experimentos de Louis Pasteur (PURVES, ORIANS e HELLER, 1995, p. 412 e CURTIS e Barnes, 1989, p.86).

${ }^{75}$ N.T. PASCAL, Blaise: matemático, físico, inventor, filósofo francês, nascido em 1623; contribuiu para o estudo dos fluidos e da pressão atmosférica; criou novos campos de estudo em matemática, inventou a calculadora mecânica, entre muitas outras contribuições ao conhecimento humano. http://www.alalettre.com/pascal-bio.php
} 
sur le haut de la tour, on admet qu'il fit une expérience, et, cependant ce ne sont que deux observations comparées sur la pression de l'air, exécutées en vue de l'idée préconçue que cette pression devait varier suivant les hauteurs. Au contraire, quand Jenner ${ }^{1}$ observait le coucou sur un arbre avec une longue vue afin de ne point l'effaroucher, il faisait une simple observation, parce qu'il ne la comparait pas à une première pour en tirer une conclusion et porter sur elle un jugement. De même un astronome fait d'abord des observations, et ensuite raisonne sur elles pour en tirer un ensemble de notions qu'il contrôle par des observations faites dans des conditions propres à ce but. Or cet astronome raisonne comme les expérimentateurs, parce que l'expérience acquise implique partout jugement et comparaison entre deux faits liés dans l'esprit par une idée.

Toutefois, ainsi que nous l'avons déjà dit, il faut bien distinguer l'astronome du savant qui s'occupe des sciences terrestres, en ce que l'astronome est forcé de se borner à l'observation, ne pouvant pas aller dans le ciel expérimenter sur les planètes. C'est là précisément, dans cette puissance de l'investigateur d'agir sur les phénomènes, que se trouve la différence qui sépare les sciences dites d'expérimentation, des sciences dites d'observation.

Laplace considère que l'astronomie est une science d'observation parce qu'on ne peut qu'observer le mouvement des planètes; on são apenas duas observações comparadas sobre a pressão do ar, executadas considerando a ideia preconcebida de que essa pressão devia variar de acordo com a altura. Ao contrário, quando Jenner ${ }^{76}$ ${ }^{77}$ observava de longe o cuco numa árvore para não o assustar, ele fazia uma simples observação, porque ele não a comparava com uma primeira observação para tirar daí uma conclusão e aplicar a isso uma avaliação. Da mesma forma, um astrônomo faz primeiramente observações e, em seguida, raciocina sobre elas para tirar daí um conjunto de noções que ele controla por observações feitas em condições próprias com essa finalidade. Logo, esse astrônomo raciocina como os experimentadores, porque a experiência adquirida implica sempre avaliação e comparação entre dois fatos ligados no espírito por uma ideia.

Todavia, assim como já dissemos anteriormente, é preciso distinguir o astrônomo do estudioso que se ocupa das ciências terrestres, pois o astrônomo é forçado a se limitar à observação, não podendo ir ao céu realizar experiências sobre os planetas. É precisamente nisso, nesse poder do investigador de agir sobre os fenômenos, que está a diferença que separa as ciências ditas de experimentação das ciências ditas de observação.

Laplace $^{78}$ considera que a astronomia é uma ciência de observação porque se pode apenas observar o movimento dos planetas;

\footnotetext{
${ }^{76}$ N.T. JENNER, Edward: médico inglês, nascido em 1749, a quem se atribui a descoberta da vacina contra a varíola em 1796; a partir de observações feitas no campo, percebeu que as ordenhadoras de leite contraíam uma forma branda de varíola e que se tornavam resistentes à varíola humana (CAMPBELL, 1996, p.333).

77 Jenner, E. On the natural history of the Cuckoo. Philosophical Transactions, 1788, chap.XVI, p. 432.

${ }^{78}$ N.T. LAPLACE, Pierre-Simon de- matemático francês nascido em 1749. Escreveu importantes obras em cálculo, probabilidades e mecânica celeste. http://www.bibmath.net/bios/index.php?action=affiche\&quoi=laplace
} 
ne saurait en effet les atteindre pour modifier leur marche et leur appliquer l'expérimentation. "Sur la terre, dit Laplace, nous faisons varier les phénomènes par des expériences; dans le ciel, nous déterminons avec soin tous ceux que nous offrent les mouvements célestes. "Certains médecins qualifient la médecine de science d'observation, parce qu'ils ont pensé à tort que l'expérimentation ne lui était pas applicable.

$\mathrm{Au}$ fond toutes les sciences raisonnent de même et visent au même but. Toutes veulent arriver à la connaissance de la loi des phénomènes de manière à pouvoir prévoir, faire varier ou maîtriser ces phénomènes. Or, l'astronome prédit les mouvements des astres, il en tire une foule de notions pratiques, mais il ne peut modifier par l'expérimentation les phénomènes célestes comme le font le chimiste et le physicien pour ce qui concerne leur science.

Donc, s'il n'y a pas, au point de vue de la méthode philosophique, de différence essentielle entre les sciences d'observation et les sciences d'expérimentation, il en existe cependant une réelle au point de vue des conséquences pratiques que l'homme peut en tirer, et relativement à la puissance qu'il acquiert par leur moyen. Dans les sciences d'observation, l'homme observe et raisonne expérimentalement, mais il n'expérimente pas; et dans ce sens on pourrait dire qu'une science d'observation est une science passive. Dans les sciences d'expérimentation, l'homme observe, mais de plus il agit sur la matière, en analyse les não se poderia, de fato, alcançá-los para modificar seu deslocamento e aplicar sobre eles a experimentação. "Na Terra, diz Laplace, nós fazemos variar os fenômenos por experiências; no céu, nós determinamos com cuidado tudo aquilo que nos apresentam os movimentos celestes. "79 Certos médicos qualificam a medicina como ciência de observação porque eles pensaram erroneamente que a experimentação não Ihe era aplicável.

No fundo, todas as ciências raciocinam do mesmo modo e visam ao mesmo objetivo. Todas querem chegar ao conhecimento da lei dos fenômenos de maneira a poder prever, fazer variar ou controlar esses fenômenos. Porém, o astrônomo prediz os movimentos dos astros, deles retira uma quantidade enorme de noções práticas, mas ele não pode modificar pela experimentação os fenômenos celestes como fazem o químico e o físico para aquilo que diz respeito à sua ciência.

Assim, se não há, do ponto de vista do método filosófico, diferença essencial entre as ciências de observação e as ciências de experimentação, existe, no entanto, uma diferença real do ponto de vista das consequências práticas que o homem pode obter disso e relativamente ao poder que ele adquire por meio delas. Nas ciências de observação, o homem observa e raciocina experimentalmente, mas ele não experimenta; e, nesse sentido, poder-se-ia dizer que uma ciência de observação é uma ciência passiva. Nas ciências de experimentação, o homem observa, mas, além disso, ele age sobre a matéria, analisa

\footnotetext{
${ }^{79}$ LAPLACE. Système du monde, ch. II.
} 
propriétés et provoque à son profit l'apparition de phénomènes, qui sans doute se passent toujours suivant les lois naturelles, mais dans des conditions que la nature n'avait souvent pas encore réalisées. À l'aide de ces sciences expérimentales actives, I'homme devient un inventeur de phénomènes, un véritable contremaître de la création; et l'on ne saurait, sous ce rapport, assigner de limites à la puissance qu'il peut acquérir sur la nature, par les progrès futurs des sciences expérimentales.

Maintenant reste la question de savoir si la médecine doit demeurer une science d'observation ou devenir une science expérimentale. Sans doute la médecine doit commencer par être une simple observation clinique. Ensuite comme l'organisme forme par lui-même une unité harmonique, un petit monde (microcosme) contenu dans le grand monde (macrocosme), on a pu soutenir que la vie était indivisible et qu'on devait se borner à observer les phénomènes que nous offrent dans leur ensemble les organismes vivants sains et malades, et se contenter de raisonner sur les faits observés. Mais si l'on admet qu'il faille ainsi se limiter et si l'on pose en principe que la médecine n'est qu'une science passive d'observation, le médecin ne devra pas plus toucher au corps humain que l'astronome ne touche aux planètes. Dès lors l'anatomie normale ou pathologique, les vivisections, appliquées à la physiologie, à la pathologie et à la thérapeutique, tout cela est complètement inutile. La médecine ainsi conçue ne peut conduire qu'à l'expectation et à des prescriptions hygiéniques plus ou suas propriedades e provoca, em seu proveito, o aparecimento de fenômenos que talvez ocorram sempre de acordo com as leis naturais, mas em condições que a natureza não tinha ainda realizado o suficiente. Com o auxílio dessas ciências experimentais ativas, o homem torna-se um inventor de fenômenos, um verdadeiro contramestre da criação; e não se poderia, a esse respeito, determinar limites ao poder que ele pode conquistar sobre a natureza, pelos progressos futuros das ciências experimentais.

Agora resta a questão de saber se a medicina deve permanecer uma ciência de observação ou se tornar uma ciência experimental. Talvez a medicina deva começar por ser uma simples observação clínica. Posteriormente, como o organismo constitui por si só uma unidade harmônica, um pequeno mundo (microcosmo) contido no grande mundo (macrocosmo), foi possível afirmar que a vida era indivisível e que se devia limitar a observar os fenômenos que os organismos vivos sadios e doentes nos apresentam em seu conjunto e se contentar em raciocinar sobre os fatos observados. Mas se se admite que é preciso limitar-se dessa forma e se se estabelece em princípio que a medicina é apenas uma ciência passiva de observação, o médico não deverá mais tocar o corpo humano, como o astrônomo não toca os planetas. A partir de então, a anatomia normal ou patológica, as vivissecções aplicadas à fisiologia, à patologia e à terapêutica, tudo isso é completamente inútil. A medicina assim concebida não pode conduzir senão à expectação ${ }^{80}$ e a prescrições higiênicas mais

\footnotetext{
${ }^{80}$ N.T. expectation. S.m. expectação.

Trata-se de um termo usado em Medicina na época em que foi escrito o texto de Claude Bernard e refere-se ao método que consiste em deixar atuar as defesas do organismo e cumprir apenas as medidas de higiene e de
} 


\begin{tabular}{|c|c|}
\hline $\begin{array}{l}\text { moins utiles; mais c'est la négation d'une } \\
\text { médecine active, c'est-à-dire d'une } \\
\text { thérapeutique scientifique et réelle. }\end{array}$ & $\begin{array}{l}\text { ou menos úteis; mas é a negação de uma } \\
\text { medicina ativa, isto é, de uma terapêutica } \\
\text { científica e real. }\end{array}$ \\
\hline $\begin{array}{l}\text { Ce n'est point ici le lieu d'entrer dans } \\
\text { l'examen d'une définition aussi importante } \\
\text { que celle de la médecine expérimentale. Je } \\
\text { me réserve de traiter ailleurs cette question } \\
\text { avec tout le développement nécessaire. Je } \\
\text { me borne-à donner simplement ici mon } \\
\text { opinion, en disant que je pense que la } \\
\text { médecine est destinée à être une science } \\
\text { expérimentale et progressive ; et c'est } \\
\text { précisément par suite de mes convictions à } \\
\text { cet égard que je compose cet ouvrage, dans } \\
\text { le but de contribuer pour ma part à favoriser } \\
\text { le développement de cette médecine } \\
\text { scientifique ou expérimentale. }\end{array}$ & $\begin{array}{l}\text { Não é o caso aqui de entrar no exame de } \\
\text { uma definição tão importante como a da } \\
\text { medicina experimental. Eu me reservo, aliás, } \\
\text { de tratar essa questão depois, com todo o } \\
\text { desenvolvimento necessário. Eu me limito } \\
\text { aqui a dar simplesmente minha opinião, } \\
\text { dizendo que acho que a medicina é } \\
\text { destinada a ser uma ciência experimental e } \\
\text { progressiva; e é precisamente em } \\
\text { consequência de minhas convicções a esse } \\
\text { respeito que eu componho esta obra, com o } \\
\text { objetivo de contribuir para favorecer o } \\
\text { desenvolvimento da medicina científica e } \\
\text { experimental. }\end{array}$ \\
\hline $\begin{array}{l}\text { V } \\
\text { L'expérience n'est au fond } \\
\text { qu'une observation provoquée }\end{array}$ & $\begin{array}{l}\text { V } \\
\text { A experiência é, no fundo, apenas } \\
\text { uma observação provocada. }\end{array}$ \\
\hline $\begin{array}{l}\text { Malgré la différence importante que nous } \\
\text { venons de signaler entre les sciences dites } \\
\text { d'observation et les sciences dites } \\
\text { d'expérimentation, l'observateur et } \\
\text { l'expérimentateur n'en ont pas moins, dans } \\
\text { leurs investigations, pour but commun et } \\
\text { immédiat d'établir et de constater des faits } \\
\text { ou des phénomènes aussi rigoureusement } \\
\text { que possible, et à l'aide des moyens les } \\
\text { mieux appropriés; ils se comportent } \\
\text { absolument comme s'il s'agissait de deux }\end{array}$ & $\begin{array}{l}\text { Apesar da importante diferença que } \\
\text { acabamos de assinalar entre as ciências ditas } \\
\text { de observação e as ciências ditas de } \\
\text { experimentação, o observador e o } \\
\text { experimentador não deixam de ter, em suas } \\
\text { investigações, o objetivo comum e imediato } \\
\text { de estabelecer e constatar fatos ou } \\
\text { fenômenos, o mais rigorosamente possível, } \\
\text { e com o auxílio dos meios mais apropriados; } \\
\text { eles se comportam absolutamente como se } \\
\text { se tratassem de duas observações comuns. }\end{array}$ \\
\hline
\end{tabular}

dietética, quando os sintomas de uma doença não são suficientemente claros para determinar um tratamento (cf. Dicionário Priberam da Língua Portuguesa [em linha], 2008- 2013, http://www.priberam.pt/dlpo/expecta\%C3\%A7\%C3\%A3o [consultado em 08-06-2015].

$\mathrm{Na}$ obra de Claude Bernard, podem ser encontradas referências a esse procedimento em Medicina quando ele afirma: "Quanto à terapêutica, ela é inexistente em Hipócrates, ou ela é, acima de tudo, uma expectação que deixa a natureza agir, porque a observação mostrava que as doenças seriam curadas apenas pelo esforço da natureza. Tem-se ali uma medicina essencialmente científica, como medicina de observação, mas é uma medicina passiva que deixa a natureza agir [...]" (C. Bernard, Princ. med. exp.,1878, p. 96, tradução nossa). 
observations ordinaires. Ce n'est en effet qu'une constatation de fait dans les deux cas ; La seule différence consiste en ce que le fait que doit constater l'expérimentateur ne s'étant pas présenté naturellement à lui, il a dû le faire apparaître, c'est-à-dire le provoquer par une raison particulière et dans un but déterminé. D'où il suit que l'on peut dire : l'expérience n'est au fond qu'une. observation provoquée dans un but quelconque. Dans la méthode expérimentale, la recherche des faits, c'està-dire l'investigation, s'accompagne toujours d'un raisonnement, de sorte que le plus ordinairement l'expérimentateur fait une expérience pour contrôler ou vérifier la valeur d'une idée expérimentale. Alors on peut dire que, dans ce cas, l'expérience est une observation provoquée dans un but de contrôle.

Toutefois il importe de rappeler ici, afin de compléter notre définition et de l'étendre aux sciences d'observation, que, pour contrôler une idée, il n'est pas toujours absolument nécessaire de faire soi-même une expérience ou une observation. On sera seulement forcé de recourir à l'expérimentation, quand l'observation que l'on doit provoquer n'existe pas toute préparée dans la nature. Mais si une observation est déjà réalisée, soit naturellement, soit accidentellement, soit même par les mains d'un autre investigateur, alors on la prendra toute faite et on l'invoquera simplement pour servir de vérification à l'idée expérimentale. Ce qui se résumerait encore en disant que, dans ce cas, l'expérience n'est qu'une observation invoquée dans un but de contrôle. D'où il résulte que, pour raisonner expérimentalement, il faut généralement avoir une idée et invoquer ou provoquer
Nada mais é, na verdade, que uma constatação de fato nos dois casos; a única diferença consiste no fato de o experimentador precisar constatá-lo, uma vez que não lhe foi apresentado naturalmente; ele teve de fazê-lo aparecer, ou seja, provocá-lo por um motivo particular e com um objetivo determinado. Daí podese dizer: a experiência, no fundo, não é senão uma observação provocada com um objetivo qualquer. No método experimental, a busca dos fatos, isto é, a investigação, é sempre acompanhada de um raciocínio, de modo que normalmente o experimentador faz uma experiência para controlar ou verificar o valor de uma ideia experimental. Assim, pode-se dizer, nesse caso, que a experiência é uma observação provocada com um objetivo de controle.

Todavia, é importante lembrar aqui, a fim de completar nossa definição e estendê-la às ciências de observação, que, para controlar uma ideia, nem sempre é absolutamente necessário fazer uma experiência ou uma observação. Será somente obrigatório recorrer à experimentação quando a observação que se deve provocar não existe totalmente pronta na natureza. Mas, se uma observação já foi feita, seja natural ou acidentalmente, ou mesmo pelas mãos de outro investigador, então ela será tomada como pronta e se recorrerá a ela simplesmente para que sirva de verificação à ideia experimental. O que se resumiria ainda dizendo que, neste caso, a experiência não é senão uma observação invocada com um objetivo de controle. Disso resulta que, para raciocinar experimentalmente, geralmente é preciso ter uma ideia e, em seguida, invocar ou produzir fatos, isto é, observações, para controlar essa ideia preconcebida. 


\begin{abstract}
ensuite des faits, c'est-à-dire des observations, pour contrôler cette idée préconçue.
\end{abstract}

Nous examinerons plus loin l'importance de l'idée expérimentale préconçue, qu'il nous suffise de dire dès à présent que l'idée en vertu de laquelle l'expérience est instituée peut être plus ou moins bien définie, suivant la nature du sujet et suivant l'état de perfection de la science dans laquelle se expérimente. En effet, l'idée directrice de l'expérience doit renfermer tout ce qui est déjà connu sur le sujet, afin de guider plus sûrement la recherche vers les problèmes dont la solution peut être féconde pour l'avancement de la science. Dans les sciences constituées, comme la physique et la chimie, l'idée expérimentale se déduit comme une conséquence logique des théories régnantes, et elle est soumise dans un sens bien défini au contrôle de l'expérience ; mais quand il s'agit d'une science dans l'enfance, comme la médecine, où existent des questions complexes ou obscures non encore étudiées, l'idée expérimentale ne se dégage pas toujours d'un sujet aussi vague. Que faut-il faire alors ? Faut-il s'abstenir et attendre que les observations, en se présentant d'ellesmêmes, nous apportent des idées plus claires ? On pourrait souvent attendre longtemps et même en vain ; on gagne toujours à expérimenter. Mais dans ces cas on ne pourra se diriger que d'après une sorte d'intuition, suivant les probabilités que I'on apercevra, et même si le sujet est complètement obscur et inexploré, le physiologiste ne devra pas craindre d'agir même un peu au hasard afin d'essayer, qu'on me permette cette expression vultaire, de pêcher en eau trouble. Ce qui veut dire qu'il peut espérer, au milieu des perturbations fonctionnelles qu'il produira,
Examinaremos mais adiante a importância da ideia experimental preconcebida, bastando dizer neste momento que a ideia em virtude da qual a experiência é instituída pode ser mais ou menos bem definida, de acordo com a natureza do sujeito e segundo o estado de perfeição da ciência na qual se experimenta. De fato, a ideia diretriz da experiência deve conter tudo o que já é conhecido sobre o assunto, a fim de guiar mais seguramente a pesquisa na direção dos problemas cuja solução pode ser fecunda para o avanço da ciência. Nas ciências constituídas, como a física e a química, a ideia experimental se deduz como uma consequência lógica das teorias reinantes, e ela está submetida, num sentido bem definido, ao controle da experiência; mas, quando se trata de uma ciência ainda em seus primeiros passos, como a medicina, em que existem questões complexas ou obscuras, ainda não estudadas, a ideia experimental nunca se desvencilha de um assunto tão vago. O que é preciso fazer, então? É preciso se abster e esperar que as observações, apresentando-se por elas mesmas, nos tragam ideias mais claras? Poder-se-ia, com frequência, esperar por muito tempo e até mesmo em vão; sempre se ganha ao experimentar. Mas, nesses casos, só se poderá guiar por uma espécie de intuição, de acordo com as probabilidades que serão percebidas e, mesmo que o assunto seja completamente obscuro e inexplorado, o fisiologista não deverá ter medo de agir, mesmo que um pouco ao acaso, a fim de tentar, se me permitem esta expressão popular, pescar em águas turvas. Isto quer dizer que ele poderá, em meio a perturbações funcionais que ele produzirá, 
voir surgir quelque phénomène imprévu qui lui donnera une idée sur la direction à imprimer à ses recherches. Ces sortes d'expériences de tâtonnement, qui sont extrêmement fréquentes en physiologie, en pathologie et en thérapeutique, à cause de l'état complexe et arriéré de ces sciences, pourraient être appelées des expériences pour voir. parce qu'elles sont destinées à faire surgir une première observation imprévue et indéterminée d'avance, mais dont l'apparition pourra suggérer une idée expérimentale et ouvrir une voie de recherche.

Comme on le voit, il y a des cas où l'on expérimente sans avoir une idée probable à vérifier. Cependant l'expérimentation, dans ce cas, n'en est pas moins destinée à provoquer une observation, seulement elle la provoque en vue d'y trouver une idée qui lui indiquera la route ultérieure à suivre dans l'investigation. peut donc dire alors que l'expérience est une observation provoquée dans le but de faire naître une idée.

En résumé, l'investigateur cherche et conclut ; il comprend l'observateur et l'expérimentateur ; il poursuit la découverte d'idées nouvelles, en même temps qu'il cherche des faits pour en tirer une conclusion ou une expérience propre à contrôler d'autres idées.

Dans un sens général et abstrait, l'expérimentateur est donc celui qui invoque ou provoque, dans des conditions déterminées, des faits d'observation pour en tirer l'enseignement qu'il désire, c'est-àdire l'expérience. L'observateur est celui qui obtient les faits d'observation et qui juge s'ils sont bien établis et constatés à l'aide de moyens convenables. Sans cela, les ver surgir algum fenômeno imprevisto que Ihe dará uma ideia sobre a direção a conferir às suas pesquisas. Esse tipo de experiência, de tateamento, extremamente frequente em fisiologia, em patologia e em terapêutica, pelo estado complexo e antiquado dessas ciências, poderia ser chamado de experiência para ver, uma vez que são destinadas a fazer surgir uma primeira observação imprevista e não determinada previamente, mas cujo aparecimento poderá sugerir uma ideia experimental e abrir uma via de pesquisa.

Como se pode perceber, há casos em que se experimenta sem se ter uma ideia provável a verificar. No entanto, a experimentação, nesse caso, não deixa de ser destinada a produzir uma observação; só que ela a provoca a fim de encontrar ali uma ideia que Ihe indicará a rota subsequente a seguir na investigação. Pode-se dizer, portanto, que a experiência é uma observação provocada com o intuito de fazer nascer uma ideia.

Resumindo, o investigador pesquisa e conclui; ele compreende o observador e o experimentador; ele busca a descoberta de novas ideias, ao mesmo tempo em que procura fatos para deles tirar uma conclusão ou obter uma experiência adequada para controlar outras ideias.

Num sentido geral e abstrato, o experimentador é, portanto, aquele que invoca ou provoca, em condições determinadas, fatos de observação para deles tirar o ensinamento que deseja, isto é, a experiência. O observador é aquele que obtém os fatos da observação e que avalia se estão bem estabelecidos e constatados com o auxílio de meios convenientes. Sem isso, as 


\begin{abstract}
conclusions basées sur ces faits seraient sans fondement solide. C'est ainsi que l'expérimentateur doit être en même temps bon observateur, et que dans la méthode expérimentale, l'expérience et l'observation marchent toujours de front.

\section{VI \\ Dans le raisonnement expérimental, l'expérimentateur ne se sépare pas de l'observateur.}

conclusões baseadas nesses fatos não teriam fundamento sólido. É assim que, ao mesmo tempo, o experimentador deve ser bom observador e, no método experimental, a experiência e a observação caminham sempre juntas.
Le savant qui veut embrasser l'ensemble des principes de la méthode expérimentale doit remplir deux ordres de conditions et posséder deux qualités de l'esprit qui sont indispensables pour atteindre son but et arriver à la découverte de la vérité. D'abord le savant doit avoir une idée qu'il soumet au contrôle des faits; mais en même temps il doit s'assurer que les faits qui servent de point de départ ou de contrôle à son idée, sont justes et bien établis ; c'est pourquoi il doit être lui-même à la fois observateur et expérimentateur.

L'observateur, avons-nous dit, constate purement et simplement le phénomène qu'il a sous les yeux. II ne doit avoir d'autre souci que de se prémunir contre les erreurs d'observation qui pourraient lui faire voir incomplètement ou mal définir un phénomène. À cet effet, il met en usage tous les instruments qui pourront l'aider à rendre son observation plus complète. L'observateur doit être le photographe des phénomènes, son observation doit représenter exactement la nature. II faut observer sans idée préconçue ; l'esprit de l'observateur doit être passif, c'est-à-dire se

\section{VI}

No raciocínio experimental, o experimentador não se separa do observador.

O estudioso que quer abarcar o conjunto dos princípios do método experimental deve preencher dois tipos de condições e possuir duas qualidades de espírito indispensáveis para alcançar seu objetivo e chegar à descoberta da verdade. Primeiramente, o estudioso deve ter uma ideia que ele submete ao controle dos fatos; mas ao mesmo tempo ele deve se assegurar de que os fatos que servem de ponto de partida ou de controle para a sua ideia sejam precisos e bem estabelecidos; é por isso que ele deve ser ao mesmo tempo observador $\mathrm{e}$ experimentador.

O observador, como dissemos, constata pura e simplesmente o fenômeno que ele tem diante dos olhos. Ele não deve ter outra preocupação senão a de se precaver contra os erros de observação que poderiam lhe fazer ver de forma incompleta ou definir mal um fenômeno. Para isso, ele utiliza todos os instrumentos que poderão ajudá-lo a tornar sua observação mais completa. O observador deve ser o fotógrafo dos fenômenos, sua observação deve representar fielmente a natureza. É preciso observar sem ideia preconcebida; o espírito do observador deve ser passivo, isto é, se 


\begin{tabular}{|c|c|}
\hline $\begin{array}{l}\text { taire ; il écoute la nature et écrit sous sa } \\
\text { dictée. }\end{array}$ & $\begin{array}{l}\text { calar; ele escuta a natureza e escreve o que } \\
\text { ela dita. }\end{array}$ \\
\hline $\begin{array}{l}\text { Mais une fois le fait constaté et le } \\
\text { phénomène bien observé, l'idée arrive, le } \\
\text { raisonnement intervient } \\
\text { l'expérimentateur apparaît pour interpréter } \\
\text { le phénomène. }\end{array}$ & $\begin{array}{l}\text { Mas, uma vez tendo sido constatado o fato e } \\
\text { bem observado o fenômeno, a ideia surge, o } \\
\text { raciocínio intervém e o experimentador } \\
\text { aparece para interpretar o fenômeno. }\end{array}$ \\
\hline $\begin{array}{l}\text { L'expérimentateur, comme nous le savons } \\
\text { déjà, est celui qui, en vertu d'une } \\
\text { interprétation plus ou moins probable, mais } \\
\text { anticipée des phénomènes observés, } \\
\text { institue l'expérience de manière que, dans } \\
\text { l'ordre logique de ses prévisions, elle } \\
\text { fournisse un résultat qui serve de contrôle à } \\
\text { l'hypothèse ou à l'idée préconçue. Pour cela } \\
\text { l'expérimentateur réfléchit, essaye, } \\
\text { tâtonne, compare et combine pour trouver } \\
\text { les conditions expérimentales les plus } \\
\text { propres à atteindre le but qu'il se propose. Il } \\
\text { faut nécessairement expérimenter avec une } \\
\text { idée préconçue. L'esprit de } \\
\text { l'expérimentateur doit être actif, c'est-à- } \\
\text { dire qu'il doit interroger la nature et lui } \\
\text { poser les questions dans tous les sens, } \\
\text { suivant les diverses hypothèses qui lui sont } \\
\text { suggérées. }\end{array}$ & $\begin{array}{l}\text { O experimentador, como já sabemos, é } \\
\text { aquele que, em virtude de uma } \\
\text { interpretação mais ou menos provável, } \\
\text { porém antecipada dos fenômenos } \\
\text { observados, institui a experiência de forma } \\
\text { que, na ordem lógica de suas previsões, ela } \\
\text { forneça um resultado que sirva de controle à } \\
\text { hipótese ou à ideia preconcebida. Para isso, } \\
\text { o experimentador reflete, testa, manipula, } \\
\text { compara e combina, a fim de encontrar as } \\
\text { condições experimentais mais adequadas } \\
\text { para alcançar o objetivo a que se propõe. É } \\
\text { preciso necessariamente experimentar com } \\
\text { uma ideia preconcebida. O espírito do } \\
\text { experimentador deve ser ativo, isto é, ele } \\
\text { deve interrogar a natureza e questioná-la } \\
\text { em todos os sentidos, de acordo com as } \\
\text { diversas hipóteses que lhe são sugeridas. }\end{array}$ \\
\hline $\begin{array}{l}\text { Mais, une fois les conditions de l'expérience } \\
\text { instituées et mises en œuvre d'après l'idée } \\
\text { préconçue ou la vue anticipée de l'esprit, il } \\
\text { va, ainsi que nous l'avons déjà dit, en } \\
\text { résulter une observation provoquée ou } \\
\text { préméditée. II s'ensuit l'apparition de } \\
\text { phénomènes que l'expérimentateur a } \\
\text { déterminés, mais qu'il s'agira de constater } \\
\text { d'abord, afin de savoir ensuite quel contrôle } \\
\text { on pourra en tirer relativement à l'idée } \\
\text { expérimentale qui les a fait naître. }\end{array}$ & $\begin{array}{l}\text { Mas, uma vez as condições da experiência } \\
\text { instituídas e executadas de acordo com a } \\
\text { ideia preconcebida ou a visão antecipada do } \\
\text { espírito, disso resultará, como já dissemos, } \\
\text { uma observação provocada ou premeditada. } \\
\text { Segue-se o aparecimento de fenômenos } \\
\text { determinados pelo experimentador, mas } \\
\text { que deverão ser previamente constatados, a } \\
\text { fim de saber em seguida qual controle se } \\
\text { poderá obter relativamente à ideia } \\
\text { experimental que lhes deu origem. }\end{array}$ \\
\hline $\begin{array}{l}\text { Or, dès le moment où le résultat de } \\
\text { l'expérience se } \\
\text { l'expérimentateur se trouve en face d'une }\end{array}$ & $\begin{array}{l}\text { Logo, a partir do momento em que o } \\
\text { resultado da experiência se manifesta, o } \\
\text { experimentador se encontra diante de uma }\end{array}$ \\
\hline
\end{tabular}


véritable observation qu'il a provoquée, et qu'il faut constater, comme toute observation, sans aucune idée préconçue. L'expérimentateur doit alors disparaître ou plutôt se transformer instantanément en observateur ; et ce n'est qu'après qu'il aura constaté les résultats de l'expérience absolument comme ceux d'une observation ordinaire, que son esprit reviendra pour raisonner, comparer et juger si l'hypothèse expérimentale est vérifiée ou infirmée par ces mêmes résultats. Pour continuer la comparaison énoncée plus haut, je dirai que l'expérimentateur pose des questions à la nature ; mais que, dès qu'elle parle, il doit se taire ; il doit constater ce qu'elle répond, l'écouter jusqu'au bout, et, dans tous les cas, se soumettre à ses décisions. L'expérimentateur doit forcer la nature à se dévoiler, a-t-on dit. Oui, sans doute, l'expérimentateur force la nature à se dévoiler, en l'attaquant et en lui posant des questions dans tous les sens; mais il ne doit jamais répondre pour elle ni écouter incomplètement ses réponses en ne prenant dans l'expérience que la partie des résultats qui favorisent ou confirment l'hypothèse. Nous verrons ultérieurement que c'est là un des plus grands écueils de la méthode expérimentale. L'expérimentateur qui continue à garder son idée préconçue, et qui ne constate les résultats de l'expérience qu'à ce point de vue, tombe nécessairement dans l'erreur, parce qu'il néglige de constater ce qu'il n'avait pas prévu et fait alors une observation incomplète. L'expérimentateur ne doit pas tenir à son idée autrement que comme à un moyen de solliciter une réponse de la nature. Mais il doit soumettre son idée à la nature et être prêt à l'abandonner, à la modifier ou à la changer, suivant ce que l'observation des phénomènes qu'il a provoqués lui enseignera. verdadeira observação que ele provocou, e que é preciso constatar, como toda observação, sem qualquer ideia preconcebida. 0 experimentador deve, então, desaparecer ou, de preferência, transformar-se instantaneamente em observador; e é somente depois que ele terá constatado inteiramente os resultados da experiência, como os de uma observação qualquer, sobre a qual seu espírito voltará a raciocinar, comparar e a qual voltará a avaliar se a hipótese experimental for verificada ou refutada por esses mesmos resultados. Para prosseguir com a comparação feita anteriormente, eu direi que o experimentador faz perguntas à natureza; mas que, a partir do momento em que ela fala, ele deve se calar; ele deve constatar o que ela responde, escutá-la até o fim e, em todos os casos, submeter-se às suas decisões. $O$ experimentador deve forçar a natureza a se desvelar, como foi dito. Sim, talvez, o experimentador force a natureza a se desvelar, atacando-a e questionando-a em todos os sentidos; mas ele não deve jamais responder por ela nem escutar suas respostas de maneira incompleta, tomando apenas da experiência a parte dos resultados que favorecem ou confirmam a hipótese. Nós veremos adiante que aí reside uma das maiores armadilhas do método experimental. O experimentador que conserva sua ideia preconcebida e que só constata os resultados da experiência sob esse ponto de vista cai necessariamente em erro, porque ele deixa de constatar aquilo que ele não havia previsto e faz assim uma observação incompleta. O experimentador não deve se ater à sua ideia senão como um meio de solicitar uma resposta da natureza. Mas ele deve submeter sua ideia à natureza e estar pronto a abandoná-la, a modificá-la ou a transformá-la, de acordo com aquilo 


\begin{tabular}{|c|c|}
\hline & $\begin{array}{l}\text { que a observação dos fenômenos que ele } \\
\text { provocou lhe ensinará. }\end{array}$ \\
\hline $\begin{array}{l}\text { Il y a donc deux opérations à considérer dans } \\
\text { une expérience. La première consiste à } \\
\text { préméditer et à réaliser les conditions de } \\
\text { l'expérience ; la deuxième consiste à } \\
\text { constater les résultats de l'expérience. Il } \\
\text { n'est pas possible d'instituer une expérience } \\
\text { sans une idée préconçue; instituer une } \\
\text { expérience, avons-nous dit, c'est poser une } \\
\text { question; on ne conçoit jamais une question } \\
\text { sans l'idée qui sollicite la réponse. Je } \\
\text { considère donc, en principe absolu, que } \\
\text { l'expérience doit toujours être instituée en } \\
\text { vue d'une idée préconçue, peu importe que } \\
\text { cette idée soit plus ou moins vague, plus ou } \\
\text { moins bien définie. Quant à la constatation } \\
\text { des résultats de l'expérience, qui n'est elle- } \\
\text { même qu'une observation provoquée, je } \\
\text { pose également en principe qu'elle doit être } \\
\text { faite là comme dans toute autre } \\
\text { observation, c'est-à-dire sans idée } \\
\text { préconçue. }\end{array}$ & $\begin{array}{l}\text { Há, portanto, duas operações a considerar } \\
\text { numa experiência. A primeira consiste em } \\
\text { premeditar e realizar as condições da } \\
\text { experiência; a segunda consiste em } \\
\text { constatar os resultados da experiência. Não } \\
\text { é possível instituir uma experiência sem uma } \\
\text { ideia preconcebida; instituir uma } \\
\text { experiência, como dissemos, é fazer uma } \\
\text { pergunta; não se concebe jamais uma } \\
\text { pergunta sem a ideia que pede a resposta. } \\
\text { Eu considero, portanto, como princípio } \\
\text { absoluto, que a experiência deve sempre ser } \\
\text { instituída em vista de uma ideia } \\
\text { preconcebida, pouco importando que essa } \\
\text { ideia seja mais ou menos vaga, mais ou } \\
\text { menos bem definida. Quanto à constatação } \\
\text { dos resultados da experiência, que não é ela } \\
\text { mesma senão uma observação provocada, } \\
\text { eu também coloco como princípio que ela } \\
\text { deve ser feita nesse caso como em qualquer } \\
\text { outra observação, isto é, sem ideia } \\
\text { preconcebida. }\end{array}$ \\
\hline $\begin{array}{l}\text { On pourrait encore distinguer et séparer } \\
\text { dans l'expérimentateur celui qui prémédite } \\
\text { et institue l'expérience de celui qui en } \\
\text { réalise l'exécution ou en constate les } \\
\text { résultats. Dans le premier cas, c'est l'esprit } \\
\text { de l'inventeur scientifique qui agit ; dans le } \\
\text { second, ce sont les sens qui observent ou } \\
\text { constatent. La preuve de ce que j'avance } \\
\text { nous est fournie de la manière la plus } \\
\text { frappante par l'exemple de Fr. Huber }{ }^{1} \text { Ce } \\
\text { grand naturaliste, quoiqu'aveugle, nous a } \\
\text { laissé d'admirables expériences qu'il } \\
\text { concevait et faisait ensuite exécuter par son }\end{array}$ & $\begin{array}{l}\text { Ainda se poderia distinguir e separar no } \\
\text { experimentador aquele que prevê e institui } \\
\text { a experiência daquele que a executa ou } \\
\text { constata seus resultados. No primeiro caso, } \\
\text { é o espírito do inventor científico que age; no } \\
\text { segundo, são os sentidos que observam ou } \\
\text { constatam. A prova do que adianto aqui nos } \\
\text { é fornecida da maneira mais impressionante } \\
\text { pelo exemplo de Fr. Huber } 81 \text {. Este grande } \\
\text { naturalista, ainda que cego, nos deixou } \\
\text { admiráveis experiências que ele concebia e } \\
\text { que eram posteriormente postas em prática } \\
\text { por seu empregado, que não tinha, de sua }\end{array}$ \\
\hline
\end{tabular}

${ }^{81}$ N.T. HUBER, François- Naturalista e escritor suíço nascido em 1750. Embora tenha ficado cego devido a uma doença degenerativa, fez, com a ajuda de sua esposa, importantes estudos sobre as abelhas e a produção do mel e da cera. http://www.encyclo.co.uk/define/Fran\%C3\%A7ois\%2OHuber

${ }^{82}$ HUBER, F. Nouvelles observations sur les Abeilles, 2e édition, augmentée par son fils, Pierre Huber. Genève, 1814. 
domestique, qui n'avait pour sa part aucune idée scientifique. Huber était donc l'esprit directeur qui instituait l'expérience; mais il était obligé d'emprunter les sens d'un autre. Le domestique représentait les sens passifs qui obéissent à l'intelligence pour réaliser l'expérience instituée en vue d'une idée préconçue.

Ceux qui ont condamné l'emploi des hypothèses et des idées préconçues dans la méthode expérimentale ont eu tort de confondre l'invention de l'expérience avec la constatation de ses résultats. II est vrai de dire qu'il faut constater les résultats de l'expérience avec un esprit dépouillé d'hypothèses et d'idées préconçues. Mais il faudrait bien se garder de proscrire l'usage des hypothèses et des idées quand il s'agit d'instituer l'expérience ou d'imaginer des moyens d'observation. On doit, au contraire, comme nous le verrons bientôt, donner libre carrière à son imagination ; c'est l'idée qui est le principe de tout raisonnement et de toute invention, c'est à elle que revient toute espèce d'initiative. On ne saurait l'étouffer ni la chasser sous prétexte qu'elle peut nuire, il ne faut que la régler et lui donner un criterium, ce qui est bien différent.

Le savant complet est celui qui embrasse à la fois la théorie et la pratique expérimentale. 10 II constate un fait ; 20 à propos de ce fait, une idée naît dans son esprit ; 3o en vue de cette idée, il raisonne, institue une expérience, en imagine et en réalise les conditions matérielles. 4으 De cette expérience résultent de nouveaux phénomènes qu'il faut observer, et ainsi de suite. L'esprit du savant se trouve en quelque sorte toujours placé entre deux observations : l'une qui sert de point de parte, nenhum conhecimento científico. Huber era, portanto, o espírito diretor que instituía a experiência; mas ele era obrigado a tomar emprestado os sentidos de um outro. O empregado representava os sentidos passivos que obedecem à inteligência para realizar a experiência instituída em vista de uma ideia preconcebida.

Aqueles que condenaram o emprego das hipóteses e das ideias preconcebidas no método experimental enganaram-se ao confundir a invenção da experiência com a constatação de seus resultados. É certo dizer que é preciso constatar os resultados da experiência com um espírito desprovido de hipóteses e de ideias preconcebidas. Mas seria preciso se precaver de descartar o uso das hipóteses e das ideias quando se trata de instituir a experiência ou de imaginar meios de observação. Deve-se, pelo contrário, como veremos daqui a pouco, deixar o caminho livre para a imaginação; é a ideia que é o princípio de todo raciocínio e de toda invenção, é a ela que retorna todo tipo de iniciativa. Não se poderia abafá-la nem exclui-la sob o pretexto de que ela pode atrapalhar, só é preciso regulá-la e dar- Ihe um critério, o que é bem diferente.

O estudioso completo é aquele que abraça, ao mesmo tempo, a teoria e a prática experimental. 10 Ele constata um fato; $20 \mathrm{a}$ respeito desse fato, uma ideia nasce em seu espírito; 3ㅇ em vista dessa ideia, ele raciocina, institui uma experiência, imagina e realiza suas condições materiais. 4o Dessa experiência resultam novos fenômenos que é preciso observar, e assim por diante. 0 espírito do estudioso se encontra, de certa forma, situado sempre entre duas observações: uma que serve de ponto de 


\begin{tabular}{|c|c|}
\hline $\begin{array}{l}\text { départ au raisonnement, et l'autre qui lui } \\
\text { sert de conclusion. }\end{array}$ & $\begin{array}{l}\text { partida para o raciocínio e outra que lhe } \\
\text { serve de conclusão. }\end{array}$ \\
\hline $\begin{array}{l}\text { Pour être plus clair, je me suis efforcé de } \\
\text { séparer les diverses opérations du } \\
\text { raisonnement expérimental. Mais quand } \\
\text { tout cela se passe à la fois dans la tête d'un } \\
\text { savant qui se livre à l'investigation dans une } \\
\text { science aussi confuse que l'est encore la } \\
\text { médecine, alors il y a un enchevêtrement } \\
\text { tel, entre ce qui résulte de l'observation et } \\
\text { ce qui appartient à l'expérience, qu'il serait } \\
\text { impossible et d'ailleurs inutile de vouloir } \\
\text { analyser dans leur mélange inextricable } \\
\text { chacun de ces termes. Il suffira de retenir en } \\
\text { principe que l'idée a priori ou mieux } \\
\text { l'hypothèse est le stimulus de l'expérience, } \\
\text { et qu'on doit s'y laisser aller librement, } \\
\text { pourvu qu'on observe les résultats de } \\
\text { l'expérience d'une manière rigoureuse et } \\
\text { complète. Si l'hypothèse ne se vérifie pas et } \\
\text { disparaît, les faits qu'elle aura servi à trouver } \\
\text { resteront néanmoins acquis comme des } \\
\text { matériaux inébranlables de la science. }\end{array}$ & $\begin{array}{l}\text { Para ser mais claro, me esforcei em separar } \\
\text { as diversas operações do raciocínio } \\
\text { experimental. Mas quando tudo isso se } \\
\text { passa ao mesmo tempo na cabeça de um } \\
\text { estudioso que se entrega à investigação } \\
\text { numa ciência tão confusa quanto ainda é a } \\
\text { medicina, então há uma tal confusão entre o } \\
\text { que resulta da observação e o que pertence } \\
\text { à experiência que seria impossível e, aliás, } \\
\text { inútil querer analisar em sua mistura } \\
\text { inextricável cada um desses termos. Bastará } \\
\text { reter em princípio que a ideia a priori, ou } \\
\text { melhor, a hipótese é o estímulo da } \\
\text { experiência e que se deve deixar levar } \\
\text { livremente, desde que se observem os } \\
\text { resultados da experiência de uma maneira } \\
\text { rigorosa e completa. Se a hipótese não se } \\
\text { verifica e desaparece, os fatos que ela terá } \\
\text { ajudado a encontrar permanecerão, pelo } \\
\text { menos, adquiridos como materiais } \\
\text { inabaláveis da ciência. }\end{array}$ \\
\hline $\begin{array}{l}\text { L'observateur et l'expérimentateur } \\
\text { répondraient donc à des phases différentes } \\
\text { de la recherche expérimentale. } \\
\text { L'observateur ne raisonne plus, il constate; } \\
\text { l'expérimentateur, au contraire, raisonne et } \\
\text { se fonde sur les faits acquis pour en imaginer } \\
\text { et en provoquer rationnellement d'autres. } \\
\text { Mais, si l'on peut, dans la théorie et d'une } \\
\text { manière abstraite, distinguer l'observateur } \\
\text { de l'expérimentateur, il semble impossible } \\
\text { dans la pratique de les séparer, puisque } \\
\text { nous voyons que nécessairement le même } \\
\text { investigateur est alternativement } \\
\text { observateur et expérimentateur. }\end{array}$ & $\begin{array}{l}\text { O observador e o experimentador } \\
\text { responderiam, portanto, a fases diferentes } \\
\text { da pesquisa experimental. O observador não } \\
\text { raciocina mais, ele constata; o } \\
\text { experimentador, ao contrário, raciocina e se } \\
\text { baseia nos fatos adquiridos para, a partir } \\
\text { deles, imaginar e provocar outros } \\
\text { racionalmente. Mas, se é possível, na teoria } \\
\text { e de uma maneira abstrata, distinguir o } \\
\text { observador do experimentador, parece } \\
\text { impossível na prática separá-los, pois vemos } \\
\text { que necessariamente o mesmo investigador } \\
\text { é alternadamente observador e } \\
\text { experimentador. }\end{array}$ \\
\hline $\begin{array}{l}\text { C'est en effet ainsi que cela a lieu } \\
\text { constamment quand un même savant } \\
\text { découvre et développe à lui seul toute une } \\
\text { question scientifique. Mais il arrive le plus }\end{array}$ & $\begin{array}{l}\text { De fato, é dessa forma que isso acontece } \\
\text { constantemente quando um mesmo } \\
\text { estudioso descobre e desenvolve sozinho } \\
\text { toda uma questão científica. Mas acontece }\end{array}$ \\
\hline
\end{tabular}


souvent que, dans l'évolution de la science, les diverses parties du raisonnement expérimental sont le partage de plusieurs hommes. Ainsi il en est qui, soit en médecine, soit en histoire naturelle, n'ont fait que recueillir et rassembler des observations; d'autres ont pu émettre des hypothèses plus ou moins ingénieuses et plus ou moins probables fondées sur ces observations; puis d'autres sont venus réaliser expérimentalement les conditions propres à faire naître l'expérience qui devait contrôler ces hypothèses; enfin il en est d'autres qui se sont appliqués plus particulièrement à généraliser et à systématiser les résultats obtenus par les divers observateurs et expérimentateurs. Ce morcellement du domaine expérimental est une chose utile, parce que chacune de ses diverses parties s'en trouve mieux cultivée. On conçoit, en effet, que dans certaines sciences les moyens d'observation et d'expérimentation devenant des instruments tout à fait spéciaux, leur maniement et leur emploi exigent une certaine habitude et réclament une certaine habileté manuelle ou le perfectionnement de certains sens. Mais si j'admets la spécialité pour ce qui est pratique dans la science, je la repousse d'une manière absolue pour tout ce qui est théorique. Je considère en effet que faire sa spécialité des généralités est un principe antiphilosophique et antiscientifique, quoiqu'il ait été proclamé par une école philosophique moderne qui se pique d'être fondée sur les sciences.

Toutefois la science expérimentale ne saurait avancer par un seul des côtés de la méthode pris séparément; elle ne marche que par la réunion de toutes les parties de la méthode concourant vers un but commun. Ceux qui recueillent des observations ne mais frequentemente, na evolução da ciência, que as diversas partes do raciocínio experimental sejam compartilhadas por vários homens. Assim existem aqueles que, seja em medicina, seja em história natural, não fizeram senão recolher e agrupar observações; outros conseguiram emitir hipóteses mais ou menos engenhosas e mais ou menos prováveis baseadas nessas observações; depois, outros vieram realizar experimentalmente as condições adequadas para criar a experiência que devia controlar essas hipóteses; por fim, existem outros que se aplicaram mais particularmente a generalizar e a sistematizar os resultados obtidos pelos diversos observadores e experimentadores. Essa fragmentação do domínio experimental é uma coisa útil, porque cada uma de suas diversas partes se encontra mais bem cultivada. Concebe-se, com efeito, que em certas ciências, tendo os meios de observação e de experimentação se tornado instrumentos absolutamente especiais, seu manuseio e seu emprego exigem uma certa prática e demandam uma certa habilidade manual ou o aperfeiçoamento de certos sentidos. Mas, se admito a especialidade para aquilo que é a prática na ciência, eu a rejeito de uma forma absoluta para tudo o que é teórico. Eu considero, com efeito, que fazer sua especialidade das generalidades é um princípio antifilosófico e anticientífico, ainda que tenha sido proclamado por uma escola filosófica moderna que se orgulha de ser baseada nas ciências.

Todavia, a ciência experimental não poderia avançar somente por um dos pontos de vista do método tomado separadamente; ela não funciona senão pela união de todas as partes do método convergindo para um objetivo comum. Aqueles que recolhem observações 
sont utiles que parce que ces observations sont ultérieurement introduites dans le raisonnement expérimental ; autrement l'accumulation indéfinie d'observations ne conduirait à rien. Ceux qui émettent des hypothèses à propos des observations recueillies par les autres, ne sont utiles qu'autant : que l'on cherchera à vérifier ces hypothèses en expérimentant ; autrement ces hypothèses non vérifiées ou non vérifiables par l'expérience n'engendreraient que des systèmes, et nous reporteraient à la scolastique. Ceux qui expérimentent, malgré toute leur habileté, ne résoudront pas les questions s'ils ne sont inspirés par une hypothèse heureuse fondée sur des observations exactes et bien faites. Enfin ceux qui généralisent ne pourront faire des théories durables qu'autant qu'ils connaîtront par eux-mêmes tous les détails scientifiques que ces théories sont destinées à représenter. Les généralités scientifiques doivent remonter des particularités aux principes; et les principes sont d'autant plus stables qu'ils s'appuient sur des détails plus profonds, de même qu'un pieu est d'autant plus solide qu'il est enfoncé plus avant dans la terre.

On voit donc que tous les termes de la méthode expérimentale sont solidaires les uns des autres. Les faits sont les matériaux nécessaires ; mais c'est leur mise en œuvre par le raisonnement expérimental, c'est-àdire la théorie, qui constitue et édifie véritablement la science. L'idée formulée par les faits représente la science. L'hypothèse expérimentale n'est que l'idée scientifique, préconçue ou anticipée. La théorie n'est que l'idée scientifique contrôlée par l'expérience. Le raisonnement ne sert qu'à donner une forme à nos idées, de sorte que tout se ramène primitivement só são úteis porque essas observações são posteriormente introduzidas no raciocínio experimental; de outro modo, a acumulação indefinida de observações não conduziria a nada. Aqueles que emitem hipóteses a respeito das observações recolhidas pelos outros só são úteis quando: se verificarem essas hipóteses experimentando-as; de outro modo, essas hipóteses não verificadas ou não verificáveis pela experiência não originariam senão sistemas e nos reportariam à escolástica. Aqueles que experimentam, mesmo com toda sua habilidade, não resolverão as questões se não forem inspirados por uma hipótese feliz baseada em observações exatas e bem elaboradas. Finalmente, aqueles que generalizam não poderão propor teorias duráveis enquanto não conhecerem por si mesmos todos os detalhes científicos que essas teorias são destinadas a representar. As generalidades científicas devem ir das particularidades aos princípios; e os princípios, quanto mais se apoiarem em detalhes mais profundos, mais estáveis serão, da mesma forma que uma estaca será mais sólida, quanto mais profundamente for introduzida na terra.

Percebe-se, portanto, que todos os termos do método experimental são solidários uns com os outros. Os fatos são o material necessário; mas é a sua execução pelo raciocínio experimental, isto é, pela teoria, que constitui e edifica verdadeiramente a ciência. A ideia formulada pelos fatos representa a ciência. A hipótese experimental não é senão a ideia científica, preconcebida ou antecipada. A teoria não é senão a ideia científica controlada pela experiência. O raciocínio serve apenas para dar uma forma a nossas ideias, de modo que tudo seja reconduzido primitiva e finalmente 
et finalement à une idée. C'est l'idée qui constitue, ainsi que nous allons le voir, le point de départ ou le primum movens de tout raisonnement scientifique, et c'est elle qui en est également le but dans l'aspiration de l'esprit vers l'inconnu.

\section{Chapitre II}

De l'idée a priori et du doute dans le raisonnement expérimental

Chaque homme se fait de prime abord des idées sur ce qu'il voit, et il est porté à interpréter les phénomènes de la nature par anticipation, avant de les connaître par expérience. Cette tendance est spontanée ; une idée préconçue a toujours été et sera toujours le premier élan d'un esprit investigateur. Mais la méthode expérimentale a pour objet de transformer cette conception a priori fondée sur une intuition ou un sentiment vague des choses, en une interprétation a posteriori établie sur l'étude expérimentale des phénomènes. C'est pourquoi a aussi appelé la méthode expérimentale, la méthode a posteriori.

L'homme est naturellement métaphysicien et orgueilleux ; il a pu croire que les créations idéales de son esprit qui correspondent à ses sentiments représentaient aussi la réalité. D'où il suit que la méthode expérimentale n'est point primitive et naturelle à l'homme, et que ce n'est qu'après avoir erré longtemps dans les discussions théologiques et scolastiques qu'il a fini par reconnaître la stérilité de ses efforts dans cette voie. L'homme s'aperçut alors qu'il ne peut dicter des lois à la nature, a uma ideia. É a ideia que constitui, como veremos, o ponto de partida ou o primum movens de todo raciocínio científico, e é ela que é também o objetivo na aspiração do espírito rumo ao desconhecido.

\section{Capítulo II}

\section{Da ideia a priori e da dúvida no raciocínio experimental}

Cada homem se faz primordialmente das ideias sobre o que ele vê, e ele é levado a interpretar os fenômenos da natureza por antecipação, antes de conhecê-los pela experiência. Essa tendência é espontânea; uma ideia preconcebida sempre foi e sempre será o primeiro impulso de um espírito investigador. Mas o método experimental tem como objetivo transformar essa concepção a priori, baseada numa intuição ou num sentimento vago das coisas, numa interpretação a posteriori estabelecida sobre 0 estudo experimental dos fenômenos. Por esta razão é que também se chamou o método experimental de método a posteriori.

O homem é naturalmente metafísico e orgulhoso; ele chegou a acreditar que as criações ideais de seu espírito, que correspondem a seus sentimentos, também representavam a realidade. Disso resulta que o método experimental não é, de forma alguma, primitivo e natural ao homem, e que foi só depois de ter vagado por muito tempo nas discussões teológicas e escolásticas que ele acabou por reconhecer a esterilidade de seus esforços nesse caminho. O homem então se deu conta de que ele não pode ditar 
parce qu'il ne possède pas en lui-même la connaissance et le critérium des choses extérieures, et il comprit que, pour arriver à la vérité, il doit, au contraire, étudier les lois naturelles et soumettre ses idées, sinon sa raison, à l'expérience, c'est-à-dire au critérium des faits. Toutefois, la manière de procéder de l'esprit humain n'est pas changée au fond pour cela. Le métaphysicien, le scolastique et l'expérimentateur procèdent tous par une idée a priori. La différence consiste en ce que le scolastique impose son idée comme une vérité absolue qu'il a trouvée, et dont il déduit ensuite par la logique seule toutes les conséquences. L'expérimentateur, plus modeste, pose au contraire son idée comme une question, comme une interprétation anticipée de la nature, plus ou moins probable, dont il déduit logiquement des conséquences qu'il confronte à chaque instant avec la réalité au moyen de l'expérience. Il marche ainsi des vérités partielles à des vérités plus générales, mais sans jamais oser prétendre qu'il tient la vérité absolue. Celle-ci, en effet, si on la possédait sur un point quelconque, on l'aurait partout; car l'absolu ne laisse rien en dehors de lui.

L'idée expérimentale est donc aussi une idée a priori, mais c'est une idée qui se présente sous la forme d'une hypothèse dont les conséquences doivent être soumises au critérium expérimental afin d'en juger la valeur. L'esprit de l'expérimentateur se distingue de celui du métaphysicien et du scolastique par la modestie, parce que, à chaque instant, l'expérience lui donne la conscience de son ignorance relative et absolue. En instruisant l'homme, la science expérimentale a pour effet de diminuer de leis à natureza, porque ele não tem dentro de si o conhecimento e o critério das coisas exteriores e ele compreendeu que, para chegar à verdade, ele deve, ao contrário, estudar as leis naturais e submeter suas ideias, ou seja, sua razão, à experiência, isto é, ao critério dos fatos. Todavia, a maneira de proceder do espírito humano, no fundo, não é modificada por isso. O metafísico, o escolástico e o experimentador procedem todos por uma ideia a priori. A diferença consiste em que a escolástica impõe sua ideia como uma verdade absoluta que ele descobriu e a partir da qual ele deduz em seguida, apenas pela lógica, todas as consequências. $O$ experimentador, mais modesto, ao contrário disso, coloca sua ideia como uma questão, como uma interpretação antecipada da natureza, mais ou menos provável, da qual ele deduz logicamente consequências que ele confronta a cada instante com a realidade por meio da experiência. Assim ele progride das verdades parciais a verdades mais gerais, sem, no entanto, jamais ousar afirmar que ele detém a verdade absoluta. Esta, com efeito, caso a possuíssemos sobre um ponto qualquer, nós a teríamos em todos os lugares, pois o absoluto não deixa nada fora de si mesmo.

A ideia experimental também é, portanto, uma ideia a priori, mas é uma ideia que se apresenta sob a forma de uma hipótese cujas consequências devem ser submetidas ao critério experimental a fim de estimar seu valor. O espírito do experimentador se distingue daquele do metafísico e do escolástico pela modéstia, porque a cada instante a experiência lhe dá a consciência de sua ignorância relativa e absoluta. Instruindo o homem, a ciência experimental tem como efeito diminuir cada vez mais seu 
plus en plus son orgueil, en lui prouvant chaque jour que les causes premières, ainsi que la réalité objective des choses, lui seront à jamais cachées, et qu'il ne peut connaître que des relations. C'est là en effet le but unique de toutes les sciences, ainsi que nous le verrons plus loin.

L'esprit humain, aux diverses périodes de son évolution, a passé successivement par le sentiment, la raison et l'expérience. D'abord le sentiment, seul s'imposant à la raison, créa les vérités de foi, c'est-à-dire la théologie. La raison ou la philosophie, devenant ensuite la maîtresse, enfanta la scolastique. Enfin, l'expérience, c'est-à-dire l'étude des phénomènes naturels, apprit à I'homme que les vérités du monde extérieur ne se trouvent formulées de prime abord ni dans le sentiment ni dans la raison. Ce sont seulement nos guides indispensables ; mais, pour obtenir ces vérités, il faut nécessairement descendre dans la réalité objective des choses où elles se trouvent cachées avec leur forme phénoménale.

C'est ainsi qu'apparut par le progrès naturel des choses la méthode expérimentale qui résume tout et qui, comme nous le verrons bientôt, s'appuie successivement sur les trois branches de ce trépied immuable : le sentiment, la raison et l'expérience. Dans la recherche de la vérité, au moyen de cette méthode, le sentiment a toujours l'initiative, il engendre l'idée a priori ou l'intuition; la raison ou le raisonnement développe ensuite l'idée et déduit ses conséquences logiques. Mais si le sentiment doit être éclairé par les lumières de la raison, la raison à son tour doit être guidée par l'expérience. orgulho, provando-lhe a cada dia que as causas primeiras, assim como a realidade objetiva das coisas, para sempre lhe estarão ocultadas e que ele não pode conhecer senão as relações. Aqui se encontra, efetivamente, o objetivo único de todas as ciências, assim como veremos mais adiante.

O espírito humano, nos diversos períodos de sua evolução, passou sucessivamente pelo sentimento, pela razão e pela experiência. Primeiramente, apenas o sentimento, impondo-se à razão, criou as verdades de fé, isto é, a teologia. A razão ou a filosofia, tornando-se em seguida a mestra, produziu a escolástica. Por fim, a experiência, isto é, o estudo dos fenômenos naturais, ensinou ao homem que as verdades do mundo exterior não se encontram formuladas, primordialmente, nem no sentimento, nem na razão. Estes são apenas nossos guias indispensáveis; mas, para obter essas verdades, é preciso necessariamente descer à realidade objetiva das coisas, onde elas estão escondidas em sua forma fenomenal.

Foi assim que surgiu pelo progresso natural das coisas o método experimental, que resume tudo e que, como veremos em seguida, se apoia sucessivamente nos três ramos deste tripé imutável: o sentimento, a razão e a experiência. Na busca da verdade, por meio desse método, o sentimento tem sempre a iniciativa, ele origina a ideia a priori ou a intuição; a razão ou o raciocínio desenvolve em seguida a ideia e deduz suas consequências lógicas. Mas se o sentimento deve ser clareado pelas luzes da razão, a razão, por sua vez, deve ser guiada pela experiência. 


\begin{tabular}{|l|l|}
\hline I & I \\
sont objecrités expérimentives ou extérieures & As verdades experimentais \\
são objetivas ou exteriores
\end{tabular}


n'aient pas besoin d'être vérifiées par l'expérience. Ce serait vouloir mettre les sens au-dessus de la raison, et il serait absurde de chercher à prouver ce qui est vrai absolument pour l'esprit et ce qu'il ne pourrait concevoir autrement.

Mais quand, au lieu de s'exercer sur des rapports subjectifs dont son esprit a créé les conditions, l'homme veut connaître les rapports objectifs de la nature qu'il n'a pas créés, immédiatement le critérium intérieur et conscient lui fait défaut. II a toujours la conscience, sans doute, que dans le monde objectif ou extérieur, la vérité est également constituée par des rapports nécessaires, mais la connaissance des conditions de ces rapports lui manque. II faudrait, en effet, qu'il eût créé ces conditions pour en posséder la connaissance et la conception absolues.

Toutefois l'homme doit croire que les rapports objectifs des phénomènes du monde extérieur pourraient acquérir la certitude des vérités subjectives s'ils étaient réduits à un état de simplicité que son esprit pût embrasser complètement. C'est ainsi que dans l'étude des phénomènes les plus simples, la science expérimentale a saisi certains rapports qui paraissent absolus. Telles sont les propositions qui servent de principes à la mécanique rationnelle et à quelques branches de la physique mathématique. Dans ces sciences, en effet, on raisonne par une déduction logique que l'on ne soumet pas à l'expérience, parce qu'on admet, comme en mathématiques, que, le principe étant vrai, les conséquences le sont aussi. Toutefois, il y a là une grande différence à signaler, en ce sens que le point de départ n'est plus ici une vérité subjective et consciente, mais une vérité objective et inconsciente empruntée à l'observation ou à necessário verificá-las pela experiência. Isso seria querer colocar os sentidos acima da razão e seria absurdo tentar provar aquilo que é absolutamente verdadeiro para o espírito e aquilo que ele não poderia conceber de outra forma.

Mas quando, em vez de se dedicar às relações subjetivas para as quais seu espírito criou as condições, o homem quer conhecer as relações objetivas da natureza que ele não criou, imediatamente o critério interior e consciente lhe faz falta. Ele sempre tem, provavelmente, a consciência de que no mundo objetivo ou exterior, a verdade é constituída igualmente por relações necessárias, mas lhe falta o conhecimento das condições dessas relações. Seria necessário, na verdade, que ele tivesse criado estas condições para delas possuir o conhecimento e a concepção absolutos.

Todavia, o homem deve acreditar que as relações objetivas dos fenômenos do mundo exterior poderiam adquirir a certeza das verdades subjetivas se eles fossem reduzidos a um estado de simplicidade que seu espirito pudesse abraçar completamente. É assim que no estudo dos fenômenos mais simples, a ciência experimental assimilou certas relações que parecem absolutas. Tais são as as proposições que servem de princípios à mecânica racional e a alguns ramos da física matemática. Nestas ciências, efetivamente, raciocina-se por uma dedução lógica que não é submetida à experiência, porque se admite, como na matemática, que, sendo o princípio verdadeiro, as consequências também o são. Todavia, há aqui uma grande diferença a assinalar no sentido de que o ponto de partida nesse caso não é mais uma verdade subjetiva e consciente, mas uma verdade objetiva e inconsciente, 
l'expérience. Or, cette vérité n'est jamais que relative au nombre d'expériences et d'observations qui ont été faites. Si jusqu'à présent aucune observation n'a démenti la vérité en question, l'esprit ne conçoit pas pour cela l'impossibilité que les choses se passent autrement. De sorte que c'est toujours par hypothèse qu'on admet le principe absolu. C'est pourquoi l'application de l'analyse mathématique à des phénomènes naturels, quoique très simples, peut avoir des dangers si la vérification expérimentale est repoussée d'une manière complète. Dans ce cas, l'analyse mathématique devient un instrument aveugle si on ne la retrempe de temps en temps au foyer de l'expérience. J'exprime ici une pensée émise par beaucoup de grands mathématiciens et de grands physiciens, et, pour rapporter une des opinions les plus autorisées en pareille matière, je citerai ce que mon savant confrère et ami $M$. J. Bertrand a écrit à ce sujet dans son bel éloge de Sénarmont : "La géométrie ne doit être pour le physicien qu'un puissant auxiliaire : quand elle a poussé les principes à leurs dernières conséquences, il lui est impossible de faire davantage, et l'incertitude du point de départ ne peut que s'accroître par l'aveugle logique de l'analyse, si l'expérience ne vient à chaque pas servir de boussole et de règle. " emprestada da observação ou da experiência. Porém, essa verdade é sempre relativa apenas ao número de experiências e observações que foram feitos. Se até o presente nenhuma observação desmentiu a verdade em questão, o espírito não concebe para isso a impossibilidade de que as coisas se passem de outra forma. De modo que é sempre por hipótese que se admite o princípio absoluto. É por essa razão que a aplicação da análise matemática a fenômenos naturais, ainda que muito simples, pode apresentar riscos se a verificação experimental for rejeitada integralmente. Nesse caso, a análise matemática se torna um instrumento cego se não for reanimada de tempos em tempos no fogo da experiência. Eu exponho aqui um pensamento emitido por numerosos grandes matemáticos e por grandes físicos e, para me reportar ${ }^{83}$ a uma das opiniões mais autorizadas em tal matéria, eu citarei o que meu sábio colega e amigo M J Bertrand escreveu a esse respeito em sua bela apologia de Sénarmont ${ }^{84}$ : “A geometria não deve ser para o físico senão um poderoso auxiliar: uma vez que ela tenha levado os princípios às suas últimas consequências, é impossível para ela ir além e a incerteza do ponto de partida não pode senão aumentar pela lógica cega da análise se a experiência não vier a cada passo servir de bússola e de norma." 85

\footnotetext{
${ }^{83}$ N.T. Em todos os termos em francês traduzidos para o português, procurou-se trabalhar de forma a traduzir cada um deles sempre por uma mesma palavra, a qual pudesse atender a todos os contextos em que ela ocorresse. No entanto, no caso do verbo rapporter, percebemos que não poderíamos manter essa homogeneidade e decidimos pela sua tradução de forma diferenciada nos diferentes contextos em que ele aparece, mantendo as diferentes colocações em português. No presente caso, foi considerada como a melhor tradução o termo reportar, pois o autor se reporta a uma opinião (ele vai recuperá-la). Em outros contextos, esse mesmo verbo foi traduzido por submeter (submeter os argumentos a, submeter-se às autoridades) e também referir-se (referir-se a uma teoria, referir-se a uma opinião).

84 N.T. SÉNARMONT, Henri Hureau de - mineralogista e físico francês nascido em 1808, distingue-se por suas pesquisas em polarização de cristais. http://www.annales.org/archives/x/senarmont.html

${ }^{85}$ Discurso proferido na 6a jornada pública e anual da Sociedade de apoio aos amigos das ciências.
} 
La mécanique rationnelle et la physique mathématique forment donc le passage entre les mathématiques proprement dites et les sciences expérimentales. Elles renferment les cas les plus simples. Mais, dès que nous entrons dans la physique et dans la chimie, et à plus forte raison dans la biologie, les phénomènes se compliquent de rapports tellement nombreux, que les principes représentés par les théories, auxquels nous avons pu nous élever, ne sont que provisoires et tellement hypothétiques, que nos déductions, bien que très logiques, sont complètement incertaines, et ne sauraient dans aucun cas se passer de la vérification expérimentale.

En un mot, l'homme peut rapporter tous ses raisonnements à deux critériums, l'un intérieur et conscient, qui est certain et absolu ; l'autre extérieur et inconscient, qui est expérimental et relatif.

Quand nous raisonnons sur les objets extérieurs, mais en les considérant par rapport à nous suivant l'agrément ou le désagrément qu'ils nous causent, suivant leur utilité ou leurs inconvénients, nous possédons encore dans nos sensations un critérium intérieur. De même, quand nous raisonnons sur nos propres actes, nous avons également un guide certain, parce que nous avons conscience de ce que nous pensons et de ce que nous sentons. Mais si nous voulons juger les actes d'un autre homme et savoir les mobiles qui le font agir, c'est tout différent. Sans doute nous avons devant les yeux les mouvements de cet homme et ses manifestations qui sont, nous en sommes sûrs, les modes d'expression de sa sensibilité et de sa volonté. De plus nous admettons encore qu'il y a un rapport nécessaire entre les actes et leur cause ;
A mecânica racional e a física matemática constituem, assim, a passagem entre a matemática propriamente dita e as ciências experimentais. Elas encerram os casos mais simples. Mas, a partir do momento que entramos na física e na química, e com mais forte razão na biologia, os fenômenos se complicam com relações de tal forma numerosas, que os princípios representados pelas teorias aos quais pudemos nos alçar são apenas provisórios e tão hipotéticos que nossas deduções, ainda que bastante lógicas, são completamente incertas e não poderiam, em caso algum, dispensar a verificação experimental.

Em uma palavra, o homem pode submeter todos os seus pensamentos a dois critérios, um interior e consciente, que é certo e absoluto; o outro exterior e inconsciente, que é experimental e relativo.

Quando refletimos sobre os objetos exteriores, mas considerando-os em relação a nós segundo a satisfação ou insatisfação que eles nos causam, segundo sua utilidade ou seus inconvenientes, possuímos ainda em nossas sensações um critério interior. Da mesma forma, quando refletimos sobre nossos próprios atos, temos também um guia certo, porque temos consciência do que pensamos e do que sentimos. Mas, se quisermos julgar os atos de um outro homem e conhecer as motivações que o fazem agir, isso é completamente diferente. Provavelmente, temos diante dos olhos os movimentos deste homem e suas manifestações que são, disso estamos certos, os modos de expressão de sua sensibilidade e de sua vontade. Além disso, admitimos ainda que há uma relação necessária entre os atos e sua causa; mas 
mais quelle est cette cause ? Nous ne la sentons pas en nous, nous n'en avons pas conscience comme quand il s'agit de nousmême; nous sommes donc obligés de l'interpréter et de la supposer d'après les mouvements que nous voyons et les paroles que nous entendons. Alors nous devons contrôler les actes de cet homme les uns par les autres; nous considérons comment il agit dans telle ou telle circonstance, et, en un mot, nous recourons à la méthode expérimentale. De même quand le savant considère les phénomènes naturels qui l'entourent et qu'il veut les connaître en eux-mêmes et dans leurs rapports mutuels et complexes de causalité, tout critérium intérieur lui fait défaut, et il est obligé d'invoquer l'expérience pour contrôler les suppositions et les raisonnements qu'il fait à leur égard. L'expérience, suivant l'expression de Goethe, devient alors la seule médiatrice entre l'objectif et le subjectif, c'est-à-dire entre le savant et les phénomènes qui l'environnent.

Le raisonnement expérimental est donc le seul que le naturaliste et le médecin puissent employer pour chercher la vérité et en approcher autant que possible. En effet, par sa nature même de critérium extérieur et inconscient, l'expérience ne donne que la vérité relative sans jamais pouvoir prouver à l'esprit qu'il la possède d'une manière absolue.

L'expérimentateur qui se trouve en face des phénomènes naturels ressemble à un spectateur qui observe des scènes muettes. Il est en quelque sorte le juge d'instruction que causa é essa? Nós não a sentimos em nós, não temos consciência dela como quando se trata de nós mesmos; somos, portanto, obrigados a interpretá-la e a supôla a partir dos movimentos que vemos e das palavras que ouvimos. Então, devemos controlar os atos desse homem, uns pelos outros; consideramos como ele age em tais e tais circunstâncias e, em uma palavra, recorremos ao método experimental. Da mesma forma, quando o estudioso considera os fenômenos naturais que o rodeiam e que ele quer conhecer em si mesmos e nas suas relações mútuas e complexas de causalidade, todo critério interior lhe faz falta e ele é obrigado a criar invocar a experiência para controlar as suposições e os raciocínios que ele faz a seu respeito. A experiência, segundo a expressão de Goethe, torna-se então a única mediadora entre o objetivo e o subjetivo ${ }^{86}$, isto é, entre o estudioso e os fenômenos que o rodeiam.

O raciocínio experimental é, portanto, o único que o naturalista e o médico podem empregar para buscar a verdade e dela se aproximar o máximo possível. Na verdade, por sua própria natureza de critério exterior e inconsciente, a experiência apenas fornece a verdade relativa, sem jamais poder provar ao espírito que ele a possui de uma maneira absoluta.

O experimentador que se encontra diante dos fenômenos naturais assemelha-se a um espectador que observa cenas mudas. Ele é, de alguma forma, o juiz ${ }^{87}$ da natureza; só

${ }^{86}$ Goethe, CEuvres d'histoire naturelle, traduction de M. Martine. Introduction, p. 1

${ }^{87}$ N.T. No original, ele usa o termo juge d'instruction, para o qual não foi encontrado nenhum correspondente em língua portuguesa, razão pela qual optamos pela tradução deste termo simplesmente por juiz. Exemplos do uso desse termo em francês podem ser encontrados em http://cnrtl.fr/definition/juge 
de la nature ; seulement, au lieu d'être aux prises avec des hommes qui cherchent à le tromper par des aveux mensongers ou par de faux témoignages, il a affaire à des phénomènes naturels qui sont pour lui des personnages dont il ne connaît ni le langage ni les mœurs, qui vivent au milieu de circonstances qui lui sont inconnues, et dont il veut cependant savoir les intentions. Pour cela il emploie tous les moyens qui sont en sa puissance. Il observe leurs actions, leur marche, leurs manifestations, et il cherche à en démêler la cause au moyen de tentatives diverses, appelées expériences. II emploie tous les artifices imaginables et, comme on le dit vulgairement, il plaide souvent le faux pour savoir le vrai. Dans tout cela l'expérimentateur raisonne nécessairement d'après lui-même et prête à la nature ses propres idées. Il fait des suppositions sur la cause des actes qui se passent devant lui, et, pour savoir si l'hypothèse qui sert de base à son interprétation est juste, il s'arrange pour faire apparaître des faits, qui, dans l'ordre logique, puissent être la confirmation ou la négation de l'idée qu'il a conçue. Or, je le répète, c'est ce contrôle logique qui seul peut l'instruire et lui donner l'expérience. Le naturaliste qui observe des animaux dont il veut connaître les mœurs et les habitudes, le physiologiste et le médecin qui veulent étudier les fonctions cachées des corps vivants, le physicien et le chimiste qui déterminent les phénomènes de la matière brute ; tous sont dans le même cas, ils ont devant eux des manifestations qu'ils ne peuvent interpréter qu'à l'aide du critérium expérimental, le seul dont nous ayons à nous occuper ici. que, em vez de se debater com os homens que buscam enganá-lo com confissões mentirosas ou com falsos testemunhos, ele tem que se confrontar com fenômenos naturais que são personagens dos quais ele não conhece nem a linguagem nem os costumes, que vivem em circunstâncias que Ihe são desconhecidas e cujas intenções, no entanto, ele quer conhecer. Para isso ele emprega todos os meios que tem em seu poder. Ele observa suas ações, sua evolução, suas manifestações e ele procura decifrar a causa por meio de tentativas diversas, chamadas experiências. Ele emprega todos os artifícios imagináveis e, como se diz na linguagem popular, ele frequentemente contesta o falso para conhecer o verdadeiro. Nisso tudo, o experimentador raciocina necessariamente de acordo com ele mesmo e oferece à natureza suas próprias ideias. Ele faz suposições sobre a causa dos atos que se passam diante dele e, para saber se a hipótese que serve de base à sua interpretação é correta, ele busca formas de fazer aparecerem os fatos que, na ordem lógica, possam representar a confirmação ou a negação da ideia que ele concebeu. Logo, eu repito, somente esse controle lógico é que pode instruí-lo e lhe dar a experiência. 0 naturalista que observa animais cujos modos e hábitos ele deseja conhecer, o fisiologista e o médico que desejam estudar as funções escondidas de corpos vivos, o físico e o químico que determinam os fenômenos da matéria bruta; todos estão no mesmo caso, eles têm diante deles manifestações que eles não podem interpretar senão com a ajuda do critério experimental, o único do qual temos que nos ocupar aqui. 


\begin{tabular}{|c|c|}
\hline $\begin{array}{l}\text { Il } \\
\text { L'intuition ou le sentiment } \\
\text { engendre l'idée expérimentale }\end{array}$ & $\begin{array}{l}\text { II } \\
\text { A intuição ou o sentimento } \\
\text { origina a ideia experimental }\end{array}$ \\
\hline $\begin{array}{l}\text { Nous avons dit plus haut que la méthode } \\
\text { expérimentale s'appuie successivement sur } \\
\text { le sentiment, la raison et l'expérience. }\end{array}$ & $\begin{array}{l}\text { Nós dissemos anteriormente que o método } \\
\text { experimental se apoia sucessivamente sobre } \\
\text { o sentimento, a razão e a experiência. }\end{array}$ \\
\hline $\begin{array}{l}\text { Le sentiment engendre l'idée oul'hypothèse } \\
\text { expérimentale, c'est-à-dire l'interprétation } \\
\text { anticipée des phénomènes de la nature. } \\
\text { Toute l'initiative expérimentale est dans } \\
\text { l'idée, car c'est elle qui provoque } \\
\text { l'expérience. La raison ou le raisonnement } \\
\text { ne servent qu'à déduire les conséquences } \\
\text { de cette idée et à les soumettre à } \\
\text { l'expérience. }\end{array}$ & $\begin{array}{l}\text { O sentimento origina a ideia ou hipótese } \\
\text { experimental, isto é, a interpretação } \\
\text { antecipada dos fenômenos da natureza. } \\
\text { Toda iniciativa experimental está na ideia, } \\
\text { pois é ela que produz a experiência. A razão } \\
\text { ou o raciocínio servem apenas para deduzir } \\
\text { as consequências desta ideia e submetê-las } \\
\text { à experiência. }\end{array}$ \\
\hline $\begin{array}{l}\text { Une idée anticipée ou une hypothèse est } \\
\text { donc le point de départ nécessaire de tout } \\
\text { raisonnement expérimental. Sans cela on ne } \\
\text { saurait faire aucune investigation ni } \\
\text { s'instruire; on ne pourrait qu'entasser des } \\
\text { observations stériles. Si l'on expérimentait } \\
\text { sans idée préconçue, on irait à l'aventure ; } \\
\text { mais d'un autre côté, ainsi que nous l'avons } \\
\text { dit ailleurs, si l'on observait avec des idées } \\
\text { préconçues, on ferait de mauvaises } \\
\text { observations et l'on serait exposé à prendre } \\
\text { les conceptions de son esprit pour la réalité. }\end{array}$ & $\begin{array}{l}\text { Uma ideia antecipada ou uma hipótese é, } \\
\text { portanto, o ponto de partida necessário a } \\
\text { todo raciocínio experimental. Sem isso, não } \\
\text { se poderia fazer qualquer investigação ou } \\
\text { instruir-se; só se poderia acumular } \\
\text { observações } \text { estéreis. } \\
\text { experimentássemos sem ideia preconcebida, } \\
\text { isso nos levaria à aventura; mas, por outro } \\
\text { lado, assim como dissemos anteriormente, } \\
\text { se observássemos tendo ideias } \\
\text { preconcebidas, faríamos observações ruins e } \\
\text { estaríamos sujeitos a tomar por realidade as } \\
\text { concepções do espírito. }^{88}\end{array}$ \\
\hline $\begin{array}{l}\text { Les idées expérimentales ne sont point } \\
\text { innées. Elles ne surgissent point } \\
\text { spontanément, il leur faut une occasion ou } \\
\text { un excitant extérieur, comme cela a } \\
\text { lieu dans toutes les fonctions } \\
\text { physiologiques. Pour avoir une première }\end{array}$ & $\begin{array}{l}\text { As ideias experimentais não são de forma } \\
\text { alguma inatas. Elas não surgem } \\
\text { espontaneamente, elas precisam de uma } \\
\text { ocasião ou de um estímulo exterior, como } \\
\text { acontece com todas as funções fisiológicas. } \\
\text { Para se ter uma ideia inicial das coisas, é } \\
\text { preciso ver essas coisas; para se ter uma }\end{array}$ \\
\hline
\end{tabular}

\footnotetext{
${ }^{88}$ N.T. Neste parágrafo, julgamos difícil traduzir on na forma impessoal, como optamos por fazer ao longo de todo o restante da obra (observamos que quando se trata de nós, ele aplica o pronome nous e não a forma on). Por conta dessa dificuldade, traduzimos este termo, apenas neste caso, por nós. Desta forma, pudemos manter os verbos que ele enfatiza (experimentar e observar), bem como o verbo no condicional.
} 
idée des choses, il faut voir ces choses; pour avoir une idée sur un phénomène de la nature, il faut d'abord l'observer. L'esprit de l'homme ne peut concevoir un effet sans cause, de telle sorte que la vue d'un phénomène éveille toujours en lui une idée de causalité. Toute la connaissance humaine se borne à remonter des effets observés à leur cause. A la suite d'une observation, une idée relative à la cause du phénomène observé se présente à l'esprit ; puis on introduit cette idée anticipée dans un raisonnement en vertu duquel on fait des expériences pour la contrôler.

Les idées expérimentales, comme nous le verrons plus tard, peuvent naître soit à propos d'un fait observé par hasard, soit à la suite d'une tentative expérimentale, soit comme corollaires d'une théorie admise. Ce qu'il faut seulement noter pour le moment, c'est que l'idée expérimentale n'est point arbitraire ni purement imaginaire ; elle doit avoir toujours un point d'appui dans la réalité observée, c'est-à-dire dans la nature. L'hypothèse expérimentale, en un mot, doit toujours être fondée sur une observation antérieure. Une autre condition essentielle de l'hypothèse, c'est qu'elle soit aussi probable que possible et qu'elle soit vérifiable expérimentalement. En effet, si I'on faisait une hypothèse que l'expérience ne pût pas vérifier, on sortirait par cela même de la méthode expérimentale pour tomber dans les défauts des scolastiques et des systématiques.

II n'y a pas de règles à donner pour faire naître dans le cerveau, à propos d'une observation donnée, une idée juste et féconde qui soit pour l'expérimentateur une sorte d'anticipation intuitive de l'esprit vers une recherche heureuse. L'idée une fois émise, on peut seulement dire comment il faut la soumettre à des préceptes définis et ideia sobre um fenômeno da natureza, é preciso primeiro observá-lo. O espírito do homem não pode conceber um efeito sem causa, de tal modo que a visão de um fenômeno sempre desperte nele uma ideia de causalidade. Todo o conhecimento humano limita-se a relacionar efeitos observados às suas causas. Após uma observação, uma ideia relativa à causa do fenômeno observado se apresenta ao espírito; depois se introduz essa ideia antecipada em um raciocínio em virtude do qual se fazem experiências para verificá-la.

As ideias experimentais, como veremos mais adiante, podem nascer seja pela proposição de um fato observado por acaso, seja como resultado de uma tentativa experimental, seja como corolárias de uma teoria admitida. Só o que é preciso observar nesse momento é que a ideia experimental não é de forma alguma arbitrária, nem puramente imaginária; ela deve ter sempre um ponto de apoio na realidade observada, isto é, na natureza. A hipótese experimental, em resumo, deve ser sempre baseada numa observação anterior. Uma outra condição essencial da hipótese é que ela seja tão provável quanto possível e que ela seja verificável experimentalmente. Na verdade, se se fizesse uma hipótese que a experiência não pudesse verificar, isso resultaria deixar o método experimental para cair nos defeitos dos escolásticos e dos sistemáticos.

Não há regras para fazer nascer no cérebro, em relação a uma dada observação, uma ideia precisa e fecunda que seja para o experimentador uma espécie de antecipação intuitiva do espírito rumo a uma pesquisa bem-sucedida. Uma vez emitida a ideia, pode-se apenas dizer como submetêla a preceitos definidos e a regras lógicas 
à des règles logiques précises dont aucun expérimentateur ne saurait s'écarter ; mais son apparition a été toute spontanée, et sa nature est tout individuelle. C'est un sentiment particulier, un quid proprium qui constitue l'originalité, l'invention ou le génie de chacun. Une idée neuve apparaît comme une relation nouvelle ou inattendue que l'esprit aperçoit entre les choses. Toutes les intelligences se ressemblent sans doute et des idées semblables peuvent naître chez tous les hommes, à l'occasion de certains rapports simples des objets que tout le monde peut saisir. Mais comme les sens, les intelligences n'ont pas toutes la même puissance ni la même acuité, et il est des rapports subtils et délicats qui ne peuvent être sentis, saisis et dévoilés que par des esprits plus perspicaces, mieux doués ou placés dans un milieu intellectuel qui les prédispose d'une manière favorable.'

Si les faits donnaient nécessairement naissance aux idées, chaque fait nouveau devrait engendrer une idée nouvelle. Cela a lieu, il est vrai, le plus souvent; car il est des faits nouveaux qui, par leur nature, font venir la même idée nouvelle à tous les hommes placés dans les mêmes conditions d'instruction antérieure. Mais il est aussi des faits qui ne disent rien à l'esprit du plus grand nombre, tandis qu'ils sont lumineux pour d'autres. Il arrive même qu'un fait ou une observation reste très longtemps devant les yeux d'un savant sans lui rien inspirer; puis tout à coup vient un trait de lumière, et l'esprit interprète le même fait tout autrement qu'auparavant et lui trouve des rapports tout nouveaux. L'idée neuve apparaît alors avec la rapidité de l'éclair comme une sorte de révélation subite; ce qui prouve bien que dans ce cas la découverte réside dans un sentiment des choses qui est non seulement personnel, precisas de que nenhum experimentador poderia se desvencilhar; mas sua aparição foi totalmente espontânea e sua natureza é totalmente individual. É um sentimento particular, um quid proprium que constitui a originalidade, a invenção ou o gênio de cada um. Uma ideia nova aparece como uma relação nova ou inesperada que o espírito percebe em meio às coisas. Todas as inteligências se parecem, provavelmente, e ideias semelhantes podem nascer em todos os homens, por ocasião de certas relações simples dos objetos que todo mundo pode captar. Mas, assim como os sentidos, as inteligências não têm todas o mesmo poder nem a mesma acuidade e existem relações sutis e delicadas, que podem apenas ser sentidas, captadas e desveladas pelos espíritos mais perspicazes, mais bemdotados ou situados em um meio intelectual que os predispõe de uma maneira favorável.

Se os fatos dessem necessariamente origem às ideias, cada fato novo deveria dar origem a uma ideia nova. Isso é o que acontece, é verdade, com mais frequência; pois são fatos novos que, por sua natureza, suscitam a mesma ideia nova em todos os homens situados nas mesmas condições de instrução prévia. Mas também há fatos que não dizem nada ao espírito da grande maioria, enquanto são luminosos para outros. Acontece até mesmo que um fato ou uma observação fique muito tempo diante dos olhos de um estudioso, sem nada lhe inspirar; até que, repentinamente, surge um traço de luz e o espírito interpreta o mesmo fato de forma completamente diferente da anterior e descobre relações completamente novas. A ideia nova aparece então com a rapidez de um relâmpago, como uma espécie de revelação súbita, o que bem prova que, neste caso, a descoberta reside em um sentimento das 
mais qui est même relatif à l'état actuel dans lequel se trouve l'esprit.

La méthode expérimentale ne donnera donc pas des idées neuves et fécondes à ceux qui n'en ont pas; elle servira seulement à diriger les idées chez ceux qui en ont et à les développer afin d'en retirer les meilleurs résultats possibles. L'idée, c'est la graine ; la méthode, c'est le sol qui lui fournit les conditions de se développer, de prospérer et de donner les meilleurs fruits suivant sa nature. Mais de même qu'il ne poussera jamais dans le sol que ce qu'on y sème, de même il ne se développera par la méthode expérimentale que les idées qu'on lui soumet. La méthode par elle-même n'enfante rien, et c'est une erreur de certains philosophes d'avoir accordé trop de puissance à la méthode sous ce rapport.

L'idée expérimentale résulte d'une sorte de pressentiment de l'esprit qui juge que les choses doivent se passer d'une certaine manière. On peut dire sous ce rapport que nous avons dans l'esprit l'intuition ou le sentiment des lois de la nature, mais nous n'en connaissons pas la forme. L'expérience peut seule nous l'apprendre.

Les hommes qui ont le pressentiment des vérités nouvelles sont rares; dans toutes les sciences, le plus grand nombre des hommes développe et poursuit les idées d'un petit nombre d'autres. Ceux qui font des découvertes sont les promoteurs d'idées neuves et fécondes. On donne généralement le nom de découverte à la connaissance d'un fait nouveau; mais je pense que c'est l'idée qui se rattache au fait découvert qui constitue en réalité la découverte. Les faits ne sont ni grands ni petits par eux-mêmes. Une grande coisas que não é apenas pessoal, mas também tem a ver com o estado atual no qual se encontra o espírito.

O método experimental não dará, portanto, ideias novas e fecundas àqueles que não as têm; ele servirá apenas para guiar as ideias dos que já as têm e para desenvolvê-las, a fim de obter a partir delas os melhores resultados possíveis. A ideia é a semente; o método é o solo que lhe fornece as condições para se desenvolver, prosperar e dar os melhores frutos, de acordo com a sua natureza. Mas, da mesma forma que só crescerá no solo aquilo que se semeou, só se desenvolverão pelo método experimental as ideias que a ele forem submetidas. 0 método por si só não cria nada e é um erro de certos filósofos ter atribuído demasiado poder ao método a esse respeito.

A ideia experimental resulta de uma espécie de pressentimento do espírito que julga que as coisas devem se passar de uma certa maneira. Pode-se dizer em relação a isso que temos no espírito a intuição ou o sentimento das leis da natureza, mas nós não conhecemos sua forma. Somente a experiência nos pode ensiná-la.

Os homens que têm o pressentimento das novas verdades são raros; em todas as ciências, a maior parte dos homens desenvolve e dá continuidade às as ideias de uns poucos outros. Os que fazem as descobertas são os promotores de ideias novas e fecundas. Geralmente se dá o nome de descoberta ao conhecimento de um fato novo; mas eu penso que é a ideia que se liga ao fato descoberto que constitui, na verdade, a descoberta. Os fatos em si não são nem grandes, nem pequenos. Uma grande descoberta é um fato que, tendo 
découverte est un fait qui, en apparaissant dans la science, a donné naissance à des idées lumineuses, dont la clarté a dissipé un grand nombre d'obscurités et montré les voies nouvelles. Il y a d'autres faits qui, bien que nouveaux, n'apprennent que peu de chose ; ce sont alors de petites découvertes. Enfin il y a des faits nouveaux qui, quoique bien observés, n'apprennent rien à personne ; ils restent, pour le moment, isolés et stériles dans la science ; c'est ce qu'on pourrait appeler le fait brut ou le fait brutal.

La découverte est donc l'idée neuve qui surgit à propos d'un fait trouvé par hasard ou autrement. Par conséquent, il ne saurait y avoir de méthode pour faire des découvertes, parce que les théories philosophiques ne peuvent pas plus donner le sentiment inventif et la justesse de l'esprit à ceux qui ne les possèdent pas, que la connaissance des théories acoustiques ou optiques ne peut donner une oreille juste ou une bonne vue à ceux qui en sont naturellement privés. Seulement les bonnes méthodes peuvent nous apprendre à développer et à mieux utiliser les facultés que la nature nous a dévolues, tandis que les mauvaises méthodes peuvent nous empêcher d'en tirer un heureux profit. C'est ainsi que le génie de l'invention, si précieux dans les sciences, peut être diminué ou même étouffé par une mauvaise méthode, tandis qu'une bonne méthode peut l'accroître et le développer. En un mot, une bonne méthode favorise le développement scientifique et prémunit le savant contre les causes d'erreurs si nombreuses qu'il rencontre dans la recherche de la vérité ; c'est là le seul objet que puisse se proposer la méthode expérimentale. Dans les sciences biologiques, ce rôle de la méthode est encore plus important que dans les aparecido na ciência, deu origem a ideias luminosas, cuja claridade dissipou um grande número de obscuridades e mostrou os novos caminhos. Há outros fatos que, embora novos, ensinam apenas poucas coisas; são, então, pequenas descobertas. Finalmente, há fatos novos que, embora bem observados, não ensinam nada a ninguém; eles permanecem momentaneamente isolados e estéreis na ciência; é o que se poderia chamar de fato bruto ou fato grosseiro.

A descoberta é, portanto, a ideia nova que surge a respeito de um fato encontrado por acaso ou de outra forma. Consequentemente, não se poderia ter um método para fazer as descobertas, pois as teorias filosóficas não podem dar mais sentimento inventivo e justeza de espírito aos que não os possuem, assim como o conhecimento das teorias acústicas ou ópticas não pode dar um ouvido apurado ou uma boa visão àqueles que são naturalmente privados deles. Somente os bons métodos podem nos ensinar a desenvolver e a utilizar melhor as faculdades que a natureza nos reservou, ao passo que os métodos ruins podem nos impedir de tirar delas um bom proveito. É assim que o gênio da invenção, tão precioso nas ciências, pode ser diminuído ou mesmo sufocado por um método ruim, ao passo que um bom método pode fazê-lo crescer e se desenvolver. Em uma palavra, um bom método favorece o desenvolvimento científico e protege o estudioso contra as causas de erros tão numerosos que ele encontra na busca da verdade; é esse o único objeto ao qual pode se propor o método experimental. Nas ciências biológicas, esse papel do método é ainda mais importante do que nas outras, devido à imensa complexidade dos 
autres, par suite de la complexité immense des phénomènes et des causes d'erreurs sans nombre que cette complexité introduit dans l'expérimentation. Toutefois, même au point de vue biologique, nous ne saurions avoir la prétention de traiter ici de la méthode expérimentale d'une manière complète ; nous devons nous borner à donner quelques principes généraux, qui pourront guider l'esprit de celui qui se livre aux recherches de médecine expérimentale.

\section{III \\ L'expérimentateur doit douter, fuir les idées fixes et garder toujours sa liberté d'esprit}

La première condition que doit remplir un savant qui se livre à l'investigation dans les phénomènes naturels, c'est de conserver une entière liberté d'esprit assise sur le doute philosophique. II ne faut pourtant point être sceptique; il faut croire à la science, c'est-à-dire au déterminisme, au rapport absolu et nécessaire des choses, aussi bien dans les phénomènes propres aux êtres vivants que dans tous les autres; mais il faut en même temps être bien convaincu que nous n'avons ce rapport que d'une manière plus ou moins approximative, et que les théories que nous possédons sont loin de représenter des vérités immuables. Quand nous faisons une théorie, générale dans nos sciences, la seule chose dont nous soyons certains, c'est que toutes ces théories sont fausses absolument parlant. Elles ne sont que des vérités partielles et provisoires qui nous sont nécessaires, comme des degrés sur lesquels nous nous reposons, pour avancer dans l'investigation ; elles ne représentent que l'état actuel de nos connaissances, et, par conséquent, elles fenômenos e das causas de erros inumeráveis que tal complexidade introduz na experimentação. Todavia, mesmo sob o ponto de vista biológico, não poderíamos ter a pretensão de tratar aqui do método experimental de uma maneira completa; devemos nos limitar a fornecer alguns princípios gerais, que poderão guiar o espírito daquele que se dedica às pesquisas em medicina experimental.

\section{III}

O experimentador deve duvidar, evitar as ideias fixas e conservar sempre sua liberdade de espírito

A primeira condição que deve preencher um estudioso que se dedica à investigação dos fenômenos naturais é a de conservar uma total liberdade de espírito assentada sobre a dúvida filosófica. Não é preciso, no entanto, de forma alguma ser cético; é preciso acreditar na ciência, isto é, no determinismo, na relação absoluta e necessária das coisas, tanto nos fenômenos próprios aos seres vivos como em todos os outros; mas é preciso ao mesmo tempo estar bem convencido de que nós não temos essa relação senão de uma maneira mais ou menos aproximativa e que as teorias que possuímos estão longe de representar verdades imutáveis. Quando fazemos uma teoria, geral em nossas ciências, a única coisa de que temos certeza é que todas essas teorias são falsas, absolutamente falando. Elas são apenas verdades parciais e provisórias que nos são necessárias, como degraus sobre os quais descansamos para avançar na investigação; elas apenas representam o estado atual de nossos conhecimentos e, consequentemente, elas 
devront se modifier avec l'accroissement de la science, et d'autant plus souvent que les sciences sont moins avancées dans leur évolution. D'un autre côté, nos idées, ainsi que nous l'avons dit, nous viennent à la vue de faits qui ont été préalablement observés et que nous interprétons ensuite. Or, des causes d'erreurs sans nombre peuvent se glisser dans nos observations, et, malgré toute notre attention et notre sagacité, nous ne sommes jamais sûrs d'avoir tout vu, parce que souvent les moyens de constatation nous manquent ou sont trop imparfaits. De tout cela, il résulte donc que, si le raisonnement nous guide dans la science expérimentale, il ne nous impose pas nécessairement ses conséquences. Notre esprit peut toujours rester libre de les accepter ou de les discuter. Si une idée se présente à nous, nous ne devons pas la repousser par cela seul qu'elle n'est pas d'accord avec les conséquences logiques d'une théorie régnante. Nous pouvons suivre notre sentiment et notre idée, donner carrière à notre imagination, pourvu que toutes nos idées ne soient que des prétextes à instituer des expériences nouvelles qui puissent nous fournir des faits probants ou inattendus et féconds.

Cette liberté que garde l'expérimentateur est, ainsi que je l'ai dit, fondée sur le doute philosophique. En effet, nous devons avoir conscience de l'incertitude de nos raisonnements à cause de l'obscurité de leur point de départ. Ce point de départ repose toujours au fond sur des hypothèses ou sur des théories plus ou moins imparfaites, suivant l'état d'avancement des sciences. En biologie et particulièrement en médecine, les théories sont si précaires que l'expérimentateur garde presque toute sa liberté. En chimie et en physique les faits deviennent plus simples, les sciences sont deverão se modificar com o crescimento da ciência e tanto mais frequentemente quanto menos avançadas forem as ciências em sua evolução. Por outro lado, nossas ideias, como dissemos, nos são mostradas a partir de fatos que foram previamente observados e que interpretamos em seguida. Porém, causas de erros incontáveis podem escapar em nossas observações e, apesar de toda nossa atenção e nossa sagacidade, nunca estamos seguros de ter visto tudo, porque frequentemente os meios de constatação nos faltam ou são imperfeitos demais. Disso tudo resulta, portanto, que, se o raciocínio nos guia na ciência experimental, ele não nos impõe necessariamente suas consequências. Nosso espírito pode sempre se manter livre para aceitá-las ou discuti-las. Se uma ideia se nos apresenta, não devemos refutá-la somente porque ela não está de acordo com as consequências lógicas de uma teoria reinante. Nós podemos seguir nosso sentimento e nossa ideia, dar asas à nossa imaginação, desde que todas as nossas ideias sejam apenas pretextos para instituir experiências novas que possam nos fornecer fatos conclusivos ou inesperados e fecundos.

Essa liberdade que conserva o experimentador é, como eu já disse, baseada na dúvida filosófica. De fato, devemos ter consciência da incerteza de nossos raciocínios devido à obscuridade de seu ponto de partida. Este ponto de partida reside sempre, no fundo, em hipóteses ou teorias mais ou menos imperfeitas, de acordo com o estado de avanço das ciências. Em biologia e particularmente em medicina, as teorias são tão precárias que o experimentador preserva quase toda sua liberdade. Em química e em física, os fatos tornam-se mais simples, as ciências são mais 
plus avancées, les théories sont plus assurées, et l'expérimentateur doit en tenir un plus grand compte et accorder une plus grande importance aux conséquences du raisonnement expérimental fondé sur elles. Mais encore ne doit-il jamais donner une valeur absolue à ces théories. De nos jours, on a vu des grands physiciens faire des découvertes du premier ordre à l'occasion d'expériences instituées d'une manière illogique par rapport aux théories admises. L'astronomie a assez de confiance dans les principes de sa science pour construire avec eux des théories mathématiques, mais cela ne l'empêche pas de les vérifier et de les contrôler par des observations directes; ce précepte même, ainsi que nous l'avons vu, ne doit pas être négligé en mécanique rationnelle. Mais dans les mathématiques, quand on part d'un axiome ou d'un principe dont la vérité est absolument nécessaire et consciente, la liberté n'existe plus; les vérités acquises sont immuables. Le géomètre n'est pas libre de mettre en doute si les trois angles d'un triangle sont égaux ou non à deux droits ; par conséquent, il n'est pas libre de rejeter les conséquences logiques qui se déduisent de ce principe.

Si un médecin se figurait que ses raisonnements ont la valeur de ceux d'un mathématicien, il serait dans la plus grande des erreurs et il serait conduit aux conséquences les plus fausses. C'est malheureusement ce qui est arrivé et ce qui arrive encore pour les j'appellerai des systématiques. En effet, ces hommes partent d'une idée fondée plus ou moins sur l'observation et qu'ils considèrent comme une vérité absolue. Alors ils raisonnent logiquement et sans expérimenter, et arrivent, de conséquence en conséquence, à construire un système qui est logique, mais avançadas, as teorias são mais confirmadas e o experimentador deve considerar ainda mais isso e atribuir uma maior importância às consequências do raciocínio experimental baseado nelas. Mas, ainda assim, ele nunca deve dar um valor absoluto a essas teorias. Nos dias de hoje, vimos grandes físicos fazendo descobertas de primeira linha, graças a experiências instituídas de uma maneira ilógica em relação às teorias reconhecidas. A astronomia tem confiança suficiente nos princípios de sua ciência para com eles construir teorias matemáticas, mas isso não a impede de verificá-los e de controlá-los por observações diretas; mesmo esse preceito, assim como vimos, não deve ser negligenciado em mecânica racional. Mas na matemática, quando se parte de um axioma ou de um princípio cuja verdade é absolutamente necessária e consciente, a liberdade não existe mais; as verdades adquiridas são imutáveis. O geômetra não é livre para colocar em dúvida se os três ângulos de um triângulo são ou não iguais a dois ângulos retos; consequentemente, ele não é livre para rejeitar as consequências lógicas que se deduzem desse princípio.

Se um médico imaginasse que seus raciocínios têm o valor dos de um matemático, ele cairia no maior dos erros e seria conduzido às consequências mais falsas. Infelizmente, foi o que aconteceu e ainda acontece com aqueles que chamarei de sistemáticos. Efetivamente, esses homens partem de uma ideia mais ou menos baseada na observação e que eles consideram como uma verdade absoluta. Então eles raciocinam logicamente, sem experimentar, e chegam, de consequência em consequência, a construir um sistema que é lógico, mas que não possui nenhuma 
qui n'a aucune réalité scientifique. Souvent les personnes superficielles se laissent éblouir par cette apparence de logique, et c'est ainsi que se renouvellent parfois de nos jours des discussions dignes de l'ancienne scolastique. Cette foi trop grande dans le raisonnement, qui conduit un physiologiste à une fausse simplification des choses, tient d'une part à l'ignorance de la science dont il parle, et d'autre part à l'absence du sentiment de complexité des phénomènes naturels. C'est pourquoi nous voyons quelquefois des mathématiciens purs, très grands esprits d'ailleurs, tomber dans des erreurs de ce genre; ils simplifient trop et raisonnent sur les phénomènes tels qu'il les font dans leur esprit, mais non tels qu'ils sont dans la nature.

Le grand principe expérimental est donc le doute, le doute philosophique qui-laisse à l'esprit sa liberté et son initiative, et d'où dérivent les qualités les plus précieuses pour un investigateur en physiologie et en médecine. II ne faut croire à nos observations, à nos théories que sous bénéfice d'inventaire expérimental. Si l'on croit trop, l'esprit se trouve lié et rétréci par les conséquences, de son propre raisonnement ; il n'a plus de liberté d'action et manque par suite de l'initiative que possède celui qui sait se dégager de cette foi aveugle dans les théories, qui n'est au fond qu'une superstition scientifique.

On a souvent dit que, pour faire des découvertes, il fallait être ignorant. Cette opinion fausse en elle-même cache cependant une vérité. Elle signifie qu'il vaut mieux ne rien savoir que d'avoir dans l'esprit des idées fixes appuyées sur des théories dont on cherche toujours la confirmation en négligeant tout ce qui ne s'y rapporte pas. Cette disposition d'esprit est des plus realidade científica. Frequentemente as pessoas superficiais se deixam impressionar por essa aparência de lógica e é assim que às vezes se renovam nos dias de hoje discussões dignas da antiga escolástica. Esta fé demasiadamente grande no raciocínio, que conduz um fisiologista a uma falsa simplificação das coisas, se deve, por um lado, à ignorância da ciência da qual ele fala e, por outro, à ausência do sentimento de complexidade dos fenômenos naturais. É por isso que vemos algumas vezes matemáticos puros, grandes espíritos aliás, caírem em erros desse tipo; eles simplificam demais e raciocinam sobre os fenômenos da forma como o fazem em seu espírito, mas não da forma como são na natureza.

O grande princípio experimental é, portanto, a dúvida, a dúvida filosófica que permite ao espírito sua liberdade e sua iniciativa e de onde derivam as qualidades mais preciosas para um investigador em fisiologia e em medicina. Não é preciso crer em nossas observações, em nossas teorias, senão sob o benefício de inventário experimental. Se se crê demais, o espírito permanece atado e limitado pelas consequências de seu próprio raciocínio; não há mais liberdade de ação e falta, consequentemente, a iniciativa que possui aquele que sabe se desvencilhar dessa fé cega nas teorias, que não é, no fundo, senão uma superstição científica.

Já se disse frequentemente que, para fazer descobertas, era preciso ser ignorante. Essa opinião, falsa em si mesma, esconde, no entanto, uma verdade. Ela significa que mais vale não saber nada do que ter no espírito ideias fixas apoiadas em teorias das quais ainda se busca a confirmação, negligenciando tudo aquilo que não se refira a elas. Essa disposição de espírito é uma das 
mauvaises, et elle est éminemment opposée à l'invention. En effet, une découverte est en général un rapport imprévu qui ne se trouve pas compris dans la théorie, car sans cela il serait prévu. Un homme ignorant, qui ne connaîtrait pas la théorie, serait, en effet, sous ce rapport, dans de meilleures conditions d'esprit ; la théorie ne le gênerait pas et ne l'empêcherait pas de voir des faits nouveaux que n'aperçoit pas celui qui est préoccupé d'une théorie exclusive. Mais hâtons-nous de dire qu'il ne s'agit point ici d'élever l'ignorance en principe. Plus on est instruit, plus on possède de connaissances antérieures, mieux on aura l'esprit disposé pour faire des. découvertes grandes et fécondes. Seulement il faut garder sa liberté d'esprit, ainsi que nous l'avons dit plus haut, et croire que dans la nature l'absurde suivant nos théories n'est pas toujours impossible.

Les hommes qui ont une foi excessive dans leurs théories ou dans leurs idées sont non seulement mal disposés pour faire des découvertes, mais ils font aussi de très mauvaises observations. Ils observent nécessairement avec une idée préconçue, et quand ils ont institué une expérience, ils ne veulent voir dans ses résultats qu'une confirmation de leur théorie. Ils défigurent ainsi l'observation et négligent souvent des faits très importants, parce qu'ils ne concourent pas à leur but. C'est ce qui nous a fait dire ailleurs qu'il ne fallait jamais faire des expériences pour confirmer ses idées, mais simplement pour les contrôler; ce qui signifie, en d'autres termes, qu'il faut accepter les résultats de l'expérience tels qu'ils se présentent, avec tout leur imprévu et leurs accidents. piores e ela é eminentemente oposta à invenção. De fato, uma descoberta é, em geral, uma relação imprevista que não está contida na teoria, porque, caso contrário, ela seria prevista. Um homem ignorante, que não conhecesse a teoria, estaria, na verdade, nesse caso, em melhores condições de espírito; a teoria não o incomodaria e não o impediria de ver os fatos novos que não percebe aquele que está preocupado com uma teoria exclusiva. Mas, apressemo-nos em dizer que não se trata aqui de enaltecer a ignorância como princípio. Quanto mais se é instruído, mais se possui conhecimentos anteriores, mais disposto será o espírito para fazer descobertas grandes e fecundas. Apenas é preciso conservar sua liberdade de espírito, assim como já dissemos, e acreditar que na natureza o absurdo que decorre de nossas teorias nem sempre é impossível.

Os homens que têm uma fé excessiva em suas teorias ou em suas ideias são não apenas mal preparados para fazer descobertas, mas eles também fazem observações muito ruins. Eles observam obrigatoriamente com uma ideia préconcebida e quando fazem uma experiência, eles só querem ver em seus resultados uma confirmação de sua teoria. Eles desfiguram assim a observação e negligenciam frequentemente fatos muito importantes, porque eles não se alinham ao seu objetivo. Foi isso que nos fez dizer alhures que nunca era preciso fazer experiências para confirmar as ideias, mas simplesmente para controlá-las ${ }^{89}$; o que significa, em outros termos, que é preciso aceitar os resultados da experiência tal como se apresentam, com todo seu imprevisto e seus acidentes.

\footnotetext{
${ }^{89}$ Leçons sur les propriétés et les altérations des liquides de l'organisme. Paris, 1859. 1re leçon.
} 
Mais il arrive encore tout naturellement que ceux qui croient trop à leurs théories ne croient pas assez à celles des autres. Alors l'idée dominante de ces contempteurs d'autrui est de trouver les théories des autres en défaut et de chercher à les contredire. L'inconvénient pour la science reste le même. Ils ne font des expériences que pour détruire une théorie, au lieu de les faire pour chercher la vérité. Ils font également de mauvaises observations parce qu'ils ne prennent dans les résultats de leurs expériences que ce qui convient à leur but en négligeant ce qui ne s'y rapporte pas, et en écartant bien soigneusement tout ce qui pourrait aller dans le sens de l'idée qu'ils veulent combattre. On est donc conduit ainsi par ces deux voies opposées au même résultat, c'est-à-dire à fausser la science et les faits.

La conclusion de tout ceci est qu'il faut effacer son opinion aussi bien que celle des autres devant les décisions de l'expérience. Quand on discute et que l'on expérimente comme nous venons de le dire, pour prouver quand même une idée préconçue, on n'a plus l'esprit libre et l'on ne cherche plus la vérité. On fait de la science étroite à laquelle se mêlent la vanité personnelle ou les diverses passions humaines. L'amourpropre, cependant, ne devrait rien avoir à faire dans toutes ces vaines disputes. Quand deux physiologistes ou deux médecins se querellent pour soutenir chacun leurs idées ou leurs théories, il n'y a au milieu de leurs arguments contradictoires qu'une seule chose qui soit absolument certaine : c'est que les deux théories sont insuffisantes et ne représentent la vérité ni l'une ni l'autre. L'esprit vraiment scientifique devrait donc nous rendre modestes et bienveillants. Nous savons tous bien peu de chose en réalité, et nous sommes tous faillibles en face des
Mas ainda acontece, de forma muito natural, que aqueles que acreditam demais em suas teorias não creem o suficiente nas dos outros. Então, a ideia dominante desses detratores do outro é a de encontrar defeitos nas teorias dos outros e procurar contradizê-las. $\mathrm{O}$ inconveniente para a ciência continua o mesmo. Eles só fazem experiências para destruir uma teoria, em vez de fazê-las para buscar a verdade. Eles também fazem observações ruins porque eles tiram dos resultados de suas experiências apenas o que convém a seu objetivo, negligenciando aquilo que não se refira a ele e descartando de forma bem cuidadosa tudo aquilo que poderia conduzir na direção do sentido da ideia que eles querem combater. Assim se é conduzido por essas duas vias opostas ao mesmo resultado, isto é, o de falsear a ciência e os fatos.

A conclusão de tudo isto é que é preciso abrir mão da própria opinião, assim como da dos outros, diante das decisões da experiência. Quando se discute e se experimenta, como acabamos de dizer, para provar uma ideia, mesmo que pré-concebida, não se tem mais o espírito livre e não se procura mais a verdade. Faz-se a ciência estreita, à qual se misturam a vaidade pessoal ou as diversas paixões humanas. 0 amor próprio, entretanto, não deveria ter nada a fazer em todas estas vãs disputas. Quando dois fisiologistas ou dois médicos lutam para sustentar cada um suas ideias ou suas teorias, no meio de seus argumentos contraditórios, somente uma coisa é absolutamente certa: é que as duas teorias são insuficientes e nenhuma das duas representa a verdade. 0 espírito verdadeiramente científico deveria, portanto, nos tornar modestos e benevolentes. Todos nós sabemos bem algumas poucas coisas, na verdade, e todos 
difficultés immenses que nous offre l'investigation dans les phénomènes naturels. Nous n'aurions donc rien de mieux à faire que de réunir nos efforts au lieu de les diviser et de les neutraliser par des disputes personnelles. En un mot, le savant qui veut trouver la vérité doit conserver son esprit libre, calme, et, si c'était possible, ne jamais avoir, comme dit Bacon, l'œil humecté par les passions humaines.

Dans l'éducation scientifique, il importerait beaucoup de distinguer, ainsi que nous le ferons plus loin, le déterminisme qui est le principe absolu de la science d'avec les théories qui ne sont que des principes relatifs auxquels on ne doit accorder qu'une valeur provisoire dans la recherche de la vérité. En un mot il ne faut point enseigner les théories comme des dogmes ou des articles de foi. Par cette croyance exagérée dans les théories, on donnerait une idée fausse de la science, on surchargerait et l'on asservirait l'esprit en lui enlevant sa liberté et étouffant son originalité, et en lui donnant le goût des systèmes.

Les théories qui représentent l'ensemble de nos idées scientifiques sont sans doute indispensables pour représenter la science. Elles doivent aussi servir de point d'appui à des idées investigatrices nouvelles. Mais ces théories et ces idées n'étant point la vérité immuable, il faut être toujours prêt à les abandonner, à les modifier ou à les changer dès qu'elles ne représentent plus la réalité. En un mot, il faut modifier la théorie pour l'adapter à la nature, et non la nature pour l'adapter à la théorie. nós somos falíveis diante das dificuldades imensas que nos apresenta a investigação dos fenômenos naturais. Não teríamos, portanto, nada melhor a fazer senão reunir nossos esforços em vez de dividi-los e de neutralizá-los por disputas pessoais. Em uma palavra, o estudioso que quer encontrar a verdade deve conservar seu espírito livre, calmo e, se possível, jamais ter, como diz Bacon, o olho embaciado pelas paixões humanas.

$\mathrm{Na}$ educação científica, seria muito importante distinguir, assim como faremos mais adiante, o determinismo, que é o princípio absoluto da ciência, das teorias que não são senão princípios relativos aos quais se deve atribuir apenas um valor provisório na busca da verdade. Em uma palavra, não é preciso, de forma alguma, ensinar as teorias como dogmas ou artigos de fé. Por essa crença exagerada nas teorias, dar-se-ia uma falsa ideia da ciência, se sobrecarregaria e se escravizaria o espírito, tirando-lhe a liberdade e sufocando sua originalidade, dando-Ihe o gosto dos sistemas.

As teorias que representam o conjunto de nossas ideias científicas são provavelmente indispensáveis para representar a ciência. Elas também devem servir de ponto de apoio para novas ideias investigativas. Mas não sendo essas teorias e essas ideias de forma alguma a verdade imutável, é preciso estar sempre pronto para abandoná-las, modificá-las ou trocá-las, a partir do momento que não representarem mais a realidade. Em uma palavra, é preciso modificar a teoria para adaptá-la à natureza e não a natureza para adaptá-la à teoria.

Resumindo, há duas coisas a considerar na ciência experimental: o método e a ideia. 0 
et l'idée. La méthode a pour objet de diriger l'idée qui s'élance en avant dans l'interprétation des phénomènes naturels et dans la recherche de la vérité. L'idée doit toujours rester indépendante, et il ne faut point l'enchaîner, pas plus par des croyances scientifiques que par des croyances philosophiques ou religieuses; il faut être hardi et libre dans la manifestation de ses idées, suivre son sentiment et ne point trop s'arrêter à ces craintes puériles de la contradiction des théories. Si l'on est bien imbu des principes de la méthode expérimentale, on n'a rien à craindre ; car, tant que l'idée est juste, on continue à la développer ; quand elle est erronée, l'expérience est là pour la rectifier. II faut donc savoir trancher les questions, même au risque d'errer. On rend plus de service à la science, a-t-on dit, par l'erreur que par la confusion, ce qui signifie qu'il faut pousser sans crainte les idées dans tout leur développement pourvu qu'on les règle et que I'on ait toujours soin de les juger par l'expérience. L'idée, en un mot, est le mobile de tout raisonnement en science comme ailleurs. Mais partout l'idée doit être soumise à un critérium. En science, ce critérium est la méthode expérimentale ou l'expérience, ce critérium est indispensable, et nous devons l'appliquer à nos propres idées comme à celles des autres. método tem por objeto guiar a ideia que se projeta à frente na interpretação dos fenômenos naturais e na busca da verdade. A ideia deve se manter sempre independente e não é preciso mais, de forma alguma, vinculá-la a crenças científicas nem a crenças filosóficas ou religiosas; é preciso ser audacioso e livre na manifestação de suas ideias, seguir seu sentimento e jamais se fixar a essas crenças pueris da contradição das teorias. Se se está bem imbuído desses princípios do método experimental, não se tem nada a temer; pois, enquanto a ideia for precisa, continua-se a desenvolvê-la; quando ela for errônea, a experiência estará lá para retificá-la. É preciso, portanto, saber resolver as questões, mesmo com o risco de errar. Faz-se maior favor à ciência, como se diz, pelo erro que pela confusão, o que significa que é preciso conduzir sem medo as ideias em todo o seu desenvolvimento, desde que elas sejam reguladas e que se tenha o cuidado de julgá-las pela experiência. A ideia, em resumo, é o motor de todo raciocínio tanto em ciência como fora dela. Mas a ideia sempre deve ser submetida a um critério. Em ciência, esse critério é o método experimental ou a experiência, esse critério é indispensável e nós devemos aplicá-lo a nossas próprias ideias assim como às dos outros.

\begin{tabular}{|c|c|}
\hline $\begin{array}{l}\text { IV } \\
\text { Caractère indépendant } \\
\text { de la méthode expérimentale }\end{array}$ & $\begin{array}{l}\text { IV } \\
\text { Caráter independente } \\
\text { do método experimental }\end{array}$ \\
\hline $\begin{array}{l}\text { De tout ce qui a été dit précédemment il } \\
\text { résulte nécessairement que l'opinion } \\
\text { d'aucun homme, formulée en théorie ou } \\
\text { autrement, ne saurait être considérée } \\
\text { comme représentant la vérité complète }\end{array}$ & $\begin{array}{l}\text { De tudo o que foi dito anteriormente resulta } \\
\text { necessariamente que a opinião de nenhum } \\
\text { homem, formulada em teoria ou de outra } \\
\text { maneira, poderia ser considerada como } \\
\text { representando a verdade completa nas }\end{array}$ \\
\hline
\end{tabular}




\begin{tabular}{|c|c|}
\hline $\begin{array}{l}\text { dans les sciences. C'est un guide, une } \\
\text { lumière, mais non une autorité absolue. La } \\
\text { révolution que la méthode expérimentale a } \\
\text { opérée dans les sciences consiste à avoir } \\
\text { substitué un critérium scientifique à } \\
\text { l'autorité personnelle. }\end{array}$ & $\begin{array}{l}\text { ciências. É um guia, uma luz, mas não uma } \\
\text { autoridade absoluta. A revolução que o } \\
\text { método experimental operou nas ciências } \\
\text { consiste em ter substituído a autoridade } \\
\text { pessoal por um critério científico. }\end{array}$ \\
\hline $\begin{array}{l}\text { Le caractère de la méthode expérimentale } \\
\text { est de ne relever que d'elle même, parce } \\
\text { qu'elle renferme en elle son critérium, qui } \\
\text { est l'expérience. Elle ne reconnaît d'autre } \\
\text { autorité que celle des faits, et elle } \\
\text { s'affranchit de l'autorité personnelle. Quand } \\
\text { Descartes disait qu'il faut, ne s'en rapporter } \\
\text { qu'à l'évidence ou à ce qui est suffisamment } \\
\text { démontré, cela signifiait qu'il fallait ne plus } \\
\text { s'en référer à l'autorité, comme faisait la } \\
\text { scolastique, mais ne s'appuyer que sur les } \\
\text { faits bien établis par l'expérience. }\end{array}$ & $\begin{array}{l}\text { A característica do método experimental é } \\
\text { de só depender dele mesmo, porque encerra } \\
\text { em si mesmo seu critério, que é a } \\
\text { experiência. Ele não reconhece outra } \\
\text { autoridade a não ser a dos fatos e ele se } \\
\text { liberta da autoridade pessoal. Quando } \\
\text { Descartes dizia que é preciso submeter-se } \\
\text { apenas à evidência ou ao que está } \\
\text { suficientemente demonstrado, isso } \\
\text { significava que era preciso não se submeter } \\
\text { mais à autoridade, como fazia a escolástica, } \\
\text { mas apoiar-se apenas nos fatos bem } \\
\text { estabelecidos pela experiência. }\end{array}$ \\
\hline $\begin{array}{l}\text { De là il résulte que, lorsque dans la science } \\
\text { nous avons émis une idée ou une théorie, } \\
\text { nous ne devons pas avoir pour but de la } \\
\text { conserver en cherchant tout ce qui peut } \\
\text { l'appuyer et en écartant tout ce qui peut } \\
\text { l'infirmer. Nous devons, au contraire, } \\
\text { examiner avec le plus grand soin les faits qui } \\
\text { semblent la renverser, parce que le progrès } \\
\text { réel consiste toujours à changer une théorie } \\
\text { ancienne qui renferme moins de faits contre } \\
\text { une nouvelle qui en renferme davantage. } \\
\text { Cela prouve que l'on a marché, car en } \\
\text { science le grand précepte est de modifier et } \\
\text { de changer ses idées à mesure que la science } \\
\text { avance. Nos idées ne sont que des } \\
\text { instruments intellectuels qui nous servent à } \\
\text { pénétrer dans les phénomènes; il faut les } \\
\text { changer quand elles ont rempli leur rôle, } \\
\text { comme on change un bistouri émoussé } \\
\text { quand il a servi assez longtemps. }\end{array}$ & $\begin{array}{l}\text { Disso resulta que, quando emitimos uma } \\
\text { ideia ou uma teoria na ciência, não devemos } \\
\text { ter o objetivo de conservá-la, procurando } \\
\text { tudo o que pode apoiá-la e descartando tudo } \\
\text { o que pode invalidá-la. Devemos, ao } \\
\text { contrário, examinar com o maior cuidado os } \\
\text { fatos que parecem abalá-la, porque o } \\
\text { progresso real consiste em sempre mudar } \\
\text { uma teoria antiga, que encerra menos fatos, } \\
\text { por uma nova, que encerra mais. Isso prova } \\
\text { que se progrediu, pois, em ciência, o grande } \\
\text { preceito é modificar e mudar suas ideias à } \\
\text { medida que a ciência avança. Nossas ideias } \\
\text { são apenas instrumentos intelectuais que } \\
\text { nos servem para penetrar nos fenômenos; é } \\
\text { preciso mudá-las quando elas já } \\
\text { desempenharam seu papel, como se } \\
\text { substitui um bisturi gasto quando ele já foi } \\
\text { usado por muito tempo. }\end{array}$ \\
\hline
\end{tabular}




\begin{abstract}
Les idées et les théories de nos prédécesseurs ne doivent être conservées qu'autant qu'elles représentent l'état de la science, mais elles sont évidemment destinées à changer, à moins que l'on admette que la science ne doive plus faire de progrès, ce qui est impossible. Sous ce rapport, il y aurait peut-être une distinction à établir entre les sciences mathématiques et les sciences expérimentales. Les vérités mathématiques étant immuables et absolues, la science s'accroît par juxtaposition simple et successive de toutes les vérités acquises. Dans les sciences expérimentales, au contraire, les vérités n'étant que relatives, la science ne peut avancer que par révolution et par absorption des vérités anciennes dans une forme scientifique nouvelle.
\end{abstract}

Dans les sciences expérimentales, le respect mal entendu de l'autorité personnelle serait de la superstition et constituerait un véritable obstacle aux progrès de la science ; ce serait en même temps contraire aux exemples que nous ont donnés les grands hommes de tous les temps. En effet, les grands hommes sont précisément ceux qui ont apporté des idées nouvelles et détruit des erreurs. Ils n'ont donc pas respecté euxmêmes l'autorité de leurs prédécesseurs, et ils n'entendent pas qu'on agisse autrement envers eux.

Cette non-soumission à l'autorité, que la méthode expérimentale consacre comme un précepte fondamental, n'est nullement en désaccord avec le respect et l'admiration que nous vouons aux grands hommes qui nous ont précédés et auxquels nous devons les découvertes qui sont les bases des sciences actuelles.
As ideias e as teorias de nossos predecessores não devem ser mantidas a não ser que elas representem o estado da ciência, mas elas são evidentemente destinadas a mudar, a menos que se admita que a ciência não deva mais fazer progressos, o que é impossível. Sob esse aspecto, haveria talvez uma distinção a estabelecer entre as ciências matemáticas e as ciências experimentais. Sendo as verdades matemáticas imutáveis e absolutas, a ciência cresce por justaposição simples e sucessiva de todas as verdades adquiridas. Nas ciências experimentais, ao contrário, as verdades sendo apenas relativas, a ciência só pode avançar pela revolução e pela absorção das antigas verdades em uma nova forma científica.

Nas ciências experimentais, o respeito mal compreendido à autoridade pessoal seria superstição e constituiria um verdadeiro obstáculo aos progressos da ciência; seria ao mesmo tempo contrário aos exemplos que nos deram os grandes homens de todos os tempos. De fato, os grandes homens são justamente aqueles que trouxeram ideias novas e derrubaram equívocos. Eles próprios não respeitaram, portanto, a autoridade de seus predecessores e não concebem que se possa agir de outra forma em relação a eles.

Esta não submissão à autoridade, que o método experimental consagra como um preceito fundamental, não está de forma alguma em desacordo com o respeito e admiração que nutrimos pelos grandes homens que nos precederam e aos quais devemos as descobertas que são as bases das ciências atuais. ${ }^{90}$

\footnotetext{
${ }^{90}$ Ver Cours de médecine expérimentale; leçon d'ouverture. Gazette méd., 15 avril 1864.
} 
Dans les sciences expérimentales les grands hommes ne sont jamais les promoteurs de vérités absolues et immuables. Chaque grand homme tient à son temps et ne peut venir qu'à son moment, en ce sens qu'il y a une succession nécessaire et subordonnée dans l'apparition des découvertes scientifiques. Les grands hommes peuvent être comparés à des flambeaux qui brillent de loin en loin pour guider la marche de la science. Ils éclairent leur temps, soit en découvrant des phénomènes imprévus et féconds qui ouvrent des voies nouvelles et montrent des horizons inconnus, soit en généralisant les faits scientifiques acquis et en en faisant sortir des vérités que leurs devanciers n'avaient point aperçues. Si chaque grand homme fait accomplir un grand pas à la science qu'il féconde, il n'a jamais eu la prétention d'en poser les dernières limites, et il est nécessairement destiné à être dépassé et laissé en arrière par les progrès des générations qui suivront. Les grands hommes ont été comparés à des géants sur les épaules desquels sont montés des pygmées, qui cependant voient plus loin qu'eux. Ceci veut dire simplement que les sciences font des progrès après ces grands hommes et précisément à cause de leur influence. D'où il résulte que leurs successeurs auront des connaissances scientifiques acquises plus nombreuses que celles que ces grands hommes possédaient de leur temps. Mais le grand homme n'en reste pas moins le grand homme, c'est-àdire le géant.

Il y a, en effet, deux parties dans les sciences en évolution; il y a d'une part ce qui est acquis et d'autre part ce qui reste à acquérir. Dans ce qui est acquis, tous les hommes se valent à peu près, et les grands ne sauraient se distinguer des autres. Souvent même les
Nas ciências experimentais, os grandes homens jamais são os promotores de verdades absolutas e imutáveis. Cada grande homem está preso a seu tempo e só pode surgir no seu momento, no sentido de que existe uma sucessão necessária e subordinada ao aparecimento das descobertas científicas. Os grandes homens podem ser comparados a chamas que brilham gradativamente mais longe para guiar a marcha da ciência. Eles clareiam seu tempo, seja descobrindo fenômenos imprevistos e fecundos que abrem novas vias e mostram horizontes desconhecidos, seja generalizando os fatos científicos adquiridos e deles tirando verdades que seus antecessores não tinham percebido. Se cada grande homem acrescenta um grande passo à ciência que ele fecunda, ele nunca teve a pretensão de nela colocar os últimos limites e ele está necessariamente destinado a ser ultrapassado e deixado para trás pelos progressos das gerações que virão a seguir. Os grandes homens foram comparados a gigantes, sobre os ombros dos quais subiram pigmeus que, no entanto, enxergam mais longe que eles. Isto quer simplesmente dizer que as ciências fazem progressos após a passagem desses grandes homens e precisamente graças à sua influência. Como consequência, seus sucessores adquirirão conhecimentos científicos mais numerosos que os que esses grandes homens possuíam em seu tempo. Mas o grande homem não deixa por isso de ser o grande homem, ou seja, o gigante.

Existem, de fato, duas vertentes nas ciências em evolução; de um lado, existe o que é adquirido e, de outro, o que resta a adquirir. Em relação ao que é adquirido, todos os homens se valem de certa forma e os grandes não poderiam distinguir-se dos 
hommes médiocres sont ceux qui possèdent le plus de connaissances acquises. C'est dans les parties obscures de la science que le grand homme se reconnaît ; il se caractérise par des idées de génie qui illuminent des phénomènes restés obscurs et portent la science en avant.

En résumé, la méthode expérimentale puise en elle-même une autorité impersonnelle qui domine la science. Elle l'impose même aux grands hommes au lieu de chercher comme les scolastiques à prouver par les textes qu'ils sont infaillibles et qu'ils ont vu, dit ou pensé tout ce qu'on a découvert après eux. Chaque temps a sa somme d'erreurs et de vérités. II y a des erreurs qui sont en quelque sorte inhérentes à leur temps, et que les progrès ultérieurs de la science peuvent seuls faire reconnaître. Les progrès de la méthode expérimentale consistent en ce que la somme des vérités augmente à mesure que la somme des erreurs diminue. Mais chacune de ces vérités particulières s'ajoute aux autres pour constituer des vérités plus générales. Les noms des promoteurs de la science disparaissent peu à peu dans cette fusion, et plus la science avance, plus elle prend la forme impersonnelle et se détache du passé. Je me hâte d'ajouter, pour éviter une confusion qui a parfois été commise, que je n'entends parler ici que de l'évolution de la science. Pour les arts et les lettres, la personnalité domine tout. II s'agit là d'une création spontanée de l'esprit, et cela n'a plus rien de commun avec la constatation des phénomènes naturels, dans lesquels notre esprit ne doit rien créer. Le passé conserve toute sa valeur dans ces créations des arts et des lettres; chaque individualité reste immuable dans le temps et ne peut se confondre avec les autres. Un poète contemporain a caractérisé ce sentiment de outros. Acontece até mesmo de os homens medíocres serem aqueles que mais possuem conhecimentos adquiridos. É nas partes obscuras da ciência que o grande homem se reconhece; ele se caracteriza por ideias geniais que iluminam fenômenos ainda obscuros e que levam a ciência adiante.

Resumindo, o método experimental empresta a si mesmo uma autoridade impessoal que domina a ciência. Ele a impõe até aos grandes homens, em vez de, como os escolásticos, tentar provar pelos textos que eles são infalíveis e que eles viram, disseram ou pensaram tudo aquilo que se descobriu depois deles. Cada época tem sua soma de erros e de verdades. Há erros que são de alguma forma inerentes a seu tempo e que somente os próprios progressos ulteriores da ciência podem reconhecer. Os progressos do método experimental consistem no fato de que a soma das verdades aumenta à medida que a soma dos erros diminui. Mas cada uma dessas verdades particulares se acrescenta às outras para constituir verdades mais gerais. Os nomes dos promotores da ciência desaparecem pouco a pouco nessa fusão e quanto mais a ciência avança, mais ela toma a forma impessoal e se desvencilha do passado. Eu me apresso a acrescentar, para evitar um equívoco que foi frequentemente cometido, que eu me limito aqui a falar da evolução da ciência. Para as artes e as letras, a personalidade domina tudo. Trata-se neste caso de uma criação espontânea do espírito, e isso não tem nada em comum com a constatação dos fenômenos naturais, para os quais nosso espírito não deve criar nada. O passado conserva todo o seu valor nessas criações das artes e das letras; cada individualidade permanece imutável no tempo e não pode se confundir com as outras. Um poeta contemporâneo caracterizou este 


\begin{abstract}
la personnalité de l'art et de l'impersonnalité de la science par ces mots : l'art, c'est moi ; la science, c'est nous.

La méthode expérimentale est la méthode scientifique qui proclame la liberté de l'esprit et de la pensée. Elle secoue non seulement le joug philosophique et théologique, mais elle n'admet pas non plus d'autorité scientifique personnelle. Ceci n'est point de l'orgueil et de la jactance ; l'expérimentateur, au contraire, fait acte d'humilité en niant l'autorité personnelle, car il doute aussi de ses propres connaissances, et il soumet l'autorité des hommes à celle de l'expérience et des lois de la nature.
\end{abstract}

La physique et la chimie étant des sciences constituées, nous présentent cette indépendance et cette impersonnalité que réclame la méthode expérimentale. Mais la médecine est enclore dans les ténèbres de l'empirisme, et elle subit les conséquences de son état arriéré. On la voit encore plus ou moins mêlée à la religion et au surnaturel. Le merveilleux et la superstition y jouent un grand rôle. Les sorciers, les somnambules, les guérisseurs en vertu d'un don du ciel, sont écoutés à l'égal des médecins. La personnalité médicale est placée au-dessus de la science par les médecins eux-mêmes, ils cherchent leurs autorités dans la tradition, dans les doctrines, ou dans le tact médical. Cet état de choses est la preuve la plus claire que la méthode expérimentale n'est point encore arrivée dans la médecine.

La méthode expérimentale, méthode du libre penseur, ne cherche que la vérité scientifique. Le sentiment, d'où tout émane, doit conserver sa spontanéité entière et toute sa liberté pour la manifestation des idées expérimentales; la raison doit, elle sentimento da personalidade da arte e da impessoalidade da ciência por meio destas palavras: a arte sou eu; a ciência, somos nós.

O método experimental é o método científico que proclama a liberdade do espírito e do pensamento. Ele revoluciona não apenas o jugo filosófico e teológico, mas ele também não admite autoridade científica pessoal. Não se trata de orgulho e de arrogância; o experimentador, pelo contrário, faz ato de humildade ao negar a autoridade pessoal, pois ele duvida também de seus próprios conhecimentos e ele submete a autoridade dos homens à autoridade da experiência e das leis da natureza.

A física e a química, sendo ciências constituídas, nos apresentam essa independência e essa impessoalidade que o método experimental reclama. Mas a medicina é fechada nas trevas do empirismo e ela sofre as consequências de seu estado atrasado. Ela ainda é vista mais ou menos mesclada à religião e ao sobrenatural. 0 fantástico e a superstição desempenham aí um grande papel. Os feiticeiros, os videntes, os curandeiros, em virtude de um dom celeste, são ouvidos da mesma forma que os médicos. A personalidade médica é colocada acima da ciência pelos próprios médicos, que buscam sua autoridade na tradição, nas doutrinas ou no tato médico. Este estado de coisas é a prova mais clara de que o método experimental ainda não chegou na medicina.

O método experimental, método do livre pensador, busca somente a verdade científica. O sentimento, de onde tudo emana, deve conservar toda a sua espontaneidade e toda a sua liberdade para manifestar ideias experimentais; a razão 
aussi, conserver la liberté de douter, et par cela elle s'impose de soumettre toujours I'idée au contrôle de l'expérience. De même que dans les autres actes humains, le sentiment détermine à agir en manifestant l'idée qui donne le motif de l'action, de même dans la méthode expérimentale, c'est le sentiment qui a l'initiative par l'idée. C'est le sentiment seul qui dirige l'esprit et qui constitue le primum movens de la science. Le génie se traduit par un sentiment délicat qui pressent d'une manière juste les lois des phénomènes de la nature ; mais, ce qu'il ne faut jamais oublier, c'est que la justesse du sentiment et la fécondité de l'idée ne peuvent être établies et prouvées que par l'expérience. deve, ela também, conservar a liberdade de duvidar e, assim, ela se encarrega de sempre submeter a ideia ao controle da experiência. Como nos outros atos humanos, o sentimento leva a agir, manifestando a ideia que motiva a ação; da mesma forma, também no método experimental é o sentimento que tem a iniciativa pela ideia. É o sentimento sozinho que guia o espírito e que constitui o primum movens da ciência. $O$ gênio se traduz por um sentimento delicado que pressente de uma maneira exata as leis dos fenômenos da natureza; mas, o que não se deve jamais esquecer é que a exatidão do sentimento e a fecundidade da ideia só podem ser estabelecidas e provadas pela experiência.

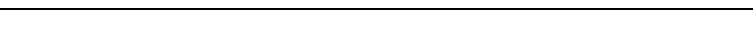

\begin{tabular}{l|l}
\hline V & V
\end{tabular} \\ De l'induction et de la déduction dans le raisonnement expérimental}

Après avoir traité dans tout ce qui précède de l'influence de l'idée expérimentale, examinons actuellement comment la méthode doit, en imposant toujours au raisonnement la forme dubitative, le diriger d'une manière plus sûre dans la recherche de la vérité.

Nous avons dit ailleurs que le raisonnement expérimental s'exerce sur des phénomènes observés, c'est-à-dire sur des observations ; mais, en réalité, il ne s'applique qu'aux idées que l'aspect de ces phénomènes a éveillées en notre esprit. Le principe du raisonnement expérimental sera donc toujours une idée qu'il s'agit d'introduire dans un raisonnement expérimental pour la soumettre au critérium des faits, c'est-à-dire à l'expérience.

\section{V}

Da indução e da dedução no raciocínio experimental.

Após ter tratado em tudo o que já se expôs da influência da ideia experimental, examinemos agora como o método deve, impondo sempre ao raciocínio a forma dubitativa, guiá-lo de uma maneira mais segura na busca da verdade.

Dissemos alhures que o raciocínio experimental se exerce sobre os fenômenos observados, isto é, sobre observações; mas, na realidade, ele só se aplica às ideias que o aspecto de tais fenômenos despertou em nosso espírito. O princípio do raciocínio experimental, portanto, será sempre uma ideia que se deve introduzir num raciocínio experimental para submetê-la ao critério dos fatos, isto é, à experiência. 
Il y a deux formes de raisonnement : $1^{\circ}$ la forme investigative ou interrogative qu'emploie l'homme qui ne sait pas et qui veut $s^{\prime}$ instruire ; $2^{\circ}$ la forme démonstrative ou affirmative qu'emploie l'homme qui sait ou croit savoir, et qui veut instruire les autres.

Les philosophes paraissent avoir distingué ces deux formes de raisonnement sous les noms de raisonnement inductif et de raisonnement déductif. Ils ont encore admis deux méthodes scientifiques, la méthode inductive ou l'induction, propre aux sciences physiques expérimentales, et la méthode déductive ou la déduction, appartenant plus spécialement aux sciences mathématiques.

II résulterait de là que la forme spéciale du raisonnement expérimental dont nous devons seulement nous occuper ici serait l'induction.

On définit l'induction en disant que c'est un procédé de l'esprit qui va du particulier au général, tandis que la déduction serait le procédé inverse qui irait du général au particulier. Je n'ai certainement pas la prétention d'entrer dans une discussion philosophique qui serait ici hors de sa place et de ma compétence ; seulement, en qualité 'expérimentateur, je me bornerai à dire que dans la pratique il me paraît bien difficile de justifier cette distinction et de séparer nettement l'induction de la déduction. Si l'esprit de l'expérimentateur procède ordinairement en partant d'observations particulières pour remonter à des principes, à des lois ou à des propositions générales, il procède aussi nécessairement de ces mêmes propositions générales ou lois pour aller à des faits particuliers qu'il déduit logiquement de ces principes. Seulement quand la certitude du
Há duas formas de raciocínio: 10 a forma investigativa ou interrogativa que é empregada pelo homem que não sabe e que quer se instruir; 20 a forma demonstrativa ou afirmativa que é empregada pelo homem que sabe ou acredita saber e que quer ensinar os outros.

Os filósofos parecem ter distinguido essas duas formas de raciocínio pelos nomes de raciocínio indutivo e raciocínio dedutivo. Eles ainda admitiram dois métodos científicos, o método indutivo ou a indução, próprio das ciências físicas experimentais, e o método dedutivo ou a dedução, pertencente mais particularmente às ciências matemáticas.

Disso resultaria que a forma especial do raciocínio experimental, o único que devemos tratar aqui, seria somente $a$ indução.

Define-se a indução dizendo-se que é um procedimento do espírito que vai do particular ao geral, enquanto a dedução seria o procedimento inverso, que iria do geral ao particular. Eu certamente não tenho a pretensão de entrar numa discussão filosófica, que estaria aqui fora do seu lugar e de minha competência; apenas, na qualidade de experimentador, eu me limitarei a dizer que na prática me parece bem difícil justificar esta distinção e separar nitidamente a indução da dedução. Se o espírito do experimentador procede habitualmente partindo de observações particulares para chegar a princípios, leis ou proposições gerais, ele procede também necessariamente por essas mesmas proposições gerais ou leis para chegar a fatos particulares que ele deduz logicamente a partir desses princípios. Somente quando a certeza do princípio não é absoluta, trata-se 
principe n'est pas absolue, il s'agit toujours d'une déduction provisoire qui réclame la vérification expérimentale. Toutes les variétés apparentes du raisonnement ne tiennent qu'à la nature du sujet que l'on traite et à sa plus ou moins grande complexité. Mais, dans tous ces cas, l'esprit de l'homme fonctionne toujours de même par syllogisme; il ne pourrait pas se conduire autrement.

De même que dans la marche naturelle du corps, I'homme ne peut avancer qu'en posant un pied devant l'autre, de même dans la marche naturelle de l'esprit, I'homme ne peut avancer qu'en mettant une idée devant l'autre. Ce qui veut dire, en d'autres termes, qu'il faut toujours un premier point d'appui à l'esprit comme au corps. Le point d'appui du corps, c'est le sol dont le pied a la sensation; le point d'appui de l'esprit, c'est le connu, c'est-à-dire une vérité ou un principe dont l'esprit a conscience. L'homme ne peut rien apprendre qu'en allant du connu à l'inconnu ; mais, d'un autre côté, comme l'homme n'a pas en naissant la science infuse et qu'il ne sait rien que ce qu'il apprend, il semble que nous soyons dans un cercle vicieux et que I'homme soit condamné à ne pouvoir rien connaître. II en serait ainsi, en effet, si I'homme n'avait dans sa raison le sentiment des rapports et du déterminisme qui deviennent critérium de la vérité : mais, dans tous les cas, il ne peut obtenir cette vérité ou en approcher que par le raisonnement et par l'expérience.

D'abord il ne serait pas exact de dire que la déduction n'appartient qu'aux mathématiques et l'induction aux autres sciences exclusivement. Les deux formes de raisonnement investigatif (inductif) et démonstratif (déductif) appartiennent à sempre de uma dedução provisória que requer a verificação experimental. Todas as variações aparentes do raciocínio dependem somente da natureza do sujeito que é tratado e à sua maior ou menor complexidade. Mas, em todos esses casos, o espírito do homem continua funcionando por silogismo; ele não poderia proceder de outra forma.

Do mesmo modo que, na marcha natural do corpo, o homem não pode avançar senão colocando um pé diante do outro, na marcha natural do espírito, o homem não pode avançar senão colocando uma ideia diante de outra. O que quer dizer, em outros termos, que é preciso sempre um primeiro ponto de apoio tanto para o espírito quanto para o corpo. O ponto de apoio do corpo é o solo que é sentido pelo pé; o ponto de apoio do espírito é o conhecido, isto é, uma verdade ou um princípio de que o espírito tem consciência. O homem não pode aprender nada senão indo do conhecido ao desconhecido; mas, por outro lado, como o homem não tem a ciência inerente ao nascer e como ele sabe apenas o que ele aprende, parece que estamos num círculo vicioso e que o homem está condenado a não ser capaz de conhecer nada. Seria assim, de fato, se o homem não tivesse em sua razão o sentimento das relações e do determinismo que se tornam critério da verdade: mas, em todo os casos, ele não pode obter essa verdade ou dela se aproximar a não ser pelo raciocínio e pela experiência.

Primeiramente, não seria correto dizer que a dedução pertence apenas à matemática e a indução às outras ciências, exclusivamente. As duas formas de raciocínio investigativo (indutivo) e demonstrativo (dedutivo) pertencem a todas as ciências possíveis, 


\begin{tabular}{|c|c|}
\hline $\begin{array}{l}\text { toutes les sciences possibles, parce que dans } \\
\text { toutes les sciences il y a des choses qu'on ne } \\
\text { sait pas et d'autres qu'on sait ou qu'on croit } \\
\text { savoir. }\end{array}$ & $\begin{array}{l}\text { porque em todas as ciências existem coisas } \\
\text { que não se sabe e outras que se sabe ou se } \\
\text { acredita saber. }\end{array}$ \\
\hline $\begin{array}{l}\text { Quand les mathématiciens étudient des } \\
\text { sujets qu'ils ne connaissent pas, ils induisent } \\
\text { comme les physiciens, comme les chimistes } \\
\text { ou comme les physiologistes. Pour prouver } \\
\text { ce que j'avance, il suffira de citer les paroles } \\
\text { d'un grand mathématicien. }\end{array}$ & $\begin{array}{l}\text { Quando os matemáticos estudam os } \\
\text { assuntos que eles não conhecem, eles } \\
\text { induzem como os físicos, como os químicos } \\
\text { ou como os fisiologistas. Para provar o que } \\
\text { estou dizendo, bastará citar as palavras de } \\
\text { um grande matemático. }\end{array}$ \\
\hline $\begin{array}{l}\text { Voici comment Euler s'exprime dans un } \\
\text { mémoire intitulé : De inductione ad plenam } \\
\text { certitudinem evehenda: }\end{array}$ & $\begin{array}{l}\text { Eis como Euler }{ }^{91} \text { se expressa em uma } \\
\text { dissertação intitulada: De inductione ad } \\
\text { plenam certitudinem evehenda: }\end{array}$ \\
\hline $\begin{array}{l}\text { " Notum est plerumque numerum } \\
\text { proprietates primum per solam } \\
\text { inductionem observatas, quas dein ceps } \\
\text { geometroe solidis demonstrationibus } \\
\text { confirmare elaboraverunt; quo negotio in } \\
\text { primis Fermatius summo studio ET satis } \\
\text { felici successu fuit occupatus } 1 . "\end{array}$ & $\begin{array}{l}\text { "Notum est plerumque numerum } \\
\text { proprietates primum per solam inductionem } \\
\text { observatas, quas dein ceps geometroe } \\
\text { solidis demonstrationibus confirmare } \\
\text { elaboraverunt; quo negotio in primis } \\
\text { Fermatius summo studio ET satis felici } \\
\text { successu fuit occupatus }{ }^{92 . " 93}\end{array}$ \\
\hline $\begin{array}{l}\text { Les principes ou les théories qui servent de } \\
\text { base à une science, quelle qu'elle soit, ne } \\
\text { sont pas tombés du ciel ; il a fallu } \\
\text { nécessairement y arriver par un } \\
\text { raisonnement investigatif, inductif ou } \\
\text { interrogatif, comme on voudra l'appeler. Il a } \\
\text { fallu d'abord observer quelque chose qui se } \\
\text { soit passé au-dedans ou au-dehors de nous. } \\
\text { Dans les sciences, il y a, au point de vue } \\
\text { expérimental, des idées qu'on appelle a } \\
\text { priori parce qu'elles sont le point de départ } \\
\text { d'un raisonnement expérimental (voy. p. } 59\end{array}$ & $\begin{array}{l}\text { Os princípios ou as teorias que servem de } \\
\text { base a uma ciência, seja ela qual for, não } \\
\text { caem do céu; foi preciso chegar-se a ela } \\
\text { necessariamente por um raciocínio } \\
\text { investigativo, indutivo ou interrogativo, com } \\
\text { se queira chamar. Foi preciso inicialmente } \\
\text { observar alguma coisa que tinha acontecido } \\
\text { dentro ou fora de nós. Nas ciências, há, sob } \\
\text { o ponto de vista experimental, ideias } \\
\text { chamadas de a priori, porque elas são o } \\
\text { ponto de partida de um raciocínio } \\
\text { experimental (veja p.59 e as }\end{array}$ \\
\hline
\end{tabular}

${ }^{91}$ N.T. EULER, Leonhard- matemático suíço, nascido em 1707. Com mais de 900 publicações, teve influência decisiva no desenvolvimento da matemática. http://www.pdmi.ras.ru/EIMI/EulerBio.html http://www-history.mcs.st-and.ac.uk/Biographies/Euler.html

${ }^{92}$ N.T. Sabe-se, na sua maior parte, que as propriedades foram inicialmente observadas somente pela indução, e que seguidamente os geômetras trabalharam para fundamentá-las com sólidas demonstrações. Foi nisso que Fermat, entre todos, se empenhou com o mais alto zelo, e com uma felicidade e um sucesso satisfatórios. (Tradução nossa)

${ }^{93}$ Euler, Acta academia scientiarum imperialis Petropolitana, anno MDCCLXXX, pars posterior, p.. $38, \S 1$. 


\begin{abstract}
et suivantes), mais au point de vue de l'idéogénèse, ce sont en réalité des idées $a$ posteriori. En un mot, l'induction a dû être la forme de raisonnement primitive et générale, et les idées que les philosophes et les savants prennent constamment pour des idées a priori, ne sont au fond que des idées a posteriori.
\end{abstract}

Le mathématicien et le naturaliste ne diffèrent pas quand ils vont à la recherche des principes. Les uns et les autres induisent, font des hypothèses et expérimentent, c'est-à-dire font des tentatives pour vérifier l'exactitude de leurs idées. Mais quand le mathématicien et le naturaliste sont arrivés à leurs principes, ils diffèrent complètement alors. En effet, ainsi que je l'ai déjà dit ailleurs, le principe du mathématicien devient absolu, parce qu'il ne s'applique point à la réalité objective telle qu'elle est, mais à des relations de choses considérées dans des conditions extrêmement simples et que le mathématicien choisit et crée en quelque sorte dans son esprit. Or, ayant ainsi la certitude qu'il n'y a pas à faire intervenir dans le raisonnement d'autres conditions que celles qu'il a déterminées, le principe reste absolu, conscient, adéquat à l'esprit, et la déduction logique est également absolue et certaine ; il n'a plus subsequentes) ${ }^{94}$, mas, sob o ponto de vista da origem da palavra (idéogénèse, em francês ${ }^{95}$, são na verdade ideias a posteriori. Em uma palavra, a indução teve que ser a forma de raciocínio primitivo e geral e as ideias que os filósofos e os estudiosos tomam constantemente por ideias a priori não são, no fundo, senão ideias a posteriori.

O matemático e o naturalista não são diferentes quando vão à procura dos princípios. Uns e outros induzem, fazem hipóteses e experimentam, isto é, fazem tentativas para verificar a exatidão de suas ideias. Mas, quando o matemático e o naturalista chegam a seus princípios, então eles diferem totalmente. De fato, como eu já disse alhures, o princípio do matemático se torna absoluto porque ele não se aplica de forma alguma à realidade objetiva tal como ela é, mas a relações de coisas consideradas em condições extremamente simples e que o matemático escolhe e cria de algum modo em seu espírito. Logo, tendo assim a certeza de que não há nada a fazer ali para intervir no raciocínio de outras condições que não aquelas que ele determinou, o princípio permanece absoluto, consciente, adequado ao espírito, e a dedução lógica é igualmente absoluta e certa; ele não precisa mais de verificação experimental, a lógica basta.

\footnotetext{
94 N.T. No texto original, essa página se refere ao início do capítulo II: Da ideia a priori e da dúvida no raciocínio experimental, que não foi tratado no presente trabalho.

${ }^{95}$ N.T. Idéogénèse: um conceito de linguística que diz que ela é a produtora da ideia singular que constituiu a matéria da palavra. (BOONE, A. et JOLY, A, 1966).

Disponível em: http://nlip.pcu.ac.kr/guillaume/oldguillaume/dico/ideogenese.htm

Ainda de acordo com Gustave Guillaume, a construção da palavra se compõe de duas fases: primeiro a idéogénèse , que é uma operação de discernimento geradora de uma matéria nocional particular ; segundo a morfogênese, que é uma operação de compreensão, constituída de uma série de operações formalizadoras da matéria nocional e constituinte da categoria gramatical, isto é, da parte de linguagem ou parte do discurso, segundo a terminologia corrente (apud Jean Philippe BABU- Disponível em:

http://www2.ac-toulouse.fr/ien32auch1/Condom/conferences/influence grammaire greco latine Philippe Babu..pdf, Tradução nossa)
} 
besoin de vérification expérimentale, la logique suffit.

La situation du naturaliste est bien différente ; la proposition générale à laquelle il est arrivé, ou le principe sur lequel il s'appuie, reste relatif et provisoire parce qu'il représente des relations complexes qu'il n'a jamais la certitude de pouvoir connaître toutes. Dès lors, son principe est incertain, puisqu'il est inconscient et non adéquat à l'esprit ; dès lors les déductions, quoique très logiques, restent toujours douteuses, et il faut nécessairement alors invoquer l'expérience pour contrôler la conclusion de ce raisonnement déductif. Cette différence entre les mathématiciens et les naturalistes est capitale au point de vue de la certitude de leurs principes et des conclusions à en tirer; mais le mécanisme du raisonnement déductif est exactement le même pour les deux. Tous deux partent d'une proposition ; seulement le mathématicien dit : Ce point de départ étant donné, tel cas particulier en résulte nécessairement. Le naturaliste dit : Si ce point de départ était juste, tel cas particulier en résulterait comme conséquence.

Quand ils partent d'un principe, le mathématicien et le naturaliste emploient donc l'un et l'autre la déduction. Tous deux raisonnent en faisant un syllogisme ; seulement, pour le naturaliste, c'est un syllogisme dont la conclusion reste dubitative et demande vérification, parce que son principe est inconscient. C'est là le raisonnement expérimental ou dubitatif, le seul qu'on puisse employer quand on raisonne sur les phénomènes naturels; si I'on voulait supprimer le doute et si l'on se passait de l'expérience, on n'aurait plus aucun critérium pour savoir si l'on est dans le faux ou dans le vrai, parce que, je le
A situação do naturalista é bem diferente; a proposição geral à qual ele chegou, ou o princípio no qual ele se apoia, permanece relativa e provisória porque representa relações complexas que ele nunca tem a certeza de poder conhecer em sua totalidade. Assim, seu princípio é incerto, uma vez que ele é inconsciente e não adequado ao espírito; assim, as deduções, embora muito lógicas, continuam sempre duvidosas e por isso é preciso necessariamente invocar a experiência para controlar a conclusão desse raciocínio dedutivo. Essa diferença entre os matemáticos e os naturalistas é capital do ponto de vista da certeza de seus princípios e das conclusões a tirar deles; mas o mecanismo do raciocínio dedutivo é exatamente o mesmo para os dois. Ambos partem de uma proposição; só que o matemático diz: dado este ponto de partida, tal caso particular resulta obrigatoriamente dele. O naturalista diz: Se este ponto de partida fosse correto, tal caso particular resultaria como consequência dele.

Portanto, quando eles partem de um princípio, tanto o matemático quanto o naturalista empregam a dedução. Ambos raciocinam fazendo um silogismo; só que, para o naturalista, é um silogismo cuja conclusão permanece dubitativa e requer verificação porque seu princípio é inconsciente. Aí está o raciocínio experimental ou dubitativo, o único que se pode empregar quando se raciocina a respeito dos fenômenos naturais; se se quisesse suprimir a dúvida e se se abrisse mão da experiência, não se teria mais nenhum critério para saber se se está no falso ou no verdadeiro, porque, repito, o 
répète, le principe est inconscient et qu'il faut en appeler alors à nos sens.

De tout cela je conclurai que l'induction et la déduction appartiennent à toutes les sciences. Je ne crois pas que l'induction et la déduction constituent réellement deux formes de raisonnement essentiellement distinctes. L'esprit de l'homme a, par nature, le sentiment ou l'idée d'un principe qui régit les cas particuliers. II procède toujours instinctivement d'un principe qu'il a acquis ou qu'il invente par hypothèse; mais il ne peut jamais marcher dans les raisonnements autrement que par syllogisme, c'est-à-dire en procédant du général au particulier.

En physiologie, un organe déterminé fonctionne toujours par un seul et même mécanisme ; seulement, quand le phénomène se passe dans d'autres conditions ou dans un milieu différent, la fonction prend des aspects divers; mais, au fond, sa nature reste la même. Je pense qu'il n'y a pour l'esprit qu'une seule manière de raisonner, comme il n'y a pour le corps qu'une seule manière de marcher. Seulement, quand un homme s'avance, sur un terrain solide et plan, dans un chemin direct qu'il connaît et voit dans toute son étendue, il marche vers son but d'un pas sûr et rapide. Quand au contraire un homme suit un chemin tortueux dans l'obscurité et sur un terrain accidenté et inconnu, il craint les précipices, et n'avance qu'avec précaution et pas à pas. Avant de procéder à un second pas, il doit s'assurer que le pied placé le premier repose sur un point résistant puis s'avancer ainsi en vérifiant à chaque instant par l'expérience la solidité du sol, et en modifiant toujours la direction de sa marche suivant ce qu'il rencontre. Tel est l'expérimentateur qui ne doit jamais dans princípio é inconsciente e é preciso, então, apelar para os nossos sentidos.

De tudo isto concluirei que a indução e a dedução pertencem a todas as ciências. Eu não acho que a indução e a dedução constituam realmente duas formas de raciocínio essencialmente distintas. 0 espírito do homem tem, por natureza, o sentimento ou a ideia de um princípio que rege os casos particulares. Ele procede sempre instintivamente a partir de um princípio que ele adquiriu ou que ele inventa por hipótese; mas ele não tem como caminhar no raciocínio senão pelo silogismo, isto é, procedendo do geral ao particular.

Em fisiologia, um determinado órgão funciona sempre por um único e mesmo mecanismo; somente quando o fenômeno se passa em outras condições ou em um meio diferente é que a função adquire aspectos diversos; mas, no fundo, sua natureza continua a mesma. Eu penso que há para o espírito apenas uma única maneira de raciocinar, assim como há para o corpo apenas uma maneira de caminhar. Só que, quando um homem avança sobre um terreno sólido e plano, num caminho direto que ele conhece e que ele vê em toda a sua extensão, ele caminha em direção ao seu objetivo com um passo seguro e rápido. Quando, pelo contrário, um homem segue por um caminho tortuoso, no escuro, e num terreno acidentado e desconhecido, ele teme os precipícios e só avança com precaução e passo a passo. Antes de dar um segundo passo, ele deve se assegurar de que o pé colocado primeiramente repousa sobre um ponto firme, para depois avançar assim, verificando a cada instante pela experiência a solidez do terreno e modificando sempre a direção da sua marcha de acordo com o que 
ses recherches aller au-delà du fait, sans quoi il courrait le risque de s'égarer. Dans les deux exemples précédents l'homme s'avance sur des terrains différents et dans des conditions variables, mais n'en marche pas moins par le même procédé physiologique. De même, quand l'expérimentateur déduira des rapports simples de phénomènes précis et d'après des principes connus et établis, le raisonnement se développera d'une façon certaine et nécessaire, tandis que, quand il se trouvera au milieu de rapports complexes, ne pouvant s'appuyer que sur des principes incertains et provisoires, le même expérimentateur devra alors avancer avec précaution et soumettre à l'expérience chacune des idées qu'il met successivement en avant. Mais, dans ces deux cas, l'esprit raisonnera toujours de même et par le même procédé physiologique, seulement il partira d'un principe plus ou moins certain.

Quand un phénomène quelconque nous frappe dans la nature, nous nous faisons une idée sur la cause qui le détermine. L'homme, dans sa première ignorance, supposa des divinités attachées à chaque phénomène. Aujourd'hui le savant admet des forces ou des lois; c'est toujours quelque chose qui gouverne le phénomène. L'idée, qui nous vient à la vue d'un phénomène, est dite $a$ priori. Or, il nous sera facile de montrer plus tard que cette idée a priori, qui surgit en nous à propos d'un fait particulier, renferme toujours implicitement, et en quelque sorte à notre insu, un principe auquel nous voulons ramener le fait particulier. De sorte que, quand nous croyons aller d'un cas particulier à un principe, c'est-à-dire induire, nous déduisons réellement ; seulement, l'expérimentateur se dirige d'après un ele encontra. Assim é o experimentador, que não deve jamais, em suas pesquisas, ir além do fato, sem o que ele correria o risco de se perder. Nos dois exemplos precedentes, o homem avança sobre terrenos diferentes e em condições variáveis, mas não deixa de caminhar pelo mesmo procedimento fisiológico. Da mesma forma, quando o experimentador deduzir relações simples de fenômenos precisos e segundo princípios conhecidos e estabelecidos, o raciocínio se desenvolverá de uma forma precisa e necessária, enquanto que, quando ele se encontrar em meio a relações complexas, não podendo se apoiar senão em princípios incertos e provisórios, o mesmo experimentador deverá então avançar com precaução e submeter à experiência cada uma das ideias que ele coloca sucessivamente adiante. Mas, nesses dois casos, o espírito raciocinará sempre da mesma forma e pelo mesmo procedimento fisiológico, só que ele partirá de um princípio mais ou menos certo.

Quando um fenômeno qualquer nos atinge na natureza, fazemos uma ideia sobre a causa que o determina. O homem, em sua ignorância primitiva, supôs divindades ligadas a cada fenômeno. Hoje, o estudioso admite forças ou leis; é sempre alguma coisa que governa o fenômeno. A ideia que nos surge, à vista de um fenômeno, é dita $a$ priori. Logo, será fácil mostrar mais tarde que esta ideia a priori, que surgiu em nós a propósito de um fato particular, encerra sempre, implicitamente e de alguma forma sem o nosso conhecimento, um princípio ao qual nós queremos reportar o fato particular. De forma que, quando acreditamos ir de um caso particular a um princípio, isto é, induzir, nós na verdade deduzimos; só que o experimentador se guia segundo um princípio suposto ou provisório 
principe supposé ou provisoire qu'il modifie à chaque instant, parce qu'il cherche dans une obscurité plus ou moins complète. À mesure que nous rassemblons les faits, nos principes deviennent de plus en plus généraux et plus assurés ; alors nous acquérons la certitude que nous déduisons. Mais néanmoins, dans les sciences expérimentales, notre principe doit toujours rester provisoire, parce que nous n'avons jamais la certitude qu'il ne renferme que les faits et les conditions que nous connaissons. En un mot, nous déduisons toujours par hypothèse, jusqu'à vérification expérimentale. Un expérimentateur ne peut donc jamais se trouver dans le cas des mathématiciens, précisément parce que le raisonnement expérimental reste de sa nature toujours dubitatif. Maintenant, on pourra, si l'on veut, appeler le raisonnement dubitatif de l'expérimentateur l'induction, et le raisonnement affirmatif du mathématicien, la déduction; mais ce sera là une distinction qui portera sur la certitude ou l'incertitude du point de départ du raisonnement, mais non sur la manière dont on raisonne. que ele modifica a cada instante, porque ele pesquisa em uma obscuridade mais ou menos completa. À medida que reunimos os fatos, nossos princípios se tornam cada vez mais gerais e mais seguros; então nós adquirimos a certeza de que deduzimos. No entanto, nas ciências experimentais, nosso princípio deve sempre permanecer provisório, porque nunca temos a certeza de que ele encerra apenas os fatos e as condições que nós conhecemos. Em uma palavra, nós deduzimos sempre por hipótese, até a verificação experimental. Um experimentador nunca pode, portanto, se encontrar na situação dos matemáticos, justamente porque o raciocínio experimental permanece com a sua natureza sempre dubitativa. Agora, se se quiser, poderá se chamar de indução o raciocínio dubitativo do experimentador e de dedução o raciocínio afirmativo do matemático; mas esta será uma distinção feita sobre a certeza ou incerteza do ponto de partida do raciocínio, e não sobre a maneira segundo a qual raciocinamos.

\section{VI}

Da dúvida no raciocínio experimental

\section{Expérimental}

Du doute dans le raisonnement

Je résumerai le paragraphe précédent en disant qu'il me semble n'y avoir qu'une seule forme de raisonnement : la déduction par syllogisme. Notre esprit, quand il le voudrait, ne pourrait pas raisonner autrement, et, si c'était ici le lieu, je pourrais essayer d'appuyer ce que j'avance par des arguments physiologiques. Mais pour trouver la vérité scientifique, il importe peu au fond de savoir comment notre esprit
Eu resumirei o parágrafo precedente dizendo que não me parece haver aqui senão uma forma de raciocínio: a dedução por silogismo. Nosso espírito, mesmo que quisesse, não poderia raciocinar de outra forma e, se aqui fosse o lugar, eu poderia tentar dar suporte ao que digo com argumentos fisiológicos. Mas, para encontrar a verdade científica, pouco importa, no fundo, saber como nosso 
raisonne ; il suffit de le laisser raisonner naturellement, et dans ce cas il partira toujours d'un principe pour arriver à une conclusion. La seule chose que nous ayons à faire ici, c'est d'insister sur un précepte qui prémunira toujours l'esprit contre les causes innombrables d'erreur qu'on peut rencontrer dans l'application de la méthode expérimentale.

Ce précepte général, qui est une des bases de la méthode expérimentale, c'est le doute ; et il s'exprime en disant que la conclusion de notre raisonnement doit toujours rester dubitative quand le point de départ ou le principe n'est pas une vérité absolue. Or nous avons vu qu'il n'y a de vérité absolue que pour les principes mathématiques ; pour tous les phénomènes naturels, les principes desquels nous partons, de même que les conclusions auxquelles nous arrivons, ne représentent que des vérités relatives. L'écueil de l'expérimentateur consistera donc à croire connaître ce qu'il ne connaît pas, et à prendre pour des vérités absolues des vérités qui ne sont que relatives. De sorte que la règle unique et fondamentale de l'investigation scientifique se réduit au doute, ainsi que l'ont déjà proclamé d'ailleurs de grands philosophes.

Le raisonnement expérimental est précisément l'inverse du raisonnement scolastique. La scolastique veut toujours un point de départ fixe et indubitable, et ne pouvant le trouver ni dans les choses extérieures, ni dans la raison, elle l'emprunte à une source irrationnelle quelconque : telle qu'une révélation, une tradition ou une autorité conventionnelle ou arbitraire. Une fois le point de départ posé, le scolastique ou le systématique en déduit logiquement toutes les conséquences, en invoquant même l'observation ou espírito raciocina; basta deixá-lo raciocinar naturalmente e, assim, ele partirá sempre de um princípio para chegar a uma conclusão. $A$ única coisa que temos a fazer aqui é insistir sobre um preceito que protegerá sempre o espírito contra as incontáveis causas de erros que se pode encontrar na aplicação do método experimental.

Este preceito geral, que é uma das bases do método experimental, é a dúvida; e ele se expressa dizendo que a conclusão de nosso raciocínio deve sempre permanecer dubitativa quando o ponto de partida ou o princípio não é uma verdade absoluta. Mas nós vimos que não há verdade absoluta a não ser para os princípios matemáticos; para todos os fenômenos naturais, os princípios dos quais partimos, assim como as conclusões às quais chegamos, não representam senão verdades relativas. A dificuldade do experimentador consistirá, portanto, em acreditar conhecer o que ele não conhece e em tomar por verdades absolutas verdades que são apenas relativas. De tal modo que a regra única e fundamental da investigação científica se reduz à dúvida, como aliás já proclamaram anteriormente grandes filósofos.

O raciocínio experimental é exatamente o inverso do raciocínio escolástico. A escolástica demanda sempre um ponto de partida fixo e indubitável e, não podendo encontrá-lo nem nas coisas exteriores, nem na razão, ela o empresta de uma fonte irracional qualquer: tal como uma revelação, uma tradição ou uma autoridade convencional ou arbitrária. Uma vez estabelecido o ponto de partida, a escolástica ou a sistemática dele deduz logicamente todas as consequências, invocando inclusive a observação ou a 
l'expérience des faits comme arguments quand ils sont en sa faveur; la seule condition est que le point de départ restera immuable et ne variera pas selon les expériences et les observations, mais qu'au contraire, les faits seront interprétés pour s'y adapter. L'expérimentateur au contraire n'admet jamais de point de départ immuable ; son principe est un postulat dont il déduit logiquement toutes les conséquences, mais sans jamais le considérer comme absolu et en dehors des atteintes de l'expérience. Les corps simples des chimistes ne sont des corps simples que jusqu'à preuve du contraire. Toutes les théories qui servent de point de départ au physicien, au chimiste, et à plus forte raison au physiologiste, ne sont vraies que jusqu'à ce qu'on découvre qu'il y a des faits qu'elles ne renferment pas ou qui les contredisent. Lorsque ces faits contradictoires se montreront bien solidement établis, loin de se roidir, comme le scolastique ou le systématique, contre l'expérience, pour sauvegarder son point de départ, l'expérimentateur s'empressera, au contraire, de modifier sa théorie, parce qu'il sait que c'est la seule manière d'avancer et de faire des progrès dans les sciences. L'expérimentateur doute donc toujours, même de son point de départ ; il a l'esprit nécessairement modeste et souple, et accepte la contradiction à la seule condition qu'elle lui soit prouvée. Le scolastique ou le systématique, ce qui est la même chose, ne doute jamais de son point de départ, auquel il veut tout ramener; il a l'esprit orgueilleux et intolérant et n'accepte pas la contradiction, puisqu'il n'admet pas que son point de départ puisse changer. Ce qui sépare encore le savant systématique du savant expérimentateur, c'est que le premier impose son idée, tandis que le second ne la donne jamais que pour ce experiência dos fatos como argumentos quando eles estão a seu favor; a única condição é que o ponto de partida permanecerá imutável e não variará de acordo com as experiências e as observações, mas que, ao contrário, os fatos serão interpretados para se adaptarem a ele. O experimentador, ao contrário, jamais admite um ponto de partida imutável; seu princípio é um postulado do qual ele deduz logicamente todas as consequências, mas sem jamais considerá-lo como absoluto e fora do alcance da experiência. Os corpos simples dos químicos não são senão corpos simples, até prova em contrário. Todas as teorias que servem de ponto de partida ao físico, ao químico e com mais forte razão ao fisiologista não são verdadeiras até que se descubra que há fatos que elas não encerram ou que as contradizem. Quando esses fatos contraditórios se mostrarem solidamente estabelecidos, longe de se fechar, como o escolástico ou o sistemático, contra a experiência para proteger seu ponto de partida, o experimentador se apressará em modificar sua teoria, porque ele sabe que é a única maneira de avançar e de fazer progressos nas ciências. $O$ experimentador, portanto, sempre duvida, até mesmo de seu ponto de partida; ele tem espírito certamente modesto e maleável e aceita a contradição com a única condição de que ela seja provada. O escolástico ou o sistemático, o que é a mesma coisa, nunca duvida de seu ponto de partida, ao qual ele quer tudo conduzir; ele tem o espírito orgulhoso e intolerante e não aceita a contradição, uma vez que não admite que seu ponto de partida possa mudar. 0 que separa ainda o estudioso sistemático do estudioso experimentador é que o primeiro impõe sua ideia, enquanto o segundo nunca dá a ela mais valor do que ela tem. Por fim, uma outra característica essencial que 
qu'elle vaut. Enfin, un autre caractère essentiel qui distingue le raisonnement expérimental du raisonnement scolastique, c'est la fécondité de l'un et la stérilité de l'autre. C'est précisément le scolastique qui croit avoir la certitude absolue qui n'arrive à rien : cela se conçoit puisque, par son principe absolu, il se place en dehors de la nature dans laquelle tout est relatif. C'est au contraire l'expérimentateur, qui doute toujours et qui ne croit posséder la certitude absolue sur rien, qui arrive à maîtriser les phénomènes qui l'entourent et à étendre sa puissance sur la nature. L'homme peut donc plus qu'il ne sait, et la vraie science expérimentale ne lui donne la puissance qu'en lui montrant qu'il ignore. Peu importe au savant d'avoir la vérité absolue, pourvu qu'il ait la certitude des relations des phénomènes entre eux. Notre esprit est, en effet, tellement borné, que nous ne pouvons connaître ni le commencement ni la fin des choses ; mais nous pouvons saisir le milieu, c'est-à-dire ce qui nous entoure immédiatement.

Le raisonnement systématique ou scolastique est naturel à l'esprit inexpérimenté et orgueilleux ; ce n'est que par l'étude expérimentale approfondie de la nature qu'on parvient à acquérir l'esprit douteur de l'expérimentateur. II faut longtemps pour cela; et, parmi ceux qui croient suivre la voie expérimentale en physiologie et en médecine, il y a, comme nous le verrons plus loin, encore beaucoup de scolastiques. Je suis quant à moi convaincu qu'il n'y a que l'étude seule de la nature qui puisse donner au savant le sentiment vrai de la science. La philosophie, distingue o raciocínio experimental do raciocínio escolástico é a fecundidade de um e a esterilidade do outro. É justamente o escolástico que acredita ter a certeza absoluta que não chega a nada: isto se concebe porque, pelo seu princípio absoluto, ele se coloca fora da natureza, na qual tudo é relativo. Ocorre o contrário com o experimentador, que duvida sempre e que não crê possuir certeza absoluta sobre nada, que consegue dominar os fenômenos que o cercam e estender seu poder sobre a natureza. $O$ homem sabe, portanto, mais do que ele imagina e a verdadeira ciência experimental não Ihe dá poder senão quando lhe mostra o que ele ignora. Pouco importa ao estudioso ter a verdade absoluta, contanto que ele tenha a certeza das relações dos fenômenos entre si. Nosso espírito é, na verdade, tão limitado que não podemos conhecer nem o início e nem o fim das coisas; mas nós podemos compreender o meio, isto é, aquilo que nos rodeia de imediato.

O raciocínio sistemático ou escolástico é natural ao espírito inexperiente e orgulhoso; não é senão pelo estudo experimental aprofundado da natureza que se consegue adquirir o espírito questionador ${ }^{96}$ do experimentador. É necessário muito tempo para isso; e entre aqueles que acreditam seguir a via experimental em fisiologia e em medicina, há ainda, como veremos mais adiante, muitos escolásticos. Eu particularmente estou convencido de que é apenas o estudo da natureza que pode dar ao estudioso o verdadeiro sentimento da ciência. A filosofia, que eu considero como

\footnotetext{
${ }^{96}$ N.T. Optamos pela tradução deste termo como questionador, pois duvidoso poderia dar uma ideia incorreta sobre o que ele quis dizer com douteur, isto é, aquele que duvida, que faz perguntas, que não acredita à primeira mão no que vê.
} 
que je considère comme une excellente gymnastique de l'esprit, a malgré elle des tendances systématiques et scolastiques, qui deviendraient nuisibles pour le savant proprement dit. D'ailleurs, aucune méthode ne peut remplacer cette étude de la nature qui fait le vrai savant ; sans cette étude, tout ce que les philosophes ont pu dire et tout ce que j'ai pu répéter après eux dans cette introduction, resterait inapplicable et stérile.

Je ne crois donc pas, ainsi que je l'ai dit plus haut, qu'il y ait grand profit pour le savant à discuter la définition de l'induction et de la déduction, non plus que la question de savoir si l'on procède par l'un ou l'autre de ces soidisant procédés de l'esprit. Cependant l'induction baconienne est devenue célèbre et on en a fait le fondement de toute la philosophie scientifique. Bacon est un grand génie et l'idée de sa grande restauration des sciences est une idée sublime ; on est séduit et entraîné malgré soi par la lecture du Novum Organum et de l'Augmentum scientiarum. On reste dans une sorte de fascination devant cet amalgame de lueurs scientifiques, revêtues des formes poétiques les plus élevées. Bacon a senti la stérilité de la scolastique; il a bien compris et pressenti toute l'importance de l'expérience pour l'avenir des sciences. Cependant Bacon n'était point un savant, et il n'a point compris le mécanisme de la méthode expérimentale. II suffirait de citer, pour le prouver, les essais malheureux qu'il en a faits. Bacon recommande de fuir les hypothèses et les théories; nous avons vu cependant que ce sont les auxiliaires de la um excelente exercício do espírito, tem, apesar disso, tendências sistemáticas e escolásticas que seriam nocivas para o estudioso propriamente dito. Aliás, nenhum método pode substituir o estudo da natureza que faz o verdadeiro estudioso; sem esse estudo, tudo o que os filósofos disseram e tudo o que eu repeti depois deles nesta introdução seria inaplicável e estéril.

Eu não acredito, portanto, como já disse mais acima, que seja de grande proveito para o estudioso discutir a definição da indução e da dedução e nem a questão de saber se se procede por um ou outro desses supostos procedimentos do espírito. No entanto, a indução baconiana ficou famosa e tornou-se o fundamento de toda a filosofia científica. Bacon é um grande gênio e a ideia de sua grande restauração das ciências é uma ideia sublime; se é seduzido e treinado, não por vontade própria, pela leitura do Novum Organum e do Augmentum scientiarum. Fica-se numa espécie de fascinação diante desse amálgama de luzes científicas, revestidas das mais elevadas formas poéticas. Bacon percebeu a esterilidade da escolástica; ele realmente compreendeu e pressentiu toda a importância da experiência para o futuro das ciências. No entanto, Bacon não era de forma alguma um estudioso ${ }^{97}$ e ele não compreendeu o mecanismo do método experimental. Bastaria citar, para prová-lo, os ensaios infelizes que ele fez a esse respeito. Bacon recomenda evitar as hipóteses e teorias ${ }^{98}$; nós vimos, no entanto, que elas são as auxiliares do método,

\footnotetext{
${ }^{97}$ N.T. Claude Bernard se refere a estudioso no sentido de ele ser um pesquisador em ciências, como já alertamos em nota anterior e que fica bem claro neste caso.

${ }^{98}$ Bacon, CEuvres, édition par Fr. Riaux. Introduction, p. 30.
} 


\begin{tabular}{|c|c|}
\hline $\begin{array}{l}\text { méthode, indispensables comme les } \\
\text { échafaudages sont nécessaires pour } \\
\text { construire une maison. Bacon a eu, comme } \\
\text { toujours, des admirateurs outrés et des } \\
\text { détracteurs. Sans me mettre ni d'un côté ni } \\
\text { de l'autre, je dirai que, tout en } \\
\text { reconnaissant le génie de Bacon, je ne crois } \\
\text { pas plus que J. de Maistre, qu'il ait doté } \\
\text { l'intelligence humaine d'un nouvel } \\
\text { instrument, et il me semble, avec M. de } \\
\text { Rémusat, que l'induction ne diffère pas du } \\
\text { syllogisme. D'ailleurs je crois que les grands } \\
\text { expérimentateurs ont apparu avant les } \\
\text { préceptes de l'expérimentation, de même } \\
\text { que les grands orateurs ont précédé les } \\
\text { traités de rhétorique. Par conséquent, il ne } \\
\text { me paraît pas permis de dire, même en } \\
\text { parlant de Bacon, qu'il a inventé la méthode } \\
\text { expérimentale ; méthode que Galilée et } \\
\text { Torricelli ont si admirablement pratiquée, et } \\
\text { dont Bacon n'a jamais pu se servir. }\end{array}$ & $\begin{array}{l}\text { indispensáveis, como os andaimes são } \\
\text { necessários para se construir uma casa. } \\
\text { Bacon teve, como costuma acontecer, } \\
\text { admiradores exagerados e opositores. Sem } \\
\text { me colocar nem de um lado, nem de outro, } \\
\text { direi que, mesmo reconhecendo o gênio de } \\
\text { Bacon, eu não penso, como J. de Maistre, } \\
{ }^{100} \text { que ele tenha dotado a inteligência } \\
\text { humana de um novo instrumento e me } \\
\text { parece, como a M. de Rémusat, }{ }^{101} 102 \text { que a } \\
\text { indução não difere do silogismo. Aliás, eu } \\
\text { acho que os grandes experimentadores } \\
\text { apareceram antes dos preceitos da } \\
\text { experimentação, assim como os grandes } \\
\text { oradores precederam os tratados de } \\
\text { retórica. Consequentemente, não me } \\
\text { parece permitido dizer, mesmo em se } \\
\text { falando de Bacon, que ele inventou o } \\
\text { método experimental; método que Galileu e } \\
\text { Torricelli praticaram tão admiravelmente e } \\
\text { do qual Bacon jamais se serviu. }\end{array}$ \\
\hline $\begin{array}{l}\text { Quand Descartes part du doute universel et } \\
\text { répudie l'autorité, il donne des préceptes } \\
\text { bien plus pratiques pour l'expérimentateur } \\
\text { que ceux que donne Bacon pour l'induction. } \\
\text { Nous avons vu, en effet, que c'est le doute } \\
\text { seul qui provoque l'expérience ; c'est le } \\
\text { doute enfin qui détermine la forme du } \\
\text { raisonnement expérimental. }\end{array}$ & $\begin{array}{l}\text { Quando Descartes }{ }^{103} \text { parte da dúvida } \\
\text { universal e repudia a autoridade, ele fornece } \\
\text { preceitos bem mais práticos para o } \\
\text { experimentador do que aqueles fornecidos } \\
\text { por Bacon pela indução. Nós vimos, na } \\
\text { verdade, que é apenas a dúvida que produz } \\
\text { a experiência; é a dúvida, enfim, que } \\
\text { determina a forma do raciocínio } \\
\text { experimental. }\end{array}$ \\
\hline $\begin{array}{l}\text { Toutefois, quand il s } \\
\text { des sciences physio } \\
\text { bien déterminer sur }\end{array}$ & $\begin{array}{l}\text { Todavia, quando se trata da medicina e das } \\
\text { ciências fisiológicas, é importante } \\
\text { determinar seguramente sobre qual ponto }\end{array}$ \\
\hline
\end{tabular}

\footnotetext{
${ }_{99}^{9}$ N.T. De MAISTRE, Joseph- filósofo, escritor e diplomata francês, nascido em 1753. Escreveu um dos primeiros ensaios de interpretação histórica do fenômeno revolucionário em língua francesa e do ponto de vista da contrarrevolução. Disponível em: http://www.teses.usp.br/teses/disponiveis/8/8138/tde-10032010-114032/en.php

$100 \mathrm{~J}$. de Maistre, Examen de la philosophie de Bacon.

${ }^{101}$ N.T. De RÈmUSAT, Charles- político, filósofo e escritor francês, nascido em 1797. Biografia disponível em: http://persona.rin.ru/eng/view/f//36147/remusat-charles

102 De Rémusat, Bacon, sa vie, son temps et sa philosophie, 1857.

${ }^{103}$ Descartes, Discours sur la méthode.
} 


\begin{tabular}{|c|c|}
\hline $\begin{array}{l}\text { le doute, afin de le distinguer du scepticisme } \\
\text { et de montrer comment le doute } \\
\text { scientifique devient un élément de plus } \\
\text { grande certitude. Le sceptique est celui qui } \\
\text { ne croit pas à la science et qui croit à lui- } \\
\text { même; il croit assez en lui pour oser nier la } \\
\text { science et affirmer qu'elle n'est pas soumise } \\
\text { à des lois fixes et déterminées. Le douteur } \\
\text { est le vrai savant ; il ne doute que de lui- } \\
\text { même et de ses interprétations, mais il croit } \\
\text { à la science ; il admet même dans les } \\
\text { sciences expérimentales un critérium ou un } \\
\text { principe scientifique absolu. Ce principe est } \\
\text { le déterminisme des phénomènes, qui est } \\
\text { absolu aussi bien dans les phénomènes des } \\
\text { corps vivants que dans ceux des corps bruts } \\
\text { ainsi que nous le dirons plus tard (p. 108). }\end{array}$ & $\begin{array}{l}\text { deve recair a dúvida, a fim de distingui-la do } \\
\text { ceticismo e de mostrar como a dúvida } \\
\text { científica se torna um elemento de maior } \\
\text { certeza. O cético é aquele que não acredita } \\
\text { na ciência e que acredita em si mesmo; ele } \\
\text { crê em si o suficiente para ousar negar a } \\
\text { ciência e afirmar que ela não está submetida } \\
\text { a leis fixas e determinadas. Aquele que } \\
\text { dúvida é o verdadeiro estudioso; ele não } \\
\text { duvida senão dele mesmo e de suas } \\
\text { interpretações, mas ele crê na ciência; ele } \\
\text { admite até mesmo um critério ou um } \\
\text { princípio científico absoluto nas ciências } \\
\text { experimentais. Este princípio é } \\
\text { determinismo dos fenômenos que é } \\
\text { absoluto tanto nos fenômenos dos corpos } \\
\text { vivos como nos dos corpos brutos, como } \\
\text { veremos mais adiante. (p. 108) }{ }^{104}\end{array}$ \\
\hline $\begin{array}{l}\text { Enfin, comme conclusion de ce paragraphe } \\
\text { nous pouvons dire que, dans tout } \\
\text { raisonnement expérimental, il y a deux cas } \\
\text { possibles : ou bien l'hypothèse de } \\
\text { l'expérimentateur sera infirmée, ou bien elle } \\
\text { sera confirmée par l'expérience. Quand } \\
\text { l'expérience infirme l'idée préconçue, } \\
\text { l'expérimentateur doit rejeter ou modifier } \\
\text { son idée. Mais lors même que l'expérience } \\
\text { confirme pleinement l'idée préconçue, } \\
\text { l'expérimentateur doit encore douter; car } \\
\text { comme il s'agit d'une vérité inconsciente, sa } \\
\text { raison lui demande encore une contre- } \\
\text { épreuve. }\end{array}$ & $\begin{array}{l}\text { Finalmente, como conclusão deste } \\
\text { parágrafo, podemos dizer que em todo } \\
\text { raciocínio experimental há dois casos } \\
\text { possíveis: ou a hipótese do experimentador } \\
\text { será destruída ou ela será confirmada pela } \\
\text { experiência. Quando a experiência derruba a } \\
\text { ideia pré-concebida, o experimentador deve } \\
\text { rejeitar ou modificar sua ideia. Mas, mesmo } \\
\text { que a experiência confirme plenamente a } \\
\text { ideia pré-concebida, o experimentador deve } \\
\text { ainda duvidar; porque, como se trata de uma } \\
\text { verdade inconsciente, sua razão ainda lhe } \\
\text { pede uma contraprova. }\end{array}$ \\
\hline
\end{tabular}

\footnotetext{
104 N.T. Claude Bernard se refere ao item V, capítulo primeiro da segunda parte do livro, intitulado: Existe um determinismo absoluto nas condições de existência dos fenômenos naturais, assim como nos corpos vivos e nos corpos brutos. Esta parte do livro não foi tratada neste trabalho, que inclui a Introdução do livro e a primeira parte do livro.
} 


\begin{tabular}{|c|c|}
\hline $\begin{array}{l}\text { VII } \\
\text { Du principe du critérium } \\
\text { expérimental }\end{array}$ & $\begin{array}{l}\text { VII } \\
\text { Do princípio do critério experimental }\end{array}$ \\
\hline $\begin{array}{l}\text { Nous venons de dire qu'il faut douter, mais } \\
\text { ne point être sceptique. En effet, le } \\
\text { sceptique, qui ne croit à rien, n'a plus de } \\
\text { base pour établir son critérium, et par } \\
\text { conséquent il se trouve dans l'impossibilité } \\
\text { d'édifier la science; la stérilité de son triste } \\
\text { esprit résulte à la fois des défauts de son } \\
\text { sentiment et de l'imperfection de sa raison. } \\
\text { Après avoir posé en principe que } \\
\text { l'investigateur doit douter, nous avons } \\
\text { ajouté que le doute ne portera que sur la } \\
\text { justesse de son sentiment ou de ses idées en } \\
\text { tant qu'expérimentateur, ou sur la valeur de } \\
\text { ses moyens d'investigation, en tant } \\
\text { qu'observateur, mais jamais sur le } \\
\text { déterminisme, le principe même de la } \\
\text { science expérimentale. Revenons en } \\
\text { quelques mots sur ce point fondamental. }\end{array}$ & $\begin{array}{l}\text { Acabamos de dizer que é preciso duvidar, } \\
\text { mas sem ser cético de forma alguma. Na } \\
\text { verdade, o cético, que não acredita em nada, } \\
\text { não tem base para estabelecer seu critério e, } \\
\text { consequentemente, ele é incapaz de edificar } \\
\text { a ciência; a esterilidade de seu triste espírito } \\
\text { resulta, ao mesmo tempo, em defeitos de } \\
\text { seu sentimento e na imperfeição de seu } \\
\text { raciocínio. Após ter colocado em princípio } \\
\text { que o investigador deve duvidar, nós } \\
\text { acrescentamos que a dúvida não recairá } \\
\text { senão sobre a justeza de seu sentimento ou } \\
\text { de suas ideias como experimentador, ou } \\
\text { sobre o valor de seus meios de investigação } \\
\text { como observador, mas nunca sobre o } \\
\text { determinismo, o próprio princípio da ciência } \\
\text { experimental. Retomemos, em algumas } \\
\text { palavras, esse ponto fundamental. }\end{array}$ \\
\hline $\begin{array}{l}\text { L'expérimentateur doit douter de son } \\
\text { sentiment, c'est-à-dire de l'idée a priori ou } \\
\text { de la théorie qui lui servent de point de } \\
\text { départ ; c'est pourquoi il est de précepte } \\
\text { absolu de soumettre toujours son idée au } \\
\text { critérium expérimental pour en contrôler la } \\
\text { valeur. Mais quelle est au juste la base de ce } \\
\text { critérium expérimental ? Cette question } \\
\text { pourra paraître superflue après avoir dit et } \\
\text { répété avec tout le monde que ce sont les } \\
\text { faits qui jugent l'idée et nous donnent } \\
\text { l'expérience. Les faits seuls sont réels, dit- } \\
\text { on, et il faut s'en rapporter à eux d'une } \\
\text { manière entière et exclusive. C'est un fait, } \\
\text { un fait brutal, répète-t-on encore souvent; } \\
\text { il n'y a pas à raisonner, il faut s'y soumettre. } \\
\text { Sans doute, j'admets que les faits sont les } \\
\text { seules réalités qui puissent donner la } \\
\text { formule à l'idée expérimentale et lui servir }\end{array}$ & $\begin{array}{l}\text { O experimentador deve duvidar de seu } \\
\text { sentimento, isto é, da ideia a priori ou da } \\
\text { teoria que lhe serve de ponto de partida; por } \\
\text { esta razão, ele tem o preceito absoluto de } \\
\text { sempre submeter sua ideia ao critério } \\
\text { experimental para controlar o seu valor. Mas } \\
\text { qual é justamente a base desse critério } \\
\text { experimental? Esta questão poderá parecer } \\
\text { supérflua depois de se ter dito e repetido } \\
\text { com todo mundo que são os fatos que } \\
\text { avaliam a ideia e nos dão a experiência. Diz- } \\
\text { se que somente os fatos são reais e é } \\
\text { necessário reportar-se a eles de uma } \\
\text { maneira completa e exclusiva. É um fato, um } \\
\text { fato brutal, repete-se ainda } \\
\text { frequentemente; não há que se raciocinar, é } \\
\text { preciso submeter-se a ele. Sem dúvida, } \\
\text { admito que os fatos são as únicas realidades } \\
\text { que poderiam dar a fórmula a uma ideia }\end{array}$ \\
\hline
\end{tabular}


en même temps de contrôle ; mais c'est à la condition que la raison les accepte. Je pense que la croyance aveugle dans le fait qui prétend faire taire la raison est aussi dangereuse pour les sciences expérimentales que les croyances de sentiment ou de foi qui, elles aussi, imposent silence à la raison. En un mot, dans la méthode expérimentale comme partout, le seul critérium réel est la raison.

Un fait n'est rien par lui-même, il ne vaut que par l'idée qui s'y rattache ou par la preuve qu'il fournit. Nous avons dit ailleurs que, quand on qualifie un fait nouveau de découverte, ce n'est pas le fait lui-même qui constitue la découverte, mais bien l'idée nouvelle qui en dérive ; de même, quand un fait prouve, ce n'est point le fait lui-même qui donne la preuve, mais seulement le rapport rationnel qu'il établit entre le phénomène et sa cause. C'est ce rapport qui est la vérité scientifique et qu'il s'agit maintenant de préciser davantage.

Rappelons-nous comment nous avons caractérisé les vérités mathématiques et les vérités expérimentales. Les vérités mathématiques une fois acquises, avonsnous dit, sont des vérités conscientes et absolues, parce que les conditions idéales de leur existence sont également conscientes et connues par nous d'une manière absolue. Les vérités expérimentales, au contraire, sont inconscientes et relatives, parce que les conditions réelles de leur existence sont inconscientes et ne peuvent nous être connues que d'une manière relative à l'état actuel de notre science. Mais si les vérités expérimentales qui servent de base à nos raisonnements sont tellement enveloppées dans la réalité complexe des phénomènes experimental e lhe servir, ao mesmo tempo, de controle; mas com a condição de que a razão Ihes aceite. Eu acho que a crença cega no fato que pretende calar a razão é tão perigosa para as ciências experimentais quanto as crenças de sentimento ou de fé que também impõem silêncio à razão. Em uma palavra, no método experimental, assim como em tudo, o único critério real é a razão.

Um fato por si só não é nada, ele só vale pela ideia à qual está ligado ou pela prova que ele fornece. Nós dissemos alhures que, quando qualificamos um fato novo de descoberta, não é o fato em si mesmo que constitui a descoberta, mas a nova ideia que dele deriva; da mesma forma, quando um fato prova algo, não é de forma alguma o fato em si que fornece a prova, mas apenas a relação racional que ele estabelece entre o fenômeno e sua causa. É essa relação que é a verdade científica e que se deve agora especificar ainda mais.

Lembremo-nos de como caracterizamos as verdades matemáticas e as verdades experimentais. As verdades matemáticas, uma vez obtidas, como dissemos, são verdades conscientes e absolutas, porque as condições ideais de sua existência são igualmente conscientes e por nós conhecidas de uma maneira absoluta. As verdades experimentais, pelo contrário, são inconscientes e relativas, porque as condições reais de sua existência são inconscientes e só podem ser conhecidas de uma maneira relativa, no estado atual de nossa ciência. Mas se as verdades experimentais que servem de base a nossos raciocínios estão tão encarceradas na realidade complexa dos fenômenos naturais que elas só elas aparecem por fragmentos, 
naturels qu'elles ne nous apparaissent que par lambeaux, ces vérités expérimentales n'en reposent pas moins sur des principes qui sont absolus parce que, comme ceux des vérités mathématiques, ils s'adressent à notre conscience et à notre raison. En effet, le principe absolu des sciences expérimentales est un déterminisme nécessaire et conscient dans les conditions des phénomènes. De telle sorte qu'un phénomène naturel, quel qu'il soit, étant donné, jamais un expérimentateur ne pourra admettre qu'il y ait une variation dans l'expression de ce phénomène sans qu'en même temps il ne soit survenu des conditions nouvelles dans sa manifestation ; de plus, il a la certitude a priori que ces variations sont déterminées par des rapports rigoureux et mathématiques. L'expérience ne fait que nous montrer la forme des phénomènes; mais le rapport d'un phénomène à une cause déterminée est nécessaire et indépendant de l'expérience, et il est forcément mathématique et absolu. Nous arrivons ainsi à voir que le principe du critérium des sciences expérimentales est identique au fond à celui des sciences mathématiques, puisque de part et d'autre, ce principe est exprimé par un rapport des choses nécessaire et absolu. Seulement dans les sciences expérimentales ces rapports sont entourés par des phénomènes nombreux, complexes et variés à l'infini, qui les cachent à nos regards. À l'aide de l'expérience nous analysons, nous dissocions ces phénomènes, afin de les réduire à des relations et à des conditions de plus en plus simples. Nous voulons ainsi saisir la forme de la vérité scientifique, c'est-à-dire trouver la loi qui nous donnerait la clef de toutes les variations des phénomènes. Cette analyse expérimentale est le seul moyen que nous ayons pour aller à la recherche de la vérité essas verdades experimentais, nem por isso, repousam sobre os princípios que são absolutos porque, como aquelas das verdades matemáticas, elas se remetem à nossa consciência e à nossa razão. $\mathrm{Na}$ verdade, o princípio absoluto das ciências experimentais é um determinismo necessário e consciente nas condições dos fenômenos. De tal sorte que, uma vez estabelecido um fenômeno natural, seja ele qual for, um experimentador jamais poderá admitir que há uma variação na expressão desse fenômeno sem que, ao mesmo tempo, não apareçam novas condições na sua manifestação; além disso, ele tem a certeza, a priori, de que essas variações são determinadas por relações rigorosas e matemáticas. A experiência apenas nos mostra a forma dos fenômenos; mas a relação de um fenômeno a uma determinada causa é necessária e independente da experiência e é obrigatoriamente matemática e absoluta. Chegaremos assim a constatar que o princípio do critério das ciências experimentais é idêntico, no fundo, ao das ciências matemáticas, uma vez que em ambos ele é expresso por uma relação das coisas necessárias e absolutas. Só que nas ciências experimentais essas relações são cercadas de fenômenos que são numerosos, complexos e variados ao infinito, que os escondem de nosso olhar. Com a ajuda da experiência, analisamos, dissociamos esses fenômenos, para reduzi-los a relações e a condições cada vez mais simples. Queremos assim compreender a forma da verdade científica, isto é, encontrar a lei que nos daria a chave de todas as variações dos fenômenos. Essa análise experimental é o único meio que teríamos para chegar à pesquisa da verdade nas ciências naturais e o determinismo absoluto dos fenômenos dos quais nós temos consciência a priori é o 
dans les sciences naturelles, et le déterminisme absolu des phénomènes dont nous avons conscience a priori est le seul critérium ou le seul principe qui nous dirige et nous soutienne. Malgré nos efforts, nous sommes encore bien loin de cette vérité absolue ; et il est probable, surtout dans les sciences biologiques, qu'il ne nous sera jamais donné de la voir dans sa nudité. Mais cela n'a pas de quoi nous décourager, car nous en approchons toujours; et d'ailleurs nous saisissons, à l'aide de nos expériences, des relations de phénomènes qui, bien que partielles et relatives, nous permettent d'étendre de plus en plus notre puissance sur la nature.

De ce qui précède, il résulte que, si un phénomène se présentait dans une expérience avec une apparence tellement contradictoire, qu'il ne se rattachât pas d'une manière nécessaire à des conditions d'existence déterminées, la raison devrait repousser le fait comme un fait non scientifique. II faudrait attendre ou chercher par des expériences directes quelle est la cause d'erreur qui a pu se glisser dans l'observation. Il faut, en effet, qu'il y ait eu erreur ou insuffisance dans l'observation ; car l'admission d'un fait sans cause, c'est-àdire indéterminable dans ses conditions d'existence, n'est ni plus ni moins que la négation de la science. De sorte qu'en présence d'un tel fait un savant ne doit jamais hésiter ; il doit croire à la science et douter de ses moyens d'investigation. II perfectionnera donc ses moyens d'observation et cherchera par ses efforts à sortir de l'obscurité ; mais jamais il ne pourra lui venir à l'idée de nier le déterminisme absolu des phénomènes, parce que c'est précisément le sentiment de ce déterminisme qui caractérise le vrai savant. único critério ou o único princípio que nos dirige e nos sustenta. Apesar de nossos esforços, ainda estamos bem longe dessa verdade absoluta; e é provável, sobretudo nas ciências biológicas, que jamais nos será permitido desnudá-lo completamente. Mas isso não deve nos desencorajar, pois nos aproximamos sempre dele; e, além disso, nós aprendemos, com auxílio de nossas experiências, relações de fenômenos que, embora parciais e relativas, nos permitem ampliar cada vez mais nosso poder sobre a natureza.

Do que foi dito resulta que, se um fenômeno se apresentasse em uma experiência com uma aparência tão contraditória que não se ligasse de uma maneira adequada às condições de existência determinadas, a razão deveria rejeitar o fato como um fato não científico. Seria preciso esperar ou buscar por meio de experiências diretas a causa do erro que conseguiu escapar da observação. É preciso, na verdade, que tenha havido um erro ou uma insuficiência na observação; pois a admissão de um fato sem causa, isto é, indeterminável nas suas condições de existência, não é nada mais, nada menos, que a negação da ciência. De sorte que, na presença de um fato desse tipo, um estudioso não deve jamais hesitar; ele deve crer na ciência e duvidar de seus meios de investigação. Ele aperfeiçoará, portanto, seus meios de observação e procurará com seus esforços sair da obscuridade; mas jamais poderá vir à sua mente negar o determinismo absoluto dos fenômenos, porque é precisamente o sentimento desse determinismo que caracteriza o verdadeiro estudioso. 
II se présente souvent en médecine des faits mal observés et indéterminés qui constituent de véritables obstacles à la science, en ce qu'on les oppose toujours en disant : C'est un fait, il faut l'admettre. La science rationnelle fondée, ainsi que nous l'avons dit, sur un déterminisme nécessaire, ne doit jamais répudier un fait exact et bien observé ; mais par le même principe, elle ne saurait s'embarrasser de ces faits recueillis sans précision, n'offrant aucune signification, et qu'on fait servir d'arme à double tranchant pour appuyer ou infirmer les opinions les plus diverses. En un mot, la science repousse l'indéterminé ; et quand, en médecine, on vient fonder ses opinions sur le tact médical, sur l'inspiration ou sur une intuition plus ou moins vague des choses, on est en dehors de la science et on donne l'exemple de cette médecine de fantaisie qui peut offrir les plus grands périls en livrant la santé et la vie des malades aux lubies d'un ignorant inspiré. La vraie science apprend à douter et à s'abstenir dans l'ignorance.
Acontecem frequentemente em medicina fatos mal observados e indeterminados que constituem verdadeiros obstáculos à ciência, aos quais as pessoas se opõem sempre dizendo: é um fato, é preciso admiti-lo. A ciência racional baseada, assim como dissemos, em um determinismo necessário, não deve jamais repudiar um fato exato e bem observado; mas, pelo mesmo princípio, ela não poderia ser perturbada por esses fatos recolhidos sem precisão, que não oferecem qualquer significado e que são utilizados como uma faca de dois gumes para apoiar ou derrubar as opiniões mais diversas. Em uma palavra, a ciência rejeita o indeterminado; e quando, em medicina, fundamentamos as opiniões sobre o tato médico, sobre a inspiração ou sobre uma intuição mais ou menos vaga das coisas, estamos fora da ciência e damos o exemplo dessa medicina de fantasia que pode mostrar os maiores perigos, entregando a saúde e a vida dos enfermos aos caprichos de um ignorante inspirado. A verdadeira ciência aprende a duvidar e a se abster diante da ignorância.
VII

Da prova e da contraprova

Dissemos anteriormente que um experimentador que vê sua ideia confirmada por uma experiência deve, ainda assim, duvidar e solicitar uma contraprova.

Na verdade, para concluir com certeza que uma dada condição é a causa próxima de um fenômeno, não basta ter provado que essa condição sempre precede ou acompanha o fenômeno; é preciso ainda estabelecer que, uma vez suprimida essa condição, o fenômeno não mais se apresentará. Se se 


\begin{tabular}{|c|c|}
\hline $\begin{array}{l}\text { ne se montrera plus. Si l'on se bornait à la } \\
\text { seule preuve de présence, on pourrait à } \\
\text { chaque instant tomber dans l'erreur et } \\
\text { croire à des relations de cause à effet quand } \\
\text { il n'y a que simple coïncidence. Les } \\
\text { coïncidences constituent, ainsi que nous le } \\
\text { verrons plus loin, un des écueils les plus } \\
\text { graves que rencontre la méthode } \\
\text { expérimentale dans les sciences complexes } \\
\text { comme la biologie. C'est le post hoc, ergo } \\
\text { propter hoc des médecins auquel on peut se } \\
\text { laisser très facilement entraîner, surtout sile } \\
\text { résultat de l'expérience ou de l'observation } \\
\text { favorise une idée préconçue. }\end{array}$ & $\begin{array}{l}\text { limita somente à prova de presença, a todo } \\
\text { o momento pode-se cair no erro e acreditar } \\
\text { em relações de causa e efeito, quando o que } \\
\text { existe é apenas coincidência. As } \\
\text { coincidências constituem, como veremos } \\
\text { mais adiante, um dos obstáculos mais graves } \\
\text { com os quais se depara o método } \\
\text { experimental nas ciências complexas como a } \\
\text { biologia. É o post hoc, ergo propter hoc }{ }^{105} \\
\text { dos médicos ao qual podemos ser facilmente } \\
\text { conduzidos, sobretudo se o resultado da } \\
\text { experiência ou da observação favorece uma } \\
\text { ideia pré-concebida. }\end{array}$ \\
\hline $\begin{array}{l}\text { La contre-épreuve devient doncle caractère } \\
\text { essentiel et nécessaire de la conclusion du } \\
\text { raisonnement expérimental. Elle est } \\
\text { l'expression du doute philosophique porté } \\
\text { aussi loin que possible. C'est la contre- } \\
\text { épreuve qui juge si la relation de cause à } \\
\text { effet qui l'on cherche dans les phénomènes } \\
\text { est trouvée. Pour cela, elle supprime la } \\
\text { cause admise pour voir si l'effet persiste, } \\
\text { s'appuyant sur cet adage ancien et } \\
\text { absolument vrai : Sublata causa, tollitur } \\
\text { effectus. C'est ce qu'on appelle encore } \\
\text { l'experimentum crucis. }\end{array}$ & $\begin{array}{l}\text { A contraprova torna-se, portanto, o caráter } \\
\text { essencial e necessário da conclusão do } \\
\text { raciocínio experimental. Ela é a expressão da } \\
\text { dúvida filosófica levada tão longe quanto } \\
\text { possível. É a contraprova que julga se a } \\
\text { relação de causa e efeito que se procura nos } \\
\text { fenômenos é encontrada. Por isso ela } \\
\text { suprime a causa admitida para verificar se o } \\
\text { efeito persiste, apoiando-se sobre esse } \\
\text { adágio antigo e absolutamente verdadeiro: } \\
\text { Sublata causa, tollitur effectus. }{ }^{106} \text { Isso é o } \\
\text { que se chama também o experimentum } \\
\text { crucis. }{ }^{107}\end{array}$ \\
\hline $\begin{array}{l}\text { II ne faut pas confondre la contre-expérience } \\
\text { ou contre-épreuve avec ce qu'on a appelé } \\
\text { l'expérience comparative. Celle-ci, ainsi que } \\
\text { nous le verrons plus tard, n'est qu'une }\end{array}$ & $\begin{array}{l}\text { Não podemos confundir a contra- } \\
\text { experiência ou contraprova com aquilo que } \\
\text { foi chamado de experiência comparativa. } \\
\text { Esta, como veremos mais adiante, não é }\end{array}$ \\
\hline
\end{tabular}

105 Depois disto, portanto causado por isto. Expressão latina que expressa uma falácia lógica na qual se atribui uma relação causal entre dois eventos com base na sucessão temporal. Em outras palavras, essa falácia reflete a ideia de que se dois efeitos ocorrem em uma sequência cronológica, eles devem estar ligados entre si por uma relação de causa e efeito. http://plato.stanford.edu/entries/fallacies/

${ }^{106}$ Eliminada a causa, desaparece o efeito. http://www.dicionariodelatim.com.br/sublata-causa-tollitur-effectus/

107 Experimento crucial- Por volta do século XVII surgiram as primeiras reflexões sobre a natureza das experimentações. Alguns filósofos acreditavam que o conhecimento científico não era muito mais do que a boa aplicação de técnicas de observação e experimentação sobre os fenômenos naturais. Francis Bacon foi tão longe com essa alegação, a ponto de afirmar que era possível realizar o que ele chamou de experimento crucial, capaz de resolver qual das hipóteses em questão para um dado problema seria a mais correta, resolvendo definitivamente o problema. Essa ideia foi compartilhada até mesmo por grandes cientistas da época, como Newton. http://plato.stanford.edu/entries/physics-experiment/ 
observation comparative invoquée dans les circonstances complexes afin de simplifier les phénomènes et de se prémunir contre les causes d'erreur imprévues; la contreépreuve, au contraire, est un contrejugement s'adressant directement à la conclusion expérimentale et formant un de ses termes nécessaires. En effet, jamais en science la preuve ne constitue une certitude sans la contre-épreuve. L'analyse ne peut se prouver d'une manière absolue que par la synthèse qui la démontre en fournissant la contreépreuve ou la contreexpérience ; de même une synthèse qu'on effectuerait d'abord, devrait être démontrée ensuite par l'analyse. Le sentiment de cette contre-épreuve expérimentale nécessaire constitue le sentiment scientifique par excellence. II est familier aux physiciens et aux chimistes ; mais il est loin d'être aussi bien compris par les médecins. Le plus souvent, quand en physiologie et en médecine on voit deux phénomènes marcher ensemble et se succéder dans un ordre constant, on se croit autorisé à conclure que le premier est la cause du second. Ce serait là un jugement faux dans un très grand nombre de cas; les tableaux statistiques de présence ou d'absence ne constituent jamais des démonstrations expérimentales. Dans les sciences complexes comme la médecine, il faut faire en même temps usage de l'expérience comparative et de la contreépreuve. Il y a des médecins qui craignent et fuient la contre-épreuve; dès qu'ils ont des observations qui marchent dans le sens de leurs idées, ils ne veulent pas chercher des faits contradictoires dans la crainte de voir leurs hypothèses s'évanouir. Nous avons déjà dit que c'est là un très mauvais esprit : quand on veut trouver la vérité, on ne peut asseoir solidement ses idées qu'en cherchant à détruire ses propres senão uma observação comparativa invocada em circunstâncias complexas para simplificar os fenômenos e para se prevenir contra as causas de erros não previstos; a contraprova, pelo contrário, é um contrajulgamento endereçado diretamente à conclusão experimental e formando um de seus termos necessários. Na verdade, na ciência a prova jamais constitui uma certeza sem a contraprova. A análise não pode ser provada de maneira absoluta senão pela síntese que a demonstra, fornecendo a contraprova ou a contraexperiência; da mesma forma, uma síntese que se efetuaria inicialmente, deveria ser demonstrada em seguida pela análise. O sentimento desta contraprova experimental necessária constitui o sentimento científico por excelência. Ele é familiar aos físicos e aos químicos; mas ele está longe de ser tão bem compreendido pelos médicos. Frequentemente, quando em fisiologia e em medicina dois fenômenos são vistos caminhando juntos e se sucedendo numa ordem constante, é normal se crer autorizado a concluir que o primeiro é a causa do segundo. Esse seria um falso julgamento em um número muito grande de casos; as tabelas estatísticas de presença ou ausência nunca constituem demonstrações experimentais. Nas ciências complexas como a medicina, é preciso fazer uso ao mesmo tempo da experiência comparativa e da contraprova. Existem médicos que temem e fogem da contraprova; a partir do momento em que eles obtêm observações que caminham no sentido de suas ideias, eles não querem buscar fatos contraditórios, temendo ver suas hipóteses se desvanecerem. Já dissemos que esse é um espírito muito ruim: quando se quer encontrar a verdade, só se pode assentar solidamente as ideias buscando-se destruir suas próprias conclusões por 
conclusions par des contreexpériences. Or, la seule preuve qu'un phénomène joue le rôle de cause par rapport à un autre, c'est qu'en supprimant le premier, on fait cesser le second.

Je n'insiste pas davantage ici sur ce principe de la méthode expérimentale, parce que plus tard j'aurai l'occasion d'y revenir en donnant des exemples particuliers qui développeront ma pensée. Je me résumerai en disant que l'expérimentateur doit toujours pousser son investigation jusqu'à la contreépreuve; sans cela le raisonnement expérimental ne serait pas complet. C'est la contre-épreuve qui prouve le déterminisme nécessaire des phénomènes, et en cela elle est seule capable de satisfaire la raison à laquelle, ainsi que nous l'avons dit, il faut toujours faire remonter le véritable critérium scientifique.

Le raisonnement expérimental, dont nous avons dans ce qui précède examiné les différents termes, se propose le même but dans toutes les sciences. L'expérimentateur veut arriver au déterminisme, c'est-à-dire qu'il cherche à rattacher à l'aide du raisonnement et de l'expérience, les phénomènes naturels à leurs conditions d'existence, ou autrement dit, à leurs causes prochaines. Il arrive par ce moyen à la loi qui lui permet de se rendre maître du phénomène. Toute la philosophie naturelle se résume en cela : Connaître la loi des phénomènes. Tout le problème expérimental se réduit à ceci : Prévoir et diriger les phénomènes. Mais ce double but ne peut être atteint dans les corps vivants que par certains principes spéciaux d'expérimentation qu'il nous reste à indiquer dans les chapitres qui vont suivre. contraexperiências. Logo, a única prova de que um fenômeno desempenha o papel de causa com relação a outro é quando se suprimindo o primeiro, se faz cessar o segundo.

Não vou insistir aqui ainda mais sobre este princípio do método experimental porque mais adiante terei a oportunidade de voltar a ele, dando exemplos particulares que desenvolverão minhas ideias. Resumirei dizendo que o experimentador deve sempre conduzir sua investigação até a contraprova; sem isso o raciocínio experimental não seria completo. É a contraprova que prova o determinismo necessário dos fenômenos e nisso ela é a única capaz de satisfazer a razão à qual, assim como dissemos, é sempre preciso fazer remontar o verdadeiro critério científico.

O raciocínio experimental, do qual examinamos anteriormente os diferentes termos, se propõe ao mesmo objetivo em todas as ciências. O experimentador quer chegar ao determinismo, isto é, ele procura ligar, com ajuda do raciocínio e da experiência, os fenômenos naturais às suas condições de existência ou, dizendo de outra forma, às suas causas futuras. Ele chega, por esse meio, à lei que lhe permite tornar-se mestre do fenômeno. Toda a filosofia natural se resume nisto: conhecer a lei dos fenômenos. Todo problema experimental se reduz a isto: prever e guiar os fenômenos. Mas este duplo objetivo não pode estar reunido nos corpos vivos senão por certos princípios especiais de experimentação que nos restam a indicar nos capítulos a seguir. 


\section{CONSIDERAÇÕES FINAIS}

Nosso sentimento nos leva a crer, desde o início, que devemos ter a verdade absoluta sob nosso domínio; mas, o estudo nos livra pouco a pouco dessas pretensões quiméricas. A ciência tem precisamente o privilégio de nos ensinar o que ignoramos, substituindo o sentimento pela razão e pela experiência, nos mostrando claramente o limite de nosso conhecimento. Mas, por uma maravilhosa compensação, à medida que a ciência assim rebaixa o nosso orgulho, ela aumenta nosso poder.

Claude Bernard

Apresentaremos aqui algumas reflexões sobre o percurso que realizamos, desde o projeto de pesquisa até a realização efetiva de nosso trabalho, retomando os aspectos principais desenvolvidos nesta dissertação. Procuraremos, em seguida, mostrar as possíveis contribuições que, a nosso ver, esse trabalho poderá trazer, tanto no âmbito acadêmico quanto fora dele, e finalizaremos propondo os desdobramentos possíveis para a pesquisa aqui iniciada.

Como dissemos, a motivação inicial deste trabalho surgiu do desejo de unir as formações em Francês e Biologia. Partimos da ideia de que uma forma de levar a cabo esse projeto seria através da realização da tradução de uma obra clássica de Biologia que, preferencialmente, não tivesse ainda sido contemplada com uma tradução para o português.

Chegamos ao nome do médico e fisiologista francês Claude Bernard e, após discussões com o Prof. Dr. Hamilton Haddad e a Profa. Dra. Maria Elice Brzezinski Prestes, pesquisadores ligados às áreas da Fisiologia e da História da Biologia, escolhemos traduzir seu livro Introduction à l'étude de la médecine expérimentale. Uma primeira observação que cabe aqui, em relação ao projeto inicialmente proposto, é a de que pretendíamos realizar a tradução do livro em sua íntegra, que consta de uma Introdução e três partes.

Ao longo do desenvolvimento do trabalho foi possível perceber que essa tarefa não poderia ser concluída na vigência de um projeto de mestrado, o que nos levou a trabalhar com a Introdução e a Primeira Parte (Do Raciocínio Experimental, constituído de dois capítulos: Da 
Observação e Da Experiência; Da Ideia a priori e Da Dúvida no Raciocínio Experimental), reservando a Parte Dois (Da Experimentação nos Seres Vivos) e a Parte Três (Aplicações do Método Experimental ao Estudo dos Fenômenos da Vida) para um futuro projeto, que poderá ser realizado em continuidade a este.

Esse livro foi escolhido pela sua abrangência, já que pode atingir um público mais amplo do que apenas os interessados no estudo da Medicina Experimental, pois é nele que aparecem pela primeira vez, sob a forma de reflexões do autor, as bases da área de estudo que surgiria a partir de então: a Fisiologia Experimental. Sua leitura interessa também a estudiosos da História da Biologia e a filósofos, devido às discussões nele contidas. Foi isso que motivou nossa escolha, apesar da existência de uma tradução para o português europeu.

Refletindo a esse respeito, percebemos que a sua tradução poderia ser uma forma de trazer para o público brasileiro uma tradução mais atualizada, uma vez que a tradução em português europeu foi realizada nos anos 1950. Além disso, propusemos uma tradução contendo notas explicativas, algo que não está presente naquela antiga tradução. Essas notas, em princípio, deveriam levantar aspectos relacionados à Biologia, explicando questões de conteúdo científico referentes a alterações ocorridas ao longo do tempo que separa a obra, escrita e publicada no século XIX, dos dias de hoje.

No entanto, uma vez iniciada a experiência de tradução, fomos percebendo que vários tipos de observações em forma de notas poderiam e/ou deveriam ser feitos; assim, elaboramos, ao longo do processo, quatro diferentes tipos de notas, que denominamos notas históricas, compreendendo fatos que refletem um dado momento da História da Biologia, notas explicativas, como um elemento facilitador para o leitor não familiarizado com termos de Biologia, notas atualizadoras, atualizando termos, e notas de tradução propriamente dita, mostrando as escolhas e opções adotadas. Essas notas foram pensadas para satisfazer, do ponto de vista histórico, o possível público leitor do século XXI, diferente daquele da obra original, e, do ponto de vista da ciência, diferentes leitores de diferentes áreas.

A escolha dessa obra foi pautada, como já ressaltamos, em sua importância histórica. Pretendemos, com essa tradução, confirmar por que razão o que foi ali exposto por seu autor 
teve um papel tão importante no desenvolvimento científico e continua a influenciar o pensamento científico até os dias de hoje. Julgamos que seria importante conservar a terminologia científica da época, bem como a forma peculiar de escrita científica praticada na época. Isso nos levou a optar por um tipo de tradução que privilegia o aspecto histórico da obra original, levando de alguma forma o leitor do século XXI ao contexto da obra no momento em que foi escrita, no século XIX.

Buscamos suporte teórico em obras que pudessem apoiar nossa opção e nas quais pudéssemos buscar embasamento para nossas reflexões sobre as escolhas feitas. Foi assim que escolhemos um procedimento de tradução denominado estrangeirizante (Venuti, 1995), pelo qual privilegiamos o estilo de escrita desse autor e a terminologia por ele utilizada e enfatizamos as questões científicas do século XIX por ele abordadas, da maneira como as mesmas se inseriam no contexto da época, em relação ao século XXI.

A tradução estrangeirizante proposta por Venuti se opõe ao que ele chama de tradução domesticadora, que traz o autor ao leitor. A ideia de que as traduções podem ser de dois tipos, a que leva o leitor ao autor ou a que leva o autor ao leitor, foi inicialmente proposta por Schleiermacher $(1813,2007)$, também desenvolvidas por Berman (1984), e foi a partir de suas ideias que Venuti acabou estabelecendo os termos que aqui utilizamos.

Ao longo dos capítulos desta dissertação, procuramos, em primeiro lugar, fazer um apanhando geral sobre a vida e obra de Claude Bernard, autor do livro que nos serviu de corpus, a fim de contextualizar a obra com a qual trabalhamos dentro do conteúdo geral do que foi produzido por esse cientista, tentando mostrar o que ele e sua obra representaram para o desenvolvimento dessa área do conhecimento.

Em seguida, nos capítulos subsequentes, procuramos levantar o histórico das ideias de tradução que contrapõem a tradução domesticadora à tradução estrangeirizante para que nossa opção de tradução pudesse ser compreendida. Em um passo seguinte, ainda em busca de suporte teórico para sustentar nossa estratégia de tradução, apresentamos de forma geral o que é Terminologia e o que se entende por Tradução científica ou especializada, uma vez que nosso trabalho também se insere nesse contexto. 
Finalmente, levantamos o que se entende por Tradução Comentada e como ela pode ser apresentada sob a forma de uma tradução acompanhada de notas, a fim de justificar nossas escolhas para o procedimento de tradução e para a apresentação dos resultados assim obtidos.

A realização deste trabalho de tradução foi extremamente prazerosa, levando a pesquisas e leituras bastante interessantes, as quais, infelizmente, não poderiam ser todas recuperadas e abordadas neste espaço. Várias frentes foram exploradas, tanto na área de Tradução quanto da História da Biologia, que prometem muitos desdobramentos, e que podem, sem dúvida, levar a muitos outros projetos. A quantidade enorme de dados que pôde ser acessada ofereceu um grande desafio, que foi o de limitar a pesquisa a apenas alguns poucos aspectos, entre todos os que puderam ser levantados. Mas, sem dúvida, esse desafio lançou as sementes de futuros estudos sobre esse autor e sua obra.

Esperamos que o trabalho que aqui apresentamos, resultado de nossas opções de tradução e de nossa escolha de conteúdo, possa ser útil para diversos tipos de leitores, não só aqueles interessados nos estudos da tradução, levantando questões sobre a tarefa de traduzir, mas também para professores e alunos interessados na História da Biologia ou até mesmo em questões de Filosofia.

Temos a certeza de que este projeto, acima de tudo, teve o importante papel de nos motivar a continuar levando adiante este trabalho, uma vez que pretendemos contemplar no futuro as traduções das Partes Dois e Três da mesma obra, nos mesmos moldes segundo os quais realizamos a tradução da Primeira Parte e da Introdução.

A pesquisa constante é uma porta que, uma vez aberta, nos convida sempre a prosseguir em busca de novas descobertas, como "espíritos raros", nas palavras de Claude Bernard (1865, 2008), quando afirmou que esses a quem ele assim chamou são aqueles poucos que conseguem pressentir as verdades novas, buscando-as em suas pesquisas, enquanto a maioria dos pesquisadores apenas desenvolve e persegue as ideias dessa minoria. Mas, ainda assim, ele enfatiza que tudo deve ser feito com modéstia, pois "o espírito verdadeiramente científico deveria nos tornar modestos e benevolentes. Na verdade, todos nós sabemos bem algumas poucas coisas e todos nós somos falíveis diante das dificuldades imensas que nos apresenta a 
investigação dos fenômenos naturais" (BERNARD. 1865, 2008, tradução nossa). É com esse espírito de busca de respostas que temos a motivação para continuar a beber da fonte que nos oferece esse pesquisador, que tantas contribuições trouxe ao entendimento do que pode ser a verdadeira busca do conhecimento. 


\section{REFERÊNCIAS BIBLIOGRÁFICAS}

AUBERT, F.H. Tradução técnico-científica e terminologia: um ensaio exploratório de uma via de mão dupla. TradTerm 7, p. 41-52, 2001.

BAKER, M. (ed.). Routledge Encyclopaedia of Translation Studies. London: Routledge, 2011.

BASSNETT, S. Estudos de Tradução. Fundamentos de uma disciplina. Tradução de Viviana de Pádua Figueiredo. Lisboa: Fundação Calouste Gulbenkian, 2003, p. 64-71.

BATALHA, M.C. e PONTES Jr., G. Tradução. Petrópolis: Editora Vozes, 2007.

BERGMANN, J.C.F. e LISBOA, M.F. A. Teoria e Prática da Tradução. Curitiba: Editora Ibpex, 2008.

BERMAN, A. A prova do estrangeiro. Tadução de Maria Emilia Pereira Chanut. Florianópolis: EDUSC, 2012.

. El albergue de lo lejano. Tradução Núria d’Asprer. Doletiana, 4 Filosofia i traducció, p. 1-10, 1985.

.L'épreuve de l'étranger. Paris : Gallimard, (1984) 2011.

BERNARD, C. Recherches anatomiques et physiologiques sur la corde du tympan, pour servir à I'histoire de l'hémiplégie faciale, Paris, Bourgogne et Martinet, 1843, 32 p.

. Leçons sur les propriétés physiologiques et les altérations pathologiques des liquides de l'organisme, Paris : Baillière, 1859, 2 vol.

. Introduction à l'étude de la médecine expérimentale. Paris : Édition Flammarion (2008) 1a ed., J. B. Baillière et fils, 1865.

Rapport sur les progrès et la marche de la physiologie générale en France. Paris Imprimerie impériale, 1867, 237 p.

. Leçons sur le phénomène de la vie communs aux animaux et aux végétaux. Paris :

J.B. Baillière et Fils, 1878-1879, 2vo. 
. Introdução à medicina experimental. Tradução de Maria José Marinho. Lisboa :

Guimarães Editores, 1959.

. Cahier de notes 1850-1860. Paris : Gallimard, 1965.

BOISSEAU, M. Présentation. Palimpsestos, 20, 2007. Disponível em: http://palimpsestes.revues.org/81

BRITTO, P.H. O tradutor como mediador cultural. Synergies Brésil, no spécial 2, p 135-141, 2010.

BUCHEZ, P.J.D. Introduction à l'étude des Sciences Médicales. Leçons Orales. Paris : V.Evéillard et Co Éditeurs, 1838.

CAPONI, G. Claude Bernard y los límites de la fisiología experimental. História, Ciências, SaúdeManguinhos, vol. VIII (2), p. 375-406, 2001.

CABRÉ, M. T. La Terminología: representación y comunicacíon. Elementos para uma teoria de base comunicativa y otros artículos. Barcelona: Institut Universitari de Linguistica Aplicada, Universitat Pompeu Fabra, 1999.

CAETANO, P.R.B. José Paulo Paes, leitor de Schleiermacher. TradTerm, v.22, pp. 173-187, 2013

CAMPBELL, N. A. Biology. The Benjamin/Cummings Publishing Company, 1996.

CORNELIS, G.C. Is Popularization of Science Possible? The Proceedings of the Twentieth World Congress of Philosophy. Boston: Boston University, 10-15 August. 1998. Disponível em https://www.bu.edu;wcp/Papers/Scie/ScieCorn.htm

CURTIS, H. e BARNES, N.S. Biology, New York, Worth Publishers, 1989.

DELISLE, J. e WOODSWORTH, J. (org.). Os tradutores na História. São Paulo: Ática, 1998.

DE REMUSAT, P. Les Sciences Naturelles - études sur leur histoire et sur leurs plus récents progrès. Paris: Miche Lévy-Frères, Librairies-Éditeurs, 1857.

DE ROMO, A.C.L. Claude Bernard, el hombre y el científico. AnMed(Mex), 52 (2), p. 90-96, 2007. 
DRAKE, R.L; VOGL, A. W. \& MITCHELL, A. W. M. Gray Anatomia para Estudantes. Elsevier Editora Ltda., 2012.

DUTRA, L.H de A. A Epistemologia de Claude Bernard. Campinas: Centro de Lógica, Epistemologia e História da Ciência- Unicamp, Coleção CLE, vol. 33, 2001.

. Claude Bernard e o determinismo mental. Natureza Humana vol.5, n.2, p.351-

391, 2003.

ESTEVES, L.M.R. Atos de Tradução. Éticas, intervenções, mediações. São Paulo: Humanitas, FAPESP, 2014.

- A popularização científica como uma forma de tradução. In: ESTEVES, L. e VERAS, V (org.) Vozes da Tradução. São Paulo: Humanitas, 2014, p.39-52.

FARKAS, A. La méthode expérimentale de Claude Bernard pour sortir de l'impasse génétique. Fusion, n.97, p. 8-22, 2003.

FERREIRA, A. B. de H. Novo Dicionário da Língua Portuguesa. Rio de Janeiro: Ed. Nova Fronteira, 1986, p. 1696.

FREITAS, L. F. Visibilidade problemática em Venuti. Cadernos de Tradução, v.2, n.12, p.55-63, 2003.

FURLAN, M. e ALTHOFF, G. Sobre traduções comentadas. Scientia Traductionis, n.7, p. 134-135, 2010.

GRMEK, M. Le Legs de Claude Bernard. Paris : Librairie Arthème Fayard, 1997.

GROSS, C.G. Claude Bernard and the constancy of the internal environment. The Neuroscientist, vol. 4, n. 5, p.380-385, 1998.

HADDAD, H. Uma Breve História da Fisiologia. In: Margarida de Mello Aires. (Org.). Fisiologia. 4 ed. Rio de Janeiro: Guanabara-Koogan, p. 1-35, 2012.

HALL, J. E. \& GUYTON, A. C. Tratado de Fisiologia Médica. Mississipi: Saunders Elsevier, 2011. 
HOUSSAY, B.A. La notion d'intégration et de stabilité des fonctions de l'organisme depuis Claude Bernard. In : WOLFF, E. et al. Philosophie et méthodologie scientifiques de Claude Bernard. Paris : Masson \& Cie, Éditeurs (1967)

JAKOBSON, R. (1959). Aspectos linguísticos da Tradução. In Linguística e Comunicação. São Paulo: Editora Cultrix, $24^{\circ}$ ed., 2007, p. 63 a 72.

JANCZUR, C.; ZAVAGLIA, A.; HADDAD, H.; PRESTES, M.E.B. Claude Bernard e a constância do "meio interno". Filosofia e História da Biologia. Vol.8, n.3, p.381-393, 2013.

JOLY, J.F. Prefácio. In: DELISLE, J. e WOODSWORTH, J. (Org.). Os tradutores na História. São Paulo: Ática, 1998.

KARAS, H. Le statut de la traduction dans les éditions bilíngues: de l'interprétation au commentaire. Palimpsestes, 20, 2007. Disponível em: http://palimpsestes.revues.org/100

KRIEGER, M. G. Relações entre Terminologia e Tradução. In: KRIEGER, M.G. e MACIEL, A.M.B. Temas de Terminologia. São Paulo: Humanitas, 2001, p.155-16.

. Do ensino da terminologia para tradutores: diretrizes básicas. Cadernos de

Tradução, v.1, n.17, 2006, p.189-206.

KRIEGER, M.G. e FINATTO, M.J.B. Introdução à Terminologia- teoria e prática. São Paulo: Contexto, 2004.

LAVILLE, C, e DIONNE, J. A construção do saber. Porto Alegre: Artmed ; Belo Horizonte: Editora UFMG, 1999.

MACHADO, C.A. As vozes ruidosas das traduções modernas do Tetrabiblos de Ptolomeu: um relato de experiência de tradução científica. In: ESTEVES, L. e VERAS, V (org.) Vozes da Tradução. São Paulo: Humanitas, 2014, p.237-256.

MARDUEL, M.A. Claude Bernard, um physiologiste natif du beaujolais- sa famille, sa vie, son oeuvre. Disponível em http://marduel.com/dossiers/claude-bernard.pdf Consultado em 21 de fevereiro de 2015.

MARTINS, M.A.P. As Contribuições de André Lefevere e Lawrence Venuti para a Teoria da Tradução Cadernos de Letras (UFRJ) n.27, 2010 
NGUYEN-SCHOENDORFF, O. Je suis.... Claude Bernard. Lyon: Jacques André éditeur, 2009.

OUSTINOFF, M. Tradução- História, teorias e métodos. São Paulo: Parábola, 2011.

PURVES, W.K., ORIANS, G.H. e HELLER, H.C. Life, The Science of Biology. Massachussets: Sinauer Associates Inc. and W.H. Freeman and Company, $4^{\text {th }}$ edition, 1995.

RAMOS, P. C. Interface Tradução Terminologia. In: KRIEGER, M.G e MACIEL, A.M.B. Temas de Terminologia. São Paulo: Humanitas, 2001: 164-170.

RANG, H.P; DALE. M. M.; RITTER, J.M.; HENDERSON, G. Farmacologia. Churchill Linvigstone Elsevier, 2012.

REY, L. Dicionário de Termos Técnicos de Medicina e Saúde. Rio de Janeiro: Guanabara Koogan, 1999.

RODRIGUES, C.C. Desafios ao Ensino da Tradução. Abehache, ano 2, n. 3, p. 13-24, 2012.

ROSTAND, J. Hommes de Vérité - Pasteur, Claude Bernard, Fontenelle, La Rochefoucauld. Paris: Librairie Stock, 1955.

. Hommes d'autrefois et d'aujourd'hui. Paris: Gallimard, 1966.

SARDIN, P. De la note du traducteur comme commentaire: entre texte, paratexte et pretexte. Palimpsestes, 20, 2007. Disponível em http://palimpsestes.revues.org/99

SALAMA-CARR, M., BATHGATE, R.H., DELISLE, J., FOZ, C., NANQIU, L., RAMAKRISHNA, S., WOLLIN, L. Os tradutores e a disseminação do conhecimento. In: DELISLE, Jean e WOODSWORTH, Judith (org.). Os tradutores na história. São Paulo: Ática, 1998.

SCHILLER, J. Claude Bernard et les problèmes scientifiques de son temps. Paris: Les Éditions du Cèdre, 1967.

SCHLEIERMACHER, F.E.D. Sobre diferentes métodos de traduzir. Princípios, v. 14, n. 21 (2007) Tradução de Celso Braida, do original de 1838 (Friedrich Schleiermacher'sammtliche Werke, Dritte Abteilung: Zur Philosophie, Zweiter Bd., Berlin, Reimer, 1838, p.207-245. 
SNELL-HORNBY, M. A “estrangeirização" de Venuti: o legado de Friedrich Schleiermacher aos Estudos da Tradução. Pandemonium, São Paulo, v.15, n.19, 2012, p. 185-212.

TREVISANI, A.P. Teoria e prática da tradução: o papel do tradutor. Maringá, v. 29, n. 1, p. 35-40, 2007.

SOARES, M. C. S. Manual de Redação Técnica e Científica. São José dos Campos : INPE.

Disponível em :

http://mtc-m19.sid.inpe.br/col/sid.inpe.br/mtc-m19/2011/12.12.11.52/doc/publicacao.pdf

VACHEROT, E. La métaphysique et la science ou Principes de Métaphysique Positive. Paris: Librairie de F. Chamerot, 1863.

VENUTI, L. Genealogies of Translation Theory: Schleiermacher. TTR : traduction, terminologie, rédaction, vol. 4, $\mathrm{n}^{\circ}$ 2, 1991, p. 125-150.

. The translator's Invisibility. London, New York: Routledge, 1995.

. Os escândalos da tradução- por uma ética da diferença. Tradução de Laureano Pelegrin, Lucinéia Marcelino Villela, Marileide Dias Esqueda, Valéria Biondo. Edusc, 2002.

VICENTINI, A., FERREIRA, A.M.A e PEIXOTO, E.R. Questões de Tradução. TradTerm, 14, p 177-192, 2008.

VIEIRA, R.M. Raízes históricas da medicina ocidental. Editora Fap-Unifesp, 2012.

WILLIANS, J. \& CHESTERMAN, A. The Map. A Beginner's Guide to Doing Research in Translation Studies. Manchester: St. Jerome Publishing, 2002.

YANG, Wenfen. Brief Study on Domestication and Foreignization in Translation. Journal of Language Teaching and Research, Vol. 1, No. 1, pp. 77-80, January 2010.

ZAVAGLIA, A., POPPI, C., MADRUGA, C., NASCIMENTO, A.C.C.S. Terminologia e Tradução: o caso dos textos literários. In: ALVES, I.M., DE JESUS, A.M.R., OLIVEIRA, L.P., PEREIRA, E.S. (Org.). Estudos lexicais em diferentes perspectivas. São Paulo: FFLCH/USP, 2010, v. 2, p. 17-34. 